(in

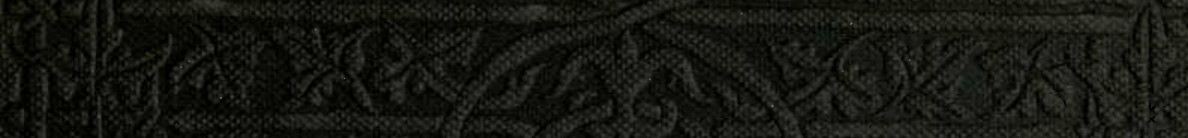

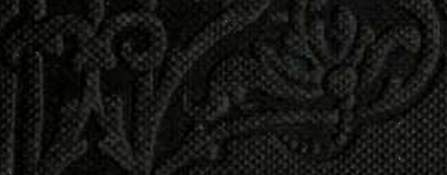

(1) 210

(1)

s.5

(3)

3)

翟然

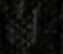

(1)

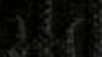

Sors

(1) 353

(1)

and

(3)

1.9.

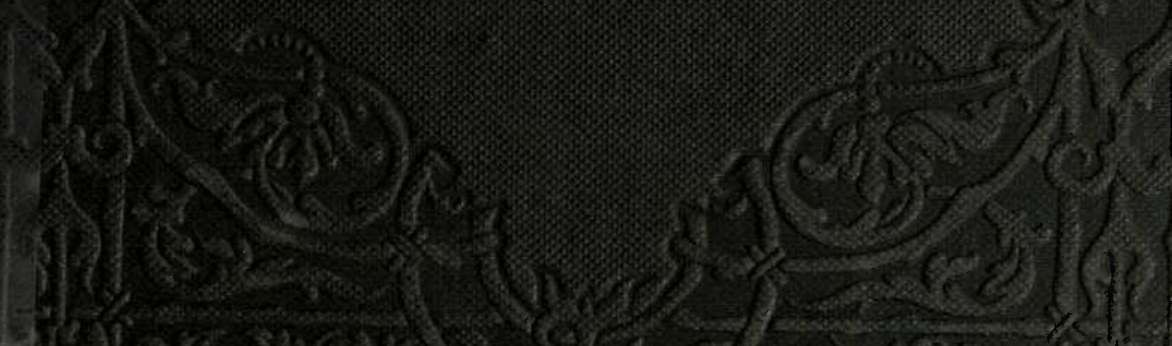

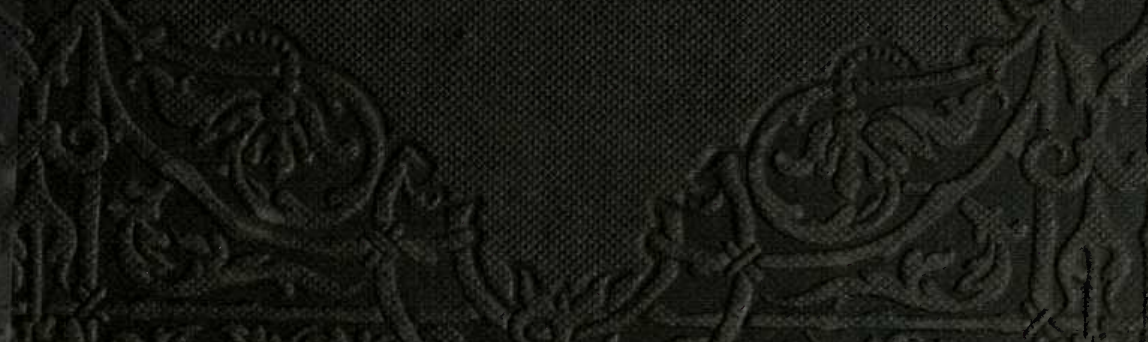

(a) 45

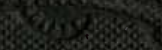

6. 6.

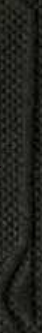

8 


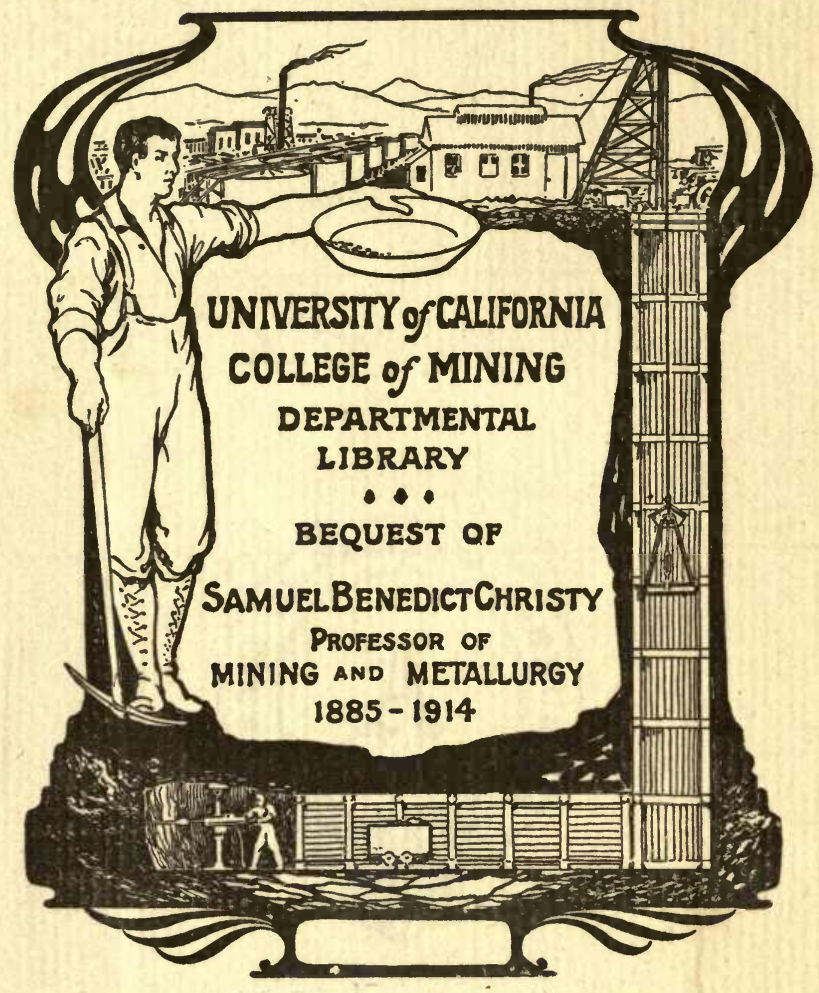


Samunc B. Phrmity,

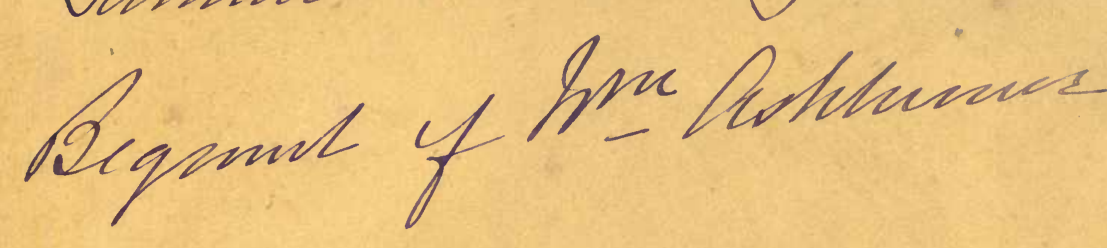





\section{AN \\ HISTORICAL INQUIRY}

INTO THE

\section{P R E C I O US M E T A L S.}


LONDON :

PRINTED BY THOMAS DAVISON, WHITEFRIARS, 


\title{
HISTORICAL INQUIRY
}

\author{
INTO THE
}

\section{PRODUCTION AND CONSUMPTION}

OF THE

\section{PRECIOUS METALS.}

BY WILLIAM JACOB, ESQ., F.R.S.

IN TWO VOLUMES.

VOL. II.

LONDON :

JOHN MURRAY, ALBEMARLE STREET. 
HG 265

$\mathrm{J}_{2}$

10.21

shindor oner.

V.2

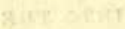

$2 x+253$

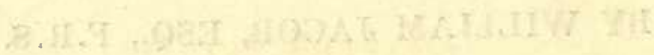

1

wockot

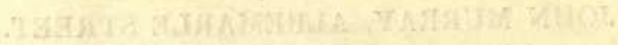




\title{
CONTENTS
}

\author{
or \\ VOL. II.
}

\section{CHAPTER XV.}

On the origin of the trade of the Lombards and goldsmiths, and on the influence of their operations on coined gold and silver.-Increase of commercial intercourse.-Adjustment of the relative values of coined money.-Rise of Lombards and goldsmiths.-Assay of plate.-Workmanship of plate.-Seniorage on gold and silver coins. -English gold coin little circulated.-Small quantity of it in Henry VII.'s reign

Page 1

\section{CHAPTER XVI.}

Of the commerce of Europe in the reign of Henry 7th as affecting the locality of the precious metals.-Gradual decrease of the precious metals till this time.-Laws directed against this.-The commerce of each country viewed as a guide to an estimate of the proportion of the precious metals each contained.-That of England.-Of France-Of Spain and Portugal.-Of Italy, and the flourishing state of its manufactures.-Germany.-The history of the Fuggers. - The northern states.-Effects of exchanges upon the quantity of gold.-Great use of it in utensils in Italy.-Comparatively small in Germany, France, and England.-Lord Leicester.-Cardinal Wolsey.-Duke of Northumberland.-Watches 


\section{CHAPTER XVII.}

On the acquisition of the precious metals from the discovery of America, in 1492, to the opening of the mines of $\mathrm{Po}$ tosi in 1546.-Small quantity of gold at first found in America.-The accumulation of years.-Humboldt's estimate rather too great.-The receipts from Mexico. -Those from Peru much larger.-The mines opened of both gold and silver and amount obtained.-Application of these metals to domestic purposes and religions uses

Page 41

\section{CHAPTER XVIII.}

On the acquisition of the precious metals from the opening the mines of Potosi, in 1546, to the end of the year 1599. -Discovery of Potosi.-Amount of its produce.-Humboldt's estimate.-Other mines of Peru.-Those of Chili. -Brazil gold-washings. - Mines of Europe._Estimate of the aggregate amount of the stock of gold and silver at the end of the 16th century.-Of its application to domestic uses in Europe and in Asia.-Of the quantity converted into coin

. 57

\section{CHAPTER XIX.}

On the rise of prices simultaneously with the increase of gold and silver in the first century after the discovery of America.-Advance of prices in England.-Comparison of those of 1480 and 1599.-Prices of corn during this time.-Laws relative to the export of corn.-Rise of rents noticed by Latimer.-Alteration in the value of coin and in the expenses of subsistence-Table of the advance of prices in France.-Alteration in those of Spain, Italy, and Germany 


\section{CHAPTER XX.}

Of the effect of the increase of metallic wealth on the various classes of society between 1483 and 1583.-General complaints of distress.-From the gentry, husbandmen, manufacturers, and merchants, from "A Briefe Conceipte touching the Commonweal of this Realme of England."Effects of the increase of prices.-In England, the crown becoming comparatively poorer, the landed proprietors and cultivators benefited as well as merchants and manufacturers.-The labourers injured.-The rise of the middle classes of society.-The effect of the first influx of gold and silver greater than that of larger quantities subsequently

- Page 87

\section{CHAPTER XXI.}

On the increase of metallic wealth and the proportionate increase of material wealth between the years 1600 and 1700.-Increase of produce from Potosi not large.-Severities exercised towards the natives.-Several new mines opened in Buenos Ayres.-Silver mine at Pasco very rich.-Those of quicksilver at Huancavelica much injured.-Gold-washings in Chili-The mines of New Granada or Columbia.-Of Choco.-Of Mexico.-Method of working them and their increased produce.Brazil.-Increase of the use of gold articles.-Of coined money.-Of population.-Of commodities and wealth generally.-Estimate of its amount $\quad$. 115

\section{CHAPTER XXII.}

On the production of gold and silver from the year 1700 to 1809 inclusive.-Mexico.-Its original state and method of government.-Increase of wealth.-Estimate of the 
increased productiveness of the mines.-Peru.-Its thinness of population and little advancement.-Columbia.Its gold and silver mines.-Chili-Buenos $\Lambda$ yres.-Contraband trade; gold furnished thereby.-The sum total of the whole produce of South America

Page 145

\section{CHAPTER XXIII.}

On the rate of loss on gold and silver coin by abrasion in remote and recent periods.-Increased rate of loss by abrasion.-Experiments at the mint on alloys and abrasion.Greater loss upon silver, and upon recent coinage.-The least upon British gold.-Recent experiments.-Calculation of the medium rate of loss on gold to the beginning of the 18th century.-Silver, loss on various pieces and its proportionate loss to gold.-General improvement in

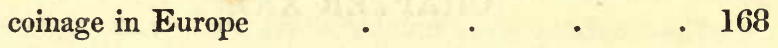

\section{CHAPTER XXIV.}

On the consumption of gold and silver and on the rate of prices of commodities from 1700 to 1810 . The stock of the precious metals in Europe in 1700.-Its dispersion by trade with India, China, America.-Its increased use in articles of luxury in England and France; for religious uses in Spain, Italy, Germany.-Increase of plate, spoons, watches.-Plating, gilding.-Trinkets.-Estimate of the amount, and that of coin.-Comparative prices of wheat with coin in England, Dantzic, Spain.-Of other articles.-Increase of material wealth and coin in England and in Europe generally $\quad$. $\quad$ • $\quad$. 192

\section{CHAPTER XXV.}

On the production of gold and silver from the end of the year 1809 to the end of 1829.-Decrease in the produce of 
the mines.-Mexico; its internal wars. - The mines of Guanaxuato, Zaccatecas, Sombrerete, their general decrease.-Mines of Tasco.-Inferiority of the coin.Amount coined. - Columbia, decrease of its gold washings. -Estimate of gold and silver coined.-Peru.-Its wars. -Wealth exported by exiles.-Amount of coined money. -Dilapidated state of mines.-Present state of those of Hialgayoc, Pasco, Callioma, Huantajaya, St. Rosa, and Layacota.-Estimate of the whole amount.-Buenos Ayres. -Its wars and rapid decline of produce in all its mines. - High rate of interest there.-Amount of dollars coined. -Chili._Mine at Huesco discovered in 1812.-Amount of gold produced.-Brasil.-Decrease of its' gold washings.-Future prospects.-Gold from North America.Estimate of the whole produce of America.-Gold from Hungary, Russia, and Asia.-Amount of it Page 225

\section{CHAPTER XXVI.}

On the consumption of gold and silver in the twenty years between 1810 and 1819 , but especially on the application of them to other purposes than coin.-Gold and silver manufactures in England.-In various towns.-Sweepwashers.-Refiners.-Quantity of gold refined.-Goldbeater's trade in London.-In the country.-Leaf-gold. -Gilt buttons.-Toys and trinkets.-Plating._-Gilded china.-Quantity of gold thus consumed.-Increased use of jewellery and gilt articles in every country.-London jewellers.-Fine gold.-Estimate of quantity consumed by them.-Silver goods.-Amount of duty paid.-On watches.-On plated goods.-Silver toys.-Estimate of the quantity annually consumed.-French jewellers.Gold and silver watches.-Quantity consumed estimated by Chaptal.-Consumption in Switzerland.-Bavaria.Austria.-Turkey.-Russia.-Prussia_-Large consump- 
tion in the Netherlands.-Spain.-Italy.-General estimate for Europe and America.-Quantity reproduced.Trade with India and China.-Estimate of the gold transmitted by this means.-By the trade with the Levant.General estimate of the quantity of coin; its diminution.

Page 270

\section{CHAPTER XXVII.}

Of the gold and silver of Africa and Asia.-African company. Quantity of gold imported by them.-General produce very small.-Eastern Africa.-Silver and gold from Turkey.-Arabia and Persia-Ava, Assam, Tibet, Cochin China.-East India Company.-Malay peninsula.-In China none of the precious metals coined.-Indian Islands.-Mines in Borneo.-Japan.-Estimate of the whole amount of gold and silver produced in Asia.-Of that coined.-Small quantity of coin required in China. - Chiefly silver.-Care taken of it.-Stationary prices. -Estimate of the quantity of the precious metals consumed for private use

324

\section{CHAPTER XXVIII.}

On the proportion which that gold and silver which is coined bears to that existing in other forms.-Consumption greater than the supply from the mines.-Consequent use and diminution of the stock of coin.-Proportion of coin to silver and gold in the possession of various classes of society.-Consideration of each.-Of the stock of jewellers.-Of that in the Bank of England.-Total proportion.-Estimate of proportion in France, the rest of Europe, and America.-Of the transfer of one stock into the other at various times 


\section{CHAPTER XXIX.}

On the prospect of future supplies of the precious metals. The decrease of capital and state of war operate against an increase in the produce of the mines.-Capital withdrawn from Spanish America.-Foreign capital required and carried there.-Thin population and scarcity of labourers.-Slavery.-Mines in Russia

Page 358

\section{CHAPTER XXX.}

On the amount of paper money.-On the decline of prices.Conclusion.-Review of previous calculation of current coin.-Paper money.-In Russia.-Its value.-Its depreciation in Austria.-Paper money in the remainder of Germany.-France.-England.-United States.-Slight variation of the metallic value of paper money generally. -Amount of the circulating medium generally and its diminution.-Effect in lowering prices.-Counter operation of other causes.-Difficulty of estimating the changes on any articles.-General view of those in the prices of the produce of the soil.-Effects of rise or fall of prices on society relatively considered . . . 365 


\section{ERRATUM.}

Page 214, in the running title, for circulation, read calculation. 


\section{A N I N Q U I R Y,}

ETC.

\section{CHAPTER XV.}

On the origin of the trade of the Lombards and goldsmiths; and on the influence of their operations on coined gold and silver.

THE naval power of England, if strictly speaking it did not commence with the reign of Henry VII., yet during that reign made a greater progress than at any former period. The foreign trade of the country, and especially the carrying on of that trade by English instead of foreign ships, kept pace with, or rather advanced before, the military marine power. The Hanse Towns, the Netherlands, Spain and Portugal, and the free States of Italy were partakers of this increase of commerce, and with England and France all united in forming an extensive body, with interests which, though united in their principal objects, were often opposed in detail. The mercantile people thus composed a kind of voluntary corporation through 
Europe, whose influence acted most powerfully on the knowledge, the morals, the manners, the governments, the laws, and the religion of the western world. Half a century from the commencement of the reign of that monarch, by a new way to India being opened, and by the discovery of America soon after, a new impulse was given to the commercial spirit and enterprise which has continued to increase, in spite of occasional interruptions, to the present day.

In this commercial intercourse, the several countries which produced more of any commodities than were needed for their own demand, would sell them to such as required them for consumption. But as one country wanted more of some other than that other could supply, or than it had equivalents to give in return to that particular country, the difference must be made up by payments in the commodity which is called money, or in something to represent that commodity which would become equally available in commerce. The difference in the weight, the purity, and the denomination of metal money in the several countries was very great; and the risk and expense of conveying it to a distance were still more powerfully opposing obstacles. Hence arose the invention of bills of exchange. The intricacy and complication of the several kinds of money current in the numerous trading states, such as the small republics of Italy, and the various in- 
dependent sovereignties of the Hanse Towns, caused the subject of exchanges to be a branch that required much science, much experience, and much study; and the more so as the several independent communities were constantly introducing new laws and regulations affecting the value of the coins which they respectively issued.

From the circumstances thus arising, in addition to the variety of languages used by the commercial people, the business of exchanges, which had originated in Italy in the latter end of the twelfth century, and had rapidly extended to the other countries, was confined to a few persons, from the district where the profession had originated, called Lombards; who by their skill, craft, wealth, and influence acted a most important part, not merely as the mediums of commercial intercourse between individuals, but in all the political transactions between the governments of the several communities, as well as in financial affairs between the rulers and their subjects.

In England and France and the other larger communities of Europe, a profession similar to that of the Lombards arose, which became necessary in all of the larger operations of domestic commerce. This was the trade of the goldsmiths, which at an early period had comprised not, as now, only the dealers in or makers of gold and silver articles, but also that trade which has since 
the separation of the two ancient branches received the name of bankers.

The trade of the goldsmiths consisted, in England, in exchanging the coins of foreign countries with those of their own. We can scarcely conceive in our time when, both in England and in France, all the current money is of a low but fixed value and of domestic coinage, of what importance this trade must have been, without bearing in mind that a grain of gold or of silver at the period now under consideration, the reign of Henry VII., was at least equal in value to seven or eight grains in the present day, whenever it was to be exchanged for corn, cloth, or any other commodity. Those who exercised that trade must have found it necessary to acquire such a knowledge of chemistry, and such facility in performing its operations, as could enable them to decide certainly and speedily on the exact portion of alloy which each piece contained, and its exact weight, to the minutest subdivision of weights, with the greatest accuracy.

The far greater part of the gold money and a large proportion of the silver money must have been too valuable to have come into common circulation. When a quarter of wheat was worth four or five shillings, he who purchased a bushel, or even a sack, would pay for it in copper, lead, or tin money. The same must have been the 
case of one who wanted beer when it was at three farthings the quart, or wine when it was two-pence the quart, or mutton when it was less than a penny the pound. Thus, Holinshed speaking of the poverty of the farmers about the year 1500, says, "If one of them did cast down his purse, and therein a noble, or six shillings in silver (for such men cared not for gold, because it was not so ready payment, and they were often enforced to give a penny for the exchange of an angel), it was very likely that all the rest could not lay down so much against it." At a time when, among a company of farmers, six shillings could scarcely be found, it cannot be supposed that the labourers, however employed, who were the most numerous class, could have occasion for coin of such value as even the silver pennies of that time.

Whatever coined money may have been in existence in that age, the far greater part of that composed of silver and a still greater proportion of that struck in gold, would rest in the hands of the Lombards and the goldsmiths and such other persons as had to transact the larger operations of buying and selling. The monarchs, too, who by their parsimony or their extortion were enabled to amass treasure, would retain a large share of the coined or uncoined precious metals; almost the whole of that retained by the Lombards would be the foreign coin. The goldsmiths would prefer 
the coin of the realm, which would thus form a principal part of their stock of money, whilst they would retain a large quantity of gold and silver in ingots or in articles of furniture or of ornaments. The monarchs, as also the prelates and nobles who were rich, would be as likely to retain the domestic coin or utensils of the precious metals as any of the foreign coined money. 'This distribution would be caused by the state of the laws then in existence. No tax was then as now levied on manufactured plate, but all articles made of gold and silver were to be of the same degree of purity as the coin of the realm.

Whatever was manufactured in London or in some of the larger places was ordered to be assayed and stamped by the warders of the craft in such town; but whatever was made in places " where no touch was ordained" was to be stamped by the maker, and if found beneath the proper standard, it was confiscated to the crown ${ }^{1}$. In this state of affairs any article of plate would be of the same value, in equal weights, as gold or silver in ingots; and hence as occasion might require, the vessels being worth no more than their weight, would be on every pressing emergency readily converted into coin. The workmanship of plate would in that age cost but little, as luxury had not reached the point in that kind of art which it soon after-

'Bills of Parliament, second Henry VI. cap. 12 and 13. 
wards attained in the hands of Benvenuto Cellini at Florence and of his successors in the other parts of Europe. The taste displayed in the forms and the decorations of gold and silver utensils was very coarse both in France and in England. Voltaire, in his General History, says, " the work of the goldsmiths in Paris was so bad that the king (Louis 12th) in 1501 forbade the manufacture, so that the French had their plate from Italy." There seems good reason to believe that the English of that period did not excel the French artizans in the fabrication of gold and silver articles. We may thus account for what we find often stated in the records of the age, that the religious houses, the nobility, and rich individuals, gave up to the monarch on pressing emergencies their plate for the public service. Such a surrender in the present day, when a heavy tax and the workmanship of artists make plate of silver of more than double its value in weight ${ }^{1}$, would be deemed a most oppressive requisition, whereas, at the period referred to, the difference between making payments in coined money or in manufactured gold and silver would amount but to a trifle.

In the reign of Henry VII., and in the pre-

${ }^{1}$ It has been commonly reported that a service of plate presented as a grateful memorial from Portugal to the Duke of Wellington had cost about eighty-five thousand pounds for the metals and eighty-six thousand for the workmanship. 
ceding period in which gold money had been coined in England, there was a reluctance to take it among the internal traders. This arose from the practice of the monarch to take a seniorage on that coin as well as on the silver. The amount of this was well known to the Lombards and goldsmiths; and as the foreign gold coin; among that class, passed from hand to hand at a value fixed by the weight of the pure gold it contained, and the English gold passed at the legal value, which was increased by the seniorage, it was the interest of those two descriptions of traders to secure what rested in their own hands in foreign rather than in English gold. It would be more useful to the Lombards in their foreign negotiations, and to the goldsmiths in the manufacturing branch of their trade.

We may in this way account for the very small amount of gold coinage in England between the year when it commenced and the reign of Henry VII.; it being at scarcely the rate of three thousand pounds yearly. This seniorage, however, prevented the application of the domestic coined gold to any other purpose than that of money, which probably was one of the inducements which had caused the practice.

Ruding has exercised his accustomed laborious diligence on this as on every subject relating to the coins of this kingdom, but with so little success, that he honestly confesses "that no very 
certain conclusions can be drawn from the amount of this deduction at any one time, as the rate of the seniorage seems to have been ever unsettled, and to have depended on the caprice, the avarice, or the necessities of the sovereign ${ }^{1}$." It appears, however, by the accounts he has collected (chiefly from the Lansdowne manuscripts in the British Museum), that in one period of the reign of Edward IV. a troy pound weight of gold, which was coined into nominal money amounting to twenty pounds sixteen shillings and eight-pence, had cost to the merchant for the gold, eighteen pounds six shillings and eight-pence; to the master of the mint, for coining, two shillings and four-pence ; thus leaving for seniorage two pounds seven shillings and eight-pence, or more than thirteen per cent. In the thirty-seventh year of Henry VIII. the troy pound of gold was coined into thirty pounds of legal money of the day. The cost of the gold to the merchant had been twenty-four pounds eighteen shillings, thus leaving for the fabrication and the seniorage five pounds two shillings, or a profit of more than sixteen per cent. These two instances of exorbitant seniorage are the exceptions to the general practice; as in no other years did it reach the same extent, though in a few they approached to it. On the average of the period from the eighteenth of

1 Ruding, vol. i. p. 180. 
Edward III. to the fourth of Edward VI. the seniorage, with a few high exceptions, seems to have amounted to between three and four per cent.

The seniorage on silver never seems to have attained the monstrous height to which that on gold had been carried in some few instances. It was, however, raised or lowered according to the state of the monarch's finances, or of his appetite or power for grasping the wealth of his subjects.

It is remarked by a noble writer, that " the profits of the seniorage were so much considered by our monarchs as a certain branch of their revenue, that they were occasionally granted in whole or in part, either to corporate bodies for their advantage, or for defraying certain charges expressed in the grant itself. They were sometimes granted to individuals by way of pension. And when the right of seniorage was extinguished in this kingdom, by act 18 Charles II. cap. 5, there was a pension, payable out of the profits derived from it, granted under the great seal for twenty-one years to dame Barbara Villiers of twopence by tale out of every pound weight of silver coin made at the English mint; which the legislature, out of a principle of justice, ordered to be continued out of the coinage duties imposed by that act ${ }^{1} . "$

'Lord Liverpool's letter to the king, p. 104. 
This seniorage upon the coin must have operated as an impediment to its general, and consequently its extensive, circulation; but a greater impediment still must have been encountered from the uncertainty of the amount of that seniorage, which varied, and that to a great extent, in a short space of time. It has been before stated that in one of the years of the reign of Edward IV, the seniorage on gold coins amounted to thirteen per cent.; in the next year, it amounted to six per cent.; and three years later, to only four per cent. In the thirty-seventh year of Henry VIII. the seniorage was more than sixteen per cent.; in the thirty-sixth year of the same reign, it was only eight per cent.; and in the thirty-fourth year, not more than three per cent. As the pieces of the same reign bore the same stamp, they would circulate among those of the inferior, but not the lowest, class of traders before their difference in value would be detected; but if presented to the goldsmiths or the Lombards, the discovery of the inferior value would be made, and the loss fall on those least prepared to bear it.

The great traders in money had modes of making their payments and settling their balances among themselves without reference to the legal value of the coins, but according to their value in their weight in pure gold or silver. If they paid or received the English coin at less than its legal value, they were. liable to heavy penalties; and they unwillingly, 
therefore, embarrassed their transactions by passing them even among themselves. The lesser traders also were taught by their losses to avoid, as far as they could, the English gold coin. This disinclination towards that description of-money continued strong till the reign of Elizabeth, when a great and general improvement in the currency of the kingdom took place. It had not, however, wholly disappeared so late as 1774 , when the great recoinage under George III. was effected; for before that operation, when the guineas by friction, by sweating, and by filing, had been greatly reduced in weight, the moidores of Portugal, which passed at twenty-seven shillings, were as general and were more preferred in all the western counties of England than the national gold coin, which, though a legal tender, had been generally very much diminished in weight.

As the great dealers in money thus avoided that coined in England, and rather chose to circulate that of foreign fabrication, it does not appear surprising that at a time like the reign of Henry VII., when England had rapidly increased in wealth, the amount of its own coin of gold and silver should have been so small, as it must necessarily have been if all that had issued from its mints in two preceding centuries had been then actually in circulation.

Notwithstanding the small amount of domestic coin, there must have been money to a large 
amount, and most certainly to a much larger one in foreign than in English coin. The riches of the kingdom increased during the reign of Henry VII.

It is, indeed, true that the greater part of this metallic treasure did not remain in the hands of his subjects sufficiently long to become as productive as it might have been made, but was extorted from them by the monarch by a variety of legal and illegal oppressions, and served to fill that treasury which was found amply stored at his death. The exact amount of that treasure it is difficult to determine: Coke states it at upwards of five millions, Sir Robert Cotton at four millions and a half; but the more probable estimate is that of Bacon, which Hume has adopted, one million eight hundred thousand pounds, being equivalent to near three millions of our present money; a sum probably much greater than that in the possession of all his subjects, and yet no more than his son and successor was enabled to dissipate in a few years; till at length he was compelled by his extravagance to have recourse to the plunder of the church, and to the debasement of the coin, to defray the expenses of his government. 


\section{CHAPTER XVI.}

Of the commerce of Europe in the reign of Henry VII., as affecting the locality of the precious metals.

The reign of Henry VII. in England, in which the first discovery of America was made, is a period of peculiar importance to the subject of this inquiry, as it was that from which the circumstances of the precious metals began to experience a vast change. Up to that period the decrease in the existing quantity had been proceeding during several centuries, and immediately after, an increase began which has continued without any interruption, though with much variation, to our own time. It would be desirable, if it were attainable, to know the quantity, or nearly the quantity, of those metals existing in the form of coins, and that in the shape of utensils, or of bullion; but as that knowledge cannot be obtained, it may be desirable to attempt some mode of estimation, which at least may have a plausible approximation to truth.

It was supposed that the stock of gold and silver could be increased by compulsory laws, and it was therefore by acts of the legislature, both of England and Scotland, decreed that all merchants, 
foreigners as well as natives, should import a certain quantity of coin or bullion in every ship in proportion to the value of the other goods, and should expend all that coin and bullion, with all the money received for their imports, in purchasing the commodities of the country; but they were forbidden to export any gold or silver, in coin or bullion, under very severe penalties. We need scarcely remark that these laws were found in practice so injudicious, and so incapable of being executed, that they were, in a few years, repealed in both countries.

During the whole of this reign the trade had increased both in its imports and its exports; and as the latter regularly exceeded the former, a great increase in the deposit of the precious metals either in the form of coin or of bullion must have taken place in this kingdom. There seems good reason to conclude that in proportion to the extent and population, those metals must have been more abundant in the British Islands than in any of the larger kingdoms of Europe. The state of the general commerce of the countries of the world, though an uncertain is perhaps the best criterion by which to form a judgment of the actual deposit of the precious metals in each individual country. That country which from its labour and soil produces the most valuable commodities, will receive in exchange for them the greatest portion of other articles. As gold and 
silver are merely commodities, it may be assumed that the greatest portion of them will be found in some form or other, and chiefly in that of utensils and ornaments, in those countries which have the most intercourse by trade with foreign countries. In this view it may serve a useful purpose to take a slight survey of the commerce of the several kingdoms of Europe at the close of the fifteenth century, as a guide to the estimation of the portions of the precious metals which they severally possessed.

Attention is first naturally invited to the state of commerce in our own country. Amidst the intestine wars between the houses of York and Lancaster, though tillage had been lessened and cultivation neglected, there had been a constant intercourse kept up with the other countries of Europe, but it had been chiefly conducted by means of foreign shipping. When Henry VII. succeeded to the throne, after conciliating the domestic factions, his attention was directed to the commerce of his dominions. One of his first steps was to secure free access to his ports for foreign merchants, especially the Italians, and to protect their persons and property in his dominions. This soon produced imports of various manufactured goods from that country, as well as the richer commodities of the East, which were paid for with the wool, cloths, lead, tin, and other productions of England. He entered into commercial treaties with other powers, and lessened 
the duties, by which the revenue, instead of declining, was improved from the larger quantity of the imports, whilst the domestic products given in exchange for such imports were raised in price.

The attention of this monarch was particularly directed to the increase of the ships and sailors of his kingdoms, and in this reign we find the rudiments of that celebrated navigation act, afterwards passed, to which the naval superiority of England has been commonly attributed. By the law 14 Henry VII. cap. 10, it was enacted that no wines of Gascony or of Guienne, nor the woads of Thoulouse, should be imported into England, except in ships belonging to the king, or in English, Irish, or Welsh ships navigated by seamen of those nations. This gave great encouragement to the constructing of ships, and caused the education of a considerable number of seamen.

The cloths made in England were bought up by the Steelyard company in an unfinished state, and sent to Flanders to be dyed, dressed, and finished; but Henry encouraged the perfecting the cloths of his own kingdom, and is said to have furnished capital for that and other purposes, and even to have become a partner, and to have drawn gain from mixing in such operations; as he also appears to have done to a greater extent by the practice which he pursued through his whole reign of employing his ships in trading voyages or hiring them to the merchants on freight. 
From the little attention which had been paid to the general principles which regulate the commerce of nations, it is not wonderful that some impolitic or impracticable enactments should have been framed in that age.

France at the period we are surveying had been released from the rule of Louis XI., whose reign had been marked by cruelty, craft, and avarice, and whose objects had been much more directed to extend his power than to enrich his subjects. The sceptre was in the hands of a minor, who exhausted the treasure accumulated by his father. Among other acts of his reign he paid to our Henry VII. a kind of ransom of seven hundred and forty-five thousand crowns to withdraw from his invasion of France, and agreed to pay twentyfive thousand crowns annually to England for ever. By this and an unfortunate invasion of Italy he dissipated his treasure and oppressed his subjects. Though Louis had laid the foundation of a union of all the provinces of France under one head, his projects had not yet fully succeeded, and the territory was still divided into small and hostile sovereignties. It had few manufactures and little surplus produce. What foreign commodities were needed were supplied either from the Low Countries; from the cities of Italy, which dispensed the luxuries of the east; from Upper Italy, which furnished their raw silk; or from England, which supplied a portion of the 
wool with which the inhabitants were clothed. The wine of France, the chief article of its export, was so low in price that the balance of trade with most parts of Europe, the only division of the world with which that kingdom exchanged commodities, must have been against that country and been paid in the precious metals. These considerations, with the complaints to be found of the scarcity of money in all French writers who describe the period, and the high rate of interest paid on loans of money ${ }^{1}$, lead to the conclusion that the quantity of gold and silver actually existing in France was far less than was retained in our insular kingdom.

Spain and Portugal had, from the time when the whole possessions of the Moors had been contracted within the boundaries of the small but fruitful kingdom of Granada, been gradually declining from that wealth and splendour which the Mahomedans had displayed as long as Cordova was the capital of their dominions. The struggles which attended the long contests in the peninsula, till their final termination in favour of the Christians under Ferdinand and Isabella, were not favourable to the national industry; and the mines of silver which the Moors at earlier periods had worked in their kingdoms of Jaen and Seville, had

1 Philip IV. fixed the rate of interest to be exacted in the fairs of Champagne at twenty per cent., whilst in Italy the rate was at sixteen per cent. per annum, and in England one per cent. per month. 
been either exhausted or suspended; whilst the sands of the Darro, the Tagus, and the other streams, which formerly furnished some gold, had ceased to be productive. The commerce of the peninsula, which had flourished whilst the Moors had the sole possession and could maintain an intercourse with their brethren in faith in Africa and Asia, became contracted as their dominion had been lessened, and for two centuries had been confined to the exchange of a few commodities, which were of too similar a nature to be very ex-. tensive, between their chief trading city Malaga and the territories of Africa on the coast of Barbary.

It must be obvious from the circumstances of the two countries, that neither France nor Spain were likely to possess so much metallic treasure in the period we are viewing as at that time existed in England. It must be a matter of doubt rather than of certainty, if the stock of both countries united amounted to as much.

Italy had been long increasing in wealth of every kind, and though a few cities only are commonly spoken of in history, yet it is not possible that their affluence should not have extended to the other parts of the peninsula, and have stocked the smaller cities and towns with a larger proportion of the gold and silver of the world than was to be found in desolated France, in agitated Spain, or in England, where the contests of the two Roses had produced some degree of desolation and a 
neglected state of cultivation. The riches of Italy had been long and gradually increasing; the foundation was laid immediately after the destruction of the kingdom of the Lombards, by the fisheries carried on upon the shores of the Adriatic. From the art acquired by that profession, the Italians became the chief and most expert navigators ${ }^{1}$. They then opened a commercial intercourse with the rising dominions of the new Arabian prophet, which increased their wealth and extended their naval power. In a few centuries, when a kind of spiritual insanity was kindled in western Europe, and vast forces were to. be transported to the shores of Asia, the ships of the Italian cities were hired at enormous freights by the soldiers of the cross, who expended the savings of centuries in expeditions the pecuniary profit of which centred almost wholly among the merchants of the republics in the Italian peninsula. Commerce was naturally connected with, and in that age dependent on, navigation. The intercourse of Italy with Greece and with the Arabs, and, through the latter, with India, made the cities of Italy the depositories and the dispensers

1 Though the honour of the discovery of the mariner's compass has been contended for on behalf of several individuals, it seems probable that the world is indebted for it to an Italian named Flavio de Gioca, of Amalfi, who constructed the first with only eight points, but that afterwards the instrument received various and gradual improvements in other countries and from other persons,-Anderson's Hist. Comm. vol. v. p. 144. 
of the valuable products of Asia to the European world. The incenses, the perfumes, the spices, and the precious stones, were sources of vast gains ; whilst the profit of freights on the bulky commodities with which Europe supplied Asia added to the growth of the shipping branch of industry.

Under the auspices and the influence of this foreign trade, manufactures arose and flourished in all the districts of the peninsula. Milan supplied the best and most costly weapons and armour; Venice produced the most elegant plate, jewellery, and other ornaments; Genoa and Bologna furnished the richest silks, satins, velvets, and embroidery.

Many inventions which owe their origin to Italy and to this period contributed both to the fame and the wealth of that peninsula. Glasses for reading, in some measure resembling spectacles, had been invented by Spino, a Dominican monk of Pisa. Faenza fabricated within its walls a kind of earthenware or porcelain. Glass had been made by the Venetians to some extent, and mirrors had been introduced by that state, from whence clocks and watches had first became known. The manufacture of paper from pounded rags was an invention first practised in Padua. To these may be added the substitution of candles and tapers in the place of the lamps which had formerly been used.

This flourishing condition of navigation and commerce, both external and internal, led to the 
discovery, or rather the resource, of trading in money, or what afterwards obtained the name of banking. Assuming the denomination of the country in which it had originated, or, to speak more correctly, had been revived, the Lombards of Italy formed establishments in the trading cities of all other countries; and, as the channels through which all the transactions in the precious metals, and their substitutes, bills of exchange, were conducted, such great profits accrued, and such great fortunes were accumulated by the apparently small charges for brokerage, commissions, and exchanges, as made the most powerful monarchs of the age dependent on the Lombards for pecuniary assistance.

We are thus warranted in assuming, that as the greater part of the precious metals must of necessity remain in the country which is the most rich in its stock of general commodities, the greatest portion of those metals which Europe contained would be stored in the Italian peninsula.

In the age to which we now look, the empire of Germany, with the territories which have since been amalgamated with it, comprehending Bohemia, Prussia, and Hungary, furnished the little gold and silver which kept up the general stock of the European world.

Those countries, under a rigid feudal system, were divided into various independent and petty sovereignties, all jealous of their neighbours, and frequently embroiled with them. The roads and 
rivers were insecure, and the protection either to property or persons passing along them dependent upon the interest, the caprice, or the cupidity of the various princes or nobles who ruled the several minor dominions. In such a state of society the precious metals, which were obtained by the labour of the vassals, might for a time be kept in security within the walls of the castles of noble or princely robbers, but little of it would circulate in countries where no protection was afforded to intercourse, and where commerce was consequently almost unknown. In the keeps of the castles it would be useless to the owners, and equivalents would be sought for which would either secure and extend the power of its possessors, or serve to display their pomp and luxury in the exhibitions of those tournaments which were the chief theatre for displaying the power and the wealth of those petty sovereigns. The wants which such exhibitions required were not supplied by domestic labour. The arms and the decorations of the knights, the dresses and the ornaments of the high-born ladies, who by their presence gave splendour and excitement to such assemblages, were the products of other countries, for which none of their own territories yielded any equi. valents but silver and gold. Those metals would, therefore, be naturally exchanged for the costly armour of Milan, for the rich silks and velvets of Bologna and Genoa, for the trinkets of Venice, 
and for the perfumes, the spices, and the jewels of Asia.

From the various circumstances connected with Germany internally, from its possessing no foreign trade or navigation, and from the prices of all articles of the first necessity being lower there than in France and England, which have before been noticed ${ }^{1}$, it does not seem probable, that the gold and silver resting in Germany and in the countries combined with it in this view, could have been so great as in England, if it even equalled that in France and Spain.

History has indeed furnished us with the annals of a German family, the Fuggers, whose wealth, splendour, and finally honours, would raise our ideas of the commerce of that country to an extraordinary height. As illustrating the character of the age, it may not be out of place shortly to trace a family whose exertions had great influence, not only on the general commerce of the period in which they grew up, but more especially on the mining operations of various parts of the world. This family, now a princely house, traces its origin as far back as the year 1370, when the founder of it, who had inherited a small manufactory of linen cloth in a village near Augsburg, began to extend his trade, and continued it with such success that on his death, in 14.09, he left

${ }^{1}$ Vol. i. p. 317. 
a capital, then deemed enormous for a trader, amounting to three thousand gulden ${ }^{1}$.

His descendants were skilful, industrious, economical, and upright, and they in the course of a few generations established banking, mercantile, and mining transactions through almost every part of the continent of Europe. They served the house of Austria, and contributed more to its exaltation than all the nobility of their dominions. The Emperor Maximilian drew large pecuniary assistance from them on the security of the earldom of Kerchberg and the barony of Weisenhorn, which were mortgaged for seventy thousand guldens. They were enabled, in 1509, at two months' notice, to furnish the emperor with one hundred and seventy thousand ducats, on the security of Pope Julius II. and of the kings of France and Spain, and thus enabled that prince to put his army in motion against the republic of Venice.

At the assembling of the States of Germany in 1530, the emperor, Charles V., lived in the magnificent house of Anthony Fugger in Augsburg, and that lofty Spaniard allowed his host access to him at all times. By the pecuniary aid of him and his brother, Charles was enabled to equip that expedition against Algiers which terminated

1 There was in that age a gold coin denominated lubische gulden, and worth about seven shillings and sixpence in money of the present day; after 1535 they were scarce, and worth only two shillings. 
so unfortunately. It is related of this Anthony that on the return of the emperor from his expedition to the African shore, a fire of cinnamon, much more costly then than in the present day, was kindled in the apartment prepared for him, into which the host, in acknowledgment of the honour of the visit, threw all the bills, bonds, and other securities, which he held for money advanced to his imperial guest. This man is reported to have died possessed of six million golden crowns in ready money, besides estates, jewels, and goods in every part of Europe and in both the Indies.

When Charles V. was in Paris, and had surveyed all the wealth of the royal treasury, and the collection of rarities assembled in that capital, he declared that " he had one linen weaver in Augsburg who had money more than sufficient to pay for the whole of the valuables he had seen."

In the "Spiegel der Ehren," the splendour of the furniture, the magnificence of the palaces, and, above all, the unbounded charity of this family is recorded and most lavishly praised; and it is affirmed of the successors of the twelve children which Anthony left, that they had so branched out in the year 1619, as to number "forty-seven counts and countesses, and as many children as there are days in the year; and thus the blessings of Heaven rested visibly on their succeeding generations." 
One branch of this family has been already noticed in this inquiry ${ }^{1}$, which was settled in Spain. Another branch at Antwerp lent to our Henry VIII., after he had dissipated the treasure bequeathed by his father, one hundred and fifty-two thousand pounds; and to Edward VI., when the coinage in his reign was reformed, one hundred and twenty-nine thousand Caroline florins. There are notices also of the same family in Genoa, Milan, and Ghent. Their commerce was still continued, and seems not to have been held derogatory to the rank of nobility, or even that of sovereignty which they had attained. They are said to have purchased, within ninety years, two entire earldoms, six baronies, and fifty-seven manors, which were possessed among them as late as 1762 , besides houses and lands of great value in and around the city of Augsburg.

The two principal branches of the house still exist among the ranks of the mediatised princes of Germany. Though now distinguished by some privileges among the subjects of Bavaria and Wirtemburg, they are without political power; but their estates are said to comprehend twenty-one German square miles, or near three hundred thousand English acres, and to be peopled with forty thousand inhabitants, chicfly dependent on the cultivation of their lands. 
The wealth of the family we have here traced was but in a small degree collected from their transactions in Germany. That country was too poor to have contributed largely to it. Their prosperity must have been created more by the operations in Italy, in the Netherlands, and in Spain, than by those within the poor and feudal territory comprehended within the Germanic empire. The metallic wealth which the family possessed would, like the other commodities which composed their property, be in the countries wherein their commercial, or mining, or agricultural establishments were carried on, and in a proportion determined by the relative extent of such establishments, and not by the division of Europe, from which the family at the head of them had originally sprung.

It can scarcely be supposed that any considerable quantity of the precious metals, either in the form of coin, of ornaments, or of utensils, was to be found in the northern divisions of Europe at the period now under our review. The riches displayed by Canute, to which we have in a former part of this inquiry adverted, had been collected at a time when their sea kings had risen to naval power from the almost exclusive possession of the fisheries. With their barks which, though feeble, were superior to those of the rest of the world, they were seduced by their superior skill in navigation first to plunder other countries, 
and then to take permanent possession of favoured spots in them, till, in a short space of time, they became the settled owners and princes in England, Scotland, France, and the distant country of Naples.

The loss of the most enterprising and energetic portions of these northern people, with the cotemporaneous rise of the Hanse Towns, and afterwards the Dutch, who became their successful competitors in the fisheries, seems to have produced a general depression in the state of Denmark, Norway, and Sweden, which left them a prey to such internal feuds and hostilities, as had been avoided during the excitement which the preparation for offensive operations against the southern kingdoms had created. It is not necessary to enter into the relation of the petty, but harassing, warfare which was carried on by these kingdoms against each other, or the internal contests which existed in each. They were, for a period, diminished during the reign of Margaret of Denmark, who was raised to the throne in 1385, and ruled, during thirty-six years, the three kingdoms of Scandinavia, acquiring the name of the Semiramis of the north. After the death of that heroine, those three kingdoms became again separate sovereignties. They were commonly at war with each other; whilst the rising state of Lubec, by its wealth and its naval forces, acted, as suited best its commercial purposes, the 
part of a mediator, or an ally to the contending kingdoms. At the conclusion of the fifteenth century, these nations, having before been deprived of their fisheries, saw, amidst their internal commotions, their commercial navy transferred to the rising independent cities of Lubec, Wismar, Rostock, Stettin, Stralsund, and Dantzick, and their military naval force, if not annihilated, was far inferior to that of the confederacy of the Hanse Towns, in their immediate vicinity.

In this condition, when the mines of silver, if they had been at all worked, yielded but a trifling product, and none but minute particles of gold could be collected from the streams by so thinly spread a population; whatever may have been the quantity of the precious metals existing in Europe, we can look but for a very small portion of them in these northern kingdoms. The chief product of Norway, its timber, was conveyed to Holland by Lubec or Dutch ships, and to England and Scotland by ships of those nations. The value of timber depends chiefly on the freight, and the amount beyond that charge, small as it must have been, would be needed to pay for the scanty supply of corn which those countries regularly required.

The view here taken of the state of commerce in Europe, about the period of the discovery of America, tends to show that for the purpose of conducting such a trade a very small portion of 
the precious metals could have been required. The amount of the articles imported from and exported to foreign countries was small, when compared with that of subsequent ages, and the Lombards, by their operations in exchanges, 'would tend to lessen the demand for metallic money. The operations of the Lombards of that day had not received such extensive developments as they have since assumed, but as far as they did proceed, they tended to centralise payments and to draw them to a focal point in the large ciries where there were bourses or exchanges in which bills on one country could, by sale and indorsement, be exchanged for those on others.

Antwerp was the chief place for these kinds of exchanges in the north, and Genoa in the south of Europe. A Hollander might sell his salted fish to an Italian, and send his bill for the amount to Antwerp. A Londoner might sell wool to Flanders, and a bill for the amount to the same place, where it might be exchanged for the Hollander's bill, and payment with it made in Italy for the India or other goods which the Londoner had purchased at the trading cities in that country. By such an operation the demand for metallic money would be vastly less than it would have been if the Englishman had sent money to Italy for the India goods, and the Brabanter money to England for his wool, and if the Dutchman, in- 
stead of taking the value for his fish in cloths manufactured by the Brabanter from English wool, had taken home the amount in silver or gold.

This effect of increasing the power of metallic money by exchanges is so familiar to all who have become acquainted with commercial subjects, that perhaps some may judge this short elucidation to have been unnecessary; but though familiar to many, it is not so universally looked at as is desirable, and it seems important to notice it, because whilst it may serve to show in what manner small sums of metallic money may perform great commercial operations, it also proves how fallacious are the statements often introduced into commercial politics in the eager discussions on what is called the balance of trade.

The balance of trade will always be in favour of the country which can produce the most value in commodities with the least cost of labour ${ }^{1}$. The greater proportion of commodities in general will rest in that country, and it will possess the largest proportion of the metallic as well as of

1 According to Anderson the balance of trade in favour of England in 1354 amounted by records of authenticity to $255,214 l$. of that money, or about $590,000 l$. in money of the present day. The exports of wool, wool-fells, leather, and coarse cloth, were 294,184l., and the imports, consisting almost wholly of silks, fine cloths, wines, spices, and a few other articles of luxury which were used only by the royal family and a small number of rich prelates and great barons, amounted only to 38,970l.-Anderson's Hist. Com. vol. i. year 1354. 
other wealth, unless it be more advantageous to the community or to the richest bodies of individuals to exchange such metallic wealth for other commodities, the product of foreign countries. When commerce is free from restrictions, the gold and silver will thus flow in or issue forth according as it shall best serve the interests of the country. If it be of less value at home, it will go abroad; if it be of more value at home, it will come back; and in either case it will be a beneficial operation. As the most compendious of all commodities, and as the least liable to be injured by keeping, and as the storing it is attended with the least expense, the greatest portion will remain in the richest countries, even though it should not be all needed to perform the function of money. A part will be applied to articles of furniture and personal ornaments, and the rich country will possess a quantity of these greater in proportion to the extent of its general wealth in all commodities.

We find this to have been the case with the several countries of Europe in the period we have been contemplating. Italy was the most flourishing in commerce and the most abundant in every species of wealth, and whilst the inhabitants, who had probably learned much from the Greeks, were making a progress in the fine arts, which their wealth enabled them to pursue with success, they appear to have decorated their superb palaces 
not only with painting and statuary, but with services of plate and utensils of silver and gold. This was the practice of the Pitti and their rivals, the Medici, at Florence, and of many other families who had become wealthy in the trading cities, whether their prosperity owed its origin to commerce or to that landed property which had increased in its value with commerce.

In that age it is found that in Germany and in France gold and silver utensils are rarely noticed, and it would appear, from the descriptions given of the tournaments and of the pageants, that whatever wealth could be spared for the mere purposes of display was devoted more to the purchase of pearls and precious stones than to domestic utensils of the precious metals. Jewels could be more easily preserved in turbulent times; they could not be so readily sold, though they appear to have been frequently pledged, even by sovereigns, and hence became more valuable as heir-looms to those who wished to found families, than gold and silver, whether coined or uncoined. We find in all descriptions of the tournaments of that age that the dames of the princely and noble houses, as well as the knights, appeared decorated with jewels of great value. In England, though wealthier than Germany or France, according to its extent and population, the quantity of gold and silver applied to domestic utensils must have 
been small, notwithstanding the exaggerated descriptions of the quantity of it in some of the ancient writers. When these pompous accounts are given in exact weights, we find their amount very insignificant as compared with the general and unfixed relations of the value.

In Stowe's Survey is an account of the cofferer of the Earl of Leicester in 1313. His magnificence must have been equal almost to that of a monarch, his yearly expenditure amounting to $7309 l$. of that money, or about equal to $18,000 l$. in money of the present day, but in effective value more than equal to me hundred thousand pounds at this time. Among other heads of expenditure is a charge for three hundred and seventy-ane pipes of wine, at seventeen shillings per pipe, which may be contrasted with another article, namely, that for silver; the disbursement for which, for the same year, appears to have been for the following articles, viz. twenty-four dishes, twenty-four saucers, twentyfour cups, one pair of paternosters, and one silver coffin. The whole weighed one thousand two hundred and thirty-six ounces, and the cost of it, at one shilling and eight-pence per ounce, was 103l.5s.6d. We can scarcely suppose that the expenditure in silver by families of an inferior degree bore a greater proportion to their aggregate expenses ${ }^{1}$.

1 See Anderson, Hist. Com. vol. i. year 1513. 
The very name of the field of the cloth of gold would give a high idea of the value of the metal there displayed; but if we look at it with other eyes, the illusion will vanish. That cloth was imported from Italy, and the whole imports of England amounted to not more than fifty thousand pounds, including the products of the east, and the wines and other luxuries which the few dignified priests and nobles consumed. The value of the gold in this cloth, and indeed of the cloth itself with the gold, could be but of small amount.

At a later period, in the reign of Henry VIII., and indeed when some of the gold and silver of newly discovered America must have been diffused over Europe, we find a very particular account in Stowe of the quantity of the precious metals which was collected by Cardinal Wolsey. When entertaining the foreign ambassadors at Hampton Court, we learn that "two hundred and eight beds were provided for the guests. Every chamber had a basin and ewer of silver, and some gilt ; yea, and some chambers had two livery pots with wine and beer; a silver candlestick, having in it two sizes; yet the cupboards in the two banqueting rooms were not once touched." At the feast given to these same ambassadors, "two cupboards extending across the banquet chambers were piled to the top with plate and illuminated, and without 
encroaching on those repositories, there remained quite enough for the service of the tables."

If credit were to be given to this description of the plate of the cardinal, without any precise statement of its amount, we should be ready to estimate it at a rate more proportioned to the store of plate in noble families of the present day, than to the real paucity of such furniture in that age.

We should perhaps estimate it to be equal in value to what is reported of the Dukes of Marlborough, Devonshire, Northumberland, and Wellington, at much more than one hundred thousand pounds. We are enabled to correct this judgment by a catalogue of the prelate's effects as preserved in the Fœdera (p. 375) when they were seized and inventoried. The silver plate is stated to be nine thousand five hundred and sixty-five ounces, valued in money of that day at $3 s .8 d$. per ounce, and consequently in money of this time at $5 s$. per ounce, worth near $2400 l$.

The household book of the Duke of Northumberland of the same age gives a picture of the furniture of that nobleman, which shows how scarce the most common accommodations of the present time must have then been. Though he had three houses in Yorkshire which he inhabited in turn, he had furniture but for one, and carried every thing from one to the other at each removal. Beds, tables, chairs, kitchen utensils, all of which 
were very coarse, were conveyed from house to house in seventeen carts and one waggon, though the family consisted of two hundred and twentythree persons. In no part of the book does there appear to have been any expenditure for plate, and it seems probable that little if any was used. Pewter must have been a substitute for it, and that not wholly the property of the Duke, as one of the charges in the account is for the hire of pewter vessels without noticing the description of them.

When alluding to the rarity of utensils of gold and silver, it is impossible to overlook the article of watches, which now engross so large a share of those metals. The discovery of that invention for measuring time, which is now in the pockets of millions, may be dated not earlier than the reign of Henry VIII., and it was by no means in common use even in the reign of Elizabeth. The Emperor Charles V. had several which he seems to have kept in order by great personal attention, and our Henry VIII. had one which was noticed by Sir Isaac Newton, as being in existence in his day; but at any rate they could scarcely have been known, and certainly not common at the time of the discovery of America in $\mathbf{1 4 8 3 .}$

It could only be a conjecture, and necessarily a loose conjecture, if we were to attempt to state the proportion which gold and silver in the form of furniture bore to the quantity of those metals 
which circulated in the form of coin. It would indeed be desirable to attain to something approaching to accuracy, because the latter being alone the standard by which all other commodities, including the former, are measured, its increase or diminution might be inferred from the rise or fall of prices. 


\section{CHAPTER XVII.}

On the acquisition of the precious metals from the discovery of America in 1492, to the opening of the mines of Potosi in 1546.

The first discovery of America tended rather to increase than to gratify the eager desire for the acquisition of the precious metals. Columbus observed among the first natives he met in Hispaniola some ornaments of gold about their persons; and with the excited feelings which prevailed among his followers, and the erroneous idea he had formed of his having arrived in Asia, the supposed country of gold and silver, it is not wonderful that the slight specimens of those metals which were visible should be considered as indications of immense treasures, which by persevering efforts must soon become the property of the daring adventurers.

The aborigines of America were in that state of rude life, which induced them to carry about their persons the few ornaments they possessed; and as the gold was merely an ornament, they were eager to exchange it for any other, which by its novelty had a greater effect on their imagina. tions. We find in the narrations of the first dis- 
coverers that hawks' bells were eagerly sought for, and the golden ornaments readily given in exchange for them. It appears that an Indian gave half a handful of gold dust for one hawk's bell ${ }^{1}$. Although there is mention made of coronets of gold $^{2}$, they were only in the possession of the caciques, and no intimations are given of their weight; and it may be inferred that they were very light, from Peter Martyr having recorded as an extraordinary fact that one person had obtained a lump of gold weighing nine ounces ${ }^{3}$. It is clear that whatever gold had been collected by the natives had been procured by washing the sands in the beds of the rivers; and as that requires a degree of labour, such as the wants of the Indians could not induce them to apply with energy and perseverance, it is scarcely possible it should have been of a large amount. Neither the first nor second vessels that returned from America brought any gold except a few trinkets. The expenses of the expedition and the small fruits of the discovery were a constant subject of complaint among the ministers of Ferdinand, and with difficulty surmounted by the persevering spirit of Isabella.

After twelve years' occupation of Hispaniola and the subjugation of its inhabitants, attempts

1 Washington Irving's History of Columbus, vol. i. p. 330. 2 Idem, vol. i. p. $346 . \quad$ I Idem, vol. ii. p. 78. 
were unavailable to extract much gold by the exterminating degree of labour that was imposed by those rigid governors who had succeeded to the milder rule of Columbus. In the regions where gold was found in the streams, each individual, above fourteen years of age, was required to pay, every three months, a Flemish hawk's bell of gold dust (equal in the present day to twenty shillings in silver); and the caciques were called upon to pay a much larger amount-one of them, Maniocatex ${ }^{1}$, as much as ten pounds in three months. This was, however, found to be far more than could be obtained, and the requisition was reduced to one half; but even this demand produced despair among the natives; they abandoned the labour of their fields; a scarcity of the means of subsistence soon followed : what little was to be found was seized by the Spaniards; great numbers of the Indians were left destitute of food, and thus many of their tribes were thinned or extirpated by absolute starvation ${ }^{2}$.

As the possession of Hispaniola produced gold in such small quantities, and as even this was exhausted within twenty years after the discovery, in spite of the forced labour of the aborigines, it is not surprising that the expectations of the adventurers of immense mineral wealth should

${ }^{1}$ Irving, vol. ii. p. 276.

${ }^{2}$ Idem, p. 282. 
have led them to extend their incursions and examinations in every available direction.

Mr. Irving, with his usual diligence and taste, has compiled from the best authorities authentic accounts of those immediate followers of Columbus who pursued his views by exploring the several regions which lay in the vicinity of the great islands which he had discovered.

The subject is interesting, but might in this inquiry be seductive enough to draw attention to the adventurous and persevering individual leaders, and to withhold it from the small portion of the precious metals which was found in America at the period of its first discovery. In the "Voyages of the Companions of Columbus," we find Alonzo de Ojeda, as early as 1509, on the coast of Carthagena, after successful hostilities against the natives, who were in a more civilized state than the inhabitants of Hispaniola, found in the plunder of their chief place, "the spoil in gold and other articles of value to the amount of seven thousand castillianos," or thirty-seven thousand two hundred and eighty dollars, equivalent to about eight thousand pounds sterling ${ }^{1}$. Diego de Nicuesa, who followed the steps of Ojeda, and made conquests on the shores of Darien, collected great quantities of food and cotton, with bracelets, anklets, plates, and other 
ornaments of gold to the value of ten thousand castillianos, or about eleven or twelve thousand pounds ${ }^{1}$. Vasco Nunez de Balboa, who followed Ojeda and Nicuesa on the continent of America, and who first discovered the south sea, had, in 1513, collected such a quantity of effects of various kinds that the fifth part, which belonged to the crown, and was remitted to Diego Columbus in Hispaniola, amounted to fifteen thousand crowns of gold ${ }^{2}$. After his discovery of the South Sea, Vasco Nunez is said, but on authority doubtful as to the exact weight, to have received in the isthmus of Darien, from one cacique, five hundred pounds of gold, in exchange for beads, hawks' bells, and looking-glasses. On his return over the mountains, he is related to have collected from two caciques seven thousand crowns more in pearls and gold ${ }^{3}$. In another subsequent expedition in the isthmus, against a chief named Tubanama, he obtained "amulets and other effects of gold" to the value of two thousand crowns from the cacique himself, and from his subjects to the amount of six thousand ${ }^{4}$.

The scenes of these exploits on the coast of Carthagena and in the isthmus of Darien were

1 Page 124.

${ }^{2}$ Irving, p. 150. The crowns of gold in that day weighed seventy grains, of which two were alloys, and consequently were worth in our present money about ten shillings and sixpence. See Diccionario de Hacienda por Argüelles, tomo ii. p. 211.

${ }^{3}$ Page 188 and $192 . \quad{ }^{4}$ Page 196. 
sufficiently near to the richer countries of Mexico and Peru for some of the precious metals to have been derived from those sources. The streams of their own mountains might have furnished some to even the most negligent searchers; and hence, though it is not possible to read the accounts of that period without some suspicion of exaggeration, yet when we consider the ages that may have passed in collecting gold, there seems less reason to suspect any great mistatement in the relation of the facts. In truth, the whole quantity for the first twenty-five years from the date of the discovery to the possession of Mexico and Peru was very small even if compared with the diminished quantity which then existed in the ancient world.

Humboldt has estimated the average annual amount of gold and silver which America furnished to Europe in the period from 1492 to 1500 at about 52,000l. sterling ${ }^{1}$. No writer, perhaps, is entitled to more implicit credit for any fact which came within his own knowledge; few deserve more attention to any estimate which he has formed. In this estimation could only be included that which the natives had collected before the arrival of the Spaniards, for the tribute imposed on the Indians by the successor of Columbus did

1 Political Essay on New Spain, vol, iii. book iv. cap. xi. p. 433. 
not come into operation till the expiration of the period. It was not till 1502 that Ovando despatched to Europe the first large quantity of gold, the greater part of which was lost in the storm, which wrecked most of the vessels, and the whole of what was shipped did not exceed 2560 marcs in weight, and may be valued at between $70,000 l$. and 72,000l. sterling.

It seems necessary to guard against the exaggerated language of the early discoverers of America, who speak of enormous quantities of gold, of immense wealth, of vast treasure; and to correct this language by figures whenever in their relations we meet with any. In this way, instead of deeming Humboldt to have diminished the actual quantity of gold and silver found in America, we shall be disposed, if we venture to dissent from his results, to believe that he has rather under than overstated the quantities. According to the accounts of the various Spanish writers, the gold collected by the successors of the first explorers, from the year 1500 to the invasion of Mexico by Cortes in 1519, may have equalled, but scarcely could have exceeded, that which Humboldt estimates as the annual produce afforded by America between 1492 and 1500 , or about 52,000l. sterling. If, then, in the twenty-seven years between the first discovery by Columbus in 1492 to the landing of Cortez in Mexico in 1519, the annual produce of gold be estimated at $52,000 l$. we shall 
adopt an estimation in the particular period somewhat below that of Humboldt in the latter years, but not more varying than seems justified by the accounts of Herrera and others respecting the operations of various early adventurers.

It is to be observed that, up to the invasion of Mexico, gold alone had been found in America, or, if any silver had been procured, it must have been in such small portions as not to be thought worthy of mention by any of the narrators of the events of the period.

Cortez commenced his invasion of Mexico in 1519, and a great portion of the precious metals which had been collected in that country during the period of the existing government fell into his power. At his advance towards the capital, the presents he received at Chalco are stated by himself to have amounted to 2560 marcs of gold, or nearly \%0,000l. sterling. Montezuma, on taking the oath of fidelity to the Emperor of Spain, was prevailed upon to pay a tribute which, calculating from the fifth part paid into the chest of the army, must have amounted to near $65,000 l$. At the capture of Tenochtitlan, the plunder which fell into the hands of the Spaniards is stated by Bernal Diaz to have been equivalent to $80,000 l$. These instances of mineral wealth found by Cortez and his followers show that the Mexicans must have made some progress in mining operations before their country was visited by Europeans; and though 
the quantity was small when compared with the product of succeeding centuries, it formed a sufficient indication of what might be obtained by more strenuous and persevering operations.

As soon as the Spaniards had gained full possession of the country, they employed the wretched natives in the laborious work of procuring the precious metals. The masters had little skill, the depressed inhabitants but little industry, yet, in the space of thirty or forty years from the subjugation, mines were at work at Tasco, at Zultepeque, and Pachuca, which, if they yielded little treasure when compared with the more modern products of Valenciana and other rich districts, yet brought into activity sufficient to show what great application might effect, and enough, combined with a similar process in Peru, to produce a great influence on the transactions of the ancient continent as soon as it had reached the ports of Europe.

Twenty years after the conquest of Mexico had been achieved by Cortez, Pizarro accomplished a similar conquest in Peru. The inhabitants of that country were of a milder character than those of Mexico; they had practised more industry generally, and had especially been more successful in their operations for procuring mineral wealth. The process by which the Peruvians had procured their gold and silver before the arrival of the Eurcpeans was, as may be expected from people in such a

VOL. II. 
stage of society, simple, rude, and with little regard to extracting the whole of the precious metals from the ores. The mines had been wrought for the Incas, and the use of mercury had not been adopted till more than forty years after the conquest. 'The smelting was performed in small portable furnaces or cylindrical tubes of clay, very broad and pierced with a great number of holes. In these the Indians placed layers of silver ore, galena, and charcoal, and the current of air which entered the holes quickened the fire and gave it a great degree of intensity. These furnaces were moved from one elevation to another according to the degree of high or low wind. When it was found that the wind blew too strong and consumed too much of the fuel, they were removed to a lower situation. By these means the natives obtained argentiferous masses, which were smelted again in their own cottages. This was performed by a number of persons, ten or twelve at a time blowing a fire through copper tubes, from one to two yards in length, pierced with a small hole at the extremity towards the fire, which thus acted in the same manner as the modern blowpipe. By such processes as these, though a very large portion of the silver must have remained in the scoriæ without combining with the galena, yet such a quantity could be obtained as would satisfy the demands of the fiscal officers of the Inca. 
To this method of working may be attributed the quantity of metallic treasure which Pizarro was enabled to extort from the Inca Atahualpa as his ransom, which, according to Garcilasso de la Vega, is stated at the enormous sum of eight hundred thousand pounds, or, according to Gomara, at the more probable amount of one hundred and forty thousand, or one hundred and fifty thousand pounds. The plunder of Cuzco was also very large, and though the amount of it is only given by Herrera, a writer long posterior to the event, and whose authority does not appear, may be exaggerated at four hundred thousand pounds, yet there is evidence sufficient to prove that the treasure found in that city was more than could have been collected if it had all arisen from washings, and if the Indians had not worked some of the mines.

As soon as the Spaniards had secured their conquest, the greater part of the original inhabitants were reduced to a kind of feudal slavery, known by the name of repartimientos. The people of the several mining districts were delivered over to Spanish officers, who compelled them to labour for their benefit either in cultivating the land, in digging in the mines, or in any servile or domestic labour. They were marched in bodies a long way from their homes, to climates from their elevation of intense coldness, and widely differing from those 
fertile sumny valleys which were their favourite abodes till visited by the Europeans. The Mexican Indians endured less oppression in this respect than those in Peru, but much labour was extorted from both, and the fruits of it was an increased quantity both of gold and silver, within a short space after the conquest of the respective countries.

The mines opened in Mexico during the period which followed the conquest have been already noticed, to which may now be added those explored and worked in Peru between the landing of Pizarro in 1527 and the discovery of the mineral wealth of Potosi in 1545. The chief mines opened in Peru before Potosi were those in the provinces of Porco, Carangas, Oruro, Carabaya, and Chaquiapu, now called La Paz. There are no accounts to be found of the quantities they produced, but merely their names are mentioned respectively as yielding either gold or silver, or both.

In estimating the addition made to the store of the precious metals by the discovery of America from the year $14: 92$ to 1546 , it seems necessary, after much attention to the subject, to deviate but little from the calculation which Humboldt has made, and that chiefly in the earlier years of the series. The annual addition then in the twentynine years between the discovery in 1492 to the conquest of the city of Mexico in 1521, at the rate 
of $£ 52,000$, would amount to $£ 1,308,000$

The amount for the twenty-five years from the capture of Mexico to the discovery of Potosi, at the annual rate as estimated by Humboldt of $\mathfrak{f 6 3 0 , 0 0 0}$

$15,750,000$

Total addition in sixty-three years $£ 17,058,000$

By a calculation before made in chapter $x$. of this inquiry, the quantity of the precious metals in existence in the ancient world has been estimated to have been reduced down to thirty-three or thirty-four millions. It has been also calculated that the mines of Europe yielded at the time of the discovery of America a portion of gold and silver equal to that which was annually consumed by wear. If these various calculations approximate to truth, it would appear that an addition had been made to the gold and silver in existence at the rate of fifty per cent., or one half of the previous quantity.

The process of consumption would, however; be going on contemporaneously with the production. In this period the largest quantity would be produced in the earliest and the latest years. That which had been accumulated in prior ages by the aborigines would be acquired by the conquerors, and it would require some arrangements before the labour of the subdued inhabitants could be directed and excited in such a manner as to bring 
into action the treasures contained in their soil. In the fifty-seven years, upon the principle assumed in this inquiry as the rate of consumption by friction, the loss upon the new acquisitions of the precious metals would amount to about one million five hundred thousand pounds, and the whole quantity in existence may perhaps be fairly estimated at about fifty millions sterling.

It is impossible to form any calculation of the proportion which that part of the precious metals which was converted into money bore to that which was applied to purposes of ornamental or useful articles. The first would have an influence on the prices of all commodities; the latter falling into the general mass of commodities would have no influence on them.

The age in which America was discovered was one of intense religious feeling. New doctrines had been propounded with zeal by its adherents, which were rejected with equal zeal by their opponents. The Spaniards who received the gold and silver from the new world were remarkable for the most rigid adhesion to the ancient faith. Their veneration for its imposing and showy ritual, and their belief that presents to the virgin and the saints would benefit their worshippers, had the effect of drawing to the public or private temples a portion of the first fruits of those precious metals which America had yielded to their perseverance. The same feeling pervader the rest_of Europe; and as the gold and 
silver were gradually transferred by commerce or by war to the several other kingdoms, a portion of those metals was devoted by piety to the service of the deity and the saints. The protestant religion, though it had raised its head, was then in a weak condition, struggling not for the mastery but for existence; and its influence was not such as in any great degree to check the prevailing disposition, to dedicate to the purposes of devotion some portion of every new acquisition of wealth. When the goods of Cardinal Wolsey were confiscated, his plate was large for the age, as has been already noticed; and most of the heads of the religious houses in England, when their property was seized by the rapacious Henry VIII., appear to have possessed some store of gold or silver utensils. It was not, however, in England that the largest portion of the metallic wealth was withdrawn from circulation to adorn religion. In Spain itself; in Italy, then rich in general wealth acquired by commerce; in the Netherlands, which had been enriched by manufactures; and in the ecclesiastical states of Germany, whose agriculture had been flourishing, the decorations of the religious houses were increased, the dress of the officiating priests was covered with gold and silver embroidery, and the vessels for the holy rites were changed gradually from copper or pewter to silver.

The extension of gold and silver utensils was 
not confined to ecclesiastics, but extended to the princes, to the richer nobles, and in the free commercial cities to the more opulent burghers and merchants.

It does not seem probable, however, that a large proportion of the metallic wealth of that age would permanently remain in the quiet possession of even religious communities. The wars which were almost constantly carried on during the reign of the emperor Charles V., and especially those in Italy betwixt him and Henry I. of France, had exhausted the treasures of the sovereigns, and induced them to seize on much of the ecclesiastical wealth to coin into money to pay and support their armies. Among numerous instances of pillage in that age is a remarkable one of Henry I. of France, who stripped the tomb of St. Martin of a railing of massive silver, with which, in one of his fits of devotion, Louis XI. had encircled it. Another most striking instance is that of the capture of Rome itself by the imperialists under Bourbon in 1527. It is recorded that neither the barbarous and heathen Huns, nor the Vandals and Goths in former ages, had extorted plunder by such outrageous means as were adopted by the bigoted subjects of a catholic monarch, who spared neither churches, monasteries, nor palaces, nor the houses of private persons, and who collected booty to the amount of a million ducats. 


\section{CHAPTER XVIII.}

On the acquisition of the precious metals from the opening the mines of Potosi, in 1546, to the end of the year 1599.

Is the latter end of the year 1545 the mines of the Cerro de Potosi were accidentally discovered. According to the account of Herrera, the discovery was owing to an Indian hunter, Diego Hualca, who in pulling up a shrub observed filaments of pure silver about the roots. On examination the mass was found to be enormous, and a very great part of the population was thereby drawn to the spot and employed in extracting the metal. A city soon sprung up, though in a district of unusual sterility. The mountain was perforated on all sides, and the produce in a few of the first years exceeded whatever has been recorded of the richest mines in the world.

'There are great doubts of what was the real quantity of treasure actually brought into existence from Potosi in the first ten years after the discovery. Humboldt, who examined the matter with his usual diligence and acuteness, says, "the books of accounts preserved in the archives of the provincial treasury of Potosi go back no farther 
than the year 1556 ; but it is very reasonably believed that the first years which followed the discovery of the veins were the most productive in riches." Although the actual amount in the first ten years must be a matter of doubt, yet some judgment may be formed from the succeeding twenty-three years, from 1556 to 1578 , of which the accounts have every appearance of veracity.

The Emperor Charles the fifth granted to his celebrated secretary of state, Don Francisco Tomas de los Cobos, for two lives, a maravedi on each marc of silver raised in Potosi. This gave rise to the tax afterwards imposed of a fifth of the produce. The account of the Cobos, the impost having taken the name of the person in whose favour it was first granted, from the years 1556 to 1578, gives, as the amount of the tax, nine millions eight hundred and two thousand two hundred and fifty-seven pesos, and consequently the treasure produced must have amounted to forty-nine millions eleven thousand two hundred and eighty-five pesos or dollars, or annually to two millions one hundred and thirty thousand nine hundred and twenty-five pesos, or about four hundred and forty thousand pounds sterling ${ }^{1}$.

Sandoval, Ulloa, and Solarzano, all of whom are quoted by Humboldt, would lead us to sup-

${ }^{1}$ Diccionario de Hacienda, vol, i. page 102. 
pose that Potosi, in the earlier years of its working, yielded much more than is here estimated; but whoever has paid much attention to the more ancient Spanish writers, especially when they speak in round numbers, will receive their relations with considerable hesitation.

There are some considerations which would lead to a doubt whether Potosi produced, in the first tell years of its being worked, so large a quantity of silver as in the years that followed after 1556. The Indians, who had been compelled to perform the labour, must have been unaccustomed to it, and would require time to gain the habit of working with effective expedition. The method of extracting the silver by the process of amalgamation had not been introduced, as it was not discovered in Mexico, from whence it was carried to Peru, till the year 1557; and the mines of mercury in Guancavelica had not then been opened, and till they were, the amalgamation process could not have been used. As the miners of Potosi could only obtain the silver by smelting, and as fuel was not to be procured near the Cerro, a difficulty would present itself which could not be overcome so completely as it must afterwards have been when the practice of amalgamation was introduced.

The feeling of confidence in Humboldt is so much increased by every examination of his statements, that any slight difference from his repre- 
sentations seems to require an apology. The differences, however, do not greatly affect the view now taken of the subject, in this case extending over a period of ten years out of fifty-five; they would not have been noticed, if it had not arisen from a more attentive examination of the accessible documents than the proportion which it bears to the whole view would have induced.

Humboldt procured correct returns of the amount of the Cobos at Potosi, from the year 1579 to 1789 , from which he has calculated the quantity of money procured in those years in a manner deserving the highest confidence. At present we have only to do with the years from 1579 to 1600 . This appears in the twenty-one years to have amounted to twenty-nine millions one hundred and eighty-five thousand nine hundred and ninety pesos, or one million three hundred and eighty-nine thousand eight hundred and fifty-nine annually, being equivalent to about two hundred and eighty thousand pounds on the average.

We have thus examined the statement of the Cerro de Potosi with more minuteness than will be necessary to apply to other mining districts, on account of the long and extensive fame which that mountain has enjoyed, and to reduce, as far as can be done, to accurate figures the extravagant representations to which we have all been accustomed from our childhood. 
Besides those mines in Peru which have been already noticed in the period immediately following the discovery, and which continued in activity during this second period, some others were opened, though upon a small scale, at Huantajayo and Porco, within that viceroyalty. Chili, in this period, came into the possession of the Spaniards, and the products of that district, chiefly consisting of gold, augmented the supply. Antioquia, as well as Choco, furnished some gold as early as 1539, and continued to do so from the time of the conquest to a late period. The greatest produce of gold and silver, even in that day, was from the Mexican mines; some of the most rich were in this period in a state of activity, though far inferior in the quantity they yielded to the point they had reached in the course of the two following centuries, when the supply of quicksilver became more abundant and was more extensively employed in the process of amalgamation. Brazil in the hands of the Portuguese, at the same time, had employed the natives and some negro slaves in washing for gold; the quantity thus procured cannot be accurately ascertained. There is only the statement of Raynal on the subject, and none of his accounts are entitled to credit, unless supported by some better authority, which in this case he has not furnished.

In the estimation of the quantity of gold and silver added to the previous stock, which in 1546 
has been already calculated at about fifty millions sterling, we may venture to consider the annual supply on the average of the period to have nearly approached to ten millions of piastres or dollars, or about two millions one hundred thousand pounds sterling. This is so near to what Humboldt has reckoned it, that there seems no necessity for entering farther into the causes of the variation.

The miners in Europe were excited by the successful operations in America to greater exertions, especially those in the Pyrenees, and in several parts of Languedoc, and it may be concluded from various representations that the annual supply from the ancient continent had amounted to about one hundred and fifty thousand pounds.

We thus assume that the aggregate additions of fifty-four years were at the annual rate of two millions two hundred and fifty thousand pounds sterling, or that in the whole term the amount of one hundred and twenty-one millions had been produced, to which the fifty millions before in existence being added, would give as the quantity in the year 1600 about one hundred and fifty millions.

The process of consumption would, however, be going on, and operate on the whole amount. There seems no reason in estimating the gradual diminution in this period at a different rate from what has been before assumed. We continue, 
therefore, to calculate that one part in three hundred and sixty was annually consumed, or one tenth part in thirty-six years. On these principles the diminution on the fifty millions in existence in 1546 would reduce them in fifty-four years to forty-two millions seven hundred and fifty thousand pounds. The same gradual loss would be suffered on the one hundred and twenty-one millions, but that can only be taken as the operation of the mean term of years, or of twenty-seven years. This diminution would thus amount to about nine millions, and the result to which we arrive would be that at the end of the year 1599 the stock of gold and silver actually in existence amounted to about one hundred and fifty-five millions ; or as it may be stated in round numbers, at nearly five times as much asw as in the possession of mankind in 1492, when America first became known to the Europeans. It would be of great advantage to the purpose of this inquiry to ascertain in the period under consideration, what proportion of the gold and silver obtained was applied to conversion into coin, and what to the fabrication of articles of utility, magnificence, or luxury. Instead, however, of attempting to hazard conjectures on so obscure a subject, we must be content with such general observations as the aspect of the several countries of Europe present on looking at their modes of thinking, and their manners and habits. The Spaniards, into whose possession the 
first harvest of the mineral treasures of America came, were as a nation most intensely imbued with religious feelings. Whatever description may be given to the chrictianity that had formerly prevailed in Spain, it had in the contest of seven centuries with the Moors who were settled among them, and who possessed the most beautiful and fertile portions of their country, been changed into a chivalric feeling, having little connexion with the common duties of life, but exciting them to bold achievements, to the endurance of severe privations, and to a strenuous exertion in such enterprises as could inflict injury on the Mahometan unbelievers. Their piety was not that of the humble. devotee fraught with feelings of repentance, and accompanied with resolutions of amendment, but of warlike partisans fighting for the power or the purity of the holy virgin, or for the excellence of real or imaginary saints, to whose honour they had devoted their swords and their zeal. To propitiate these beings, they vowed to dedicate a portion of the spoil acquired by their adventurous rapine; and hence the churches, the shrines, and the altars were decorated with the gold and the silver collected by the first expeditions to the American shores.

'The irruptions of the Mahometans into the districts around them rendered the treasures of the churches insecure, till the final conquest of that race had produced internal tranquillity at the 
moment when the gold and silver of America reached the country. Whoever has read the histories of the early invaders of America must have remarked how profuse Columbus and his followers were in vows of presenting such offerings, and will readily believe that many of such vows were duly performed. Several of the most magnificent and costly cathedrals of Spain owe their construction to the zeal of the period, whilst others of more ancient date received images, crucifixes, pattins, chalices, and other vessels, in the room of such as had been seized by the Moors, or as had been converted by the Christian into money to furnish the means for repelling or subduing the unbelievers ${ }^{1}$. The domestic peace which Spain enjoyed from the time of the conquest of Granada must have tended to increase the mineral treasures which the church drew to itself, and no strong motives presented themselves to cause any abstraction of those treasures.

In Italy, also, much had been appropriated to similar purposes in Rome, as well as in the other cities; but the frequent wars of which it was the theatre probably tended to withdraw much of it from sacred purposes, and to convert it into the more current form of money. We have already noticed the treasure seized by the army of Bour-

1 The twenty volumes of the work of Don Antonio Ponz, entitled "Viage de España," contain particular relations of the decorations of the churches about this date. 
bon in Rome, and we may easily believe that the soldiers of the catholic emperor would not hesitate to apply the same rapacity to the other catholic churches. The progress of the reformation in the north of Europe had lessened what little disposition had existed of a profuse expenditure in decorating the churches. The inhabitants had never indulged in those feelings of chivalrous religion which were the characteristic of the natives of Spain; and though they built costly cathedrals and monasteries, either from their want of the same kind of enthusiasm, or from their poverty, they were much less furnished with gold and silver utensils and ornaments than similar establishments in the peninsula.

A considerable progress, however, appears to have been made, in this period, in the application of the precious metals to articles of domestic ornament and accommodation. The rich burghers of Antwerp, Ghent, and the other cities of Flanders, are stated by Guicciardini to have had their houses furnished with many vessels of massive plate. We find Hollingshed, when speaking of the increase of luxury in England, after noticing the introduc-: tion of pillows, and censuring it as effeminate, complains of " the exchange of treene platters (or trenchers) for pewter plates, and of wooden spoons for those made of silver."

Many of our English nobility in this age had large stocks of plate, especially the Earls of Lei- 
cester and Derby, who displayed their magnificence in their several entertainments to Queen Elizabeth. It appears that Burleigh possessed a large quantity of plate. It is doubtful if it was of the value of fourteen thousand pounds sterling, or fourteen thousand pounds weight, which would have been worth forty-two thousand pounds sterling; but the probability is in favour of the larger sum ${ }^{1}$. Such stores would, however, be in the possession of a very few individuals, and the whole could not produce a very. great effect on the mass of gold and silver which had been afforded by the mines of America in the century.

Whatever it may have amounted to, it must have frequently passed from the form of utensils to that of coin; for as there was no tax on the silver goods, and as the fashion was of little cost, it would be worth no more than its weight as bullion; and it appears by the will of Burleigh, that in the bequests of the plate to his family he specifies only the number of ounces to be given to the legatees, and appoints a goldsmith to see it weighed out to them, without making any distinction of the pieces.

During the period we are now viewing, a course of events commenced in the commerce of the world which had a great influence on the precious

1 See Hume's History of England, where in the Appendix, No. 3, and in note ${ }^{\circ o}$ to the fifth volume, this matter is discussed and apparently settled. 
metals. The route to India by the Cape of Good Hope, which the Portuguese had discovered, induced other nations to follow in their steps. As silver was found the most ready and beneficial article to exchange for the commodities of the east, a great transfer took place of that substance between the European and the Asiatic world. This did not affect the quantity produced, but changed the locality of it. In that change, however, it seems more than probable that a large portion of the silver which passed to the east was abstracted from the use of it as money, and applied to purposes of magnificence and splendour.

From all we can learn of the ancient history of India, we are warranted in concluding that at the court of the Great Mogul, and among the numerous feudal sovereigns who ruled in that country, luxury in the use of gold and silver ornaments was carried to a much higher point than in Europe in that time, and indeed beyond what is indulged in either in Europe or Asia in the present day. In India, as well as in the extensive empire of China, at all times, the difference between gold and silver in coin and in utensils was very slight. It has been the general practice to pass the precious metals from hand to hand by weight, only first ascertaining the purity of the metals by the trials of the shroffs, who have been always skilful in assaying.

In the eastern part of Asia the Turks had be- 
come a more settled people than in the former centuries. Their government, which had been suffered to rest after the annoyances of the crusades, assumed more magnificence, and allowed to the people more leisure to follow profitable pursuits. Their exports drew from western Europe annual supplies of gold and silver, and the sultan and his great officers accumulated in their palaces some portions of these metals, and applied them to ornamental or useful domestic purposts. From the compendious nature of the metals, and from the suspicious character of the government, it is probable that a large portion, in comparison with the whole quantity in Turkey, must have existed in that form rather than in coin.

There is no evidence that any part of the produce of the precious metals from the American mines had passed direct from that continent to Asia during the sixteenth century. Whatever supply Asia received beyond the products of its own mines must have been derived from Europe by its commerce, and it is well known that what passed either by the Cape to India and China, or by the-Levant to Turkey, Persia, and Arabia, bore but a small proportion to the whole quantity which America supplied.

In the absence of any precise facts, and with but little confidence in an approximation to accuracy, we may venture to suppose that the precious metals which passed from Europe to Asia in the 
hundred and twelve years from the first discovery of America to the end of the sixteenth century amounted to one-tenth of the whole quantity produced, or about fourteen millions; and we may further suppose that one-fifth of the gold and silver had been abstracted from its primary use as money, and converted into other commodities either for use or for ornament. This would amount to about twenty-eight millions. The sum, then, which formed the stock of money current in Europe at the latter end of the sixteenth century would be composed of the stock existing at the time of the discovery of America, $\mathfrak{E} 34,000,000$ that produced in the hundred and twelve subsequent years, after making allowance for the loss by natural wear,

$172,000,000$

deducting from it what had been conveyed to Asia, and what is supposed to have been applied to the purpose of commodities of all kinds, $\quad 42,000,000$

$£ 130,000,000$

The stock of gold and silver coin in Europe may then be estimated, at the end of the year 1599 , to amount to one hundred and thirty millions of our present money. 


\section{CHAPTER XIX.}

On the rise of prices simultaneously with the increase of gold and silver in the first century after the discovery of America.

$\mathrm{H}_{\mathrm{AV} \text { ING }}$ arrived at a conclusion which will admit of great difference of opinion, and of the probability of which every reader must form his own judgment, that the quantity of coin in Europe had in the first century from the discovery of America been nearly quadrupled; we will now consider the effect produced by so vast an alteration in the quantity of that standard by which the value of all other commodities was measured.

If we could suppose that the general mass of commodities which are the subjects of exchanges had increased in the same proportion as the precious metals, and were always exchanged by the intervention of those metals, we should naturally infer that the prices would remain stationary. If the mass of commodities increased at a greater rate than the metals, we should expect that prices would decline; but if those metals increased faster than the whole of the other commodities, we should look for an advance in the prices of commodities generally. 
Difficult as the task has been found even to conjecture what has been the increase or decrease of the precious metals, and doubtful as are the results at which we have arrived, any estimation of the increase of commodities generally in Europe would be a far more Herculean task, and the conclusions that might be drawi would be infinitely more disputable.

In order to approximate to truth as nearly as the subject will admit, we shall advert to the prices of commodities in the two periods about the years 1480 and 1599, both in England and in France. For reasons which have been before stated at length ${ }^{1}$, we must have recourse to corn, that commodity which can alone guide us; which, though the only one whose certain prices are given, is, on account of the fluctuations in its productiveness, one of the most uncertain. It happens, too, that in the period under consideration the variations of several years seem to be enormously great.

In a work entitled "A true Relation of the most remarkable Dearths and Famines which have happened in this Realm since the coming in of William the Conqueror up to Michaelmas, 1745," 4to. printed in 1748, there are some facts well worth noticing and preserving. In the following extracts the money of the several dates is re- 
duced to money of the present day, in conformity to the scale stated in vol. i. p. 324 and 325.

"In the year 1491 (7th Henry VII.) wheat was sold at London for three shillings and fourpence the bushel, which was accounted a great dearth. In 1494, wheat was sold at the same price. In the 13th Henry VIII. was a dearth of corne (with pestilence), for wheat was sold in London for forty shillings the quarter. In November, December, and January, 18th Henry VIII. (1526), fell such abundance of raine that thereof ensued great floods, which destroyed corne fields, pastures, and beasts. Then was it drie till the 12th of April, and from that time it rained every day and night till the $3 \mathrm{~d}$ of June, whereby corne failed sore in the yeere following. In 1527 (19th Henry VIII.), such scarcity of bread was in London that many dyed for want thereof. The king sent to the citie of his owne provisions six hundred quarters. The bread-carts then coming from Stratford were met at the Mile-end by a great number of citizens, so that the maior and sheriffes were forced to goe and rescue the same, and see them brought to the markets appointed, wheat being then at thirty shillings the quarter; but shortly after, the merchants of the stiliard brought from Danske such store of wheat and rye that it was better cheape at London than in any other part of the realm."

“ In 1553, the first yeere of Queen Mary, at her majesties coming to the crowne, victuals were so 
plentiful that a barrel of beere was sold for eightpence, and four great loaves of bread for one penny. and a farthing. In 1557 (5th Mary) wheat was sold before harvest at thirty shillings the quarter, but after harvest, at seven and sixpence, so that a penny loafe, which weighed in London the last yeere but ten ounces troy, weighed now twentysix ounces. In 1558 wheat rose again to twentythree shillings the quarter. In 1573. (8th Elizabeth) about Lammas, wheat was sold in London at three shillings and three-pence the bushel, but shortly after it was raised to four shillings and four-pence, five shillings and sixpence, six shillings and sixpence, and seven shillings and nine-pence, which continued long after, yet there was no want to him that wanted not money."

In other accounts, especially in the Chronicon Preciosum, we find the prices at some intervals of the period very low; as in 1494 at six shillings per quarter, in 1495 at five shillings, in 1499 at six shillings; and at other times, as in the years 1551, 1552, 1553, 1554, 1555, 1556, 1557, 1558, $1559,1560,1561,1562$, there was no variation, the price being in each of those years eight shillings the quarter, or eight shillings and ten-pence of our present money ${ }^{1}$.

${ }^{1}$ It is observed by Fleetwood (page 122) that the price of wheat did not remain fixed exactly at eight shillings during the whole interval, but that the variations were so inconsiderable that the proprietors of the land, in settling the rent of it with the farmers, agreed that it should be estimated at that price during the whole twelve years. 
The several laws: passed between the years 1554 and 1604 are, perhaps, the best criterion of the increased average price of wheat, because they show what was deemed by the legislators a price so low as rendered it proper to admit of its being exported to foreign countries; and they seem more appropriate, because the first of these laws passed at the time when the mines of Potosi had just began to flow from Spain through the rest of Europe.

By the acts 1 and 2 Philip and Mary, cap. 5 , in 1554, corn is forbidden to be exported except.when the price of wheat shall not exceed six shillings and eight-pence, of rye four shillings, and of barley three shillings, per quarter. By an act, 1st Elizabeth, cap. 11, corn may be exported when the prices do not exeeed for wheat six shillings and eight-pence, rye four shillings, and barley three shillings, per quarter. By another act of the fifth of the same reign, exportation was allowed when wheat does not exceed ten shillings, rye eight shillings, and barley six shillings and eight-pence, per quarter. The next act, that of 1593, 35th Elizabeth, cap. \%, sec. 8, allows wheat to be exported when not above twenty shillings; and by the act 1 st James I., cap. 25 , sec. 26, 1604, the exportation of wheat is allowed when the price does not exceed twenty-six shillings and eight-pence the quarter. It seems then clear that the legislators who framed these several laws must have concurred in judging what was 
the proper standard by the respective rates of the several periods. If the price of six shillings and eight-pence for wheat in 1554 was deemed a fair standard for both consumers and producers, it may be inferred that fifty years later the price of twenty-six shillings and eight-pence, in 1604, was an equally fair standard ${ }^{1}$.

It is a subject of regret that the Oxford prices of corn, for which the public is indebted to $\mathrm{Mr}$. Lloyd, present a blank from the year 1328 to the year 1583; we are not, therefore, able to make from them a contrast between the two periods which it is desirable to compare. The average price of wheat, by Mr. Lloyd's tables, for the ten years from 1583 to 1592, appears to have been twenty shillings and nine-pence; of the ten years from 1593 to 1602, thirty-three shillings and three-pence; and from 1603 to 1612 , thirty-one shillings and four-pence. It has been before shown, from the Chronicum Preciosum, that the average price in the twelve years, from 1551 to 1562, in which there was no variation, was eight shillings and ten-perice.." The parliamentary rate

1. These advances in the legal price to which wheat must rise before it was exportable were continued by acts of parliament, thus :

1623 by 21 st James 1., cap. 28 , at . . . . 32s. 1627 by 3 rd Charles I., cap. 4 . the same rate continued. 1656 by Cromwell ordinances, cap. 5 . . . 40s. 1663 by 15 th Charles II., cap. 7 . . . . . 48s. 1688 by lst William and Mary, cap. 2 . . 48s. with a bounty of $5 s$. when at or under . . . $48 s$. 
of prices would give in fifty years an advance from six shillings and eight-pence to twenty-six shillings and eight-pence, or a threefold increase. The Oxford tables, as compared with prices in the Chronicon from eight shillings and ten-pence to thirty-three shillings and three-pence, show an increase of near fourfold. It is possible this apparent discrepancy may arise from the difference of measure. Mr. Lloyd's prices are calculated by the Winchester bushel of eight gallons. By an act passed in the 15th Richard II., cap. 4, corn is ordered to be sold only by the quarter of eight bushels; but it seems doubtful how far that law was operative, for the Oxford prices, though reduced into the quarter of eight bushels, are kept in quarters of nine bushels, as are also those of Eaton.

In the sermons of Bishop Latimer, especially in those preached before King Edward VI., are to be found several allusions to the advance of prices which had taken place at that early period after the discovery of the mines of Potosi. The first was delivered " in the shroudes at Paules church in London, 17th day of January, 1548 :" in that he relates the history of himself, or rather of his family, saying, "My father was a yeoman, " and had no landes of hys owne, onely he had a " farme of three or four pounds by yeare at the " uttermost, and hereupon he tilled so muche as " kept halfe a dossen men. He had walke for an " hundred sheepe, and my mother milked thirty 
"kyne. He was able and did finde the king a " harnesse, with himselfe and his horse, while he " came to the place that he should receive the " kinges wages. I can remember that I buckled " his harnesse when he went into Blackheath field. " He kept me to schole, or els I had not been able " to have preached before the kinge's maiestie now. " He married my sisters with five pounds or " twenty nobles apiece, so that he brought them " up in godlinesse and feare of God. He kept " hospitality for his poor neighbours; and somé " alms he gave to the poore; and all this did he " of the sayde farme. Whene he that now hath it " payeth sixteen pounds by the year, or more, and " is not able to doe any thing for hys prince, for " himselfe, nor for hys children, or give a cup of "drinke to the poore "."

This rise of rents, which the bishop states in a manner not remarkable for its precision, does, however, deserve notice. When his father rented the farm in question (in Lincolnshire) at three or four pounds a year, may refer to the time of the battle of Blackheath, fought in the reign of Henry VII., 1497, or fifty years before the sermon was delivered, when the same farm was rented at sixteen pounds or more. This advance in rent, amounting to four or five hundred per cent., must, however, be in some measure apparent

${ }^{1}$ First sermon before King Edward, page 31. Edition of 1575. 
rather than real; because in the interval great alterations had been made in the coin. In the reign of Henry VII. the pound weight of silver was coined into forty-five shillings, twenty of which made a pound sterling. In that part of the reign of Edward VI. in which Latimer preached, for before his death an improvement took place, the coin had been deteriorated, and the pound of silver was coined into seventy-two shillings. The pound of 1497 was worth twentysix shillings and eight-pence in our present money, and the pound of 1548 no more than seventeen shillings and eight-pence, and consequently the advance of rent from four pounds to sixteen pounds nominally, was really from five pounds six shillings and eight-pence to fourteen pounds two shillings, or little more than one hundred and sixty per cent. This is a much more probable rate of advance than what would be inferred from the bare words of the sermon. It corresponds with the contemporaneous increase in the quantity of the precious metals, and with the general advance of price in other commodities.

The bishop was evidently unaware that the influx of gold and silver from the new world was producing a gradual increase of prices, and like other persons in that age sought, with more zeal than judgment, to find the causes of this extraordinary phenomenon. He attributes this, which he treated as a great evil, to enclosures, to sheep walks, to regraters, forestallers, and to any 
cause but the true one, which in his warmth against his neighbours he had totally overlooked, or was unacquainted with.

In uttering his indignation at the advance of prices, he says, "The phisition, if the poore man be " diseased, he can have no help without to much; " and of the lawyer the poore man can get no coun"sell, expedition, nor helpe in this matter, except " he give him to much. At merchants' handes, no " kynde of ware can be had except we give for it to " much. You landlordes, you rentraisers, I may " say you step-lordes, you unnatural lordes, you " have for your possessions yearly to much. For " that here before went for twenty or forty pound " (which is an honest portion to be had gratis in "one lordship of another man's sweat and labour), " now is it let for fifty or one hundred pound by "yeare. Of this to much commeth the monsterous " and portentous dearthe made by man, notwith" standing God doeth send us plentifully the fruites " of the earth, mercifully contrary unto our desertes. " Notwithstanding, to much, which these rich men " have, causeth such dearth, that poor men (which " live of theirlabour) cannot, with the sweat of their " face, have a living, all kind of victuals is so deare, " pigges, geese, capons, chickens, egges, \&c. These " things with others are so unreasonably enhansed, " and I thinke, verily, that if it thus continue, we " shall at length be constrained to pay for a pigge "a pound."

A sermon before a king must be necessarily 
loyal, and the bishop displays no deficiency in that virtue; though, in our day, it may be thought he was somewhat too familiar, especially when recommending the youthful monarch to get a wife. "These graziers, inclosers, and rentrearers," he says, "are hinderers of the kinge's honor: for "where as have beene a great many of housholders " and inhabitants, there is now but a shepeherd and " his dogge; so they hinder the kinge's honor most " of all. My lordes and masters, I say also that all " such proceedinges which are agaynst the kinge's " honor (as I have a parte declared before) and, as " far as I can perceive, doe intend plainly to make " the yeomanry slavery, and the clergy slavery. "For such workes are all singular, private wealth " and commodity. We of the clergy had to much, " but that is taken away, and now we have to little. " But, for myne own part, I have no cause to com"plaine, for, I thanke God and the king, I have " sufficient. And God is my judge I came not to "crave of any man any thing, but I know them " that have too little. There lyeth a great matter " by these appropriations : great reformation is to " be had in them. I know where is a great market " towne with divers hamelets and inhabitantes, where " doe rise years of their labours to the value of fifty "pounds, and the vicar that serveth (being so great " a cure) hath but twelve or fourteen marks by " yeare, so that of this pension he is not able to buy " him bookes, no give his neighbour drinke: all the VOL. II. 
" gayne goeth another way." He farther adds- "In " this realm are a great many folkes, and, amongst " many, I know but one of tender zeale, at the "motion of his poore tenants, hath let downe his "landes to the old rentes for their relife. For "God's love let not him be a phenix, let him not "be alone, let him not be an heremite closed in a "wall: some good man follow him, and doe as he "giveth example."

An act passed at the end of the reign of Henry the eighth, in the year 1545 , which gives some idea of the expense of subsistence in that age, and shows it to have increased, though it is nearly as indefinite as the passages before extracted from the sermons of Bishop Latimer. By that act it is provided, that when the church of any parish whose benefice does not exceed six pounds a year is within a mile of another church, the small parish may be annexed to the other church; but if the parishioners of the small parish shall raise their benefice to eight pounds a year, the annexation may be dissolved. This shows that eight pounds a year was deemed a sufficient remuneration for the services of a parish priest, and enough to maintain him, though it might not enable him to buy books or exercise hospitality, which is the subject of Latimer's complaint.

Whatever may be the rate of advance on the prices of commodities in the period between the first discovery of America and the accession of Edward 
the sixth, it will hereafter be shown, as far as regards England, that it was less than that which occurred in the succeeding period of nearly the same length.

The following table will show what was nearly the advance on prices in France at a period taken about the time of the discovery of America, and at another period about eighty years later. It is extracted and abridged from the publication by Coignard, at Paris, 1746, entitled "Essai sur les Monnois; ou, Réflexions sur le Rapport entre l'Argent et les Denrées."

Year. Article. Price. Year. Price.

1492 setier of wheat

grinding a setier

1494 a pigeon

-

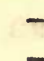

\section{- a pig}

100 herrings

1495 setier of wheat

1499 setier of wheat

1500 setier of wheat

1501 setier of wheat

E. s. $d$.

- a capon

$\begin{array}{llll}0 & 15 & 0 & 1588\end{array}$

\&. s. $d$.

1502 a pound of candles

. $0 \begin{array}{llll}0 & 1 & 2 & 1587\end{array}$

. $0 \begin{array}{llll} & 0 & 6 & 1588\end{array}$

. $0300-$

- 0

- 0

. 01681587

. $0115-$

- 02681588

- $030 \quad 01573$

- $030 \quad 0 \quad 1575$

$\begin{array}{lll}8 & 14 & 0\end{array}$

$\begin{array}{lll}0 & 5 & 10\end{array}$

$\begin{array}{lll}0 & 7 & 2\end{array}$

$\begin{array}{llll}0 & 17 & 0\end{array}$

$\begin{array}{lll}0 & 17 & 0\end{array}$

$\begin{array}{lll}4 & 2 & 0\end{array}$

$\begin{array}{lll}3 & 10 & 0\end{array}$

$6 \begin{array}{lll}6 & 5 & 0\end{array}$

$\begin{array}{lll}9 & 0 & 0\end{array}$

14150

$\begin{array}{lll}6 & 13 & 4\end{array}$

. $\begin{array}{lllllll}0 & 3 & 0 & 1578 & 0 & 19 & 0\end{array}$

$\begin{array}{lllllll}-0 & 0 & 12 & 1587 & 0 & 7 & 6\end{array}$

$\begin{array}{llllllllll}\text { a pint of wine } & . & 0 & 0 & 4 & 1577 & 0 & 3 & 0\end{array}$

— a pint of oil . . $\quad 0 \quad 110-\quad 011 \quad 0$

$\begin{array}{lllllllll}\text { - a voie of fire-wood } & 0 & 0 & 18 & 4 & 1575 & 4 & 15 & 0\end{array}$

$\begin{array}{lllllllll}1503 & \text { a minot of charcoal } . & 0 & 1 & 7 & 1572 & 0 & 8 & 0\end{array}$

$\begin{array}{lllllllll}- & \text { a pound of butter } & 0 & 0 & 10 & 1578 & 0 & 5 & 6\end{array}$

8104

62154

G 2 
This account is given in livres, sols, and deniers, whose proportions to each other are the same as our pounds, shillings, and pence. In France, as in England, the process of diminishing the weight of the livre, which in the time of Charlemagne had been a pound weight of silver, had been constantly going on from 768 to 1720 , when it reached its present or rather its late value of about ten-pence halfpenny sterling.

According to the table, as calculated in the "Traité des Monnoies et de la Jurisdiction de la Cour des Monnoies," published by Bazinghen, 1764 , vol. i. p. 642 , it is shown that the value of the livre, as estimated by the pure silver it contained, was from 1483 to 1497 equal to four livres ten sols of the existing livre, that from 1497 to 1514 it was equal to three livres nineteen sols, and that from 1573 to 1589 it was only worth two livres twelve sols. The preceding table exhibits an advance of prices nearly amounting to seven hundred per cent.; but when the discrepancies arising from the variations in the value of the coin are taken into the calculation, that enormous advance will be reduced down to a rate of increase more consonant to that which appears to have taken place in England at the same time. The advance, instead of being from eight pounds ten shillings and four-pence to sixty-two pounds fifteen shillings and four-pence, will be only from thirty-three pounds nine shillings and nine-pence to one hun- 
dred and fifty-six pounds eighteen shillings and two-pence, or at the rate of nearly four hundred and seventy per cent.

There is good reason to believe that the prices of commodities in the other kingdoms of Europe advanced at nearly the same rate. This is indeed concluded from evidence sufficient to satisfy the author, but which it would be difficult to produce in a concise manner, and would be tedious to any reader to investigate with all the necessary calculations. In Spain there are only to be found in some of the chronicles notices of prices, the weights and measures connected with which, including their variations, as well as those of the money used, are very great. We have, however, the testimony of two Spanish authors of reputed veracity on this subject, which, though expressed in general terms, is deserving of notice. Ortiz says, "The great quantity of gold and silver which fell into the power of the King of Castile caused it to fall to one-sixth of its former value ${ }^{1}$."

Don Sancho Moncada, who published his work at Madrid in 1619, after boasting "de que el oro y plata eran cosecha de esta nacion," adds, "Before the discovery of the Indies, that was to be bought for a quarto which now costs six reals, and he who possessed one hundred reals was as rich as he who now enjoys five hundred; for with

1 Compendio de la Historia de España, vol. iv. p. 413. 
the abundance of gold and silver its value has fallen, and the value of whatever has to be bought with money has likewise increased ${ }^{1}$."

In Italy and Germany, from the number of independent states in those countries, whose coin was in a constant state of change, and varied from that of its next neighbour, and whose weights and measures were equally variable and generally local, it would lead the reader into a wilderness of figures and calculations, which could not be reduced to the simplicity that is to be found in England and France. In those two countries weights and measures have altered but little, and the alterations are easily marked; and the pounds and the livres, though they have diminished in metallic weight, and consequently in effective value, are capable of having that weight and value at any particular period ascertained with tolerable certainty.

1 Restauration de España, p. 211. In Gamboa's "Commentaries on the Mining Laws of Spain," (vol. i. p. 102) is to be found a variety of prices of commodities as fixed by an ordonnance in 1368. We do not quote from them, because the prices are given in maravedies, a money of account, whose value is very doubtful at that period. 


\section{CHAPTER XX.}

Of the effect of the increase of metallic wealth on the various classes of society between 1483 and 1583 .

In the preceding chapter we have attempted to show the influence exercised on the mass of commodities by the increased supply of the precious metals which the discovery of America had yielded; and that within the first century after that event the quantity of those metals had increased nearly fivefold, and the prices of commodities in the same period been enhanced in nearly the same proportion.

It is now desirable to examine into the effect produced on the several classes of society by a course of events which were so new to the generations who lived during the century in which this cause first exhibited its operations.

The silence of most contemporary writers on the subject, or the allusions casually made by a few of them, show that the advance of prices made but a slight impression during its progress. It was not till the end of twenty or thirty years that those who looked backwards with attention became sensible of the great addition that had been made to them. It is to be remembered that to increase fivefold in one hundred years, it is not 
necessary that the increase should on the whole course of those years be at the rate of five per cent. annually. Every addition would reduce the ratio of the succeeding addition, acting as compound interest does on money. If we take as an example the sum of all commodities to be ten millions of pounds, and add to it two per cent. the first year, and to the sum so obtained, ten million two hundred thousand pounds, at the end of the second year, with the addition of two per cent., will be ten million two hundred and four thousand pounds. In this way the prices of the commodities would be double, or twenty millions, in somewhat less than thirty-six years. In the next thirtysix years, at the same ratio of addition, the prices would be again double, or forty millions. The next twenty-eight years would be more than sufficient to raise the prices of the commodities to five times as much as at the beginning of the hundred years.

This view of the subject, thus expressed so as to make it intelligible without any algebraic operation, seems necessary to account for the little notice taken of the great advance in prices between 1483 and $1583^{1}$. An advance of somewhat less than two per cent. is scarcely perceptible till some years have elapsed; and those who do happen to observe it would be satisfied by attributing it to some local or temporary cause, rather than to so distant an

${ }^{1}$ The exact annual addition of $1 \frac{5}{8}$ per cent. to any sum will in one hundred years increase the original sum fivefold. 
operation as the increased production of mines in a country so remote that even their existence may be unknown.

It would naturally be imagined, at a time when money was looked upon almost exclusively as wealth, that an addition to it would have been hailed with joy - that every individual and each community would have been gladdened at the knowledge that they were becoming more rich than they had before considered themselves. The very reverse of this, however, appears to have been the case, and complaints of distress were never so frequent nor so loud as at the period we are now referring to.

A valuable work on this subject was published in the reign of Elizabeth, in the year 1581, entitled "A Briefe Conceipte touching the CommonWeale of this Realme of England." It is in the form of a dialogue between a knight, a landholder who had served in parliament, a husbandman a tenant to the knight, a merchant or shopkeeper in a large town, a manufacturer of caps or hats of the same place, and a doctor of divinity. The dialogue is carried on with intelligence, with urbanity, and with views appropriate to the respective characters of the speakers. The author, said by Watt to be a William Stafford ${ }^{1}$, displays

1 The name in the title-page in the black-letter copy is "W. S., Gentleman." Nothing certain is known of the author, but a bookseller in 1751 reprinted the "Conceipte," 
much knowledge of the state of the country generally, and of the change that was then going on in the relations of the several classes of society to each other.

This work, published about thirty years after the sermons of Latimer, from which quotations have been presented to the reader, repeats and extends the complaints which the pious prelate uttered, and introduces a picture of future decay in England which rivals that of the bishop.

The quaint language and the ancient and unfixed spelling in this work will need no apology with any reader, and the phraseology is much more appropriate to the period it describes than any sentences would be if constructed in more modern English. We give the complaints, therefore, in their own words, though not exactly in the order in which they stand in the dialogue. The knight says, -

"All of my sorte-I meane all gentlemen-have "greate cause to complayne, now that the pryces " of thinges are so risen of all handes that you " may better lyve after your degree than we; for " you may and do rayse the pryce of your wares as

and ventured, without authority or truth, to insert in the titlepage " By William Shakespeare, Gent.," doubtless thinking the name of the great poet would sell the work. As Shakspeare was born in 1564, and could be only seventeen at the time of the publication, it is next to impossible he could have been the author of a work containing so much accurate knowledge. 
"the prises of vittayles and other necessaries doe "ryse, and so cannot we so much; for though it " bee true, that of such landes as come to handes " eyther by purchase or by determination and ending " of such termes of yeares that I or my ancestors " had graunted them in time past, I do receyve a " better fine than of old was used, or enhaunce the " rent thereof, being forced thereto for the charge " of my household, that is so encreased over that it "was; yet in all my lyfetyme I look not that the " thyrd parte of my land shall come to my disposition, " that I may enhaunce the rent of the same, but it "shall be in men's holding either by leases or by " copy graunted before my tyme, and still con" tinuing, and yet lyke to continue in the same state "for the most part during my lyfe, and percase my "sonnes : so as we cannot rayse all our wares as " you may do yours, and as me thinketh it were " reason we did ; and, by reason that we cannot, so " many of us as (yee know) that have departed out " of the country of late have bene driven to give " over our households, and to keepe eyther a cham" ber in London, or to wayte on the court uncalled, " with a man and lackey after him where he was " wonte to keepe halfe a score of cleane men in his " house, and twenty or twenty-four other persons " besides every day in the weeke, and such of us as " doeabyde in the country still cannot with two hun" dredth a yeare keepe that we might have done with "two bundred markes sixteen yeares ago."- - We 
" are forced, therefore, to minish the third part of " our householde, or to rayse the third part of our " revenewes, and for that we cannot so doe of our " owne landes that is already in the hands of other " men, many of us are enforced either to keepe " peeces of our owne landes when they fall in our " owne possession, or to purchase some farme of " other men's landes, and to store it with sheep or "some other cattel, to help make up the decay of " our revenewes, and to maintayne our olde estate "withall, and yet all is little ynough."

The husbandman is not without his causes of complaint, though he evidently had less reason for them than his landlord. Instead, however, of proving his actual state to be bad, he dwells much on the causes of the suffering which he pretends those of his class are subjected to. He says- "These " inclosures doe undoe us all, for they make us to " pay dearer for our land that we occupy, and causes " that we can have no land in manner for our money " to put to tyllage, all is taken up for pasture-for "pasture eyther for sheepe, or for grasing of cattell " - in so much that I have knowne of late a dozen "ploughes within less compass than six myles about "mee layde down within this seven yeares: and "where threescore persons or upwards had their "livings, now one man with his cattell hath all, " which thinge is not the least cause of former up" rores; for by these inclosures many doe lack livings " and be ydle, and therefore for very necessity they 
" are desirous of a chaunge, being in hope to come " thereby to somewhat, and well assured that, howe "so ever it befall with them, it can be no harder " with them than it was before: moreover, all things " are so deere that by there day wages they are not "able to lyve. Those sheepe is the cause of all " these mischieves, for they have driven husbandry " out of the country, by the which was increased " before all kind of victailes, and now altogether " sheepe, sheepe, sheepe. It was farre better when " there were not only sheepe ynough, but oxen, kine, "swyne, pig, goose, and capon, egges, butter, and " cheese, yea and bread-corne and malt-corne ynough " besides, reared altogether upon the same lande."

The manufacturer of hats also, in his turn, takes up the same lamentations. He agrees with the farmer, and confirms it by his experience ; "For," says he, "I am faine to give my journeimen two " pence in a day more than I was wont to doe, and " yet they say they cannot sufficiently live thereon. "And I know for truth that the best husbande of " them can save but little at the yeare's ende. And " by reason of such dearth as yee speake of, we that " are artificers are able to keepe few or no prentizes, "like as we were wont to doe, and therefore cities " which were heretofore well inhabyted and wealthy " (as yee knowe every one of you) are now, for lacke " of occupiers, fallen to great poverty and desolation. "It was never merry with poor craftsmen since gen" tlemen became grasiers, for they cannot now a 
" dayes find theyr prentizes and servants meate and " drynke, but it cost them almost double as much "as did before time; wherefore were many of " myne occupation and other like heretofore have "dyed rich men and been able to leave honestly " behinde them for thyr wife and children, and be"side that leave some notable bequest for some "good deede, as to the making of brydges and " repayring of high wayes, all of which thinges goe " to wracke now every where. Also some were wont " to buy lande eyther, for to help the poore be"ginners of the occupations : yea, sometimes they " had such superfluity as they could, over such be"quests, leave another portion to finde a pryste, " or to found a chauntry in some parish church; " and now we are askant able to live without debt, " or to keep few servants or none, except it be "one prentize or two. And therefore the jour" neymen, what of our occupations and what of " clothyers, and all other occupations, being forced " to be without worke, are the most parte of these " rude people that maketh these uprores abrode, " to the great disquiet not onely of the queene's " highnes, but also of her people."

The merchant complains in a similar manner, and, affirming that poverty reigns in all the towns of England except London, and that their houses, streets, walls, bridges, and roads are hastening rapidly to decay, continues to pourtray it in the following words :- 
" Albeit there be many things layde downe now "which before time were occasions of much ex"pences, as May-games, wakes, revels, wages at " shootinge, wrestling, running, throwing the stone " or barre, and, besides that, pardons, pilgrimages, " offrings, and many such other thinges, yet I per" ceyve we be never the wealthyer, but rather the " poorer: whereof it is long, I cannot well tell, for " there is such a general dearth of all thinges as "before twenty or thirty yeares hath not been the "like-not onely of things growing within this " realm, but also of all other marchaundize that we " buy from beyond the sea, as sylkes, wynes, oyles, " woode, madder, yron, steele, wax, flaxe, lynen" cloth, fustyans, worsteddes, coverlets, carpets, " and all hearses and tapestry, spyces of all sortes, " and all haberdasher ware, as paper, both white " and browne, glasses, as well drinking and looking " as for glassing of windowes, pinnes, needles, " knives, daggers, hats, broaches, buttons, and "laces. I wot well all these doe cost nowe more "by the thyrd part than they did but few yeares "ago. Than all vitayle is as deere or deerer agayne; " and no cause of God's part thereof, as farre as I " can perceave, for I never sawe more plenty of " corne, grasse, and cattell of all sorte than we " have at this present, and have had (as yee know) " all these twenty yeares passed continually, thanked " be our Lord God. If these inclosures were cause " thereof, or any other thinge els, it were a pity "but they might be removed." 
The doctor seems the most rational man of the party; for though at first he also complains, it is with more moderation, and chiefly on the evils which had arisen from differences of religious opinions, which he contends have been chiefly inflicted on the most honest and conscientious members of his profession.

"Yee knowe well," he says, " though we have "least cause to complaine, we be not so plenteous " as we have bene: the first-fruits and tenths are " deducted of our livings; yet of the rest we might " live wel ynough, if we might have quietness of " mind and conscience withall. Marry have you " not seen how many learned men have bene put " to trouble of late, within this twenty or thirty "yeares, and all for declaring their opinions in " thynges that have rysen in controversy? Have "you not knowne when one opinion hath bene "set forth, and who so ever said against that was "put to trouble? And shortly after, when the " contrary opinion was furthered and set forth, "were not they that prospered before put to " trouble for saying their minds against this latter "opinion? And so neither of both parties " escaped, but, eyther first or last, came to be hit, " of whether side so ever he were, except it were " some wetherwise fellowes that could chaunge " their opinions as the more or stronger part did " chaunge theirs."

The capper, who seems to have thought but lightly of either religion or learning, frankly tells the 
doctor his opinion on his profession, saying, "If "I were of the queene's counsell, I would set you to "the plough and carte, for the devil a whit of good "yee doe with your studies but to set men together "by the ears, some with this opinion, and some "with that, some holding this way, and some " another, and that so stiffly as though the troth " must, as they say that have the upper hand in con" tencion; and this contencion is not also the least " cause of former uprores of the people, some " holding of the one learning, and some of the " other. In my minde, it made no matter though "we had no learned men at all."

The knight objects to this opinion, and very properly asks, " if we had no learned men, how "should the prince have counsailors? how should "we have Christian religion taught us? how " should we know the estate of other realmes, and " have conference with them of all countryes, " except it were through learning, and by the " benefit of letters?"

The capper, after some observations from the doctor, concedes to this view taken by the knight, and says, "I meane not but I would have men to "learn to wryte and reade, yea, and to learne the " languages used in countrys about us, that we " might tell our minds to them and they to us, yea " and that we might reade the holy scriptures in " our mother tongue; and as for your preaching, "(except yee agree better) it made no matter how 
" little we had of it, for of diversity thereof cometh " those diversities of opinions."

In concluding this part of the subject the knight sums up that in which all agree, "that the " griefes standeth in these poynts, a dearth of all " things in comparison of the former age, though " there be scarceness of nothing; desolation of " countryes by enclosures; desolation of townes for " lacke of occupations and craftes; and division of " opinions in matters of religion, which haleth " men to and fro, and maketh them to contend " one against another."

After the picture thus presented, in the words of a cotemporary artist, we will now examine what was the actual effect of this vast increase of money in the century which closed at the time of the publication of the "Briefe conceipte." It seems clear that the advance of price on all the commodities that were bought and sold must have been alike, except as regards articles whose prices were affected by peculiar temporary or local causes. The same quantity of cloth would purchase a hat or a gown; the same measure of corn, except in years of extraordinary scarcity or abundance from the state of the harvest, would procure a sheep or a cow. The value of all commodities would bear the same relation to each other as if no change in the quantity of money had existed. The only alteration would be on the medium, by means of which the proportions between different 
kinds of articles were adjusted. When any commodities were sold, the buyer would complain of the quantity of money he must pay, and that would leave a deep impression on his mind, which would not be removed by the higher price he would obtain for what he sold. All would wish to buy cheap, but to sell dear. The gratification of the last wish is more than destroyed by the nongratification of the first. This was evidently the case with the individuals whose views are described by themselves in the dialogues. Every one who produced more than he consumed would find at the end of a few years that his wealth, estimated as wealth commonly is in money, had increased considerably beyond his expectation. Every one who consumed more than he produced would in a few years find that his wealth, estimated in the same manner, had diminished more than he had anticipated. This condition of the two classes would have a beneficial effect on the aggregate wealth of the community. The producers would be encouraged to more strenuous exertions, and the consumers would be induced to adopt a greater degree of parsimony. That portion of society who are both producers and consumers, and they are probably by far the largest class, would find little or no alteration in their condition, except as far as the small difference on the excess of their production over their consumption, or the contrary, which in most 
cases would be small. Whilst this process of the declining value of money was going on, those who were in debt would discharge the demands upon them, in proportion to the length of credit, with considerable gain; whilst, on the other hand, the creditors would receive payment in money of less value than that at the time when they had given the credit. In this case, taken thus, the creditor would suffer a loss, and the debtor would have a gain ; but as commonly the "borrower is servant to the lender," the latter would be more than indemnified by taking a rate of interest so much higher as to cover the anticipated decline in the value of money; for after a few years of the course here supposed all would act from analogy, and upon the principle that as commodities had been gradually increasing, so they would continue to increase, or, which is the same thing, that the value of money would continue to decline. Thus Bishop Latimer, preaching in 1548, anticipated that before long a pig would be worth a pound, an expectation that was verified when the "Conceipte" was written, in $\mathbf{1 5 8 1 .}$

This mode of acting, if not of reasoning, from analogy is the most influential and the most universal, and to it we owe the regular succession of agricultural labours; for the farmer ploughs and sows on no other principle but that because the summers of past years have brought his corn to perfection, so that the next summer will produce 
the same effect on the labour on which he is engaged at every seed time. The same mode of acting on analogy would be applied to other operations of industry. The weaver would perceive that cloth had been constantly rising in its money price; he would conclude it would continue to rise, because it had done so; and this would quicken his exertions, and induce him to bring more cloth into the market. The same would be the case with the producers of other articles, and thus an impulse would be given to the productive powers, which would continue as long as the increase of the precious metals should continue to lessen their relative value to other commodities.

There seems no other way in which the increase of the gold and silver can be beneficial to a whole community. The intrinsic value of it bears but a small proportion to the various other kinds of wealth which communities possess, and the value of it, like that of all other commodities, is regulated by the common principles of supply and demand.

It is probable that in all ages those metals have cost more in their production than their value ever repaid. And if the amount of human sufferings in the earlier ages of the world could be reduced to a money valuation, and to them were to be added the evils derived from them by their derangement of existing conditions in society, it would become doubtful if the increase of industry, which at particular periods has been caused by it, has been 
more than a balance to the misery they have occasioned.

This is, however, a view which it becomes necessary to turn aside from, and look at those derangements which were occasioned among different classes by the great influx of the precious metals in the first century after the discovery of America.

The several monarchs who ruled in the different divisions of Europe were commonly the largest proprietors of the land in their dominions, and chiefly subsisted on their produce, which was transferred to them partly in kind, partly in various feudal services, and partly in money. The portion paid in money was chiefly in the form of fines at the renewal of leases, with small fixed annual rents, which were in many cases almost nominal, or. which became so when the value of money declined. In England a pepper-corn rent was common, but it originated at a time when that spice was of more than five hundred times its present value if exchanged for silver, and perhaps five thousand times that value when exchanged for corn or wool.

In time of war our monarchs obtained money from their subjects under various names and pretexts, but in peace chiefly depended on their lands, with some addition from the customs and from the coinage. The latter was made available by Henry VII. and Henry VIII. to an extravagant extent, and by Edward VI. till the 
last year of his reign. In the reign of Mary her demands were in some measure supplied from the treasures of her husband, Philip of Spain. Elizabeth, who placed confidence in enlightened ministers, was led to avoid the evil of debasing the coin, and in the latter years of her reign placed it on a proper footing, which has been continued ever since with slight variations. The rigid frugality she practised, her abstinence from wars, and the high tone of authority which she exhibited to her parliaments, preserved her from pressing on her subjects, who from a feeling of loyal attachment were ever ready to satisfy her demands. During these reigns the income derived by the crown from the lands had been very little increased, whilst all the expenses of living, whether laid out for foreign or domestic commodities, had been raised to at least four or five times as much as a hundred years earlier. It is then evident that the wealth as well as the power of the crown must have diminished very considerably in the period we are reviewing.

It does not indeed seem improbable that the continued increase of expenditure, whilst a great part of the royal income was stationary, was one of the causes which produced the civil wars in the reign of Charles I., and at length cost the loss of his life to that unfortunate monarch.

The condition of the proprietors of the soil naturally attracts attention next to that of the sovereigns. Where the rent was paid in produce, 
and that produce was partly consumed in their households, they would be benefited to the extent of the increased price of that surplus which was to be sold, provided such surplus amounted to more than the cost of the foreign commodities which they might purchase. If their estates were let out, as was mostly the case, to tenants for lives or for a long term of years, the fines on renewals as well as the rents would be fixed at the commencement of the leases at the value of money of the period when they were granted, and during the currency of such leases the landlord would receive less than the value of his land by receiving payment in money which was depreciating from year to year, as additions were made to the stock of gold and silver. As far as regarded the demesne lands in the occupation of the proprietor, whether such lands were in tillage or in pasture, and especially in the latter case, the profit of the possessor on what he sold would be annually increased by the declining value of the precious metals in which he would be paid for his produce.

Whenever an estate was charged with incumbrances either of the nature of mortgages or of settlements on the other branches of a family than the possessor of it, or for pious or charitable purposes, the annual depreciation of money would tend to relieve it of the burden, and with a greater or less degree of rapidity, according to the length of the terms of the leases under which its parts may have been granted out to tenants. 
From what has been already stated of the effect of the depreciation of metallic money on the condition of the proprietors of the soil, it is natural to proceed to that of the real cultivators, the operative husbandmen. England presents a picture of this class in society which, with the exception of a part of the Netherlands, is to be seen in no other country on the globe, and to which perhaps it is indebted for its peculiar advantages, both social and political, in a greater degree than to any other single cause.

The system of cultivating lands on a kind of partnership plan prevails almost universally; the landlord supplying the cultivator with the requisite stock of cattle and implements, and receiving a stipulated share of the produce, either in kind, in labour, or in money, instead of what we denominate rent. Whether this system be a continuation of that practised by the Greeks, afterwards by the Romans, and handed down since their dominion has ceased to the French, the Spaniards, the Italians, and in some degree to the Germans, under the names of the Metayer or Meyer system, it has not, happily for Great Britain, been much if ever known in this island.

It is not designed here to enter into an examination of the effect of the various modes in which the owners of land have arranged with the cultivators in different countries. It is a large field of inquiry, which would lead too far from the immediate object under consideration. It is besides the 
less necessary, because in a work lately issued from the Cambridge university press more facts are collected on the subject of rent than are to be found in any other work, accompanied with the most judicious observations on the advantages and disadvantages of the different modes by which it is extracted ${ }^{1}$.

The cultivators in this country, at the period we are considering, were under contracts with the proprietors of the soil to pay certain small annual money payments. Those payments were fixed at the commencement of the term for which the leases were granted, the greater part of which were for ninety-nine years, but determinable after the death of three lives. A fine was almost universally paid on the granting the lease, and as each life dropped a fine was paid for a renewal.

It seems almost certain that the fine as well as the annual, or, as it was commonly called, " the lord's rent," was fixed with reference to the rate of prices which the produce bore at the commencement of the term. The first term when a renewal would become necessary, on the death of the first of the three lives, would be about thirty-three years. A fine would then be demandable for a new

1 See An Essay on the Distribution of Wealth and on the Sources of Taxation-Part.lst, Rent-by the Rev. Richard Jones, M. A. of Gonville and Caius College, Cambridge. 
life. Supposing produce to have risen as we have shown it did in the period, at the rate of a hundred and fifty per cent., the value of the new life to be placed in the farm would have been much more than saved by the advance of prices, whilst the rent had remained unchanged. In this way tenants of the description here noticed would with prudence and care have saved more in the course of a century, during which prices had gradually advanced to five times their former rate, than would be sufficient to purchase their own farms.

By this view of the subject we see that the cultivators in England became capitalists, and if they chose rather to rent than to buy land, were enabled to provide from their capitals the necessary stock of cattle and implements, and to furnish the sums required to pay their labourers till the fruits of their industry should arrive at maturity, and become applicable to that and the other purposes of cultivation.

It is difficult to account for the different course which rural affairs assumed in England from what at the same period presents itself to our view on looking at the continental kingdoms, where the operative cultivators became metayer occupants, and have entailed on their successors all the evils which seem inseparably connected with that system, and which are the greater evil from the difficulties which oppose its amelioration.

Much of this difference may be attributed to our insular position, and to the security to pro- 
perty so much exposed as that of the cultivator is, which is derived from that cause. After the termination of the wars between the houses of York and Lancaster, England remained in a state of internal tranquillity. The wars with Scotland were mere border warfare, and the effect of them was scarcely felt except in the northern counties. The internal disturbances in Norfolk, in Devonshire, in Yorkshire, and some other parts, were local and transient; and taking the whole of the period from the ascession of Henry VII. to the civil war in the reign of Charles I., England may be said to have enjoyed such domestic peace as was quite sufficient to give general security to property and general confidence in its continuance. Whilst thus for more than a century and a half, during the period in which the greatest advance in prices had been making, no hostile foot had trodden the English soil that could put the labours of the cultivators in jeopardy, and whilst one monarch ruled the whole kingdom, the countries on the continent were desolated by continual wars, and their internal arrangements subject to constant disruptions from the number of petty sovereignties into which they were divided. France indeed, at the early part of the period, had been enabled to unite into one kingdom the dukedom of Britanny, the earldoms of Provence and Daupheny, and the kingdom of Navarre ; but the civil wars on account of religion, and the state of internal disquiet which extensively prevailed, ren- 
dered all property which, like that of the produce of the soil, could be serviceable to hostile bodies extremely insecure. Italy and Germany were divided into such a great number of separate sovereignties perpetually at variance with each other, that any property exposed in the fields or the villages was constantly liable to military seizure.

In those countries the operative cultivators must have been benefited by the advance of prices, such at least of them as escaped the rude hands of the military depredators; but their experience must have warned them from investing it in agricultural stock and implements, and they could have had no occasion to expose themselves to such hazardous experiments when the landowners were quite ready to furnish stock, and thus incur all the risk, whilst the cultivator was to be a sharer of the benefit. Other causes may have contributed to give to English agriculture that peculiarly beneficial direction which it received at the period when the influx of the precious metals had its greatest influence on prices. It is, however, grateful to our feelings to trace the rise of a class in society which is known in no other country, that of capitalists cultivating the lands of proprietors, paying fixed sums for the use of the lands, and exercising their skill and industry for their own benefit in the first instance; for the benefit of the proprietor, if he be a wise and good landlord; and for the benefit of 
the community; which is more copiously and regularly supplied with all the products of the soil, and on more advantageous terms, than by any other known system.

If the mere labourers in agriculture be looked at, it is to be feared that their condition will not appear to have been benefited by the great advance of prices. The rates of wages to day labourers do not seem to have risen in the same proportion as the necessaries of life, and the laws passed under Elizabeth for the relief of the poor are sufficient evidence of their wretched condition. It may deserve some slight investigation, not certainly with a view to any benefit to the same class in the present day, whose whole circumstances are so totally different, but to account for the undoubted fact at the period now under consideration.

In consequence of the great advance of prices, each cultivator was solicitous to fix on objects whose produce would sell most readily, and for the highest prices. The extension of the woollen manufactory in England, and the great demand for English wool in Flanders, had raised the price of that product at a much greater rate than was experienced in corn and other vegetable substances. The conversion of arable land into sheep walks, which was the common subject of complaint, and forbidden by laws enacted for the purpose, caused a diminution of the demand for labourers, and that in two ways: a flock of sheep required few 
servants, and the manure they supplied made the corn land more productive, so that with a much smaller portion of labour a quantity of corn was raised quite equal to the wants of the community. Though manufactures were increasing, they could not absorb the surplus of rural labour. The privileges of guilds and corporations, and the rights of journeymen, which excluded all who had not served apprenticeships, were obstacles to the employment of the agricultural labourers, not to notice that in general they were ill qualified for such occupations. Another cause from which the poor suffered arose from the condition of those landed proprietors whose estates were let at long leases, who found when every article they consumed was doubled or tripled in price their incomes remained unaltered. They were compelled to diminish their establishments, and as the mode least painful was the dismission of their useless or cumbersome domestics, we find constant complaints of the numerous serving men who wanted occupation.

The manufacturers of the period must have been in prosperous circumstances. Every raw material was rising, but still the demand was increasing. What was dear when purchased became still dearer by the operation of the mines, and was felt in the sale of it. In the present day the process of manufacturing by machinery gives such rapidity to the whole operation, that there is scarcely time for a 
gradual advance to take place between the commencement and the completion of a piece of cloth ; but in that day, when machinery was unknown, and the division of labour was not carried to the present minute extent, the making a piece of cloth occupied more months than it does now days. At this slow rate the general increase of price of all commodities would insure a profit by the delay, in addition to the regular profit on the manufacture.

The merchants, whether wholesale or retail, whether confined to the home or extended to the foreign trade, must have benefited in proportion to the stock of goods they kept in their warehouses and their shops. The dealer in a rising article necessarily gets money, because the rise, whatever it may be, comes in addition to the regular profits of his trade.

The navigation of the European world was much extended in this period, and though it was but trifling compared with the extent to which it has been since carried, yet, as far as it had proceeded, it increased the wealth of the merchant adventurers who engaged in it, and added additional and important members to that class of society.

The effect of this prosperous state of the operative cultivators, of the manufacturers, and of the merchants and retail traders, has been prolonged through more than three centuries, and has given to European society in general, but to that of England more especially, a form utterly unknown 
in the ages which had preceded the discovery of America. It has given rise to a class of persons properly denominated the middle order, who possess the greater part of the wealth, the activity, the intellect, and the influence in those parts of the world whose position and connexion and civilization may be said to rule the globe.

Although the quantity of the precious metals produced from the mines was less in the period we have surveyed than in each of the two centuries which succeeded it, yet it is of much importance to the purpose of this inquiry. The quantity introduced acted upon the small quantity previously in existence with most powerful effect. It quadrupled or quintupled the portion of money. It lowered its value as a commodity in the same proportion; or, in other words, it raised the value of all commodities at the rate here stated. In subsequent periods, it will be seen that the larger quantities of gold and silver that were extracted from the mines produced much less effect, because they acted upon the larger portions which had previously been accumulated.

In fact, in no period of the world was the change in all mercantile and agricultural relations and connexions in any degree approaching to that which took place between the termination of the fifteenth and of the sixteenth century. In the next century, though more of the precious metals was produced, the change was less extensive; and 
it was the same in the century between the years 1700 and 1800 , though the mines yielded still more. It is to fix attention on this great change that such an extended view of the several classes of society who were interested in it has been taken. Its effect has been felt in every quarter of the globe, and has had an influence on the prosperity of the whole civilized race of man-not by the wealth that the gold and silver amounted to, but by the stimulus it began to administer to every branch of industry, by the impulse it communicated to physical, mechanical, legislative, judicial, and even moral investigations, and by the attachment it inspired to the sound principles which introduced legal, civil, and political freedom. 


\section{CHAPTER XXI.}

On the increase of metallic wealth, and the proportionate increase of material wealth, between the years 1600 and 1700 .

IN the continuance of this inquiry, as far as relates to the produce of gold and silver from their chief source the mines of America, the progress will be both clear and easy. The facts and calculations of Baron Humboldt are presented to the public after so much consideration, and accompanied with so much discrimination and impartiality, that they may be in most cases implicitly adopted. His account of the produce of Mexico will be followed till the year when the documents procured by Mr. Ward, then his majesty's minister to that country, commences. These come down to the end of the year 1825, and being collected from official sources ought to be and probably are the most correct that could be obtained. 'The few years that follow to the end of 1829 are supplied from sources of various kinds-some from reports to the assemblies of the republic, and some from communications made by persons resident in Mexico employed by the English mining-companies. In these last though there are some discrepancies which it may be difficult to reconcile, their amount is so insig- 
nificant that an error cannot exist to an extent which would make a difference in the whole calculation of two per cent.

Peru. Although there was much fluctuation in the produce of the American mines during the seventeenth century, yet upon the whole there was an increase, though not a large one. The mines in the district of Potosi in Peru had declined to a great extent. In the first fifteen years of the century they had yielded one million six hundred and seventy thousand three hundred and forty-four piastres, or about three hundred and fifty thousand pounds; and in the last fifteen years, from 1685 to 1699, both years inclusive, the average amounts to no more than five hundred and fifty-nine thousand nine hundred and forty-three piastres, or about one hundred and sixteen thousand six hundred and sixty pounds. At the first discovery of that mass of mineral wealth, the Spanish conquerors exercised the most unlimited power over the natives. They were driven to the severe labour of the mines in a cold and inhospitable climate, where subsistence was difficult to be obtained; and the change from the deep and warm and fruitful valleys where they had passed their time in tranquillity and abundance swept them away in great numbers. The interference of the government of Spain, which sent commissioners and strict orders to mitigate the lot of the natives, was ineffectual: the rude adventurers who had conquered the 
country thought little of the obedience due to a power so remote and inactive as that which ruled in the European peninsula. The waste of the indigenous population was attempted to be supplied by the importation of negro slaves from the African shores; but this inhuman resource was far from effectual. The voyage to the river Plate, with the journey over the Pampas and the Cordilleras, lessened the numbers of the captives and weakened the frames of those who arrived at the inhospitable cerro of Potosi, and when there the severity of the climate rendered most of them incapable of labour.

As the country between La Plata and Peru be- Buenos came more traversed, districts were discovered of great natural fertility and salubrity, and establishments were formed near veins of minerals, which upon more mature examination were found to contain much silver and some gold. The negro slaves were applied to those operations, as well as the few native labourers which the scanty population could furnish. In this way the country then considered a part of Peru, but separated from it in 1788, and added to the viceroyalty of Buenos Ayres, and since under the revolutionary regimen converted into a kind of independent republic called Bolivia, with Cuzco for its capital, became peopled, cultivated, and productive of the precious metals. In a few years mines were opened and worked in Carangas, Oruro, Andacava, and Chaquiapu 
(since called $\mathrm{La} \mathrm{Paz}$ ); and their operations were quickened by the stimulus arising from the desire to procure the maté or tea of Paraguay, which silver could most easily purchase, and which was deemed an indispensable refreshment for those who laboured in the mines.

Northern Peru.

In the same century the silver mines of Yauricocha or Pasco, in' the more northern part of Peru, were first opened, and yielded a large portion of that metal. It is thus that though Potosi, which had at first yielded the greatest quantity of silver, had declined, yet the other parts of Peru advanced in their issue of the precious metals so considerably as more than to compensate for that deficiency. This increase, especially of silver, was greatly facilitated by the extension of the mines of mercury at Huancavelica. Those mines, as has been before noticed, were discovered as early as the method of extracting silver by the process of amalgamation in 1576 ; but the quantity at first produced was small when compared with that which they reached between the years 1598 and 1684, after which they appear again to have declined. The quicksilver was under monopoly regulations, the government making the delivery of it subservient to its purposes in securing the tax on the silver; so that the quantity which each miner received was a kind of check on the quantity of silver on which he ought to pay the tax or the king's share.

The chief of those mines became choked up about 
the year 1790 , which was a real calamity to the mining-interests in South America. The superintendant of that day removed the pillars which had been left by the excavators of the galleries to support the roof. By the superincumbent pressure the roof fell in, and the passages became blocked up. "The master miners," says Humboldt, "accused the intendant of having removed the pillars to ingratiate himself with the court of Madrid, by procuring in a very few years a great quantity of mercury. The intendant on his part affirmed that he had acted altogether with the consent of the master miners, who thought the pillars might be replaced by heaps of rubbish." This calamity is only noticed to show how difficult it must have been for the government of Spain to have directed the important affairs of their very remote possessions, and must form an apology for many instances of their mismanagement, if any other apology be needed than the infinitely worse management which has been adopted since those countries have had the task of self-government inflicted on them by their applauded liberators.

Whilst the increase of silver was advancing in Peru, that of gold was also going on in South America, in the countries to the north and south of that viceroyalty. In Chili both the Spaniards Chili. and their dependent Indians, with the unconquered Arucanians to the south of the river Biobio, were sedulously employed in washing for gold in those 
streams which descend from the Cordilleras. The climate is mild and the soil fruitful; and perhaps less suffering was inflicted in the extraction of that than of any gold or silver in the other times and countries where it has been acquired. A recent traveller who has visited Chili remarks, "It is usually observed in those countries where great mineral riches exist, that the soil is of a barren and unproductive nature; but Chili affords a striking and solitary exception to this rule. Streams abounding in gold wander through the most luxuriant corn-fields, and the farmer and the miner hold converse together on their banks ${ }^{1} . "$

In the northern part of South America, formerly known as the new kingdom of Granada, but now forming what is denominated the Republic of Columbia, some little silver, but much more gold, was produced. The first conquerors found gold in Barquisemento, and in some other places in the mountains to the north-east of the nevada of Merida, and in those to the south of Caraccas, but they appear to have been very early exhausted. In the century now under consideration, the chief quantity of gold was procured from the valleys or ravines in the mountainous regions of Antioquia, in the valley of Cauca, between the central and western Cordilleras, and especially in the province of Popayan, at its southern

${ }^{1}$ Caldcleugh's South America, vol. i. p. 351. 
extremity. Some was also found, but only towards the latter end of the seventeenth century, in the province of Choco; which afterwards yielded, in proportion to its extent, a greater quantity of that metal than any other part of the globe, though its climate is one of the most unhealthy in the whole of America.

The chief increase between 1500 and 1600 was of silver from the viceroyalty of Mexico, where Mexico. the production of Zaccatecas, Guanaxuato, and the other mining-districts had advanced from the value of two million piastres to that of five millions, and at the latter part of the century had far exceeded that annual average.

Although when the Spaniards conquered Mexico they appear to have annihilated the higher classes, yet the population which was left was quite sufficient to supply labourers, and recourse was never had to the cruel and costly practice of importing negroes from Africa to execute the most servile part of the work, as had been done in Peru, Buenos Ayres, and Columbia. The introduction of cattle and of vegetable productions from Europe, which had been unknown before in Mexico, afforded abundance of subsistence; and if the population did not increase it did not greatly diminish under the Spanish yoke. The feudalism which was found in Mexico was rather of a paternal than a slavish character; and the same system was continued by the new proprietors of 
the soil. Labourers were easily procured for the mines by the assistance of the native caciques, who were always ready to send their vassals to the spots where mines were opened, who either worked below the surface for the metals, or cultivated the land to raise food for those who performed that labour, whilst their hereditary superiors drew some gain to themselves from the employment of those of their respective clans. Humboldt asserts that in the time he visited Mexico the work of the mines was executed alone by free labourers, and the knowledge obtained since a more constant intercourse has been admitted confirms the assertion.

Whatever the health and strength of those natives of Mexico who inhabited the moist and sultry plains may have been, it seems that those who live on the elevated levels are far better adapted for severe labour, and far more capable of enduring continued exertion, than any of the tribes that have been carried from Africa to America. The burdens these men are now in the habit of carrying on their backs up a steep ascent from the bottom of the deepest mines to the surface excite surprise in Europe, where such labour is almost exclusively performed by machinery. "The Indians, Tenateros," says Humboldt, "who may be considered as the beasts of burden of the mines of Mexico, remain loaded with a weight of from two hundred and fifty to 
three hundred and fifty pounds for a space of six hours. In the galleries of the mines (Valenciana and Rayas) they are exposed to a temperature of from $71^{\circ}$ to $77^{\circ}$ of Fahrenheit, and during this time they ascend and descend several thousand steps in pits of an inclination of $45^{\circ}$."

"We meet," he says, "in the mines, with files of fifty or sixty of these porters, among whom there are men above sixty and boys of ten or twelve years of age."

The labour of this hardy race had been directed to the mines from the period when the Spaniards had accomplished the quiet submission of the country. It was employed in numerous small mines till about the beginning of the seventeenth century. But in or about the year 1630 the mines of Guanaxuato began to be opened, or perhaps only greatly extended, as the historical facts before that period are rather doubtful. Since that time, however, during the whole of that and the following century, the progress in the labour, and of the results of it, have been regularly increasing. The mines of Tasco, Zultepec, Pachuca, and Tlapujahua, whose workings had commenced at the earliest period of the Spanish dominion, had languished in a state of comparative inactivity, but in the period from 1620 to the end of that century had gone on regularly increasing, and the same was the case with those mines which are within the district of Zaccatecas. 
In a country like Mexico, where the population, though much extended, was numerous, as the capital to set labour in a state of active operation was augmented, it was natural that the chief object to which that labour was applied should become more and more productive.

Mexico, in the age under consideration, yielded gold as well as silver. It was found sometimes alone, but more coinmonly in the silver and other ores, and when so found was separated by a subsequent process. Without entering more minutely into a subject where all the ancient documents are obscure, we may safely conclude with Humboldt that the whole of the precious metals produced in Mexico had so increased between 1600 and 1700 , that, in the last ten years of the century, the mines delivered to the mints, in gold and silver, to the amount of more than five millions of piastres. Upon a review of what is recorded of Peru, Columbia, Chili, and Buenos Ayres, as it has since been called, we conclude that the quantity supplied by them in the same century was somewhat larger. Taking these together, we average them at ten million five hundred thousand dollars or piastres. Besides what was supplied to the mints, and paid the duty to the crown, the same accurate writer calculates that one-fifth part of both metals was conveyed away by contraband means-a calculation by no means unreasonable when the high duty is considered, 
and looking at the extensive frontier which was to be guarded. This would make the supply amount to twelve million six hundred thousand piastres.

Brasil at that time had begun to collect gold, though not to the extent which it reached in the following century; it may, however, be safely estimated, even then, at one million dollars. 'To the supplies from America may be added what little the mines of Europe and the rivers of Africa contributed to the general stock, which appears to have amounted to about one million four or five hundred thousand dollars. Thus the sum of fifteen million dollars annually, or taking the dollars at four shillings and two-pence sterling, three million three hundred and seventy-five thousand pounds, would nearly agree with the estimate which Humboldt has assumed.

This would give an increase to the precious metals in the whole century of three hundred and thirty-seven million five hundred thousand pounds. In the eighteenth chapter of this inquiry (page 70) the conclusion has been arrived at that the stock in Europe applied to the purposes of money might amount to about one hundred and thirty millions sterling. If the same allowance be made for wear in the hundred years as has been before presumed, that coin which was in circulation at the end of the year 1599 would in the year 1699 be reduced to eighty-seven million pounds.

In the former period it has been estimated that 
the silver and gold which was transferred from America to India through Europe amounted annually to one-tenth of the supply furnished by the western continent. Although the Dutch, the English, and the French had shared with the Portuguese in the trade to India, and had enlarged it very considerably, yet there is no reason to conclude that the demand for silver and gold for the trade with Asia had proceeded through the whole of the century at a rate which would make it necessary to send to the east a larger proportion of the whole produce than in the preceding century. If then, as before, the supply for the east be taken as one-tenth, the additional quantity to be applied to Europe would be three hundred and four million seven hundred and fifty thousand pounds.

It is difficult to fix what proportion of this amount would be applied to other purposes than that of money. It is natural to conclude that with the low price of any commodity the consumption of it will increase. This is the same with the precious metals as with every other commodity, though some confusion of ideas arises from viewing them most commonly in their other character, that of a measure of the value of all other commodities. An ounce of silver may be considered as worth at all times five shillings or six francs, and therefore an alteration in its value is marked in a different manner from that of other 
commodities, which are never measured by themselves. But if silver or gold be measured by corn, meat, cloth, or other articles, those who want such articles can procure a larger quantity of them for the same weight of those metals. The holder of silver has thus a larger surplus of his peculiar goods, which may be, and a part probably will be, destined to be converted into goods of silver, as well as applied to other luxurious indulgences.

As the conversion of money into plate depends much on the low prices of the precious metals, so it is forwarded by peace and prosperity, and generally retrogrades in seasons of war or turbulence. The beginning of the century was a season of more than usual tranquillity. In England, till the civil wars under Charles the first began, there was external and internal peace. In France, till the year 1620, there was no foreign war; and the internal war concerning religion, though furious whilst it continued, lasted, with peaceful intervals between, not more than eight years. Spain, though not reconciled to the loss of the Netherlands, ceased to carry on war there, and was only disturbed for a few years by the Portuguese having separated themselves from that kingdom. The prosperity of Holland was rapidly approaching to its greatest height. Germany was subject to that tremendous scourge the thirty years' war on account of religion, in which the 
heroism of Gustavus Adolphus of Sweden was displayed, to the tremendous annoyance of the country whose liberties he secured. Italy, though the commerce of its trading cities was lost, was at least tranquil. The beginning and the end of the century were far from a state of insecurity; and it seems natural to conclude that if a great part of the gold and silver which was collected and had been appropriated to luxury in the first forty years had been, during the middle of the century, converted into coin, much of it would return again to commodities in the succeeding years of tranquillity.

'The decorations of the catholic churches and monasteries were still increasing. The dresses of civil and military men were decorated with a profusion of gold and silver lace and embroidery. The residences of kings, princes, nobles, magistrates, and rich citizens were furnished with looking-glasses and pictures in silver frames; and even tables are still to be seen in many houses of that age, if not of massy silver, yet cased with a covering of that metal. The precious metals did not then indeed descend to ranks so low as those which now use them; but even the traders, clergy, lawyers, and others of the middle ranks began to collect a few spoons of silver, and a few other articles of domestic furniture of that metal. Gold rings were very much increased, and ear-rings, as well as necklaces, of the same metal, were a common ornament with all of the middle and many 
even of the labouring and mechanical classes of females. Few of the women would enter into the married state till the joint savings of herself and her lover had amounted to sufficient to purchase a wedding-ring of gold. In this age the manufacture of watches of silver and gold became much simplified and improved, and the use of them vastly extended. As long as the making them remained in the hands of a few ingenious and skilful persons who were rather artists than artisans, the price was high, and the numbers worn were comparatively few; but as fast as the value of the cases in which the machinery was enclosed declined, and as the forming the interior parts was divided among different descriptions of workmen, so fast did the demand increase, and a watch became the common appendage to the dress of every man and most women in the augmented number of persons in the middle ranks of society.

The use of an article among a few hundred, or, when comprehending all Europe, of a few thousand rich or noble families, may be considerable; but when it extends to the millions, however small the portion of each may be, the whole mass collected will be increased to an incalculable extent.

If we suppose Europe at that period to have contained one hundred million inhabitants, and one-tenth of these to have been married or widowed females, with each a gold ring of only a pennyweight of gold, the value of them would amount to two million pounds sterling. If we 
suppose that one-tenth of the inhabitants had a silver watch, and one-hundredth part a gold watch, with cases weighing two ounces, the whole would amount to near twenty millions sterling. The supposition is made without any assumption of its correctness, and merely to show the prodigious extent and consequent consumption of an article when from the decline in its value it descends to the most numerous classes of society.

In the preceding century, the silver or the gold which formed the hilts of the knights' swords, or the spurs fixed on their heels to denote their rank or their valour, the embroidery on the cloaks of the magistrates, the jewels on the habiliments of kings, nobles, and high-born dames, might give splendour to the tournaments and attract the notice of the chronicler or historian; but the value of such decorations would amount but to a most insignificant trifle when compared with the whole of those smaller portions of gold and silver possessed by the many millions in the ranks below them, who in the century that followed began to assume their just station in society.

Under consideration of all the changes in the circumstances of European society, it seems fair to conclude that the proportion of the precious metals in the seventeenth century which was applied to other purposes than making money had much increased beyond that proportion which it bore in the sixteenth century, and which has been estimated in this inquiry as one-tenth. It 
seems, therefore, probable, that instead of onetenth only being diverted from its application as coin to that of ornaments and furniture, an assumption may be admitted that it at least amounted to one-fifth.

In that view of the subject gold and silver would have been added to the coined money to the amount of two hundred and forty-four million pounds. But allowance must be made on this sum for the regular wear, at the rate before estimated, of one part in three hundred and sixty annually, which would amount to about thirtyfour million pounds; thus leaving, at the end of 1699 , coin in circulation in addition to what existed at the end of 1599 , as may thus for greater clearness be exposed in figures.

Stock of coin left at the end of 1599

Deducted from this by abrasion and loss in the $\mathfrak{E} 130,000,000$ course of a century, to the end of 1699

$43,000,000$

Produce of the mines in 100 years $337,500,000$

$87,000,000$

Transferred to India and China in part by the Philippine Islands

Deduct a fifth converted to other $33,250,000$

$304,250,000$ objects than that of coin $60,250,000$ $244,000,000$

Deduct from this by wear and loss $\mathbf{3 4 , 0 0 0 , 0 0 0}$

$210,000,000$

$£ 297,000,000$

By this account, taking the stock of coined 
money at the end of 1599 at one hundred and thirty million pounds, and of that stock at the end of 1699 at two hundred and ninety-seven million pounds, we find an increase in the hundred years at the rate of about one hundred and fifty per cent., or double and a half.

The doubts respecting the prices of corn have been before fully stated, but at the two periods whose comparison it is now necessary to make, though still subject to doubt, there are more accurate records than in the preceding series of years, when for want of better criteria recourse has been reluctantly had to them.

The prices of corn here referred to are those of Oxford, taken from the valuable publication of Mr. Lloyd ${ }^{1}$; and to avoid the influence of variation on the productiveness of the series of years, a greater number of years is comprehended in the estimation. In the twenty years from 1483 to 1502 , both included, the average price of wheat was twentyseven shillings the Winchester quarter; in the twenty years from 1583 to 1602 the price was thirty-six shillings per quarter, or an advance of thirty-three per cent. Malt ${ }^{2}$ in the first period was sixteen shillings and a penny, in the last period twenty-two shillings and a penny, which shows an advance of thirty-eight per cent. This

${ }^{1}$ See Appendix, No. IV., in Lloyd, p. 325.

$\&$ In the prices of malt noallowance is made in this calculation for the duty of four shillings per quarter first imposed in 1697 , and for the subsequent alterations in the rate of duty. 
view of the rise, taken from accurate tables, does not appear to correspond with that which the acts of the legislature would lead us to infer. As had been before noticed in 1593, the price of wheat at twenty shillings the quarter was deemed sufficiently low to warrant permission to export it ; but in 1688 exportation was not allowed when wheat was above forty-eight shillings. If these enactments may be taken as the proportion of price between 1593 and 1688, the advance would be nearer to the increased quantity of the money in circulation than is shown by the Oxford tables of Mr. Lloyd.

It is, however, scarcely possible that the increase of prices should keep an even pace with the rate of augmentation of the precious metals. It may be so in the early increase of money, but could not long continue. The additional quantity of money, acting as a stimulus to industry, would increase the mass of commodities to be exchanged, and thus a greater portion of money would be needed to circulate them. This may be familiarized by an hypothetical case. Let it be supposed that the whole mass of commodities is reduced to two articles, corn and cloth, in equal quantities, as one hundred thousand quarters of corn and one hundred thousand pieces of cloththat the cost of production of each quarter of corn and each piece of cloth is the same. The value of them in exchange would then be equal. We 
must suppose the value of them to be a pound weight of silver, or sixty-two shillings. If the same quantity of silver remained, and the corn was increased to two hundred thousand quarters and the cloth to the same number of pieces, their exchangeable value with each other, the demand continuing in equal proportion, would be the same as before. But when exchanged for silver they would obtain a less quantity of that metal. In common language they would fall in price. If the silver were doubled in quantity, the cloth and the corn, with the same value to each other, would be the same with respect to silver, and the price would be said to be stationary. If one-half the silver was annihilated, the cloth and the corn would both be equally affected by it, and, without changing their position relative to each other, would become of less value in exchange for silver, or would be said to have fallen in price. Though this mode of stating a case may serve to illustrate the effect of the rise or fall of prices, yet it cannot be made applicable universally.

Whilst from the years 1600 to 1700 the augmentation of the stock of gold and silver was in progress, the general stock of commodities in like manner, but at what proportional pace it is difficult to determine, was also advancing. The gold and silver in a country, contrary to the opinions of the vulgar, are the least part of its wealth. They can scarcely, under any of the changes of metallic 
value which they may cause in other commodities, amount to a hundredth part of the wealth of a country, and in a prosperous state they will bear a much less proportion. The possession of them is real wealth only in a small degree, though every addition to them produces real wealth by the stimulus which the apparent advance of prices gives to every kind of industrious exertion.

It is impossible to collect any accurate ideas of the proportionate increase of commodities in general. An approximation only to accuracy can be expected, and that with faint hopes of success.

Between the reign of Elizabeth, which terminated near the end of the sixteenth century, and that of William, which ended nearly one hundred years later, there had been an increase in population in England as well as in the other countries of Europe. The inhabitants of England and Wales are calculated by Mr. Rickman to have been in the year 1700 about five million four hundred and seventy-five thousand, and to have increased in the course of the following century at the rate of seventy per cent. As we have found, by the two censuses taken since that of 1801 , that our population has increased at a greater rate than in the last century, so it seems natural to calculate that it had increased more rapidly in the seventeenth than in the sixteenth. We therefore assume a lower rate, and, estimating the population in the year 1500 at three million eight hundred thou. 
sand, calculate that it had increased at the rate of fifty per cent. in 1600, which is near enough to the estimation of Mr. Rickman for the purpose to which it is here applied.

As far as a slight but not thoughtless examination can be depended on, it appears that the other portions of Europe must during the same period have experienced a similar but probably not an equal augmentation. It is fair to suppose that France had kept nearly an equal pace with England. Spain, if she had increased her inhabitants, must have done so, from the expulsion of the Moors and Jews, and from the emigrations to America, at a much slower rate. Germany could scarcely have more than recovered in the last fifty years of the century the desolation and depopulation occasioned by the thirty years' war, which occupied the greater part of the first half of that century. Hungary, Poland, Prussia, and Switzerland had certainly increased, and probably nearly at a rate approaching that of England; whilst Italy, Holland, and the Netherlands had proceeded with a pace equal to our own. The northern kingdoms of Denmark and Sweden, and the eastern empire of Russia, had in some measure, but to what extent must be doubtful, probably also been getting more densely peopled.

On the whole we venture to assume, that in the period of one hundred years from 1600 to 1700 the mass of inhabitants in Europe had received an. 
addition to their numbers of at least forty on the hundred. Now the bare subsistence of this increased population, even in exactly the same manner as their ancestors had lived, would require an augmentation in the commodities which were the subject of exchange commensurate with the increase of their numbers, and to circulate such commodities, an addition of money at the rate of forty per cent.

But mankind in Europe did not continue to live as their ancestors had done. In the course of the century the production of necessaries, of comforts, and of luxuries had proceeded with more speed than the progress of population. The prohibition which existed in the time of Elizabeth, against converting arable land into pasture, had become obsolete in England. More cattle were reared and fattened, and by the manure they supplied to the soil more corn was produced on the same portion of land with less labour, and thus labourers were gradually furnished for other branches of industry. The author of Fleta, who wrote in the reign of Edward I., says, "that if land yielded only three times the seed sown, the farmer would be a loser unless corn should sell dear." Sir John Cullum, in an account given of a farm in Norfolk, states the produce in the year 1390 to have been wheat six bushels, barley twelve bushels, and oats only five bushels : that year was indeed an unproductive one, and he rates the average annual pro- 
duce of all corn to be twelve bushels to the acre. In the century which we are viewing, at an early part of it, the annual produce had increased, according to Harrison in his "Description of Britain," at least one-third. It was not, however, wholly on corn and cattle that an increase of production had taken place, but new articles had been introduced which became sources of real wealth. The common cabbage was scarcely cultivated till the beginning of the seventeenth century. Artichokes, currants, cherries, onions, asparagus, and, above all, potatoes, were introduced in the early part of the century. Turnips, carrots, parsnips, early pease, rape, and the several kinds of clover were only adopted in the middle of the century, and were not very generally cultivated, or not nearly to the present extent, at the latter end of it. The increase of articles which these advances in cultivation brought into the general market required more money to circulate them than was needed for the more common productions of the soil which had. previously been used. Corn, when grown upon the small spots of land which farmers occupied in ancient times, was chiefly consumed on the places where it grew and by the labourers that raised it; but these new products would be carried to other - places to find consumers; they must be paid for not with labour or with other agricultural productions, but with money.

There must also have been a larger stock of 
corn generally in store, either in the stacks or the barns of the cultivators, or in the hands of dealers and millers. This may be inferred from the less variation in the price of corn in the century in question, when compared with the excessive fluctuations which are recorded of the preceding ages. In the whole hundred years from 1600 to 1700 , the lowest price of wheat on the average of the year was $19 s .10 d$. per quarter, and the highest price $3 l$. 2s. $9 d$. ; whereas in former ages the variations in its price, within the compass of a few years, was from $8 s$. to $6 l$, and in one instance from $8 s$. to the enormous price of $19 \mathrm{l}$. 4s. The greatest variation in any one year in the seventeenth century was in 1662, when before harvest the price was $4 l$. and after harvest, $2 l .5 s$.; but in the preceding century, in the year $155 \%$, wheat which before harvest was at $2 l .13 s .4 d$. fell after that to $5 s$.

From this contrast of fluctuations two inferences may be drawn : first that there had been a great improvement in the practice of cultivation, for good husbandry has a tendency to counteract the vicissitudes of seasons; and secondly that there must have been a stock at the end of each productive year, which could be retained by capitalists, and would diminish the weight with which a year of scarcity would otherwise fall on the community.

Not only the surface but the bowels of the earth contributed to the production of additional com- 
modities. The product of the woodlands which had before supplied, the chief part of the fuel, near the districts in which it grew was consumed in the form of wood, and at a distance from those districts, and in the large towns and manufactories, in the form of charcoal. As the woods became exhausted, and the soil devoted to arable or pasturing purposes, the repugnance to fossil coal was gradually removed, and the mines of that substance yielded a commodity of great amount, and that amount increased according to the distance from the places of consumption. The metallic mines also had been worked more extensively, and iron, copper, lead, and tin had been converted into tools, implements, and domestic utensils, not only sufficient for the internal use, but supplying a surplus which formed a branch of the foreign export trade. The more ancient manufactures of woollen and worsted goods and much linen cloth were woven, though a great portion of the flax was obtained from Flanders, and much of the yarn was spun by the peasants of Germany. As the food, fuel, and clothing of the inhabitants, and their implements, had been increased, so also their residences and the furniture had increased in real amount. When Erasmus visited England in the former century, the houses were built of mud and wood, were thatched with straw, and instead of floors the bare earth was covered with rushes or straw; but in the latter end of the seventeenth century, the dwellings in 
towns were chiefly constructed of stone or bricks, were covered with slate or tiles, and floored with timber.

The fine arts had made considerable progress in the preceding century, as well as in that under review, and the statues, but especially the paintings, had acquired a great value. The great masters of Italy, of Flanders, of Spain, of Holland, and even of England and France, had produced works which were high in price, and which may be added to the list of general commodities, and like the others would require the use of money to exchange and distribute them.

The trade which had been created in the preceding century by opening an intercourse with India by sea, and by the discovery of America, had changed the small and ill-equipped vessels fitted only to perform coasting-voyages for large, wellbuilt, and costly ships, appropriately constructed for the long and perilous passage beyond the Cape of Good Hope, to the eastern shores of America, and in some cases to the more remote parts of that

- continent beyond Cape Horn.

It would perhaps be presumption to attempt to estimate the amount of increase in the mass of commodities during this hundred years; but if the number of inhabitants in England had been increased from three million eight hundred thousand to five million five hundred thousand, and if in this latter number each class had increased 
their wealth-not as measured by money, but in corn; in cattle; in the improved condition of the soil ; in the number, condition, and furniture of their houses; in their implements of industry and domestic utensils; in their fuel and clothing; in the stocks of goods in stack-yards, barns, shops, and warehouses; in their carriages for business or pleasure; in their ships and boats; and, in short, in all the various descriptions of real wealthwe may fairly conclude that the five million five hundred thousand individuals in 1700 enjoyed at least double the amount of material wealth that was possessed by the three million eight hundred thousand in 1600 . If that conclusion be admitted, it must follow, that as the new commodities would for the most part not be consumed by those who produced them, but must have been exchanged for money, more than double the quantity of silver and gold in the form of coin must have been required for easy circulation, and to keep their money prices from falling.

This view has been more minutely directed to England than can be necessary with respect to the other European commonwealths. Some few of those countries advanced both in wealth and population at a more rapid pace than England. It was the case with Holland; with the Netherlands, then comprehending the part now known as French Flanders; with the plains of Lombardy; and perhaps with that which now makes a part of 
France, but then Germany, distinguished as Alsace. France probably increased at a pace equal to England till the latter end of the century, when the boasted glory of Louis XIV. terminated in the sufferings, and depression of his dominions. Spain and Portugal did not probably improve so fast as those countries to which the treasures of America passed through them. The eastern and northern kingdoms preserved in general a sluggish pace, though they also advanced in substantial wealth, and probably reached a height as great, in proportion to the station from whence they started, as the more civilized and more cultivated people to the westward and southward of them.

From the intercourse which existed through the greater portion of the period between the several states of Europe, the precious metals could easily pass from one to the other. The mistaken policy of the several governments induced them to make laws prohibiting their conveyance from their dominions ; but such laws, though they might embarrass the transfer, could not prevent it, in commodities so compendious in proportion to their value as gold and silver.

They, like all other commodities, would go where their value was highest; and thus there would be a tendency in them constantly to produce an equilibrium between their own quantities and the quan- 
tities of the mass of all the other commodities which are exchanged through them.

The value of money will depend on the ideas and habits of the possessor, and in saying it will go where its value is highest no more is meant than that the owner of it will use it in that way which he thinks will produce him the highest gratification. 


\section{CHAPTER XXII.}

On the production of gold and silver from the year 1700 to 1809 inclusive.

$I_{T}$ is not the design of this inquiry to enter into a description of the mechanical inventions by which the ores were obtained from the bowels of the earth, nor the various chemical operations by which the precious metals were separated from the less valuable substances with which they are commonly combined; nor is it intended to enter into the relations of the different classes of society in the countries where those metals were produced, farther than may appear to be necessary to account for the fluctuations in the quantities which at various periods they have furnished to the general commerce of the world.

Mexico as long as it continued under the go- Mexico. vernment of Spain yielded a vast mass of gold and silver. It had from the commencement of the European power in that country increased gradually and regularly, with very few interruptions. We have no intention of entering into the history of the conquest and the continued submission of the native inhabitants. When Mexico was first visited by the Spaniards, some progress 
towards civilization had been made. The country was divided into regular provinces, was subject to one chief who ruled them by his deputies, and who by an hereditary right seemed to have exercised the offices of magistrates and priests. Whatever rude institutions existed were under their protection, and they were the sole possessors of that kind of knowledge which, slight as it may be, was sufficient to keep the great body of the people in tranquil submission to the power that was exercised.

When the Spaniards invaded the country, the opposition that was offered originated with these privileged classes, and they were the chief victims of the conquest. The royal, the noble, and the priestly families were almost wholly destroyed, either by the contests, or by the victors after all regular opposition had ceased. The mass of the people, though they had been thinned in their numbers by war and famine, still remained without any such diminution as could make a scarcity of labourers. Though there was abundance of labourers, there was a want of inducements to labour. The soil supplied with little exertion the slight and inferior food they needed. Their clothing and their residences were of a description suitable to a climate where the severity of seasons is unknown. Their knowledge of the arts of life and their skill in the exercise of them had reached only the very lowest steps of improvement, and those who had conducted them to that step were 
either cut off or removed from any more influence over them.

The natives were scattered tribes speaking different dialects, at spots very distant from and little known to each other, and their characters, names, and circumstances were alike unknown among the rude warriors who had obtained authority over them.

The regulations dictated by the distant European government whose authority the adventurers acknowledged, but whose orders they evaded or disobeyed, were of a paternal character. They were formed upon the idea that these untutored Indians were in a state of pupilage-to be guarded, preserved, and taught like children, but without making any provision for a different treatment when they should arrive at a more mature condition. Amongst these tribes there thus grew up, or perhaps was only continued, a tendency to clanship, in the progress of which a chief, either from some hereditary claims or from a selection amongst themselves, was in authority over each tribe, and exercised the authority with that degree of firmness or of rigour which has been generally remarked in the rulers' of uncultivated people.

This nomination of chiefs to each tribe was, however, favourable to the views of the viceroys, who were appointed by Spain, and to the exercise of power by the subordinate governors of the several provinces. It was desirable to raise some 
money to defray the expenses of government. The taxes paid on all goods by the more populous districts and in the cities where the Spaniards had formed settlements could not have been collected from the Indians, or would have cost more in the collection than their amount. Instead of imposing others, a capitation tax was levied on the Indians, for which each chief was made answerable according to the numbers of which the tribe consisted; and though it was but a trifle from each individual, it was made an instrument of oppression by the chiefs towards those of the several persons who composed the tribe. The Indians were prohibited from buying or selling without the intervention of their chief, who treated all of them as though they were in a state of nonage, directing their labours, superintending their domestic concerns, and punishing them as children are punished when disobeying their parents.

In the early progress of mining the chiefs were able to send a part of their tribe to labour in the subterranean works; and the wages of their labour was received by the cacique, and by him distributed among those employed after reserving a share to his own use.

The change of this condition of society began early and continued gradually. The Spanish adventurers brought with them few females, they naturally formed unions with native women, and a new race increasing in numbers in every genera- 
tion sprung up, who were freed from the trammels of childhood in which their maternal ancestors had been bound, but were by no means placed on an equality with that of their male progenitors and others of the unmixed white race.

As new classes arose, the labours of the mines were increased, but there was a want of capital long felt which prevented a rapid progress. It was necessary in mining to pay for labour before its produce could yield any returns. The purchase of implements, especially of iron pointed with steel, which were to be brought from Europe, required a large outlay; and it was necessary, as far as the practice of amalgamation extended, to provide quicksilver, which, coming also from a great distance, was an expensive commodity.

Mexico was then in circumstances highly favourable to the growth of capital. She enjoyed internal tranquillity; there were no popular tumults of the Indian inhabitants; the creoles were neither sufficiently numerous nor influential to form a party; and fresh supplies of Europeans were continually pouring in, who, whatever their rank or qualifications might be, when united formed a kind of aristocracy, which, with occasional and slight interruptions, was in general obedient to the supreme authority of Spain. In the wars in which Spain was engaged, especially with England, almost every other part of Spanish America had been invaded either by extensive 
armaments or by predatory bands; but Mexico from its physical position had been subject to no such attacks. It thus presents us with an object scarcely observable in any other part of the globe in any age, of a country which for three centuries had never been exposed to internal or external commotions. As, during the continuance of this long period, there was no fear for the security of capital invested in mines, or for that employed in agricultural improvements, however slow the progress, or however impeded by the colonial restrictions and the arbitrary power in the hands of the viceroys, there must have been an increase in material wealth correspondent to that which the produce of the mines exhibits.

Whether the increase be owing to other and to what causes, and to what extent, may be interesting to inquire; but the simple fact that the soil had neither been polluted by the blood of its inhabitants nor by that of invaders, that no hostile foot had trod its surface or attempted to land on its shores for three hundred years, is sufficient alone to account for the progress which Mexico had made up to the time of her fatal revolution.

In the course of three centuries, though the great mass of the aborigines had remained with but little change in their circumstances, yet many individuals of the tribes, especially of those who resided near the cities, had emancipated themselves from the low condition of their race, and 
by agriculture, by manufactures, or by commerce had become possessed of property; and though not received into the ranks of the Europeans, became of great assistance in the creation of wealth and the accumulation of capital.

Though the capital of the country was thus increased chiefly by the labour of the original race of people and of the races which had arisen by a mixture of them with the new settlers, they were not the great adventurers in mining-undertakings. There was little spirit of enterprise among those classes, but what industry they exercised was accompanied with that rigid parsimony which is the sure but slow operating cause of the creation of individual and national wealth. But when capital is created it naturally seeks employment, and the more cautious acquirers or their successors must furnish means to more adventurous spirits to employ that capital in such ways as talent, enterprise, and perseverance can alone direct to successful terminations.

The extent of Mexico, the difference between its progress and that of the other portions of the American continent, but especially the vast quantity of the precious metals which it has furnished, have made a slight view of the origin of its wealth a proper preface to that which we proceed to consider - the actual produce of the mines of gold and silver.

The amount has been already examined into up 
to the end of the year 1699. From that period the progress during the first twenty or thirty years, though constant, was comparatively slow, but towards the latter end of the century became much more rapid.

The great mine of Valenciana, which, during forty years, yielded to its proprietors a clear profit of from eighty-five thousand to one hundred and twenty-five thousand pounds sterling yearly, had been neglected till the year 1760 , and after ten years' labour and expenditure, when the rich part of the vein had been reached, continued for upwards of forty years to yield more than half a million sterling in gold and silver. The rich district of Guanaxuato, which in the years before 1766 yielded only three hundred and eighty thousand ounces of silver yearly, produced in the latter years of its prosperity more than one million five hundred thousand. The mineral repository of Catorce was only discovered in the year 1773 , but it yielded a very large quantity both of gold and silver till 1798, when the value of the minerals declined. The vein of Biscaina, though it began to be worked at the beginning of the sixteenth century, did not become enormously productive till 1762, though in twelve years from that period the owner of it had gained a profit of more than a million sterling, with part of which he presented to the King of Spain two ships of war, one of them of one hundred and twenty guns, and, besides, 
lent him upwards of two hundred thousand pounds, which was never after repaid. The mines of the district of Zaccatecas were about the year 1750 in such a state of abandonment that they scarcely furnished silver to the amount of more than one hundred thousand pounds; but by the spirited exertions of an individual, Laborde, in a few years after their produce was raised to ten times that amount. Thus, whilst the numerous small mining-establishments, if they had not languished, had increased but slowly, the larger ones here noticed, with some others, had made a most astonishing progress.

The gradual increase of capital which had produced this effect had been aided by another favourable circumstance. The supply of mercury had become more regular, and at a cheaper rate. In the year 1590 the price was one hundred and eighty-seven piastres the quintal; in sixty years after it had fallen to eighty-two, in thirty years more to sixty-two, and in the next ten years to forty-two. Mercury had been furnished by the government at a monopoly price: it had been used as an implement of favouritism by the viceroys in Mexico, and the officers under them in the mining-districts. It had been chiefly drawn from Huancavelica in Peru, or from Almaden in Andalusia; but after the calamities suffered by those mines the court of Spain drew a large supply from the Austrian mines of Idria, by which, after gain- 
ing a profit of near twenty-five per cent., it was enabled to reduce the price to the miners in Mexico ${ }^{1}$.

The following is the statement of the produce of the mines of Mexico in gold and in silver delivered to be coined at the several mints, in periods of ten years, reduced into sterling money at the rate of four shillings and two-pence the piastre, as extracted from Humboldt and Ward.

\begin{tabular}{|c|c|}
\hline In the ten years from & $\begin{array}{l}1700 \text { to } 1709 \\
1710 \text { to } 1719 \\
1720 \text { to } 1729 \\
1730 \text { to } 1739 \\
1740 \text { to } 1749 \\
1750 \text { to } 1759 \\
1760 \text { to } 1769 \\
1770 \text { to } 1779 \\
1780 \text { to } 1789 \\
1790 \text { to } 1799 \\
1800 \text { to } 1809\end{array}$ \\
\hline
\end{tabular}

$£ 10,777,298$ $13,697,297$ ] $7,131,921$ $18,860,355$ $23,302,633$ $26,197,936$ $23,506,012$ $34,912,858$ $40,318,948$ $48,191,711$ $47,142,814$

$304,039,783$

It is estimated by Humboldt that the gold and silver of Mexico which did not pay the duty to the king was equal to one-fifth of that which did; and considering the circumstances favourable to contraband transactions, there is no reason to suspect any exaggeration.

Taking it at that amount, there may be added $60,807,956$

Thus there appears, during the whole period $£ 364,847,739$ of 110 years, an annual product averaging

${ }^{1}$ Humboldt, from whose work the foregoing observations on the great increase of the product of the mines in the middle of the last century are chiefly extracted, expresses his wishes that the attention of Mexico could be directed to China to obtain a supply of mercury; and he has lived to see the experiment made of obtaining some from thence, and with hopes of greater future success. 
A division of Peru took place in this century, Peru. when its extent was diminished, first, by the separation from it of the province of Quito, which was in 1718 allotted to the kingdom of New Granada, now denominated Columbia; and, secondly, by detaching from it, in the year 1778 , the districts of La Paz, Cochabamba, Potosi, Oruro, Carangas, and some others, which were then added to Buenos Ayres, on occasion of that province being erected into a viceroyalty. In viewing the produce of the precious metals between the years 1700 and 1810 , it will be better to consider them under the new than the old divisions. Peru, Columbia, and Buenos Ayres, when here spoken of, are intended to be distinguished as they existed in the beginning of the present century, and up to the time when the Spanish authority began to be dissolved.

In this diminished extent Peru, though it contains a vast surface ${ }^{1}$, has very few.inhabitants : they do not appear by any authentic census to exceed one million one hundred thousand persons, among whom are reckoned six hundred and eight thousand Indians, two hundred and forty thousand Meestees, and eighty thousand negroes; and it is doubtful if they have increased or diminished since that census was taken in $1803^{2}$.

1 The extent of Peru, as given by Argüelles in his Diccionario de Hacienda, is three hundred and sixty thousand square miles, or about seven times that of England.

2 The census here mentioned is in the work entitled Guia de Peru, por Hippolito Uanane, printed in Lima, 1804. 
Humboldt attributes to this thinness of the population the little progress which Peru has made in the last two centuries; but to that cause may be added a scarcity of capital to apply to mining, and the unfavourable situation in which the principal mines are found. The mines of Huantajaya are, indeed, in a district not peculiarly severe, but they are in a part of the province of Arica which is entirely destitute of water; and the projects which have been long entertained of conveying fresh water to it for the use of the men and cattle, and salt water from the small sea-port of Yquique for the amalgamation-works, have failed from the want of sufficient capital.

The greatest quantity of silver in Peru has been extracted from the mines of Yauriccocho or Lauricocha, better known in Europe by the name of the mines of Pasco. They are in the midst of mountains covered with perpetual snow, and are themselves at a height of thirteen thousand feet above the level of the sea, and consequently in a severe climate and a barren soil. . They are said to contain masses of silver quite equal to the quantity found in the district of Guanaxuato in Mexico, and at no great depth below the surface. But the unhealthiness of the climate, the expense of conveying necessaries to such an elevation, and the water with which the pits are often submerged, have been hitherto impediments to extensive operations. In spite of the obstacles, these mines have, however, annually delivered, during the 
period under consideration, about eight hundred thousand ounces of silver.

Some mines in the province of Truxillo, known by the names of Hualgayac, Gumachuco, and Conchuco, have been worked ever since the year 1792, and have produced from four hundred thousand to eight hundred thousand ounces of silver annually. The ores of the district are said by Humboldt to be richer than those of Potosi, more regular in their product than those of Huantajaya, and more easy to work than those of Yauricocha.

Some gold was found in Peru, in the districts of Pataz and Huailas, on the ridge of the Cordilleras; some on the plains of Curimayo, near the town of Caxamarca; and small quantities in other parts.

As the gold and silver extracted in Peru were ordered to be carried to Lima to be coined, the only calculation of the quantity actually produced must be framed from the returns of the mint in that city. Of those returns no regular series is at present attainable earlier than the year 1754. It has therefore become necessary to assume-relying upon the reports of all writers that no great alteration had taken place between 1700 and 1754-the annual produce for the whole one hundred and ten years between 1700 and 1810 to have been at the same rate as for those years of which we have statistical reports. In the fifty-five years 
from 1754 to 1799 , the gold and silver which paid the duty on its coinage at Lima amounted to two hundred and forty million four hundred and eight thousand and fifty-eight piastres. If we take double that amount for the whole term, in which there can be no material error, it will be four hundred and eighty million eight hundred and sixteen thousand one hundred and sixteen dollars, or one hundred million one hundred and sixty-nine thousand five hundred and twenty-four pounds sterling.

Columbia. That part of the former Spanish dominion in America to which the name of the Republic of Columbia has been given, and which comprehends the former viceroyalty of New Granada and the captain-generalship of Carraccas, has never been productive of much silver; indeed, in the latter periods of the Spanish power, remittances of silver were annually made from Mexico to defray the expenses of the government in Carraccas.

The western part of this territory has from the first yielded a tolerably regular supply of gold. The whole is the produce of stream-works established in the alluvial districts. Gold veins have been found in the mountains of Guamoco and Antioquia, but their working was almost entirely neglected. According to Humboldt, the gold is the produce of three provinces only, of which the insalubrious district of Choco furnishes one-half, and the remainder is supplied in about equal portions by 
the province of Barbacoas and that of Antioquia. It was coined and paid duty at the two mints of Santa Fe de Bogota and Popayan. It was stated in 1801 to average about two million five hundred thousand piastres, and the quantity had not materially increased or diminished for a long period: it may then be permitted to be taken, during the period of one hundred and ten years we are viewing, at that rate, and thus yielding two hundred and seventy-five million dollars, or fifty-seven million three hundred and fortyone thousand six hundred and sixty-six pounds sterling.

Some silver mines were discovered about the year 1790 in the plain of Supia, when the ores were found in the greatest quantity, but the operations were suspended on account of certain lawproceedings. A mine was also opened at Manta in 1791, which had only produced eight thousand seven hundred marcs of silver, in a period during which the expenses had amounted to two hundred and sixteen thousand piastres, when the working was abandoned. These mines of silver, though here noticed, could only have an insignificant effect on the annual produce during the long term from 1700 to 1809.

The province or captain-generalship of Chili chili. produced small quantities of gold, and during the last century still less of silver. Its produce, however, did not vary much, and the chief part 
of the gold was procured by washing. In the latter part of the century Humboldt states the coinage at Santiago, the capital, where the tax was collected, amounted to seven hundred and twenty-one thousand piastres in gold, and one hundred and forty-six thousand in silver. Argüelles makes the amount in the first years of the present century about thirty thousand more of silver and forty thousand more of gold. As, however, some of the earlier years may have been deficient, it will be assumed that in the period of one hundred and ten years from 1700 to 1809 , the annual amount was eight hundred and fifty thousand dollars, being in the whole term ninetythree million five hundred thousand dollars, or nineteen million five hundred and thirty-two thousand one hundred and sixty-six pounds sterling.

Buenos Ayres.

The viceroyalty of Buenos Ayres, which in the view we now take of it included Potosi, La $\mathrm{Paz}$, and the other western parts called the provincias de la Sierra, produced chiefly silver. The mountain of Potosi had declined in produce from an annual delivery of upwards of a million dollars to less than a third of that amount; but as that source had failed others had become more copious, especially La Paz, Carangas, and Oruro. Humboldt states the annual produce at four million two hundred thousand dollars. Agreeing to this estimate, the amount afforded in the one 
hundred and ten years would be four hundred and sixty-two millions, or ninety-six millions two hundred and fifty thousand pounds.

In the preceding century the whole of the Spanish American dominions have been considered as engaged in contraband transactions, to an extent that made it proper to add to the quantity of the gold and silver which paid the legal duty one-fifth for that which was drawn surreptitiously from the mines and smuggled out of the countries. As far as regards Mexico that proportion has been deemed sufficient in the present century; but in the other portions of South America the contraband transactions were much more extensive through the whole of the eighteenth century.

In the early part of that century, after the treaty of Utrecht, a large supply of negroes was conveyed by other nations to the Spanish dominions; and under the Assiento contract, which was first made with the French, and afterwards transferred to the English, it is calculated that more than fifty thousand slaves were conveyed chiefly to Buenos Ayres to be employed in the mines of the western parts of that viceroyalty, and in some degree to Carraccas and Carthagena to cultivate sugar, cocoa, coffee, and the other productions of the tropical climate. The intercourse was not, however, limited to the sale of slaves. Manufactured goods to a stipulated extent 
were permitted. One English ship was allowed annually to dispose of a cargo, and under cover of her tenders are said to have been at hand to supply other goods as fast as the permitted or registered cargo was sold. This kind of commerce continued from the beginning of the century to about the year 1740 , when the popular cry in England involved the country in a war under pretence of Spanish outrages committed on English contraband traders. It was a commerce which offered great inducements to the Spanish settlers to defraud the colonial revenue, and as the temptation was strong; so it was increased by the corrupt conduct of the officers of the revenue and the facilities thereby afforded to the smugglers.

This state of affairs, on what was then known by the name of the Spanish main, continued for near forty years, and though the war of 1740 suspended first, and soon gave a different direction to the trade, it was continued under another. form to the end of the century. Don Juan de Ulloa, in his despatches to the court of Spain, enters into the details of this trade, which shows it to be very extensive, and that large quantities - of silver and gold were surreptitiously exchanged for the goods of England, Holland, China, and India ${ }^{1}$. This commerce was active on both shores

${ }^{1}$ See Noticias Secretas de America, cap. 9. 
of America. The traders from the interior of New Granada, as far as .Popayan and Quito, repaired to Carthagena, Santa Marta, and Rio de la Hacha on the Atlantic for the European goods, and to Panama and Guayaquil for the productions of Asia, the greater part of which were exchanged for silver or gold, of which a large portion had never paid the tax to the revenue.

In the succeeding period an intercourse between the Spanish main was constantly kept open with the Dutch Islands of Curaçoa and St. Eustatia, with Jamaica, and with the Danish island of St. Thomas. Great quantities of silver and gold were conveyed to those settlements in a form that proved clearly their having never paid the duty.

In the latter part of the century, during the war, there was a very active trade with the Spanish colonists along the whole coast of South America. English and American vessels, under the pretext of supplying negroes, conveyed large cargoes of British manufactures to Buenos Ayres. Vessels under both those flags, engaged in the southern whale fishery, took incidental opportunities of selling those goods which from the state of war could not be either conveniently or advantageously supplied from Spain, although they were most urgently required. Besides these, many English vesisels, so strongly armed as to defy the Guarda Costas, frequented the shores of Chili and Peru, and carried on what was profes- 
sionally called "the force trade." At Moro Morena, Yqueque, and other landing places where there were only slight or no garrisons, such ships anchored, and trains of mules were seen crossing the mountains with silver, as it came from the amalgamation moulds, with ornaments and utensils, with images of the virgin and other holy persons, with crucifixes in great abundance, and with the spurs, bits of the bridles and saddle furniture, all eager to exchange them for the scarce manufactured articles of cotton, linen, and wool, with which the markets of England were fully stocked if not overloaded.

On a review of this commerce, and taking into consideration the compendious nature of the precious metals, and the great effects which by the accounts of all reports from Spanish America might be produced by bribery of the officers of the revenue, we are reluctantly compelled to differ from Baron Humboldt in the estimate of the proportion between those metals which did, and those which did not pay the duty between the years 1700 and 1800 , especially as we include, under the same head, some of that which passed from America to Asia by the Philippine Islands. The estimate of one-fourth, instead of the Baron's estimate of one-fifth for Columbia, Peru, Chili, and Buenos Ayres, which is here assumed, would be gold and silver which had paid the duty, thus:- 
Peru

Columbia

Chili

Buenos Ayres

Produce paying duty

Produce on contraband
- $£ 100,169,524$ Sterling

$57,341,666$

$19,532,166$

$96,250,000$

$273,293,356$

$68,323,339$

$341,616,695$

Produce of Mexico as before stated $364,847,739$

$£ 706,464,434$

To this estimation of the produce of the gold and silver from Spanish America must be now added the gold furnished by the Portuguese territories in Brazil. Humboldt estimates their annual produce in the year 1800 at four million three hundred and sixty thousand dollars. His calculations do not, from any thing that appears, seem to have been drawn from any statistical accounts, and can be no safe guide. For the first half of the century no notices but those of too loose a nature to deserve confidence have been attainable. In the appendix to the report of the bullion committee of the House of Commons in June 1810, there is an account of the produce of the quintos, or duty of one-fifth from the 1 st of August 1751, to 31st of December 1794, for the two greatest mining provinces of Brazil, those of Minas Geraes, and of Minas Novas; and also of the district of Goiazes. There were other mines in Brazil, in Cuiaba, Jacobina, and Matagroso, 
but their produce was very inconsiderable when compared with that of Minas Geraes. By the accounts it appears ${ }^{1}$ that there was a decrease in the amount of the quintos on gold as thus shown:

\begin{tabular}{|rrrr} 
& \multicolumn{4}{c}{ Arobas. Marcs. Ounces } \\
Annual average from 1752 to 1762 & 104 & 7 & 5 \\
1763 to 1773 & 90 & 3 & 1 \\
1774 to 1784 & 69 & 20 & 4 \\
1785 to 1794 & 45 & 41 & 5
\end{tabular}

The actual produce of these two great mining provinces in the fifty-one years yielded to the crown by a tax of one-fifth the weight, three thousand three hundred and sixty-nine Brazilian arobas of gold. The aroba contains two hundred and twenty-six thousand six hundred and fortyfive English troy grains, and the value of each aroba in sterling is one thousand eight hundred and twenty-one pounds seventeen shillings and four-pence, and consequently the whole sum received in the fifty-one years was six million one hundred and forty-three thousand eight hundred and sixty-seven pounds sterling, which multiplied by five, gives as the amount of the produce thirty million seven hundred and nineteen thousand three hundred and thirty-five pounds. The mines of Goiazes, and those of Cuiaba, Jacobina, and Matagroso being uncertain, may without risk of any great error be taken at nine million two hun-

'See Bullion Report of 1810, Appendix, No. 21. 
dred and eighty-one thousand six hundred and sixty-five pounds, making forty millions in the fifty-one years. We take the other fifty-nine years at the same amount, and add to the gold and silver of Spanish America between 1700 and 1810 eighty millions, thus calculating

Spanish America Portuguese America
\&706,464,434

$80,000,000$

$786,464,434$

$7,146,767$

Or an annual product of

If to this be added the gold and silver of Europe and the gold dust from Africa, taken at

853,233

We conclude that the sum of .

$8,000,000$ was the annual produce of the mines. 


\section{CHAPTER XXIII.}

On the rate of loss on gold and silver coin by abrasion in remote and recent periods.

IT has been hitherto assumed in this work that the loss on the general mass of coined gold and silver by wear alone amounts to a three hundred and sixtieth part yearly. As from the greater increase of those metals more use of them was made for money, so the more general and rapid circulation of them, and consequently a greater loss by abrasion, naturally took place. We are arrived at a period when it appears to be necessary to make an alteration in the rate of the loss occasioned by wear. In showing the grounds of that alteration it may be most convenient to go back and show the grounds on which the former assumption was made.

In examining this subject, reference must be had to the several experiments, the particulars of which are detailed in the Appendix No. 1, to which the reader was referred in the first volume. The experiments made by the officers of the mint in April 180\%, and the 16th December 1826, throw much light on the subject. It is, however, necessary to go a little farther back to a course of 
experiments conducted under the direction of a committee of the privy council ${ }^{1}$ between 1798 and 1802, by those eminent chemists Mr. Cavendish, since deceased, and Charles Hatchett, Esq., who, happily for himself and for all who know him, still survives.

The object of those experiments was not expressly for the purpose of ascertaining the loss on gold by abrasion in a given space of time; but to ascertain what kinds of alloys and what proportion of those several alloys formed the mixture of me- tals which rendered them when coined into money least liable to loss by abrasion. Mechanical contrivances were adopted for rubbing against each other pieces of metal of different proportions and kinds of alloys, and by comparison of their weights before and after such rubbing, to determine which description of them would form the metal least subject to loss for the future coinage of Great Britain.

It was ascertained by the experiments of these accurate and acute philosophers, that gold of the finest quantity that could be used, viz. that consisting of twenty-three parts and three quarters of pure gold, and one quarter alloy, suffered a much greater loss by friction than our standard gold of twenty-two parts in twenty-four of pure gold, and

1 These experiments are recorded in the Philosophical Transactions for the year 1802, part first, page 160. 
two parts of alloy; whether that alloy was of silver alone, or of silver and copper in equal proportions.

Without entering into these numerous experiments, it is important to our purpose to remark that our British standard gold is proved by them to be less susceptible of loss by abrasion than that of any other of the several kingdoms of Europe, or than any that is coined in either Spanish or Portuguese America ${ }^{1}$.

It appears by the same experiments that our standard silver suffers a much greater loss of weight by friction than the standard gold, and is equal to that on gold of twenty-three carats and threequarters fine. It is also made clear that there is a loss by friction on stamped pieces of gold, somewhat greater than on pieces with smooth surfaces.

It is shown by the Appendix No. 1, A, that the loss of weight on three hundred and fifty sovereigns in the year 1826, which had been coined

1 It appears that the loss on gold by the same quantity of friction was with the different alloys as follows, viz.: on our standard gold, if alloyed.with silver alone or with equal parts of copper and silver, $4 \frac{20}{100}$ on 854 grains; if alloyed with tin and copper, $15_{100}^{30}$ on 846 grains ; and if with iron and copper, $21 \frac{60}{100}$ on 825 grains. As the alloy in our new coinage consists chiefly of silver, it is said that a practice has lately been adopted of sending the sovereigns to Paris, where, in consequence of an improved mode of parting the metals by sulphuric acid instead of nitric acid, the silver was taken out, and an equal alloy of copper supplied its place, and then being still standard, the gold in ingots has been returned to England and recoined into sovereigns, which may be distinguished by their deeper colour, but which contain the legal quantity of 22 parts in 24 of pure gold. 
nine years before, viz. in $181 \%$, was at the rate of four shillings and six-pence farthing on each hundred pounds. If then it be taken as five shillings for ten years, it will appear that one part in four hundred only had been lost. It must, however, be considered that the sovereigns though coined had not been issued till the bank restriction was removed in the year 1823 ; that after that period few or none had travelled into the country; that none were seen in Scotland or Ireland; that whatever came into the hands of the country bankers were locked up till a safe opportunity presented itself of returning them to London; and that even in London the circulation of one and two pound bank notes was greater than that of sovereigns. There seems to be a great difference in the loss on a parcel of gold coin in London between that taken in a retail shop and that received from a banking-house. Thus by Appendix, No. 1, B., it is seen that a given number of guineas in the year $180 \%$, collected in a retail shop, was deficient one pound three shillings and fourpence per cent., whilst those received at a banking-house were only deficient eighteen shillings and eleven-pence per cent. As the experiment at the mint was probably made from a number of sovereigns taken from the Bank of England, they were most likely in better preservation than what would have been taken from a banking-house; as the bank at all times has been very strict in receiving no gold coin 
that is not the full legal weight. This was so much the case that when gold rose so that a light guinea as bullion was worth twenty-five or six shillings, the bank refused to take it as money at twenty-one shillings.

It may be farther observed with regard to this experiment of 1826 , that those pieces which had been coined but one year suffered a much greater proportion of loss than those which had been coined five years or nine years. Those of one year old suffered a loss of one shilling and threepence, which in the ten years would be twelve shillings and sixpence, whereas those of nine years appear to have lost only at the rate of four shillings and sixpence. It deserves also to be remarked that the dirt accumulated on the pieces is a better criterion of the length of time they had been in circulation than the loss on weight. If the period of circulation be measured by the portion of dirt adhering to the pieces, the conclusion from this experiment would be that the pieces coined in 1821 had circulated more, if not longer, than those coined in 181\%. The first were found to have three grains of dirt to each hundred pieces, and the second, though double their age, only two grains of dirt to each hundred pieces. The pieces which had been coined but one year were found to have contracted dirt at the rate of more than one grain and a half in that time. If then those of nine years old had equally circulated, they 
ought to have contracted more than thirteen grains of it on the hundred instead of two, as they appear to have done. If judgment be formed from this criterion, the result would be that the pieces coined in 1821 had been issued before those of the prior date, or that they had been despatched to some distant part of the kingdom, and, after passing through a few hands, had at length come back again to the bank from whence they had been issued.

The time when the new coinage was manufactured followed a period of great inactivity at the mint. The officers of that department had. enjoyed leisure and opportunity for exercising those talents for which they are eminently distinguished in investigations and experiments to improve the fabrication of money. Whatever the mechanical or chemical sciences could contribute to that object was examined, and if found appropriate, was adopted. The best alloys were ascertained by which the money should be made most durable, and yet not brittle. The form of the coins was changed so as to render them less subject to loss by abrasion, and other improvements were introduced, which, not falling immediately under the design of this inquiry, need not here be entered into, though they are of great advantage to the public, and reflect high honour on the eminent persons attached to that establishment.

It must, from the observations before made, be 
obvious that the coins issued, with all the improvements which have been so judiciously and so laboriously introduced, can exhibit no fair scale of the loss of gold by abrasion that can be applicable to all ages and to all countries. It would not form an accurate scale for the loss on the coins of England that were issued in the earlier part of the reign of George the third. It would be less appropriate to determine the loss on all the coins issued from the continental mints, either in the old or the new world. It would least of all be fitted to measure the loss on the coins in the time of high antiquity in Egypt, Babylon, and Persepolis, or in the ages which followed, when the Grecian and Roman coins were fabricated, to say nothing of what was transacted in the dark ages.

It is well known by the analysis of ancient coins, as well as by the writings of $\mathrm{Pliny}^{1}$, that, in the times of antiquity, alloys in the gold coin were used of various kinds. Silver was too valuable to be applied to that purpose, and copper was of much higher value than in modern times. Iron and tin were therefore employed to mix with the gold, as thereby the colour of the metal was scarcely perceptibly changed, and with the im-

1 As early as the times of Livius Drusus the silver money of Rome was mixed with one eighth part of alloy of brass and tin, as stated by Pliny in the 33d book, chap. iii., and in the 9th chapter of the same book he says that Anthony, when he was one of the Triumviri, mixed iron with the silver denier. 
perfect knowledge of assaying that then existed the small quantity of those inferior metals could not easily be detected.

It has been shown by the experiments of Messieurs Cavendish and Hatchett that if our English standard gold, consisting of two parts of alloy in twenty-four, were to have that alloy formed of a mixture of iron and tin, the loss by friction would be five times as much as.it is with the kind of alloy applied at the mint ${ }^{1}$; if the alloy were copper and tin it would be nearly four times as much. There is no reason to conclude that the ancients ever used any alloy except tin, iron, and copper, and we may conclude therefore that the loss on their gold coins was from four to five times as great as would be experienced on the modern English gold coins.

The maximum of durability for gold coins seems to be fixed at twenty-two parts in twentyfour of pure gold with the appropriate alloys. When the fineness ascends or descends from that point, the consumption by abrasion is increased. Thus the experiment of Mr. Cavendish and Mr. Hatchett shows, as before stated, that gold of the finest quality that can be worked, viz. of twentythree carats and three quarters fine, suffers a loss of feur times that of the standard of twenty-two fine. On the other hand, the coins below that 
standard wear faster in proportion to their decline in fineness. The twenty franc pieces of France wear faster than even our guineas did. 'Ihe Spanish doubloons are worse than the French gold, and wear away faster; and it is affirmed by some accurate goldsmiths, that the gold used by them of eighteen carats fine suffers a loss very much greater than even the Spanish coin.

Our new gold coinage only commenced in $181 \%$, and the whole amount coined in that year was four million two hundred and seventy-five thousand three hundred and seventy-seven pounds; and in the three next years the coinage amounted only to three million eight hundred and fifteen thousand four hundred and sixty-four pounds, ten shillings ${ }^{1}$. Though partial payments in gold were made at the bank, they were very soon suspended, and it was not till the large coinage of 1821 , when nine million five hundred and twenty thousand seven hundred and fifty-eight pounds had been prepared, that the necessary measure of a general return to cash payments could be with safety adopted. If we may judge from the small diminution of bank notes after June, 1823, when the restriction on the bank ceased, and from current rumours that the bank was overloaded with gold, we should conclude that very little of the new coinage was in circulation before the latter end of 
the year 1825, when the panic in the commercial world created a great drain, and dispersed the larger portion of it. The experiments we are now considering were conducted one year after that panic, and though some of the gold coins upon which they were made may have been coined nine years before, they may not have been in circulation more than a year or two.

It would scarcely be an unfair mode of calculation to presume that the general mass of gold in circulation in December, 1826, when this experiment had been tried, had not circulated more than two years, or two years and a half on the average. If we take the average wear on the three dates of 1817,1821 , and 1825 to have been of three years and a half, eight shillings and tenpence per cent. will be the loss in that time, or about one pound four shillings per cent. in ten years. This would show a loss on that gold coin at the rate of one part in eight hundred yearly.

The report of the experiment of the mint does not seem to be such as can be satisfactorily applied to general circumstances, not from any want of accuracy, but from the peculiar period in which it was made; when the whole of our monetary system was passing through a crisis which rendered it unfit to become a scale for the measurement of the loss which in other times and countries occurs by the wear of gold.

Any scale that can be framed must, however, VUL. II. 
have the coinage of England for its basis; but it may be taken at a different time, when the peculiar circumstances which existed-when, after a long period in which gold was scarcely in use, it became again by degrees into general circulationwere not in operation. In the Appendix, No. 1, $B$, is exhibited some experiments made by the officers of the Mint, in April, 1807, the object of which was to ascertain the deficiency of weight of the average gold coins of the kingdom. At the time the experiments were made, the suspension of cash payments by the Bank had been maintained ten years. There had been, consequently, a suspension also of the wear of the gold, for it had almost all disappeared and could scarcely be said to be in circulation. Between the suspension of the payments in gold at the Bank in 1797 and the date of the experiments in $180 \%$, as very little gold had been coined, that which was in existence must have been of the coinage of years antecedent to 1797 . Before that year all guineas were scrupulously weighed, and what were found deficient were withdrawn from circulation. Thus, in 1797 , a number of guineas taken from a banker's or any other shop could not exhibit a fair average of the wear of the mass of guineas, but only the average of the wear of those which had not been reduced below the current weight. To ascertain the actual average weight of the whole mass it would be necessary to know how many pieces had been with- 
drawn from them from being deficient. 'That, however, could not be known, and it becomes necessary to have recourse to conjecture. It does not seem likely that the guineas to be met with in 1807 were, on the average, of an older date than the year $178 \%$, and the circulation having been suspended for ten years, they could not have suffered more than ten years' abrasion. We see that on one thousand guineas the loss from the standard weight had been eighteen shillings and eleven-pence per cent., or that one part in a thousand and fifty had been lost. We see that on the half-guineas the loss from the standard weight had been two pounds two shillings and seven-pence per cent., or one part in four hundred and sixty. The proportion of the half-guineas to the guineas was, as recently, nearly as one to ten ${ }^{1}$, not on the number of the pieces but on their value. The average wear in the two sizes of coin would then be shown to be at the rate of one part in nine hundred and fifty.

Such appears to be, as nearly as can be known, the loss in English gold coin, which was even at that time the most durable of any in existence. It will have been observed, that the loss on the half-guineas was more than double the proportion to that on the guineas. It is indeed clear,

${ }^{1}$ See Appendix, No. 3, B. 
by all experiments, that the smaller the pieces are, the greater loss do they suffer by abrasion.

The gold coin of the ancients certainly approached nearer to the weight of the half-guineas than to that of the guineas. The aureüs and the bezant were but little heavier than the former, and some of their coins were very much less; and thus the loss from abrasion must have been much greater than on the average of our coin.

It is true that a small portion of the existing gold among the ancients was actually in coin or in that kind of circulation which would cause it to wear excessively; but, on the other hand, if the effect of the alloys they used was, as is shown by the experiments of Messrs. Cavendish and Hatchet, to increase the wear in a fourfold degree, instead of the annual loss being one part in nine hundred and fifty, it would have been at the rate of one part in two hundred and thirty-seven.

Making due allowance, then, for the inferiority of the metal, for the size of the pieces, and for the inferiority of the fabrication on the one hand, and on the other, for the less degree of circulation, it may be assumed that a medium rate of loss was most proper, and that taking it at one part in six hundred would be as near an approximation to the loss of gold by abrasion as is likely to be obtained. It is upon that scale that the general rate of the consumption of the precious metals up to 
the beginning of the eighteenth century has been calculated in this inquiry.

We come now to the other metal, silver, which is of larger amount, and has been so at all periods of the world, and which is subject to much more loss than gold suffers. In examining this part of the subject it becomes necessary to refer again to the Mint experiment in Appendix, No.1, A. It will be remarked by that account that the same difference in loss in proportion to the weight of the pieces occurs in silver as in gold. In this case, it will only be necessary to consider the case of the shilling pieces, which nearly equal in amount the crowns, half-crowns, and sixpences ${ }^{1}$, and may be taken as showing the average loss on the whole ${ }^{2}$; the greater loss on the sixpences balancing the less loss on the larger description of pieces. Though the pieces were coined in 1816 and $181 \%$, the great issue of them did not take place till 1818, and then not more than one-third of them were issued. It appears, then, that the loss in eight years on the shilling pieces had been at the rate of two pounds five shillings and eleven-pence of their value, which would show a loss at the rate of one part in three hundred in each year. This is, however, on the supposition that the whole had been issued at the time, and that the whole had continued in constant circulation; but it is well

${ }^{1}$ See Appendix, No. 3, B.

${ }^{2}$ Appendix, No. 3, A. 
known that more silver was coined than the circulation could absorb, - that much was left in deposit at the Bank which could not be issued,-that the bankers, especially in the country, were full of complaints of the dead weight of the silver coins that were accumulated in their coffers, of which they could make no interest until they incurred the expense of sending it to London, where only it could be exchanged for better money which could be used in discounting or lending out on securities. There was no outlet for it in foreign countries from the high value affixed to it. It was issued at the rate of sixty-six shillings to the pound weight of silver, and as that pound was not worth quite sixty-two shillings in gold, it was considered, and very properly, not as money, but as a token of money, and no one, even in the country where the fictitious value of it was enforced by law, would keep more of it than was necessary in small transactions to make payments of fractions of a pound.

It is neither the design to blame or to applaud the conduct of members of the government which fixed our present silver coinage, and the circumstance does not come under consideration here further than as it may lead to a calculation of what may be deemed the fair rate of its loss by wear.

If we estimate, as we are fully justified in doing, that one-third of the silver coin was in a constant state of rest, either with the Bank of England or 
country bankers, and that two-thirds of those pieces on which the experiment was made had scarcely or at all circulated, we shall come to the conclusion that the wear of the silver coin is about one part in two hundred annually; but this regards English standard silver alone, and not the coins of inferior fineness.

This rate corresponds with that reported in the experiments related in Lord Liverpool's letter to the King ${ }^{1}$. It appears that the officers of the Mint, in 1787, had made an experiment on the silver coins of the kingdom which were then in circulation, and which were much depreciated by wear. The deficiency was ascertained to be at the following extraordinary rates, viz. :-on the crown pieces, $3 \frac{161}{531}$ per cent.; on the half-crown pieces, $9 \frac{991}{1101}$; on the shillings, $24 \frac{196}{3230}$; and on the sixpences, $38 \frac{229}{80} \frac{4}{7}$ per cent. ${ }^{2}$

The same experiment was repeated again eleven years after, in 1798, when the additional deficiency in weight was found to be, on the crowns, $\frac{100}{513}$; on the half-crowns, $1 \frac{33 \frac{3}{36}}{3}$; on the shillings, $5 \frac{55}{3289}$; and on the sixpences, $3 \frac{1189}{8037}$ per cent.

The less increased deficiency on the crowns and half-crowns may be accounted for from the rarity of those pieces, especially of the former, which had become so scarce that whoever got one of them was disposed rather to retain it as a pocket-piece

1 Lord Liverpool's Letter, p. 187. ? Appendix, No. 1, C. 
or curiosity than to put it in circulation. The less additional loss on the sixpences may be accounted for from the circumstance that most of those pieces had by wear become so thin that they would have broken in two when they had lost more than forty per cent. of their standard weight, and instead of being worth, as bullion, their original value of sixpence, were not worth more than threepence halfpenny. The shillings, as being the commonest pieces, are the coins on which the greatest reliance may be placed in any calculation. Their value far exceeded that of all the other pieces, and may therefore be assumed as the fittest scale of depreciation by wear.

The loss on the shillings in this last experiment was at the rate of about five per cent. in ten years, which agrees with what has been before estimated as the loss on the new coinage since 1816 , or about one part in two hundred in each year.

It is to be observed that this wear on the silver coin between 1787 and 179s, was a proof of the degree of loss produced on that particular description of silver coin which was in circulation at that period. Now every one whose recollection carries him back to that time will bear testimony to the fact that the shillings by wear had almost all lost the faintest traces of any impression having been made upon them. No legend was visible, nor could the outlines of the head enable the reign to be determined. They were for the most part 
merely smooth pieces of silver. The wear on them therefore must have been less than on such pieces as, from being more recently stamped, had more raised surfaces.

Practical men to whom the subject of the loss on the metals has been one of much consideration, from being of importance in their several branches of the gold, silver, and jewellery manufactures, commonly calculate a much greater degree of loss on silver than is here shown. One gentleman of great accuracy and acuteness, and much conversant in the application of those metals in his manufactory, communicates his opinion thus. "The loss on coined silver is full one hundredth part or one per cent. per annum. If one hundred pieces of 1815 and 1816 , and upwards to the last date on the silver coin be examined, it will give this result. Though this loss is much greater than on gold, it is easily accounted for ; for first, the same degree of friction will produce a greater diminution of weight, and secondly, the constant and never ceasing circulation of the silver coinage far exceeds that of gold, since it never will be hoarded or kept in a state of rest, it not being a measure of value in this country, but a token or representation of value."

These experiments on silver having been made on coins of the English standard, are not adapted to form a scale by which to measure the effect of abrasion, either on the silver coin of the ancients 
or on that of the modern continental kingdoms, whose silver money was of far inferior fineness. For on silver as on gold coins the rate of loss will increase in the same proportion as the fineness of the silver in the pieces is diminished: and the rate will be farther increased as the size and weight of the pieces, as is the case with the continental coin, is less.

It may now be proper to advert to the grounds on which the rate of loss by friction on the money of ancient times has been assumed to be one part in three hundred and sixty annually. In remote antiquity gold coins were unknown till long after silver coins had been fabricated, and, descending lower, when such coins had been introduced, the amount of the silver very far exceeded that of the gold money. It is impossible to form an accurate or even an approximate estimate of the relative amount of the two kinds of money. It becomes, therefore, necessary for the purposes of calculation to frame a supposititious relation. We assume then that the proportionate amount of the gold money to the silver money was as one to five, or that five times as much silver as of gold circulated. This rate has not been fixed upon without much consideration of the low prices of all commodities which required for their exchange only the lower kind of money; of the product of the mines through the several ages, and of the relative value of gold to silver in the different periods of history. 
If, then, the rate of loss by wear on gold money was at the rate of one part in six hundred, and that money was one sixth of the circulating medium, and if the rate of loss on the silver money was at the rate of one. part in one hundred and fifty, the mean rate of depreciation would be as near to one part in three hundred and sixty as can be calculated. The silver is estimated at one fourth greater degree of friction than our standard silver, because it was at no time equal in fineness to our standards, and in most periods, and sometimes for generations, vastly inferior.

Although the amount of silver in circulation as money at all times must have been greater than that of gold, yet, as the gold has six times the durability of silver, the relative value of the two metals to each other could not be maintained unless the mines produced the two metals in proportion to the loss on them by wear respectively. It seems probable that the due proportion was kept up during the existence of the Roman power, and through the dark ages which succeeded, till the discovery of America, and till the dispersion over the world of the excessive surplus produce of silver above that of gold. The value of gold to silver had varied but little before the mines of Potosi were discovered. Among the Romans gold to silver seldom varied more than from nine to eleven for one, that is, a pound of gold was rarely worth either more than eleven or less than 
nine pounds of silver; nor did the relative value of the metals fluctuate more in the long course of centuries to the time when the new sources of mineral wealth in the western world were in full activity. Since that period the relative value $o$ the two kinds of metal has been gradually changed, and gold is become near fifteen times as valuable as silver, or one pound weight of gold is nearly equal to fifteen pounds of silver. Humboldt has estimated the quantity of gold and silver produced from the whole of America, since the discovery up to the year 1803, to be one hundred and sixty-two million pounds weight of the former, and seven thousand one hundred and seventy-eight million pounds of the latter. The weight of silver to that of gold has been thus about as forty-four to one.

Thus the value of the silver produced since the discovery of America is three times that of gold; but the loss by wear on silver is four times that of gold. In process of time, therefore, it is clear that, from its durability, gold would gain in value upon silver; that is, a pound of gold would become worth more than fifteen pounds of silver. This effect was produced at first in part from the greater proportionate quantity of silver that was procured, and in part by a less quantity of the gold which existed at the time of the discovery of America having been lost by wear than of the silver then in use. In what degree each of these causes tended to preserve the equable proportionate 
value of gold to silver during the two past centuries it would be difficult to determine. But one thing is certain, that as prices rose with the increased quantity of both precious metals, there would be a larger portion of gold used as coin to make large payments, for which silver antecedently was used, and of silver to make those payments for which copper or other inferior metals had sufficed.

From hence it may be concluded that the proportionate value of the gold in the form of coin had changed its relation to that of silver. Both had vastly increased, but gold in rather the greater degree. There was action and re-action. The metallic wealth acted on material wealth by raising the prices of it; and that re-acted on the precious metals by requiring a larger portion of them to effect the necessary exchanges.

Taking into the calculation the superior value of the gold which was used for ornamental purposes on the one hand, and which must have been withdrawn or withheld from its application to coinage, as will be hereafter shown in detail; and adverting to the vastly superior value of the silver which came from America in the form of coined money on the other hand; it seems fair to presume that the proportion of one coin to the other in circulation had been changed towards the end of the seventeenth and beginning of the eighteenth 
century. As far as various considerations unite to enable a judgment to be formed, it may be assumed that the value of the silver money in existence, including the dollars of the American coinages, was as four to one of that of the gold money.

If the wear of the coined money was the same through the time that passed from the year 1700 to 1810 , the loss by friction on both kinds of metal would be at the rate of one part in four hundred and twenty annually. In the remaining calculations the rate of loss will be estimated upon this principle, and it will be extended to the whole mass of coin of Europe and of America.

One reason for making a change in the estimated loss at this particular period is that a general reformation in the state of the coinage was then introduced. In England the evil of a debased coinage was severely felt and loudly complained of during the reign of William III., and it appears that the silver coin which was by far the greatest in nominal amount had from clipping and other causes become so very deficient, that upon weighing a large quantity at the Exchequer in 1695, it was found that which should by tale have weighed two hundred and twenty-one thousand four hundred and eighteen ounces, did in fact weigh no more than one hundred and thirteen thousand seven hundred and seventy-one ounces, thus show- 
ing that the debasement or deficiency was at the rate of forty-eight pounds twelve shillings and fourpence per cent. ${ }^{1}$

It became impossible to proceed farther without a renovation, and though opposed by some powerful factions in both houses of parliament, the measure was resolved on by small majorities, although the country was at the time in the midst of an extended and expensive war.

The restoration of the coin to its due purity and weight in England seems to have produced an improvement in the state of the coin on the continent. In France many changes were introduced, with the express purpose "pour étre en proportion avec les états voisins, et pour empecher qu'ils u'enlevassent l'or et l'argent du royaume."In Germany several of the smaller states formed conventions, by which it was agreed that the money should circulate through the allied dominions upon condition that each sovereign should coin it of the same degree of purity. This was the origin of the best kind of money generally known by the name of Conventions geld. In Italy improvements also took place in the money of most of the states, and on almost the whole of Europe (for the exceptions are few): an increased degree of durability was given to the coins in circulation about the same period.

1 Ruding, vol. ii. p. 387 .

2 Abot de Bazinghen, vol. ii. p. 207. 


\section{CHAPTER XXIV.}

On the consumption of gold and silver and on the rate of prices of commodities from 1700 to 1810 .

In a former chapter the stock of metallic wealth in the form of coin in Europe is estimated at the close of the year 1699, to have amounted to two hundred and ninety-seven million pounds sterling. Upon the principle stated in the preceding chapter, that one part in forty-two of the coin is consumed by friction in the wear of it, in the space of one hundred and ten years between 1700 and 1810, that stock would be reduced at the end of the period very considerably. In the first forty-two years the sum would be reduced to two hundred and sixtyseven million three hundred thousand pounds, in the second forty-two years to two hundred and forty million five hundred and seventy thousand pounds, and in the twenty-six succeeding years to two hundred and twenty-six millions.

In the hundred and ten years under consideration, the produce of the several mines of America and of Europe, with the gold dust from Africa, has been calculated at the rate of eight millions annually, or in the whole period at eight hundred 
and eighty millions. The mode in which this amount has been dispersed and disposed of becomes now the subject of examination. The exportation of the precious metals, chiefly of silver, has in a former period been estimated for India and China at one-fifth of the whole produce which the mines of America had yielded. The trade with India was then in its infancy. It was at first in the hands of the Portuguese, but the Dutch soon became participators in it. The English and French companies had indeed existed, and carried on some trade, but with little success, and to a contracted extent. The union of the two English companies in the beginning of this century gave stability and extension to the commerce, which advanced slowly at first, but towards the latter end of it had increased so as to exceed that of all the other European states together.

The use of tea, which increased and descended gradually from the highest classes in England till it became almost a necessary of life to the very poorest, had caused a demand for silver for the trade of China, which could not have been supplied without that vast addition to the store which the mines of America administered with increasing liberality. This commodity was so extended in this country that its consumption had been in. creased one hundred fold during the century, and even in the thirty years between 1780 and 
1810 had risen from eight to twenty-five millions of pounds weight. The demand for raw silk from China had also rapidly increased towards the end of the term in question, and it more than counterbalanced the deficiency which was created by our improvements in the porcelain and cotton goods, which had in some measure lessened the demand for the nankeens and porcelain of China.

'The trade with India, like that with China, had constantly absorbed a large portion of the silver of Europe. The greater part had passed by sea by the Cape of Good Hope; but there was a current, constant though almost imperceptible, passing from the Levant to India in the south, and from Russia to the north, the latter of which had vastly increased in the latter years of the term.

On the states of North America establishing their independence, they became rivals with the kingdoms of Europe in the trade to India and China, and conveyed to both large quantities of silver. It was especially after the wars which arose from the revolution in France that the intercourse of the Americans with the east had the greatest extension. They were the medium of communication for a long time between France and Holland and their remaining territories in India. The continent of Europe was supplied by their shipping, under the protection of the neutral flag, with tea and the other commodities of China and of India, and conveyed to those distant regions 
scarcely any of their own productions, but chiefly that silver which they obtained from Spanish America and the West Indies in return for flour and other articles the produce of their soil.

This vast demand for the east has been the subject of calculation with several writers. M. Forbonnais supposes that between 1492 and 1724, onehalf of the gold and silver which America had supplied to Europe had been absorbed by the Levant, the India, and the China trade. M. Gerboux, in his work on pecuniary legislation, has not merely advocated the same opinion, buthas computed the proportion of wealth conveyed to the east at a somewhat higher rate. Baron Humboldt, from whose work on Mexico these views of the two French writers are extracted, has taken pains to estimate the proportion of the exports to Asia of the precious metals which Europe had drawn from America. His estimation is made upon an examination of the exports at the time he composed his work, between the years 1803 and 1806, when the amount of gold and silver furnished by America had nearly reached its highest point, when the demand for goods from India had not lessened, and when the exports to India of British productions were far less than at present. His calculation is therefore neither accommodated to the earlier years of the period we are considering, nor is it adapted to measure the proportions which within the few last years have existed. He states the 
silver and gold brought to Europe annually at that time to be forty-three million five hundred thousand piastres, of which he supposes there past to Asia,

By means of the Levant trade $4,000,000$ By the Cape of Good Hope 17,500,000 By the way of Kiacha and Tobolsk $4,000,000$

25,500,000 dollars; or, at the rate we have adopted, $£ 5,318,750$ sterling. This would lead to the opinion that nearly twothirds of the gold and silver furnished by the mines were required and supplied to Asia; which seems improbable, considering the general poverty of its numerous inhabitants, and the small quantity as compared with Europe of the several commodities which furnished subjects of exchange.

We should doubt if in the early parts of the period, when the supplies from America were smaller, the trade of the east could require nearly the same proportion of those supplies as at the period when Humboldt made his calculation. The trade of England at the latter part of the period, when, with the exception of the United States of America, she engrossed the whole commerce of the east, did not require a regular supply of the precious metals to nearly the extent which Humboldt has averaged it at, but much nearer to twofifths than to two-thirds of that quantity. 
With the exception of a short period after the peace of Amiens, the trade of Europe with India and China during twenty-two years, from 1788 to 1810, was almost an exclusive operation of the English; at least the direct trade of the rest of the world by sea did not amount to a third part of the whole. In those years the treasure exported by the East India Company on their own account, as well as on account of the private trade, was fiftyfour million two hundred and twelve thousand eight hundred and seventy-nine ounces of silver coin, chiefly dollars, and five million five hundred and eighteen thousand two hundred and one ounces of silver bullion, with six thousand and five ounces of foreign gold coin ${ }^{1}$. The value of this would, taking the silver at five shillings and the gold at seventy-five shillings per ounce, be nearly fifteen millions sterling, or six hundred and thirty-five thousand nine hundred pounds on the annual average. Now supposing the United States of America, the Danes, Swedes, and Portuguese together exported about half as much-and there is good reason to deem such supposition approaching nearly to truth-we conclude the export of silver and gold in the period referred to to have been at the rate of one million sterling annually. If we allow the accuracy of Humboldt's statements as to the other channels by which gold and silver passed from

${ }^{1}$ See Appendix, No.9, to the Bullion Report of 1810. 
Europe to Asia, we can scarcely calculate the absorption of the latter division of the globe to have been more than two-fifths of the whole quantity produced by America and Europe together. In the absence of that certainty or accuracy which is desirable but not attainable on this subject, we shall assume that two-fifths of the metallic wealth furnished by the mines of America and of Europe during the period between 1700 and 1810 passed from the latter division of the globe into Asia.

We come next to that application of gold and silver by which the ornamental articles of dress, the decorations of public and private buildings, and the various domestic luxuries are supplied.

The use of gold and silver, whether in articles of furniture, dress, or decorations, depends much on the degree of refinement which may exist in any age or country. They are rarely applied, and by a few individuals, in an age of rude hospitality, of boisterous conviviality, and of inebriating gratifications ; they are the accompaniments of more elegant enjoyments and more refined manners; and if they appeared as they did in the palaces of a few princes, nobles, and prelates, they were in such union with the other furniture, with the want of neatness, not to say of cleanliness, and with the general arrangement of the whole establishment, as to form a most unappropriate combination according to the more refined ideas of the present age. 
The greater or less application of gold and silver to other purposes than money will depend much on the increase of general wealth : not meaning by wealth money or metallic treasure, but that material wealth which so much exceeds it in value. If a silver spoon be equal in value to a bushel of wheat, more spoons will be used than if it required two bushels to obtain it. In this, as in other commodities, the use will increase as the value of it measured by other commodities increases.

In the early part of the period we are now contemplating, commencing with the year 1700 , little progress was made either in refinement of manners or in the augmentation of general wealth in Europe, when compared with the progress that the latter portion of the period has exhibited.

In France, though the early part of the reign of France. Louis XIV. had been distinguished by the splendour and magnificence which his flatterers called glory, yet it had been much more distinguished by thoughtless profusion, by reckless persecution, and by efforts directed to display rather than to utility, which covered with disgrace and mortification the close of his life. The regency of the profligate Orleans found France in a state of weakness, not decrepitude; but a peaceful series of years, in spite of national insolvency and occasional hostilities, gave fresh energy to industry, whilst the voluptuous Louis XV. certainly introduced a refinement of manners. The increased 
use of plate was the consequence of this temperate advancement in prosperity and refinement. It is asserted by Necker, that the increase of plate, as ascertained from the mint of Paris, between the years 1709 and 1759, was in the proportion of seven to one.

According to the "Statistique général et particuliere de la France," published by Herbin, in 1803, the amount of the silver and gold consumed in France by the goldsmiths and jewellers was ten millions of francs, beyond that which was obtained by the melting of old vessels and old trinkets, and by burning the old lace and silks ${ }^{1}$. This, which may be called eight hundred and fifty thousand pounds sterling, rests on the authority of M. Necker, whose work is referred to by the "Société de Gens de Lettres et de Savans "," who compiled the work of which Herbin was the editor. At the time that work was published, the use of those metals had risen to near the same standard as before the revolution, when Necker wrote, but during that miserable period there had been an astonishing decline in that branch of industry. "There were very extensive fabrics of gold and silver articles at Lyons, Bordeaux, Marseilles, Strasbourg, and some other places; but the events of the revolution, the want of internal consumption, and the

1 Statistique générale, vol. ii. p. 181.

${ }^{2}$ Necker, vol. iii. p. 74. 
difficulty of exportation to foreign countries had ruined the greater part of them ${ }^{1}$."

In this estimate of the consumption of gold and silver in France before the revolution is not included that which was used for watches. In 1787 , the number of watches sold in Paris is stated, in a memoir presented to the Bureau de Commerce, at twenty thousand annually, of which one in twenty was of gold ${ }^{2}$. If we suppose an equal quantity to be sold in the rest of that kingdom, the cases of that number of watches would require as much gold and silver as would make the value of those metals consumed within France amount to somewhat more than a million sterling. A great part of the watches sold in France were, even at the time to which we refer, imported from other countries-chiefly from Geneva, but some from Neufchatel.

At the beginning of the eighteenth century the goldsmiths of Paris were under the inspection of public officers, who, by a royal ordinance of 1703 , were to attend the process of their manufacture, to ascertain the purity of the metal, and to forbid the making basins and other articles heavier than the prescribed weight. They were bound to have their furnaces and forges in their open shops, in view of the public from the street, and to affix a notice of the fineness of the articles then in the

${ }^{1}$ Herbin, vol. ii. p. 180.

2 Ibid, vol. ii. p. 172. 
process of manufacturing. This ordinance was, indeed, only the renewed promulgation of one of the year 1602. The whole number of makers and dealers in gold and jewellery was restricted to three hundred persons in Paris and the suburbs, and they formed a guild endowed with privileges and property in houses ${ }^{1}$.

The application of silver in France to various purposes of dress, furniture, and ornaments at the beginning of the eighteenth century must have been very considerable. This may be inferred from the number of articles which are specified in the ordinance of 1703 , in a catalogue framed for the purpose of fixing the parts of them on which the assay mark which indicated the fineness of the metal was to be stamped. These articles are more than eighty in number, and show in some degree what was the fashion of the age and country. Besides ewers (aguières), porringers (écuelles), snuffers, saltcellars, chafing-dishes (réchaux), perfuming-pans, warming-pans, standing waiters (soucoupes), are among the domestic utensils. Those connected with the religious practices of the age are numerous, and many of the articles must have been heavy. Among these are cru-

'See Bazinghen, vol. ii. p. 370. It appears that similar restrictions existed in London, where the goldsmiths all worked in open shops near each other on the south side of Cheapside, near St. Paul's, in houses that now are the property of the Goldsmiths' Company. 
cifixes, chalices, flagons, processional and other crosses, batons de chantre, vessels for holy water and for incense; besides chandeliers, lamps, shrines, reliquares, images, boxes for holy oil, and various small articles used in the different parts of devotion. Many parts of the dress made of gold or of silver, especially buckles for belts for the body and for the swords, are enumerated; besides the hilts and guards of the swords and sabres, and many ornaments for the harness of the war and other horses.

This long list of articles contained in the ordinance is framed to ensure the stamping of the several portions of the gold and silver articles, and to afford a security to the purchasers that they were of the legal degree of purity; but it shows that a large portion of those metals must in that age have been applied to other uses than that of conversion into coin in France.

The ordinance was not extended to articles of less than an ounce in weight, and therefore, as far as relates to gold, the greater part of the objects to which that metal was applied, such as rings for the fingers and for the ears, beads for counting prayers, and small trinkets of various kinds, were not amenable to the laws for assaying.

At the early part of the period the consumption Spain. of the precious metals in Spain must have borne some proportion to its wealth and its devotion. At the close of the seventeenth century we find 
in Arguielles that the goldsmiths and silversmiths in Spain amounted to four thousand two hundred persons. Their operations must consequently have drawn, for the purposes of ornaments and utensils, a large share of that gold and silver which came from America in the form of coin.

After the war of the succession, by which Spain had suffered severely; she appears gradually to have declined in general wealth, and probably in the application of the precious metals to purposes of luxury; for certainly there was little of luxury to be seen in the houses of even the richer classes of inhabitants towards the close of the century. This may be seen by the report of a council of state held in June, 1794, when Spain was engaged in war with the French republic, and from the state of her finances was compelled to contemplate some strong measures to obtain pecuniary resources. An account, in what manner taken does not appear, was laid before the council of the whole mass of gold and silver belonging to the churches and other religious establishments, and to private individuals, stating it to amount to eleven million forty thousand pounds sterling ${ }^{1}$. A suggestion was made to these bodies to give up to the state what could be spared from the indispensable requisites for the sacred rites and from the necessary uses of private persons; but the

${ }^{1}$ Argüelles de Hacienda, vol. i. p. 66, and vol. iv. p. 345. 
requisition was so feebly heeded, that very little accrued to the royal treasury, scarcely a sum exceeding ten thousand pounds.

A similar attempt in 1812 to obtain aid from the treasures of the religious establishments, though rigidly enforced, was scarcely more successful. The latter was at a time when the Cortes, who made the requisition, had been deprived of power over the greater part of the kingdom by the French occupation, and it is not wonderful that it should have yielded no more than the small sum of twelve thousand pounds.

But though at these periods there may have been but little of the precious metals extractable by fiscal operations, it by no means follows that there was a great paucity in the whole country. The Spaniards, from the time of the Moorish occupation, had been accustomed to hide their gold and silver from the numerous depredators; and as, after the destruction of the Mahometan power, no safe means of making interest was to be found, it is probable that a larger proportion of what did exist may have been hidden in Spain than in any of the other countries of Europe.

It would lead to an extensive and almost end-Italy, Gerless inquiry to examine into the progressive inmany, \&c. crease of gold and silver ornaments and utensils in many other parts of Europe, as in Italy, in Germany, in the eastern parts, as Bohemia, Hungary, Poland, and Russia, or in the northern 
kingdoms of Denmark and Sweden. The inhabitants of all those countries, however it may have been with the governments, increased in material wealth; and we may fairly infer that in a similar manner they must have increased in the application of that wealth to purposes of luxury, of show, of splendour, or of such gratifications of an ornamental kind as best coincided with their respective tastes. The use of gold and silver must therefore among them have become more extended; and as it descended from the higher ranks to the more numerous bodies of which the ranks below them consisted must have caused an increased consumption in that way.

The progressive steps in luxury are much more traceable by us in England than in foreign countries. We shall therefore take no farther notice of Holland, of the Netherlands, of the Hanse towns, or the independent republics of Italy, than to observe that their progress in wealth and luxury, though checked by occasional interruptions, continued generally through the whole of the century, and the application of the precious metals to the latter purpose must have been nearly in the same proportion.

England. In the reign of Queen Anne there seems, from the accounts preserved at Goldsmiths' Hall, to have been a very sudden increase in the manufacture of plate. It may be difficult to account for the fact, but perhaps the rich services pre- 
sented to the Duke of Marlborough may have stimulated the more opulent part of the nobility and such public bodies as were possessed of wealth to attempt to imitate, if not to rival, the splendid decorations of the heroic and successful general. However that may be, it seems that the mass of old silver and gold articles of furniture still remaining in its ancient form is of the fabrication of that reign. This is the case with the plate of the Duke of Devonshire, and of other distinguished families, as well as of that belonging to the Goldsmiths' Company of London and to other public bodies.

The introduction of tea, but especially the extension which it gradually received, till it has become the daily fare of almost the whole community, had an influence on the consumption of silver for small spoons. They were scarcely known in the previous reign, but multiplied in the reign of Anne, and have gone on increasing from that time to the present, when they may be counted by millions, perhaps by hundreds of millions.

Between the reign of Anne and the latter end of that of George the second, the progress of the application of silver and gold was at a slower pace ; but between 1760 and 1770 a fresh impulse seems to have been given, which has continued up to the present time, though with some variations in its rapidity. When table-spoons of silver had super- 
seded those of pewter, as they had done those of horn or wood, they were fabricated of very light weight, and such of them as are now remaining will be found to be not much heavier than the tea-spoons made in more recent times.

Table-forks are articles of late introduction; they were not universally placed at table till a comparatively recent period. Even with the higher classes of society, forks of silver had not supplanted those of steel or iron at the commencement of the reign of George III.; and it was towards the middle or end of that reign before they became universal among that class, and general among the classes immediately below them. Their use has gone on increasing; and the silver used in the making of them, with the several kinds of spoons, forms the mode in which one-half the silver consumed in England is used.

Between the years 1765 and 1780, many articles, either new in name, as tea-urns and tureens, or as tea-pots and coffee-pots, made of silver instead of other substances, were introduced. These, with silver waiters instead of those called japan, and wine-coolers, had much increased in use. Silver plates, dishes, and covers were brought down to classes of lower rank than had before been able to afford such expensive articles.

The use of watches, as general wealth was augmented, increased with it; and especially after they became the product of the labour of artisans 
who formed the separate parts upon the principle of the division of labour, and left to the mechanical artists the more delicate task of adjusting those parts, and of regulating the rate of their movements. Instead of a watch being the distinguishing appendage to a man of wealth and fashion, it has become the useful companion of all but the poorest and idlest of the community. Among even the middle ranks it has grown into use, not merely for the heads of the family, but few of the junior members, or even of the domestic servants, are without them. The increased number of watches, especially since it has been permitted to form the cases of a lower degree of fineness of the gold and silver than our standard, has been such that they must be counted by millions.

The introduction of plating with silver on copper, and especially since the manufacture has been removed from London to Birmingham and Sheffield, has caused a vastly increased consumption of silver, especially from about the year 1780 to the present time. It was necessary to advert to the fact in this part of the subject, though the extent of it will be more fully considered in a subsequent part of this inquiry.

The consumption of gold by the several descriptions of gilders towards the latter end of the period under consideration experienced a vast increase. The number of goldbeaters was tripled

VOL. II. 
in twenty years. The application of gold to the several branches of the water-gilder's art felt a similar increase, and the practice of gilding many of the larger articles of silver plate was extended. The gilding in the interior of houses had commenced, and absorbed much gold, though the progress of that particular kind of ornament had not been so great as in more recent periods. Since the fabrication of porcelain in Europe has surpassed that of China both in beauty and in use, the fashion of profuse gilding has been generally extending among the potteries in England, as well as in those of France, Prussia, Saxony, and other parts of the continent. This absorbs a very increasing quantity of fine gold, which is lost when the pieces they ornament are broken.

The most rapid increase in the application of gold during the reign of George III., and that which absorbed a greater portion of the metal than all the other modes of consumption, was the manufacture of trinkets and jewellery. Broaches, clasps, lockets, bracelets, breast-pins, necklaces, chains, earrings, and a thousand nameless ornaments which the London jewellers and goldsmiths had formerly produced, were imitated at Birmingham, and reduced so much in price as to come within the reach of a much more numerous class than had before indulged in the use of them. It is true the gold was of a lower fineness, much of it consisting of scarcely one half of that 
metal, but by various improvements in the alloys mingled with it, the ornaments looked as well at a lower cost; and therefore in this way the proportion of gold consumed was very much greater than it would have been if the standard fineness had been adhered to.

Those few who can remember the fashion of dress sixty years ago, may be disposed to think the consumption of gold to have lessened, as far as regards the lace on the clothes of gentlemen. As late as the year 1770 few gentlemen appeared -without an embroidered frock, or a laced coat of gold or silver. Even with the middle class a gold laced waistcoat formed a very common part of the dress, and gold laced hats were very general to a later period. Though this use of gold and silver lace has disappeared, and though the officers of the navy and army are less covered with lace, yet it is to be considered that their numbers in England as well as in other parts of the world have very much increased, and perhaps the consumption has not been much, if at all, diminished.

It is also to be remarked, that in this way there is but little absolute consumption. The pieces of old lace are collected and burnt, and the greater part of the precious metal is restored to its former state, and becomes fit for application to future purposes.

These remarks on the increased application of P 2 
gold and silver to other purposes than that of coin are necessarily of a general nature. The subject does not admit of any estimation approaching to statistical accuracy, and whatever inferences may be drawn must depend rather on inquiries made at a subsequent period, than on any information that can be derived from the period to which they relate. Whoever has had occasion to inquire among refiners, gold-beaters, jewellers, or goldsmiths concerning the extent of their operations thirty or forty years ago, to say nothing of more remote dates, will have found the answers he obtains doubtful and contradictory, though the same persons can give accounts of its present state, which may inspire sufficient confidence in their accuracy to be made the basis of such estimation as may be relied upon.

It is for that reason, that though we find it necessary from the plan pursued to estimate in the present chapter the proportion of gold and silver applied to other purposes than coin in Europe between 1700 and 1810 , yet we defer to a future part of the work the chief of the specific grounds by which that estimate must be be sustained. In the mean time the reader is referred to Appendix, No. 5, where sufficient proof is exhibited of the increased use of gold and silver for purposes of personal ornaments, and for decorations and utensils. It is not without much consideration of all the circumstances which ac- 
company this complex inquiry that we have arrived at the conclusion, that in the one hundred and ten years in question, the quantity of gold and silver which was converted into other objects than coin amounted to two-thirds of that which was left in Europe, after the part which was conveyed to Asia is subtracted from the total produce of the mines.

This estimate obtains some support from the views taken of it by Necker in France, who in 1789 reckons the annual amount of the gold and silver used in that country for ornaments and utensils at near one million sterling. Humboldt in 1800 estimated the amount of the two metals so applied at five million eight hundred and twentyfive thousand Spanish dollars, or one million two hundred and thirteen thousand five hundred pounds sterling. He supposes the consumption of all Europe to be to that of France as four to one, and consequently is disposed to view the whole annual demand of this quarter of the globe at four million eight hundred and fifty-four thousand pounds sterling. In the cursory view we have taken, and the subject admits of only cursory views, we should consider the consumption of England, at the time when Humboldt formed his estimate, at abqut one million five hundred thousand pounds; and that the rest of Europe may be calculated to consume about three times as much, which would make the whole about four 
million five hundred thousand pounds. It is only by different modes of calculating, on subjects in their own nature very doubtful, that we can arrive at conclusions, which after all merely approximate to accuracy.

We give, however, in one view the state of the coined money of Europe, deduced in the way here adopted, as follows :

The coin in existence at the beginning of the year 1700, being reduced by friction as stated in page 192, would at the end of 1809 amount to

To this, if added, the produce of the mines $£ 880,000,000$

From which, deducted for the trade of Asia, two-fifths

. $352,000,000$

$528,000,000$

We suppose of this that two-thirds was applied to other purposes than coin

. $352,000,000$

There would remain for coin

From which must be deducted for wear on that quantity in the period of one hundred and ten years . $154,000,000$

Leaving as the stock at the end of 1809

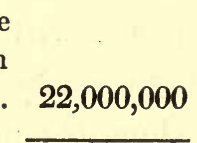
- $22,000,000$ 
putation, and the coin had increased from two hundred and ninety-seven millions of pounds in 1699 to three hundred and eighty millions of pounds in 1809, the addition would be at the rate of about twenty-eight per cent. This computation, though by a very different process, gives a result so nearly approaching to those by Forbonnais, Gerboux, and Heron de Villefosse, that it seems more entitled to confidence than that of Necker, who rated the coin of France to be nearly equal to that of all Europe, and the collective stock not much to exceed one half of this estimate.

In drawing a comparison between the prices of wheat, which in spite of the objections to it that have been stated in former parts of the inquiry we are compelled to adopt, it is necessary to take the average of a long series of years. It seemed also desirable to avoid years in which derangements of the current coin of the kingdom were in operation. On that account it was advisable not to include any of the years after the suspension of the bank payments in specie: that suspension had some effect on prices, but the extent to which it operated in various periods must have been a subject of discussion too long and too doubtful to be entered upon here. The periods for comparison are the thirty years between 1665 and 1695, and the same number of years between 1765 and 1795 . 
It appears by the Windsor prices, as kept at Eton College, that the average prices of wheat of the whole of the years between 1665 and 1695 was two pounds and sixpence halfpenny the Winchester quarter of eight gallons. The average price of the corresponding years in the following century, or between 1765 and 1795, was two pounds eleven shillings and a penny-halfpenny. By the Oxford prices in the Appendix, No. 4, it will appear that the wheat sold there, whose prices are taken at two periods in each year, viz. Lady-day and Michaelmas, was, on the average of the same two periods of thirty years, as follows: in the first series at one pound sixteen shillings and ten-pence per quarter, and in the second series two pounds nine shillings and sixpence. If these two tables of prices are classed together, the bases of the calculation will be more extended, and the rise on the century will be from one pound eighteen shillings and eight-pence to two pounds ten shillings and three-pence, and show an advance of thirty per cent on the earliest prices.

This coincidence between the increase of the stock of coin and of the price of wheat in the course of a century may be accidental, or may be local and applicable to England, and not to the countries on the continent of Europe; but as far as a judgment can be formed from the few data that can be collected, the advance was similar during the part of the period for which accounts 
are to be found. Thus in Spain the average price of wheat in the market of Seville, from the year 1701 to 1726 , was fourteen reals ${ }^{1}$ thirty-one maravedis the fanega; from 1727 to 1752 it was seventeen reals twenty-two maravedis; and from 1765 to 1787 it was twenty-six reals eleven maravedis ${ }^{2}$.

This shows a greater advance than appears by the English accounts. It may not, however, be proper to assume the price of wheat in Spain as a scale to measure the value of gold and silver with the same confidence as may be given to the price in England. It is not so universally the food of man as with us, and the variations in price are more enormous. In the hundred years we are considering, the lowest price of wheat in England was one pound three shillings and a penny, and the highest price three pounds nine shillings and four-pence, thus varying as from one to three; but in Spain the lowest price was seven reals, and the highest thirty-nine, or from one to five and a half.

Not having correct prices. of wheat in France at the latter portion of the eighteenth century, we must make the contrast between two periods at a century from each other, the first beginning with

1 The real is the twentieth part of a dollar, and is divided into thirty-four maravedis. The fanega is two-thirds of an English bushel.

${ }^{2}$ See Appendix, No. 29, to the Bullion Report. 
1616 and ending with 1645 , the second in 1716 and ending in 1745. The average of the first thirty years ${ }^{1}$ was eleven livres five sols; that of the second, seventeen livres eleven sols, six deniers for the setier of Paris, thus showing an advance at the rate of somewhat more than fifty per cent. in the century. In the same two periods the price of oats varied much more, being in the first thirty years six livres ten sols, and in the latter twelve livres eight sols, or near one hundred per cent.

The wheat-market of Dantzic is regulated more by the variations of fertility in the whole of Europe than that of any other place. Its prices depend more on the harvests of distant countries than on those from whence its supplies are drawn. It may exhibit a better scale of fertility in a series of years, but a less satisfactory one of the value of gold and silver. Without giving importance to the statement, it would scarcely be proper wholly to omit the notice of the advance in price at that great market. We have no correct list of prices at an earlier period than the year 1700. The average price from that year to 1725 was one hundred and thirty-five florins for the last of ten quarters. In the last twenty-five years of that century, from 1775 to 1800 , the average price was three hundred and thirty-seven florins for the

${ }^{1}$ Essai sur les Monnoies et sur le Rapport entre l'Argent et les Denrèes, page 181. 
same measure; showing an advance of near three hundred. per cent. ${ }^{1}$ This must have been attributable chiefly to the great scarcity of corn which was experienced in France at the beginning of the revolution, and to similar deficiencies in the supply of other countries. These, offering very high rates, induced the transportation of corn from distances in the interior of the continent to Dantzic, which could not have been borne but for the almost famine prices in other countries.

The kindness of the officers of the royal hospital at Chelsea has furnished the contract prices of the chief articles consumed in that establishment for the years 1730,1731 , and 1732 , the oldest period of which there are clear accounts; and for the years 1791, 1792, and 1793, after which the contracts were made in a different manner. It appears by the account in Appendix, No. 6, that in the sixty years the advance on bread, beef, mutton, cheese, and butter had been at the rate of twenty per cent., that on pease and oatmeal more, and that on coals still more. On salt, beer, and candles it is difficult to fix the accurate difference, as it might be occasioned by alterations in the taxes laid on those articles. As far as the account extends, it seems a conclusive proof of a gradual advance in the money-price of those kinds of neces-

${ }^{1}$ See Jacob's Corn Report, ordered to be printed by the House of Commons, 14th May, 1826. 
saries which form the sustenance of the great mass of the population of the country.

An advance in the price of so indispensable an article as wheat, or even of the prices of the general mass of commodities in Europe, would be no decisive proof of the increase of the precious metals. If the whole material wealth of a country receives a great accession, and a correspondent accession be made to the coin, prices would continue as before if the facility of circulating that coin should remain without alteration.

If we were to judge from England alone, there would be little hesitation in concluding that the mass of material wealth had increased in the one hundred and ten years, at a greater rate than the precious metals. This is obvious from the increase of the population, and from that population having been better fed, clothed, and lodged, at the conclusion than at the commencement of the century. The sources of wealth of every kind had yielded more copiously. The soil was better cultivated, and therefore yielded more of the annual necessaries of life; the surplus of exchangeable products had been augmented so that foreign necessaries or comforts could be more easily and abundantly procured. The facilities of distribution had been improved by the repairs or construction of roads, canals, rivers, harbours, and docks. The implements of industry, which diminish the use and 
extend the power of human labour, had received great improvement. A new natural power, which had not before been used, was practically adapted to perform that work which required the severe labour both of man and of animals. The application of steam to abridge labour, which had begun about the middle of the period, forms of itself an era in the history of the wealth of this country. It is not necessary to notice the vast increase of our shipping within the period, though it is both an aid to wealth and a proof of its growth, for it may be comprehended, with wheel carriages, under the class of the facilities of distribution.

A variety of causes may have contributed to this increase of material wealth in England, some of them peculiar. It may be in part owing to the wars in which we have engaged, not having been carried on upon our own territory; to our freedom from internal commotions; to the security with which property of all kinds is protected; to the sure if not the speedy operation of the laws; to the lightness of our taxation, which being drawn from property expended in consumption, is less on the mass of wealth from which it is extracted, though it is greater when calculated by the number of individuals that pay it, than is levied in any of the other countries of the civilized world.

As far as regards England, it is not necessary to prove the vast accession of material wealth within the period under consideration. In the 
continental kingdoms it is probable there has been a progress made, but it has been attended with many and lengthened interruptions in all of them, and in some the effects of those interruptions were felt during many of the years of tranquillity which followed the events of 1814 and 1815 .

Viewing Europe as a whole, comprehending with it England, and taking into the view the United States of America which had risen from low beginnings to become a wealthy and independent power, we are compelled to believe that the whole mass of material wealth had increased at a rate much beyond that which has been shown to have been the rate of increase of the precious metals. If we could be led to estimate the rate of the advance in material wealth to have been very much beyond the increase of the rate of metallic wealth, we might expect that the prices of commodities in general would have fallen instead of having risen in the period under consideration. It must, however, be borne in mind that times of internal turbulence favour the conversion of metallic wealth from articles of luxury into current coin. This operation especially was proceeding in the early part of the wars which originated in the French revolution. In France itself the most tangible property of the royal and noble families who became emigrants was their plate and jewels. The same was the case with the churches, monasteries, and other public establishments. Whether that 
plate was sold to supply the means of emigration, whether it was confiscated by the decrees of the convention, or devoted to unauthorised pillage, the greater part of it would, for the sake of more facility in its circulation, be converted into coined money. In Italy, where the churches, shrines, and religious institutions were richly furnished with ornaments of silver and gold, the greater part was seized either by the assailants or the defenders, and was converted into coin. The same course of events may be observed in the Netherlands, in Austria, in the parts of Southern Germany, and, though at a later period, in Saxony, in Prussia, and the north of Germany, and finally in Portugal and Spain.

During the first ten years of the French revolution, there could be little disposition to apply gold and silver to articles of luxury; and it is hence probable that the greater portion of those metals which were drawn to Europe from the mines was appropriated to coin. These circumstances may in some measure account for the rate of the prices of general commodities not having fallen, though the mass of material wealth had increased faster than the metallic wealth by which its value was measured.

After the destruction of the Republic under the consulate, but more under the Empire, some degree of security was given to property in France. The love of magnificence was displayed in the use of 
gold and silver utensils and ornaments, but the apprehensions of the rest of Europe from the ambitious tendency of France communicated little feeling of security to the continental kingdoms. It was not till the fall of the empire and the establishment of general tranquillity that the coin which had been borrowed from the plate was in any great measure restored to its former use.

It would be anticipating the subject of a future chapter to do more than remark that the establishment of the peace of 1815 , and the state of general security and tranquillity which followed it, have together had the effect of withdrawing from coin and applying to luxury much of the precious metals. 


\section{CHAPTER XXV.}

On the production of gold and silver from the end of the year 1809 to the end of 1829 .

WE are now arrived at a period when a great and sudden change took place in the production of the mines of gold and silver. After a space of more than three centuries, during the whole of which there had been a constant increase of the quantities obtained, and each succeeding decennial period yielding a larger portion than the similar number of years that preceded it, the whole of the mines in every part of the western continent declined greatly in their produce; and though they have in some measure been restored, it has been by slow degrees, and they are yet very far from having approached the copious produce which they yielded before their general abruption from European government.

As Mexico is that division of America which Mexico. contains the largest population, and yields the greatest portion of the precious metals, it naturally claims our first attention. No contrast can be greater than is exhibited during the three centuries which preceded its convulsions, and the twenty years which have passed since their commencement.

The troubles of Mexico began with the first 
invasion of Spain by the French. When the intelligence of the capture of the royal family and the transactions at Bayonne reached that country, the Viceroy Iturrigaray seems to have acted an indecisive part, as if balancing in his mind whether to yield to the power Buonaparte had assumed over all the Spanish dominions, or to acknowledge and obey the newly created Junta of Seville, who had claimed similar power. The old Spaniards in the capital composed a faction which had been the chief instrument of each successive viceroy in continuing the authority of Spain. They seized the viceroy, and under the pretence of an accusation of heresy, committed him to the prison of the inquisition, and from thence transferred him to Spain, where, though imprisoned for some years, his conduct was never investigated.

In the course of three centuries the mass of energetic inhabitants had become composed of the natives of the soil, but descended from Spanish ancestors. They were treated by the Europeans, who exercised political and judicial power, and were the richest part of the population, as an inferior class. Among these, called the Creoles, discontent was generated and rapidly extended; and as the great body of the Indians were easily influenced by them through the priests, a change was operated which quickly converted the languid, simple, and superstitious natives into furious, vindictive, and unfeeling revolutionists. A feeble 
and unstable provincial government of nearly two years fanned the embers of insurrection, though it suspended the explosion till 1810, when it burst forth with dreadful fury.

The priests were the chief actors in council and the leaders in the field of the armies of the insurgents. Their watchwords were, King Ferdinand, God, and the Virgin of Guadaloupe. These operated powerfully on an ignorant population, who had been taught that the old Spaniards were desirous of delivering Mexico to the Buonapartists and the Atheists. The agitation among the peasantry and miners in the provinces remote from the capital had been at work nearly two years, when, in September, 1810, it burst forth in all its fury. Hidalgo, a priest of Dolores, after an enthusiastic harangue whose effect is represented as an electric operation, was soon enabled to collect around him forty thousand men. He was speedily joined by native regular regiments, both of cavalry and infantry, and immediately marched to Guanaxuato, the capital of the mining district, a city then said to have been peopled with eighty thousand inhabitants, and to have contained silver in coin and bars to the amount of five million dollars. The garrison was small, and the inhabitants disaffected, and the hordes of Hidalgo were admitted without opposition. He established at that place a kind of government, and by the help of some officers of the army who had joined him, 
introduced some military arrangements among his followers. He established a mint for coining the silver, directed the bell-founders to cast cannon, and employed the most skilful mechanics and artists he could procure to work the mines. A deputation from Valladolid, a city of forty thousand inhabitants, invited Hidalgo to visit that place, and receiving there fresh accessions of numbers, he marched to take possession of Mexico, the capital.

The insurgents appeared before Mexico with a force of regulars and irregulars amounting to more than seventy thousand, who could be opposed but by a few, and those ill-disciplined troops. The viceroy had sent two divisions of his forces in different directions, who had united in the rear of the insurgents; this so alarmed the latter, that they abandoned the attack on the capital, and retired upon Guanaxuato. They were there attacked and defeated, and the city was occupied by the royalists, who inflicted the most summary and barbarous vengeance on the inhabitants.

Hidalgo collected the remnant of his forces and retired upon Guadalaxara, where the standard of revolt had been erected. Here again he was defeated and his army dispersed; but as fast as a reverse was experienced in one part of the country, such was the state of excitement, that equal num: bers quickly appeared in arms in some other. 
Hidalgo was however at length entrapped and put to death. Other adventurers succeeded him in the command, sometimes of large bodies, and sometimes of only irregular and fugitive bands. The most distinguished of the leaders of the bands, Rayon, Teran, and the energetic priest Morellos, were in succession taken and executed; but the restoration of tranquillity, and that of a doubtful nature, was not accomplished before the year 1815. It was, however, a truce rather than a settled peace; for a small expedition under the younger Mina, with a few hundred adventurers collected in Europe and in the United States of America, was sufficient again to kindle into action the turbulent spirits of Mexico. That bold young man with some of his followers were, after wonderful bravery and perseverance, taken and executed; but not till in their operations they had destroyed the great works of the mine of Valenciana. The Spanish authority which had been re-established over the exhausted country could do but little to restore prosperity in the short interval, till the revolution in Spain itself burst forth and soon spread to Mexico.

The Cortes of Spain, whatever love of freedom they may have expressed as regards the European peninsula, certainly discovered no disposition to diminish the authority their predecessors in power had exercised over the transatlantic dominions, 
A viceroy appointed by the Cortes arrived in Mexico just as the authority of those who commissioned him had been disowned in that country. A general who had led the Spanish armies, Iturbide, placed himself and the troops he commanded at the head of a revolution. The viceroy could not resist, and he either joined or affected to join with them, but was removed by death before his designs could be developed.

The power fell into the sole hands of Iturbide, who attempted to retain it under that kind of representative government which, whenever the experiment has been attempted, has utterly failed of success. He was nominated president, and afterwards emperor; he abdicated, banished himself, returned again to try his influence, and on landing was paid the penalty of his folly by the hands of military executioners.

In the seven years that have passed since that event, a variety of projects of constitutions have been tried, a variety of rebellions have been raised, and in spite of loans originating in the knavery acting upon the folly of Europeans, bankruptcy has ensued, and scarcely a symptom of order, and none of prosperity, has yet appeared.

This slight historical sketch of the events in Mexico for the last twenty years seemed necessary, in order to explain the causes of the defalcation in the produce of the mines of that 
country, which is exhibited between that period and the preceding one of the same number of years.

The greatest contrast was between the years 1809 and 1812. In the first of these, the money coined at the mint of Mexico was twenty-six million one hundred and seventy-two thousand nine hundred and eighty-two dollars in gold and silver; and in the second only four million four hundred and nine thousand two hundred and sixty-six. In the latter years, indeed, other mints were established-one in Durango, which coined eight hundred and eight thousand seven hundred and ninety-two; and another in Zaccatecas, which furnished nearly one million five hundred thousand.

Besides the destruction of the works, which was considerable, the withdrawment of the capital employed in mining had a most injurious effect. The capitalists, whether engaged in mining, in commerce, or in agriculture upon a large scale, were disposed to fly from a country liable to the plunder and oppression of riotous and destroying mobs. We learn from Mr. Ward's work, that. though, after the suppression of the insurgents in 1815, some small Spanish capitalists prosecuted successfully some works at Catorce, Zaccatecas, and Sombrerete, yet, on the declaration of independence in 1821, most of them withdrew their capitals and returned to Spain or France, 
some with sixty or seventy thousand dollars. Thus the country suffered a loss which none of the successive governments upon the republican plan were enabled to repair, because no confidence could be placed on the stability of any laws that were enacted, or on that of the individuals to whom the execution of them were committed.

Whilst Mexico and the continental Spanish settlements in America have been injured by the flight of the capitalists, who were, generally speaking, the most intelligent, honest, and active part of the community, the Island of Cuba, and the southern part of Spain itself, and, in a less degree, the south of France, have been much benefited by the accession of capital which the refugees have transferred to those districts, though it was only the remnant of their former fortunes.

Mr. Ward, in his valuable work on Mexico, has communicated several facts relating to the defalcation in the mines during the fifteen years of the civil wars, which serve to show the most prominent districts where the diminution was felt. "In Guanaxuato," he says, "the amount of the precious metals diminished from eight million eight hundred and fifty-two thousand four hundred and seventy-two marcs of silver, and twentyseven thousand eight hundred and ten mares of gold (the produce of the fifteen years preceding 
the revolution) to two million eight hundred and seventy-seven thousand two hundred and thirteen marcs of silver, and eight thousand one hundred and nine marcs of gold. At Zaccatecas the difference appears to have been inconsiderable, amounting only to a decline of two million one hundred and sixty thousand nine hundred and sixty-three in the fifteen years of convulsion, as compared with the immediate period of the same length which preceded it ${ }^{1}$."

The mines of Sombrerete declined in produce from five hundred thousand to three hundred thousand annually. The produce of the mines of Catorce, which was second only to that of Guanaxuato in the amount of silver raised, being nearly three millions of dollars annually, was so reduced as to yield, on the average of the fifteen years from the commencement of the insurrections, no more than five hundred and ninety-nine thousand four hundred dollars. The produce of the Biscaina vein at Real del Monte in seven favourable years before the revolution was six million of dollars, or eight hundred and fiftyseven thousand and forty-two per annum; and from 1809 to 1823 it only yielded, in all, two hundred thousand dollars, or at the rate of fourteen thousand two hundred and eighty-five on the average of the period.

${ }^{1}$ See Ward's Mexico, vol. ii. p. 19. 
" If," says Mr. Ward, " it were possible to obtain returns from the other mining districts, the disproportion between the produce before and after the year 1810 would be found to be equally striking. In each district the principal mines were abandoned, the machinery was allowed to go to ruins, and the silver raised was merely the gleanings of more prosperous times; the workings (where any were attempted) being confined almost entirely to the upper levels ${ }^{1}$.

The only exception to this general decline was in the mines of Tasco, which was a military station constantly defended by a numerous body of royalist troops. Though once taken by the insurgents, it was speedily retaken, and the Tribunal de Mineria undertook to work the mines which had formerly been the property of Labord, a man celebrated for wealth acquired by mining, and their operations were attended with such success that the annual produce amounted to four hundred thousand dollars.

"It is a fact," remarks Ward, " universally admitted, that in almost all the mining districts, although the towns have been ruined by the emigration of the wealthy inhabitants, whose capitals were formerly invested in mining operations, the lower classes have, throughout the revolution, found means to draw their subsistence from the 
mines. Under the denomination of buscones, or searchers, they have never ceased to work; and although, from the want of method in their operations, they have done the most serious injury to the mines themselves, they have in general contrived to extract from the upper levels, or from the old workings, neglected in better times for others of greater promise, a very considerable quantity of silver. This desultory system is still pursued in many parts of the country, and at Zürmăpān, Zăculapăn, el Dŏctōr, and many of the northern districts, a large population is even now maintained by it ${ }^{1}$."

The silver obtained during the revolutionary convulsions which agitated the country with more or less violence during the whole period we are considering was of very various degrees of fineness, as appears by the dollars coined both at the royalist and the insurgent mints. Much of the silver coined in that time in those places was so impure from the mixture of other substances arising from the haste with which it was necessary to convert it into coin, that at the present time it can only pass current at a discount of from fifteen to twenty per cent.; but, on the other hand, much of the gold contained in the silver, which was considerable in some of the mines, was not sepa- 
rated from it, partly owing to there being no establishment for that purpose near the mines, but chiefly from the despatch which the domestic state of affairs rendered indispensable, in issuing the coined money. Many millions of these last dollars in the course of circulation found their way to Europe, when the refiners in London and Paris, to their great gain, soon separated the gold from the silver. The dollars of that description have at length almost wholly disappeared, but their melting has added considerably to the stock of gold in Europe.

Mr. Ward has traced with much inquiry and apparent accuracy the effect which the melancholy political events of Mexico have had on the product of the chief commodities of the territory, gold and silver. He very properly has judged the quantity of coin fabricated ${ }^{1}$ as the best scale by which to form a judgment, and has corrected his estimate by what information he could obtain respecting the actual produce of the mines, and by the number of dollars which were exported to other parts of the world.

He has made a different division of the series of years from the one here adopted, having framed tables of fifteen years each,-one from 1796 to 1810 inclusive, the other from 1811 to 1825 ; 
whilst, in pursuance of our general plan, the view we now take must be of twenty years, from 1810 to 1829 , both years inclusive. Mr. Ward's returns come down no lower than the end of the year 1825, and there are consequently the four years from that time to the end of 1829 in which we must rely on information from other and uncertain sources, though analogy will be a sufficient guide to prevent any error of consequence. Directions have been sent to our diplomatic residents in the several mining countries, in consequence of a motion made by the Marquis of Lansdowne in the House of Lords in 1830, to transmit accurate accounts of the gold and silver they have recently yielded, but the returns to those orders have not yet arrived. The inspection of them would have been beneficial to this inquiry, but though their details must be dispensed with, they cannot be of much effect on our calculation of the whole period of twenty years which we are now reviewing.

Accounts are continually received of the advances made in mining operations. The writers are, for the most part, men engaged in various employments for the benefit of the companies of Europeans who have embarked capitals in the Mexican mines. Such persons are necessarily sanguine in their expectations, and are not likely to form calculations of the future produce of the mines below what may be realised: they are more 
likely to fall into the opposite error, and rather to over than under-state the expected produce. The highest estimate of what may be the actual coinage does not carry it higher than twelve million dollars, which it is said "will probably be attained by the year 1830."

A periodical work entitled the "Quarterly Mining Review," four numbers of which have appeared in London, gives a variety of details of the operations of the several adventurers in America, into which it is not within the compass of the plan of this inquiry to enter. It is, however, impossible to go through the pages of that work without coming to the conclusion that whatever may be the future products of their undertakings, they have not had hitherto the effect of increasing the quantity of gold and silver raised in Mexico to an extent much beyond what was produced in the year 1825, when their works had scarcely commenced. In that year, by the statement in the Appendix, No. 7, it is seen that the mints of Mexico, Guadalaxara, Durango, and Zaccatecas together produced ten million seven hundred and forty-two thousand eight hundred and sixty-five dollars. As some progress may have been since made, we can scarcely be subject to any error in allowing for the years 1826 and 1827 the product to have amounted to eleven million five hundred thousand dollars, and for the years 1828 
and 1829, twelve million dollars. Upon this mode of calculating, the whole gold and silver which Mexico yielded in the twenty years from the beginning of 1810 to the end of 1829 would amount to two hundred and twenty million forty thousand two hundred dollars, or an annual average of eleven millions, being, at the rate hitherto assumed of four shillings and two-pence the dollar, in sterling money two million two hundred and ninety-one thousand six hundred pounds.

Besides that which was coined into money, there appears also to have been produced some silver in bars and some gold in ingots, which were delivered to the treasury. It is shown in the Appendix, No. 7, that this, in the thirty-five years from 1791 to 1825 , was about ten million five hundred thousand ounces of silver, and one hundred and fifteen thousand one hundred and thirty ounces of gold, amounting to near three million pounds sterling, or on the average of the thirty-five years to eightyfive thousand seven hundred pounds yearly. This sum is, however, counterbalanced by a greater amount of the precious metals, which, strange as it may appear, Mexico actually imported from Europe. We find from Mr. Ward ${ }^{1}$ that three hundred and ninety-six ingots of gold and four thousand two hundred and sixty-three ounces of doubloons, amounting together to one million six hundred 
and thirty-six thousand and forty dollars, were remitted from London by the house of Goldsmidt and Co., as a part of the first loan ; which sum was recoined and included in the coinage of 1825 , and seems to account for the excess of gold coined in that particular year being so far above every other that had preceded it. We have the same authority for the fact that about that time the United Mexican Company remitted from London three hundred thousand dollars in gold.

These amounts were thus nearly equal to the bars and ingots brought to the treasury in those years; and we therefore may rest satisfied that the average annual amount of the produce of the mines in the twenty years from 1810 to 1829 could not exceed, if it amounted to, eleven million dollars.

In Guatimala, or as it has been recently denominated the Republic of Central America, it appears some small portion of both the metals have been produced and coined into money. Whatever of gold and silver had beẹn collected in Guatimala was included in the returns from Mexico before 1820. Since that period a mint has been established, whose operations may be judged of from the following account, obtained by a late visitor in that country, who, from his official situation must have been enabled to procure correct information ${ }^{1}$.

1 Thompson's Narrative of a Visit to Guatimala, p. 520. 


$\begin{array}{cccc}\text { Year. } & \text { Marks of silver. } & \text { Marks of gold. } & \text { Value in dollars } \\ 1820 & 41,300 & & 351,127 \\ 1821 & 45,808 & & 389,376 \\ 1822 & 16,214 & & 137,821 \\ 1823 & 34,628 & 146 & 314,202 \\ 1824 & 6,475 & 526 & 126,578 \\ \begin{array}{c}\text { First six } \\ \text { months of } \\ \text { I825 }\end{array} & 12,155 & 253 & 127,751 \\ & & & 1,446,855\end{array}$

This amounts to three hundred and one thousand four hundred and twenty-eight pounds sterling in the five years and a half. From the unsettled state of public affairs in that district since 1825, it cannot be supposed much improvement has been experienced, and it is not probable that the four years and a half which have passed since the termination of the above statement could have yielded more than at the recorded rate, or that the whole of the ten years from 1820 to 1829 produced more than half a million sterling.

The most melancholy picture presents itself in this, as in every portion of Spanish South America to which our views can be directed. It is not the business of this inquiry to trace the causes of the sufferings that have been endured in the smaller portions of that country, nor even to notice them farther than as they may have effected a diminution in the products of the precious metals.

Columbia, as the ancient Spanish viceroyalty of Columbia. New Granada is now called, including what was 
formerly the government of Carraccas, has, perhaps, suffered more, and for a longer period, than any other part of the southern continent. Its chief produce, as far as our purpose requires notice, was gold. This was procured in two ways: either by alluvial washing, or by river washing. The first of these modes was practised exclusively by slaves; and some proprietors of those unfortunate beings destined them to that occupation alone. The auriferous soils are moist in tropical climates, and peculiarly unhealthy; and the excessive labour required a constant supply to keep up the number of labourers. When the internal troubles broke out in 1810 and 1811, those who obtained possession of power issued decrees pronouncing freedom to the slaves, which, with whatever intention it might have been designed, only increased the misery of their condition; for wherever they were found they were pressed into the military service of the several contending factions, who happened to gain a temporary superiority in any of the districts.

For some years past this operation of alluvial washing for gold has been confined to secluded individuals, who by their distance from the immediate seat of hostilities continued the employment, but with very little profit. This kind of labour has been generally diverted to others of a more profitable description. The soil on the alluvial land is naturally fertile, and with little 
industry yields rich returns; and on good authority we are assured that, "Lands which were formerly only occupied for the purpose of gold washing, have been converted into the rich fields of Rio Negro, Medillin, and Antoquia, where scarcely any persons now occupy themselves with gold washing." The river washing is at present the most extensively practised. The sand at the bottom of the rivers abounds in particles of gold and platina; but this labour is attended with little profit. It is carried on by an indolent mixed race of independent peasants, who have few wants, and who, by some exertion and occasional success, gain sufficient to subsist on very scanty resources. According to the reports which are entitled to most credit, the chief supply of gold has been derived from this kind of labour, but the representations of its quantity are liable to much exaggeration; and the accounts transmitted to Europe having been mostly written under the excitement of the temporary mining mania which prevailed a few years ago, should be received with great doubt, and believed with great hesitation.

We know, generally, that gold and silver in Columbia, as in other parts of South America, only circulate when converted into coin; that the interest of money in the form of coin is very high, according to several accounts from one to two per cent. per month with the best security, and that 
therefore it must be the natural tendency of each to convert gold dust into doubloons, or the half, quarter, or eighth parts of doubloons, as fast as the mints can coin them.

It is, then, on the produce of these mints that reliance must be placed in calculating the gold and silver which the different modes of gold washing yield. As the coining apparatus is bad, and the work performed is slow, there is, or was, for we have heard that great improvements have been lately introduced, a delay in the operation which, when interest was so high as we have stated, led to the introduction at the mints of some gold collected by private persons in the form of dust. The directors of the mint at Bogota purchased such gold dust of those who had collected it, and coined it into doubloons and their subdivisions. By this operation a gain was made, between 1810 and 1823, of six hundred and seventy-seven thousand seven hundred and forty-six dollars, or one hundred and forty-one thousand one hundred and eighty-five pounds sterling. This gain, however, did not far exceed the current rate of high interest then paid in transactions between private individuals.

There are two mints in the Republic of Columbia, at Bogota and Popayan. No exact accounts have been procured later than the end of the year 1825 , but there is no reason to suppose 
that any great alteration has taken place in the four years after that date, and we may safely admit the presumption, that the average of those four years has been the same as the average of the four years that immediately preceded them.

The portion of silver produced in Columbia, as appears by the mint returns, is very inconsiderable, though sanguine adventurers have represented it as a most abundant substance. What is, however, afforded, is chiefly found impregnated with a large proportion of gold. In the mine of Momarto, which yielded the most, the metal is said to have consisted of three parts silver, and one part gold. This metal was then ground to powder, and in that mixed state conveyed to the mint and sold, where the two metals were separated and then coined.

An account of the gold and silver coined at the mint of Bogota from the year 1810 to 1825 , and calculated to the end of 1829 :-

\begin{tabular}{|c|c|c|c|}
\hline Year. & Dollars in gold. & Dollars in silver. & Total. \\
\hline 1810 & $1,004,969$ & 9,137 & $1,014,106$ \\
\hline 1811 & $1,017,753$ & 9,037 & $1,026,790$ \\
\hline 1812 & $943,573\}$ & 19,550 & $2,109,67$ \\
\hline $\begin{array}{l}1813 \\
1814\end{array}$ & $1,146,5525$ & & \\
\hline 1815 & $\left.\begin{array}{l}1,110,007 \\
1,062,650\end{array}\right\}$ & 53,775 & $2,226,93$ \\
\hline
\end{tabular}

Carried forward 6,377,503 
Year.

1816

1817

1818

1819

1820

1821

1822

1823

1824

1825
Dollars in gold.

Dollars in silver.

Brought forward 6,377,503

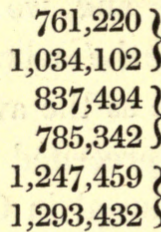

$1,037,007$ ?

$759,366\}$

576,496 ?

$573,649\}$
40,800

37,400

64,025

41,012

not given,

average assumed
1,836,122

$1,660,236$

$2,604,916$

$1,877,385$

$2,050,880$

Dollars 16,407,042

Supposing 1826, 27, 28, and 29 to have been equal to $1822,23,24$, and 25 , it would be .

$3,928,265$

20)20,335,307

Average of the years

$1,016,760$

Or in sterling, annually

$£ 211,708$

The gold and silver which are yielded in the southern part of Columbia, including that which was formerly a part of Peru and then called the kingdom of Quito, but now a department of Columbia, are coined at the mint of Popayan. The returns from thence are as follows: 
Account of the gold and silver coined at the mint of Popayan from 1810 to 1825.

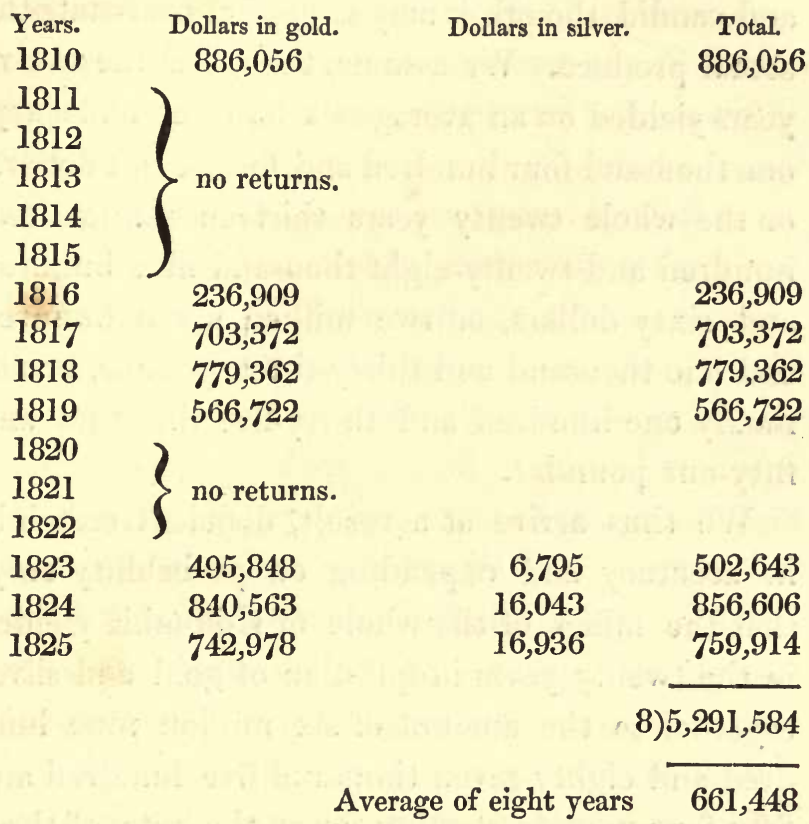

This account, deficient as it is, is the only document we have been able to procure of a statistical kind, and as the least unsatisfactory way of framing any calculation, it has appeared best to assume that the eight years of which there are no accounts, and the four years since 1825 , were as productive as the average of the years for which we have returns. The want of accounts probably arises from the excess of turbulence and the continued internal agitations of the several years. Perhaps that average is higher than can be justified, but as 
it will give a result different from the views we have formed, it may be admitted at least as fair and candid, though it may somewhat over-state the actual produce. We assume, then, that the twelve years yielded on an average six hundred and sixtyone thousand four hundred and forty-eight dollars, or the whole twenty years thirteen million two hundred and twenty-eight thousand nine hundred and sixty dollars, or two million seven hundred and one thousand and thirty-three pounds, or annually one hundred and thirty-five thousand and fifty-one pounds ${ }^{1}$.

We thus arrive at a result, deficient certainly in accuracy and depending on probability only, that the mines of the whole of Columbia yielded in the twenty years in question of gold and silver together to the amount of six million nine hundred and eighty-seven thousand five hundred and fifty-four pounds sterling, or at the rate of three hundred and forty-six thousand seven hundred and fifty-nine pounds annually.

We have given no importance to the attempts

'An anonynous work published by Murray in 1827, by an English officer in the Columbian service, says, page 304, "The quint or fifth of the gold yielded to the government this year (1826) thirty-two thousand seven hundred and fortyseven dollars, but the minister anticipates for the present year an improvement in this branch of the revenue which will raise it to fifty thousand." If this be a correct statement, the estimate here made of the recent produce of Columbia must be far too high. 
made by joint-stock companies in England to work mines of the precious metals in Columbia. They do not appear to have had any effect in increasing the products, nor are the prospects of future operations more cheering than the retrospect of the past transactions.

The ancient Spanish viceroyalty, now the re- Peru. public of Peru, was highly productive of gold and silver up to the troubles which agitated the country. These commenced in 1810, but were not severely disastrous till 1814, when the mines gradually sunk till 1820. Then a kind of revival was perceived, till the operations carried on from Chili under the direction of General San Martin and Lord Cochrane created fresh sufferings. Afterwards, the invasion from Columbia by Bolivar seems to have renewed the distress and diminished the products of the mines. Not only the failure of the mines, but the banishment of the most wealthy, active, and intelligent inhabitants, the old Spaniards, contributed to deprive the country of that capital without which mining can be but feebly conducted.

The banishment of the proprietors was carried to such an extent that, though they were happy to escape with their lives and the wrecks of their property, there was exported from Peru in the six years between 1819 and 1825 double the quantity of gold and silver which the mines had yielded in those years. 
Within the period we are considering no statistical returns have been procured except of the silver for the first eleven years, which are as follows :

\begin{tabular}{lr} 
Year. & $\begin{array}{c}\text { Dollars. } \\
1810\end{array}$ \\
1811 & $4,433,581$ \\
1812 & $3,963,566$ \\
1813 & $3,659,282$ \\
1814 & $3,409,594$ \\
1815 & $2,776,760$ \\
1816 & $2,494,422$ \\
1817 & $2,924,627$ \\
1818 & $2,653,042$ \\
1819 & $2,755,592$ \\
1820 & $2,942,244$ \\
& $3,573,907$ \\
\hline & $35,586,617$
\end{tabular}

The only authentic information respecting the state of the mines comes down no lower than the year 1826. At that time high expectations were indulged of a great extension of mining operations which was to arise from the application of English capital. The account of the calamitous crisis with which England was visited at the end of the year 1825 had not reached Peru when the descriptions of the state of the mines here referred to were collected, and they must be considered as dictated in some measure by the high state of excitement which was then in action in Peru.

"Owing to the revolution which broke out at Lima in 1820, no documents or even intelligence 
can be obtained, as the tribunal of the mines had ceased to exist. The machinery of the mints at Lima and Cusco had been wantonly injured, and all information from them was materially checked. In 1825 no more than eight hundred thousand dollars were coined, and in the present year (1826), though the mints are conducted under British superintendence, it is not expected that more than one million five hundred thousand will be coined. The principal mines have been abandoned, the chief causes of which have been, the want of quicksilver, the decrease of population, and the inundations. It is, however, not unlikely that the whole of the mines between 1820 and 1825 may have yielded near three millions of dollars in value annually, as much of the silver in a rude state was taken away from the mines by the different armies that occupied the country."

The only estimate which can be formed of what amount has been produced since 1825 must be from some communications on the existing state of the mines in 1826, which are entitled to credit from the character of the individual who has transmitted them; though subsequent events would compel us to make some allowance for the sanguine expectations then entertained.

The following is an abridgment of the communications here referred to of the state of the mines in the several departments into which Peru has been divided by its republican rulers. 
Intendancy of Truxillo, now de. partment of Libertad.

The mines of Hualgayoc and the adjoining hills are the richest in Peru. The average returns for many years were seven hundred thousand dollars, but since 1802 the produce has gradually decreased, and yielded in 1825 only three hundred and seventy thousand dollars. Two British merchants have lately purchased some very valuable mines in these hills, and have proceeded to England for the purpose of engaging engineers and purchasing machinery.

Intendancy The celebrated mines of Pasco are situated in of Tarma, now department of Innin.

this department. They abound in silver, copper, iron, and lead, and good coal is also found in the same neighbourhood. These mines, about the year 1794, are said to have yielded more than two million dollars. An English company has purchased some of the principal mines of Pasco, but doubts are entertained as to the permanency of this company, as the subscribers are alarmed at the expenses already incurred and at the still further calls upon them.

Intendancy, now department, of Lima.

Intendancy of Guamanga, now department ofAyachuco.

The mines in this department, though at work in 1820, are all now abandoned.

The mines in this department formerly produced considerable quantities of silver, but are now abandoned from having become inundated, and thus requiring a large capital to render them again productive.

Intendancy, The mines of Callioma are still productive, but
now department, of Arequipa. from those of Huantajaya and Santa Rosa only a 
small quantity of silver is now produced. The mines of Huantajaya have lately been purchased by an English merchant, who has proceeded to England for the purpose of engaging a company to work them. The disadvantage of these mines is the want of fresh water.

Silver abounds in this department. The famous Intendancy, . Sine mine of Layacota is now the property of an En- ment, of glish merchant. The principal obstacle to its Puno. working is the great lodgment of water in the shaft, which, it is said, can be drained off by an old adit.

It will be seen by these extracts that the chief hope of restoring the mines of Peru to a state of tolerable productiveness depended on the expectation that the various companies in England formed, or about to be formed in 1825, would furnish the capital required for their restoration. The fate of those companies is now too well known to afford any expectation that they have supplied any effective aid since 1826. We therefore conclude, that the mines which had been abandoned at that time have continued in the same dismantled and unproductive state.

For the purpose of completing the plan here adopted, it is necessary to have recourse to some assumption, and we shall take as the ground of that assumption the highest estimate that is to be found in any accounts we have been able to collect. This, written in 1826, expresses an expecta- 
tion that the whole of the mines may produce more than one million five hundred thousand dollars, which shall be taken as two million.

The whole production of silver in Peru then may be brought into one view as follows :

Dollars.

In the eleven years from 1810 to 1820 , both years included

In the five years, 1821, 1822, 1823, 1824, $35,586,617$ and 1825, the same amount as in the five preceding years, which appears to be . In the four years, 1826, 1827, 1828, and 1829 , at the annual rate of $£ 2,000,000$

Amount of silver in twenty years

$58,436,029$

Dufing the period in question we have no returns of the gold from Peru, except for six years from 1800 to 1805 , in which the produce was 1,875,723 dollars, or an annual amount of 312,620 dollars. The state of the hostilities must have diminished the produce in the fourteen subsequent years; but we may estimate the whole twenty years at that rate, being

$6,252,400$

Produce of gold and silver

Or in sterling

Or annually

Buenos Ayres.

The Viceroyalty of Buenos Ayres or La Plata, which, as has been before stated, comprehended in its western limits the district since erected into what has been called the republic of Bolivia, seems to have suffered more in its mining operations than 
any other part of Spanish America except Columbia. The produce of the precious metals before the time of its revolutionary sufferings amounted annually to about four million two hundred and sixty thousand dollars, but since the commencement of those disastrous events it has gradually at first and rapidly of late years declined. This seems to have been owing in a great part to the richer proprietors having been attached to the cause of Spain, and to the Indians having followed their benefactors. But when the Liberators invaded those peaceful spots, the proprietors were either banished or put to death, and their followers pressed into the military service of the invaders. Two English travellers have visited those countries, and though it is evident from the spirit of their works that their feelings were engaged on the side of the invaders or liberals, yet the picture they give of the effects of this liberal desolation are so connected with the subject of decreased production of the precious metals that they are highly deserving of attention. Their description, though here only applied to one particular portion of the liberated continent of South America, may with few exceptions be considered as equally applicable to every part of that vast tract of country.

Captain Andrews passed from the city of Buenos Ayres by Juijui Saltá and Tucuman to Potosi. Nothing can be more melancholy than the description he gives of the whole district, but espe- 
cially of the mining operations: he says (vol. ii. p. 17), "the celebrated mines of El Pan de Azucar, Rosario, and the golden Lavaderos of the Rinconada, were abandoned." "The Bineros or Lavaderos of the province so much spoken of as producing abundance of gold in dust, grains, and scales, yielding never less than twenty-three carats, have been abandoned, though not one-third worked." At Tupiza the captain examined some mines on which General Olaneta, who fell in defence of the Spanish authority, had expended half a million of dollars. The machinery in these mines was in a most dilapidated state, and the adits, though not quite finished, were already nearly choked up.

The account the same author gives of the neighbourhood of Potosi, which he visited in 1826, contains striking proofs of a vast decline. "From a population of one hundred and thirty thousand at the commencement of the revolution, Potosi dwindled to nine thousand in 1826, but during the administration of General Miller had increased again to eleven thousand ${ }^{1}$." At one period there were one hundred and thirty-two stamping mills at work, but when Captain Andrews was there no more than twelve were employed: he says, " many of the emigrant proprietors obtained leave to return and claim their property. These persons, however, have not a shilling to set the works 
going again, all their money having been swept away."

Sir Edward Temple visited the same districts in the same years as Capt. Andrews, and like him seems to have been employed to purchase mines for some of those numerous abortive companies at that period formed or projected in England. His account differs but little from that of the other traveller. "The population of Oruro," he says, "does not exceed four thousand souls, and those are in great indigence, owing to the destruction of the mines of silver and tin which formerly supported a brisk and extensive commerce, now nearly extinct from want of those resources which were absorbed in the all-consuming civil war ${ }^{1} ., \mathrm{He}$ asserts that all the mines in Potosi put together do not produce near two hundred thousand marcs of silver yearly; that the districts of Potosi, Portugalette, and Chayanta, yielded in 1826 of silver one hundred and seventy-seven thousand one hundred and twenty-seven marcs, or about one million four hundred thousand dollars, and that by subsequent disturbances that produce had been lessened ${ }^{2}$. This amount is represented to be derived "from the accumulated scrapings of many needy individuals, employing a few thousand dollars for the means of mere subsistence, beyond which they

1 'Temple's Travels, vol. ii. p. 29.

2 Idem, vol. ii. p. 252. 
have not funds to work." It may be naturally conceived that persons of the class which are here described may be easily driven from their labour whenever civil dissensions expose their compendious but petty treasures to military plunder.

No better evidence can be given of the want of capital in these countries than one fact which Temple relates. He was enabled to lend a sum of money upon the security of goods of gold and silver, which were deposited in his hands, at the enormous rate of two and a half per cent. per month; and this was considered a favour, the current rate of interest in Potosi having risen from three to four per cent. per month, whilst in the city of Buenos Ayres the rate was only fifteen per cent. per annum ${ }^{1}$.

The same author remarks, "that the mania of unceasing change, which has so conspicuously marked the conduct of the South Americans in their plans and modes of government, has recently extended with a violence that has again thrown into convulsion nearly the whole of the vast continent."

The evils of the revolution have visited this district with greater weight than any other part of America. It was early invaded from Buenos Ayres, and a body of troops from that city under Puyredon took possession of Potosi as early as 1812, and after

1 Temple, vol. ii. p. 217. 
having plundered the miners and other inhabitants, were compelled to abandon the place, but carried with them the greater part of the metallic wealth. Since that time it has known no tranquil times. It may therefore be naturally concluded, that very little industry could have been applied to mining during the whole twenty years from 1810 to 1830 .

It will not be calculating too low if we estimate the whole period to have yielded in gold and silver the annual amount of . 1,500,000 dollars, or in the whole period . $30,000,000$ dollars, or in sterling money . 6,305,000 pounds, or on the average of the 20

years

315,250 pounds.

During the twenty years under consideration the Chili. produce of the mines of Chili has varied very considerably, but especially that of silver. In the two years 1810 and 1811, the amount of the latter metal was four hundred thousand dollars. In the year 1812, the mines of the Sierra Amarga at Huasco were accidentally discovered, and the produce of that and the following year amounted to about one million six hundred thousand dollars. In 1814 and 1815, partly from the exhaustion of the veins, and partly from the troubled state of the country, the quantity yielded declined to one half, or eight hundred thousand dollars. From 1815 to 1825 , the produce gradually diminished, and on the aver- 
age of those years afforded annually three hundred and twenty thousand dollars. In the years since that, by a private communication from an intelligent person, a resident in Chili, lately arrived in this country, the annual amount is stated to have continued at the same rate up to the present time. According to this view the whole amount of silver produced in Chili in the twenty years from 1810 to 1830 will appear to be seven millions two hundred and eighty thousand dollars.

Gold was formerly collected in Chili in much larger quantities than it has been of late years. The mines of that metal have fallen into disuse, partly from the scarcity of labourers, and partly from the greater wages that can be obtained by miners from working in the silver, but more especially in the copper mines.

During 1810 and 1811, before the revolution began, the produce of gold continued as before at. nearly one thousand pounds weight yearly; from that to 1815 the amount may be taken at not more than five hundred pounds weight; from the end of 1815 to the beginning of 1826 , at four hundred pounds, and for the last four years at one hundred and eighty-five pounds.

It appears by this estimate that the whole of the gold produced in Chili in the twenty years from 1810 to 1829 , both years included; amounted to forty-eight thousand six hundred and forty 
pounds, or five hundred and eighty-three thousand six hundred and eighty ounces, which, when valued at sixteen dollars to

the ounce, make . . 9,338,880 dollars, to which adding the silver

as before estimated . 7,280,000 dollars, showing the whole product

to be . . . 16,618,880 dollars, or in sterling money . 3,462,266 pounds, or on the average of the

twenty years

173,113 pounds.

The produce of gold in Brasil has for many Brasil. years been declining. The process of that declension from 1752 to 1795 is to be seen in the Appendix, No. 8, when during that period it fell off more than one half in the province of Minas Geras, which was then and still is the chief source of gold. Since that period we have been able to collect no statistical reports of the amount of the gold obtained, though, from the relations of the most intelligent travellers who have visited Brasil, there has been a continued decrease in the product.

W. C. von Eschwege, a scientific German, who paid much attention to the gold washings, states the amount of gold yielded by Minas Geras as three-fourths of that in all the provinces, and affirms that, when he visited Brasil, the whole amount of the duty of one-fifth was three hundred and 
sixty thousand cruzados ${ }^{1}$. There are two kinds of cruzados, one the old of four hundred rees, the other the new of four hundred and eighty rees. Taking the medium of these, or that the cruzados are one eighth part of a pound sterling, the amount of the quinto, or duty of a fifth, would be forty-five thousand pounds, and the gross produce five times as much, or two hundred and five thousand pounds. We are disposed to think that this was near the average production of the period under consideration, from the coincidence to be found in the casual remarks of other travellers; thus Koster, an Englishman, who resided in the north of Brasil, states the amount of the gold as two hundred thousand pounds. Major von Schäffer, who visited the mining provinces of Brasil in 1822, asserts that no more than twentyfour arobas of gold were delivered in to the smelting house at Villa Rica, in Minas Geras, in the preceding year ${ }^{2}$. This would make the decline in ten years to be from two hundred and five thousand to thirty-five thousand pounds.

There was probably a decline after the year

- Journal von Brassilien, oder vermischte nachrichten aus Brassilien, auf wissenschaftlichen Reisen gesammelt, von W. C. von Eschwege, Weimar, 1818.

- Brassilien als unabhangiges Reich geschildert vom Ritter von Schäffer, Major der K. Brasillischen Ehrengarde, \&c. \&c. Altona, 1824. 
1812. When the war between England and the United States of America began, the price of cotton rose so high, that the labour of the slaves in Brasil was found to be much more profitably employed in the cultivation of that commodity than in washing the sands for gold; and since that war has ceased, the cultivation generally of tropical productions has been the most beneficial application of labour.

It is shown by Eschwege, in an official document which he procured in Brasil, that the employment of about sixteen thousand persons in the six hundred and thirty-one lavras or gold washings in Minas Geras obtained gold to the amount of three hundred and eighteen thousand seven hundred and ninety milreas, or seventy-nine thousand six hundred and ninety-seven pounds. From this must be deducted one-fifth for duty to the crown, or fifteen thousand nine hundred and fifty-nine pounds, thus leaving sixty-three thousand six hundred and thirty-eight pounds for the purchase of slaves to replace such as might be worn out by the severe labour, and to maintain the whole number of the persons employed ${ }^{1}$. As the net amount of the gold seems to be little more than four pounds per head, it cannot appear extraordinary that such a description of industry

${ }^{1}$ See Appendix, No. 9. 
should be abandoned and exchanged for the more profitable employment of cultivating sugar, cotton, coffee, and the other productions of the surface of the country ${ }^{1}$. It seems probable, from what is known of the state of society in Brasil, that the slaves of those employed in seeking for gold are so far cultivators of the soil as to raise sufficient food for the workmen of the lavras: but if that be the case, and their subsistence is so procured, the small apparent profit would be insufficient to pay interest on the capital invested in slaves, especially in districts where, as in Minas Geras, the common rate of interest is one per cent. per month. The prospect of great sudden gain, which is always before the eyes of those seeking for the precious metals, may induce numbers to continue an employment which may be clearly seen by the

1 Count Mollien, in his Travels in Colombia, remarks that " a mine which employs sixty slaves, and produces twenty pounds of gold annually, is considered a good estate." At this rate each man is calculated to produce the third of a pound. The gold found there is only of eighteen carats, called oro bajo, and worth about forty pounds sterling. The labour of each slave, then, produces thirteen pounds six shillings and eight-pence. In Colombia, however, provisions are by no means so cheap as in Brasil, and the constant state of internal hostilities has made labourers scarce, as the negroes are ready or are compelled to become soldiers, and thus to leave the finest establishments to abandonment and ruin.-Mollien's Colombia, p. 376. 
cooler portion of mankind to be on the whole a losing pursuit.

It has not been deemed necessary to enter into any inquiry respecting the experiments making by companies formed in England for procuring gold from Brasil. The operations had produced no effect on the period under our consideration. According to the accounts printed in the Quarterly Mining Review, the produce of gold within the last year seems to have been very considerably more than the same districts had previously furnished.

No data present themselves from which to form a judgment either of the proportion of the expenditure to the proceeds, or of the probability of the products increasing or diminishing in future. Dr. Walsh, who visited Brasil in 1829, states that in the first six months of that year the works at Gongo Saco had yielded two thousand and thirtyseven pounds of gold ${ }^{i}$. 'This would amount to between eighty and ninety thousand pounds sterling. The persons employed in those works appear to be one hundred and eighty Englishmen, and six hundred other individuals, chiefly slaves and their families who had been purchased by the association. A few years will probably enable the public as well as the adventurers to determine how far the undertaking is likely to be profitable or

1 Walsh's 'Travels in Brasil, vol. ii. p. 212. 
otherwise. At present, as in all mining undertakings, the expectations of the persons engaged are very sanguine.

It may not be improper to notice a kind of mania on the subject of gold mines, which at present prevails in some part of the United States of America, although it is of too recent a date to have any influence on the subject of this inquiry. As far as it extends, it may be compared with the excitement created in Ireland a few years ago by the discovery of some small portions of gold in the mountains of Wicklow.

Some gold had been found in North Carolina as early as 1824; the amount was then only six thousand dollars; in 1825, it increased to seventeen thousand; in 1826, it rose to twenty thousand; in $182 \%$, to twenty-one thousand; in 1828 , to forty-six thousand; and in 1829, to one hundred and twenty-eight thousand. Besides the attempts made in North Carolina in the year 1829, the same spirit of searching was extended to Virginia, where it obtained two thousand five hundred dollars, and to South Carolina, which yielded three thousand five hundred dollars. This tendency has extended southward to Georgia, where a mine is said to have been discovered near Gainsville, in Hall county. It is called a ridge mine, and the rocks, when pounded, produce gold in a greater or less quantity. "On the 21st September, 1830, seven hands procured two hundred and five penny- 
weights of pure gold, equal to one hundred and eighty dollars; but this appears to have been much more than the average produce of a day's labour ${ }^{1}$."

The whole of the amount of the gold and silver supplied by the late Spanish dominions in America may now be brought under one view thus:

Divisions.

Mexico

Guatimala

Columbia

Peru

Buenos Ayres

Chili
Amount in dollars in twenty years.

$220,043,200$

$2,893,710$

$33,564,267$

$64,688,429$

$30,000,000$

$16,618,880$

$367,808,486$

Or in sterling at $4 s .2 d$. the dollar

$\mathfrak{E} 76,626,768$

To this may be added the produce of Brasil $4,110,000$

Whole produce of America

$\mathfrak{\&} 80,736,768$

In Europe the produce of gold and silver has declined, when the average of the last twenty years is compared with that of the one hundred and ten years which preceded it. This is the case with the Austrian dominions. Up to the year 1773, Hungary and Siebenbürgen yielded the amount of five million florins in gold and silver. After that year it declined to half that sum, and in the

${ }^{1}$ Quarterly Mining Review, No. 5, p. 96. 
last twenty years has scarcely exceeded three millions ${ }^{1}$.

Within the last sixteen years there has been a great increase in the produce of gold and silver from the Russian mines. These are, indeed, in Asia, but as their supply is brought to the mint in Europe, and from thence circulated, it coincides with the plan here adopted to consider their product in the same view with that of America and Europe.

According to a communication from Baron Humboldt, made since his return from Asia, to the editor of "Poffendorf's Annalen," it appears that the annual produce of the precious metals of Europe and of Asiatic Russia amounts to twentyfive thousand five hundred marcs of gold, and two hundred and ninety-two thousand marcs of silver; of which seventy-six thousand five hundred of silver and twenty-two thousand of gold are supplied from the Russian empire ${ }^{2}$. The value of this gold is about seven hundred and twenty thousand pounds, and of the silver five hundred and thirty thousand pounds, being together one million two hundred and fifty thousand pounds annually, or in the period of twenty ${ }^{3}$ years from 1810 to 1829 , twentythree millions; to this the supply from America,

1 Andres Neueste Zahlenstatistik, p. 153.

2 See Appendix, No. 10, for a more particular account of the produce of the Russian mines.

3 Of late the silver in England has increased, chiefly from 
eighty million seven hundred and thirty-six thousand, being added, will make together one hundred and three million seven hundred and thirty-six thousand pounds; but as the mines of Russia in the early part of the period were less productive than towards the end of it, we may make an allowance of the three millions seven hundred and thirty-six thousand pounds for that circumstance, and take the whole amount as one hundred millions, or five millions annually.

that found in the lead in some of the northern mines. It is said to have amounted to as much as one hundred and eighty thousand pounds in value. On the whole term here considered, the amount here is but small, and it affects the calculation of Humboldt in too slight a degree to make any alteration necessary in the estimate he has formed. 


\section{CHAPTER XXVI.}

On the consumption of gold and silver in the twenty years between 1810 and 1819, but especially on the application of them to other purposes than coin.

IT might have been supposed that as approaches are made to recent times, there would have been less difficulty in arriving at some approximation to the quantity of the precious metals that is annually withdrawn from the circulating medium, or that is intercepted in its progress from the mines before it has been converted into coin. There are some facts that can be more accurately ascertained, and many calculations which may be framed with more confidence, but still the field is so large and the certain data so few compared with those that are more or less doubtful, that the inquirer, after the most assiduous attention, and the most rigid examination, will admit his own conclusions with hesitation, and be too diffident to feel a very strong desire to persuade others to adopt his views.

In the vast field that lies before us, it is necessary to select that part which can be most easily and most accurately examined, and therefore the state of our own country will receive the first consideration. The greater part of the application both of gold 
and silver to other purposes than the fabrication of money takes place in London; but in Birmingham much gold and some silver are annually applied to various ornamental purposes. In Sheffield there is much use of silver, chiefly for plating. In Liverpool and Chester many watches and some jewellery are produced, and those articles which are liable to the duty are assayed at the latter place. At Derby there are several manufacturers of jewellery and gold articles, who produce goods of a quality superior in the fineness of the metal to those made commonly in Birmingham, but perhaps inferior to the best London jewellery. At Newcastle, York, and Exeter, are manufactures of gold and silver goods, and of jewellery. In Scotland and in Ireland ${ }^{1}$ the goods they make, which are not liable to duty, bear probably the same proportion to those chargeable with it, as is found in the manufacturing towns in England.

There are few towns in this kingdom where there are not to be found some gold and silversmiths, who use greater or less quantities of the two metals. Plain gold rings, and gold chains from wire of appropriate size, are commonly made by such workmen, and though the quantity by each individual is small, yet the consumption of the whole number must be of considerable though unknown amount.

${ }^{1}$ See Appendix, No. 13. 
It would have been impossible to have obtained from so many and such various quarters, whatever pains may have been taken, exact returns. It was . therefore thought proper to limit the personal examination to the three principal places, London, Birmingham, and Sheffield. In the author's inquiries among the persons connected with the several branches of the trades that use gold and silver in those three places, he has found so much readiness to communicate information, so much accuracy generally in the accounts rendered by some, verified by similar accounts supplied by other individuals, and so much desire to point out other sources of information, that he looks back to the time spent among those persons with much satisfaction.

In each branch of the trade a certain number of persons were so kind as to furnish exact accounts of their own consumption of both gold and silver, and their opinions as to the quantities consumed by others in the same branch. By this a clue was furnished, when these several accounts were compared with each other, which led to calculations that approximated as near to accuracy as could be expected in such an inquiry.

In some cases the trade of a refiner of gold and silver is combined with another technically distinguished by the name of Sweep-washers. The persons employed in this branch purchase whatever refuse is obtained from the floors of the various 
descriptions of workshops in which the divisions and subdivisions of the trade in gold and silver are carried on. These sweepings, as they are termed, are first by stamping crushed into a minute dust. The mass is then amalgamated with mercury, which takes up the precious metals. This composition afterwards undergoes a kind of distillation, in the course of which the mercury is evaporated by heat, is then condensed and preserved, and the precious metal parted for future application to the purposes for which it is needed.

In pursuing our inquiry, the first step appeared to be to ascertain the quantity of gold which is annually produced by the whole of the refiners and sweep-washers. Whatever that quantity might be found to be, as the whole is applied to manufacturing purposes, it would be a guide to the knowledge of the remainder. There are certain branches of trade in which refined or pure gold alone is used. The gold-beaters, the water-gilders, the gold lace makers, the china-gilders, the gilders of buttons, and of toys, and trinkets, use only fine gold, or gold with such minute particles of alloy in it as are necessary to make it adhesive.

The jewellers, too, who are the great consumers of gold, use partly refined gold, or at least a considerable number of the trade do so. The case, however, of that business will be presently considered more at large.

VOL. II. 
As the reports of the quantity of the gold which the refiners and sweep-washers furnished to the several branches of the manufacturers of gold articles were very discordant, and varied according to the persons who supplied them, in the proportion of one to four, or even one to five, and as all farther calculations must in some measure depend on the degree of correctness which could be obtained on that first step, it appeared necessary to attend to it most scrupulously.

The business of a refiner requires a large capital. From the high value of the smallest particles of their commodity, a minute attention to every detail is indispensable. It is impossible to conduct the delicate operations on which they are engaged without some considerable knowledge of the chemistry of metallic substances, which is, in many instances, extended far beyond the bounds of their own trade. Traders of this description are open and accurate in their communications with those from whom they fear no rivalry, and suspect no improper or underhand intention; and, except in one instance, every individual applied to frankly stated his own product of refined gold, and gave his opinion of the product of other houses with whose transactions he had any means of being acquainted. Out of twentythree or twenty-four houses in the country and in London in these branches of trade, eleven 
supplied to this inquiry the real quantity of gold, which, on the average of the last years, they had refined. This was done under an assurance of secrecy as to each individual, but with full permission to state the collective result in any manner that might be deemed advisable. A small number of these houses refine more than thirteen thousand ounces yearly, most of the remainder from six to eight thousand five hundred; and the produce of the whole eleven amounts to one hundred and eight thousand five hundred ounces. There are twelve or thirteen others, of which three may be calculated to refine about four thousand five hundred ounces each, four about three thousand five hundred each, and the remaining four about two thousand five hundred each. The whole may be brought under one view, thus :-

\begin{tabular}{cr} 
Product of pure gold from eleven houses & $\begin{array}{r}\text { Ounces. } \\
108,500 \\
\text { three houses }\end{array}$ \\
four houses & 13,500 \\
four houses & 14,000 \\
& 10,000 \\
\hline & 146,000
\end{tabular}

From the time that has been spent in this branch of the inquiry, from the number of persons from whom communications have been received, and from the consideration which has been since paid 
to all the circumstances connected with the subject, the degree of confidence given to the result arrived at is greater than can safely be bestowed on the future stages of the examination.

The mode in which these hundred and fortysix thousand ounces of pure gold are disposed of among the several manufacturers becomes now a topic for consideration. The several modes have been attentively inquired into among the chief persons employed in the several seats of the manufactures in this kingdom, and on a great part of them the information obtained has been tolerably definite.

The various branches of gilding cause a great annual consumption of the finest gold, or of gold with such minute proportions of alloy as do not lessen its value more than one per cent., it being not more than two or three grains in the ounce.

The gold-beater's trade is chiefly carried on in London; to an inferior extent in Birmingham, Dublin, Glasgow, Edinburgh, Liverpool, and some other places. The numbers of this branch are about eighty in London, and twelve or fourteen in the other places. One of the largest makers of leaf gold stated his weekly use of that metal to be twenty ounces; another, who may be considered a medium manufacturer, showed by a reference to his accounts, which were kept with apparent regularity, that he had used sixteen 
ounces and a quarter weekly; several were conversed with who did not use, weekly, more than three or four ounces, and some who worked up still less, and that chiefly by their own family, with the help of one or two apprentices. It cannot be very incorrect, considering that the greater numbers engaged in this branch of trade are of a class that scarcely earn more than the wages of a good journeyman, if we estimate the average rate of the whole ninety gold-beaters at three ounces weekly. A corroboration of this estimate has been obtained by calculating the rate of wages, and comparing it with a given quantity of gold.

The leaf gold, when finished, is placed between paper, in leaves of three and three-eighth inches square, twenty-five of which form a book. These books are sold by the thousand, at various prices, according to the thickness of the leaves. It was found that eight pennyweights of gold could be converted into a thousand books of the cheapest, that is the thinnest, kind. The cost of the gold, at eighty-seven shillings per ounce, amounted to twenty-nine shillings; the cost of the labour on it amounted to twenty-three shillings; and the thousand books thus produced were sold at two pounds fifteen shillings, thus leaving an apparent profit of no more than three shillings to the manufacturer. He derives another and, perhaps, his chief profit from the portions of gold that are 
saved as clippings, in reducing the leaves to the proper form and extent. In beating the gold, it is by repeated operations with the hammer brought to the required thin state; but it is in large leaves, of an irregular shape, and these, when reduced to the prescribed form and size, necessarily leave much clippings, all of which are carefully preserved for future application, and contribute some addition, perhaps ten per cent., to the gains of the manufacturer.

The account here given of the gold-beater's operations applies more especially to the trade as carried on at Birmingham, where the chief leaf gold is of the thinnest kind, and in which, consequently, the wages bear the highest proportion to the value of the gold. In London, though some little leaf gold is made, chiefly for the use of painters, as low as three pounds ten shillings the thousand books, the greater part is of a thickness which makes it worth from four pounds to four pounds ten shillings, and from that price upwards, to as high as nine pounds. It thus appears that the proportion of the wages to the gold varies excessively; in the thinnest leaves amounting to more than two-fifths, and in the thickest, which requires less hammering, to less than one-tenth.

This disquisition may appear too minute, and may, perhaps, be tiresome to the reader, but it 
was made among other inquiries, to verify the calculation, framed in another way, on the quantity of gold used by the gold-beaters. Having ascertained the number of hands, the rate of wages earned, and the weight of gold weekly used, in a particular shop, and then learning the number of workmen in the other similar shops, an estimation was made which came sufficiently near to that produced by the relations of the several persons conversant in that branch of business to satisfy the inquirer that his view could not be far removed from the truth.

We arrive thus at a conclusion that the annual consumption of all the gold-beaters in the British kingdom is about seventeen thousand five hundred ounces of fine gold.

Another description of gilding requires annually a great portion of pure gold. This trade is sometimes distinguished by the name of water-gilding, and a considerable branch of it by that of toy or button-gilding. The gold in the form of dust or fine powder is mingled with quicksilver, and, in a consistency like paste, is applied to the metals that are to be gilt. The mercury causes the gold to adhere to the other metals, when by the application of heat it is evaporated, and leaves the gold on the surface of the object. The application of gold in this way may be distinguished by the two principal branches of the manufactures in 
which it is used. The trade in gilt buttons is chiefly carried on in Birmingham, but extensively also in London. In the first town there are upwards of fifty large, and many small establishments; in the latter a much smaller number, but these are calculated to expend about three times the quantity of gold on the same number of buttons. From the influence of fashion within the three or four last years the number of gilt buttons fabricated has somewhat declined, though the whole produce is still very large. Many of those for the use of the officers of the navy and army and other gentlemen are made at Birmingham, as are those destined for foreign markets, whilst the trade in London supplies a portion of them to the higher classes, and has an almost exclusive monopoly of such livery buttons as have arms or crests stamped on them.

Communications received from ten of the largest manufacturers in Birmingham led to the conclusion that their weekly consumption of fine gold had till within the last three years amounted to two hundred ounces weekly, and that the several smaller houses, from their greater number, might use about three hundred ounces. Within the last three years the demand has declined, and the consumption of gold is estimated not to exceed three hundred and sixty ounces. The quantity used in London is not supposed to amount to 
more than one-sixth of that which Birmingham consumes, and on these grounds we are led to the conclusion that the whole trade in gilt buttons has, during the last twenty years, required a supply of gold of about six hundred and fifty ounces weekly, or about twenty-one thousand eight hundred ounces yearly.

A larger portion of gold is used by the manufacturers of gilt toys, a branch of trade which is followed in more than one hundred establishments in Birmingham, and several in London. The vast quantity of wares of this description, of which almost every part of the world receives a supply from England, would require an enumeration of all the personal and domestic ornaments and utensils that are known, whose value singly may be very minute, but when the whole mass is included, comprehends a great amount.

The gilding of these toys and trinkets is in part executed by the makers of them, but a very large part of such goods is formed by one class, and afterwards sent to another branch of trade called gilders, who execute only that part of the work. Among those who gild their own goods it was found, in individual instances, that several had used from six to ten ounces of gold weekly; that others, and those the most numerous body, used from three to four ounces weekly. With those who gild the goods of other people the con- 
sumption of gold is much larger; in one case it was found to have been from twenty to thirty ounces, and in some others from fifteen to twenty ounces. It was impracticable to visit and collect accurate returns from a number of tradesmen, amounting, in the two classes here treated of, to more than one hundred and fifty in Birmingham alone, besides some in London. It was deemed sufficient to see some of the most respectable and intelligent, and from their accounts to frame the most probable average of the whole. In this way, and considering that, especially in London, a large portion of silver goods is gilded, either internally or wholly, we have been induced to calculate the weekly consumption of gold in the gilding of the description here noticed at six hundred ounces weekly, or at thirty-one thousand two hundred ounces annually.

The plating of gold, which will be further noticed when the subject of jewellery is under consideration, is supposed, by those well acquainted with the trade, to employ about fifty ounces of fine gold weekly, or two thousand six hundred ounces yearly.

The use of gold in the potteries has very much increased of late years, as must be obvious to any person of observation who notices how profusely it is applied to tea, to table, and to ornamental china. From the great number of the manu- 
factures of that commodity, and from their not being very much concentrated-for though they abound most in Staffordshire and Shropshire, there are large establishments at Worcester, Derby, in Yorkshire, and other parts of the kingdom-it has been difficult to make such particular inquiries as have been directed to other branches of trade. From the imperfect view we have been enabled to take, and from the opinion we have obtained from some of the larger dealers in china ware, we feel disposed to consider the whole consumption to be about one hundred ounces weekly, or five thousand two hundred ounces annually.

The china manufacturers use only the fine gold; some is supplied to them by the refiners of Birmingham and Sheffield, but the larger part probably from those of London. It has been stated that some of the manufactures have bought as much as twelve or fourteen ounces a week, but it could not be clearly shown that such was the regular demand, or taking the number of them into calculation the estimate would be much greater than is here assumed. In this state of great uncertainty, it has appeared more proper to take the opinion of those most conversant in the trade than to adopt any estimate on imperfect materials. We have now arrived at the end of the calculation of that portion of refined gold which is applied to all the purposes of manufacturing, except to that in 
which the far largest proportion is annually consumed-the fabrication of those elegant ornaments collectively, denominated jewellery.

According to the best information that could, from the nature of the case, be obtained, we have arrived at a conclusion that, of the gold rendered pure by refining in the kingdom, amounting to one hundred and fifty-six thousand ounces annually, the application of it in the various ways that have been examined amounts to about eighty-eight thousand ounces, leaving nearly sixty thousand ounces yet to be accounted for.

It may be here remarked that with the exception of that gold which is used by the goldbeaters, the whole of the portions we have noticed may be said to be not merely applied but absolutely consumed. Of the best gold it is supposed onefifth may be again recovered by the burning of picture frames and such other substances, except the metals and the pottery, upon which the leaves have been laid.

The application of gold to jewellery must now be - considered, in the course of which it will be seen, that the quantity so appropriated very far exceeds in amount all the other modes in which that valuable substance is made use of.

Without being minute observers of fashion, or without being constant frequenters of those circles in which its changes are most observable, it is 
impossible not to remark how great, though gradual, has been the increased introduction of gold ornaments in the decorations of females. This has been especially remarkable within the whole of the last twenty years, but perhaps much more so within the last, than the first ten years of the period.

Only a junta of jewellers, dressmakers, and ladies'-maids could give a complete catalogue of the numerous ornaments of gold and silver which have of late been added to the dress of our females in the higher circles of society. Ornaments for the head, including large combs of gold, necklaces and broaches of extended size, clasps and buttons of gold to fasten the bodies of the gowns, bracelets and armlets, additionally numerous rings on the fingers, gold hooks and eyes for the drapery of the gowns, eye-glasses set in gold and secured by chains of gold, and a watch with gold seals, and trinkets too numerous to be mentioned by one not professionally a master of dress. Such are the additions recently made to the application of gold to purposes of ornament.

Whatever effect may be produced by such fashionable changes when confined to the higher classes, it is not bounded by their consumption alone. The ornaments of this kind are first fabricated of fine gold, and commonly in London alone. They are, however, soon imitated by other workmen in gold of inferior quality, in some de- 
gree of inferior workmanship, at Derby and Liverpool, but more especially at Birmingham. At the latter place much gold is so mixed with alloys, in the combination of which much chemical knowledge is applied, that it can be sold at all prices from a half to even a quarter the cost of standard gold. From metal of these several degrees of fineness ornaments are made which enable the more numerous class, a little below the fashionable world, to rival their superiors in fashion, and with no danger of their inferiority being detected except by the very small number who are critical judges of the metals.

Another step has been made in the progress of suiting ornaments to the finances of a still more numerous class of lovers of dress. Of late years the practice of plating with gold in a manner similar to that long practised with silver has been introduced. A thin plate of gold is fixed on a thicker one of inferior metal, and then by means of the powerful flatting-mills the substance is extended to the space desired, and presents a sheet on one side of thin gold and on the other of inferior metal. From this metal thus compounded great numbers of seals and other small articles are made which are gold to appearance, and will retain that appearance even when constantly worn during ten or twelve years.

The gilding of metal, by applying to it powder gold combined with quicksilver so as to leave 
only the gold on the surface, is another mode by which toys and trinkets are furnish $d$ at a cheap rate to those whose purses do not admit of their buying ornaments of either fine gold, alloyed gold, or gold plating. These are the millions in every part of the world, each of whom obtains and disperses a certain quantity of gold which, though minute individually, amounts to a sum of high value when the whole of the human race who consume such articles is comprehended in the calculation.

If among the male part of the public the use of gold ornaments has not been adopted to the same additional extent as among the females, yet some progressive increase is very apparent. 'The use of gold chains for eye-glasses, the increased number and size of seals, broaches, and breast-pins, and the small waistcoat buttons of gold, or of gilding or plating, have caused a great consumption of that metal. Whoever has travelled much on the continent must have been struck particularly with the size of the seals, the great number of trinkets, and the weight of the gold chains usually appended to the watches both of the ladies and gentlemen. The fashions of Europe extend their influence to every civilized part of the world. In America, in the different colonial establishments founded by Europeans in the West Indies, in Africa, Asia, and Australia, besides their domestic manufactures, they are supplied with ornaments consisting in a 
greater or less degree of gold and silver, some portions of which are again used by even the savage tribes which are in contact with them.

From this extensive spread of ornamental as well as of useful articles, it must be obvious that no calculation, with whatever care or research it may have been preceded, can be of such a nature as to be more than an approximation to accuracy. The task, however, must be undertaken, and the reader be left to give that credit to the result that shall be presented to him which in his judgment it may merit.

As the only fields of minute investigation at hand on the subject of the trade of the jewellers were London and Birmingham, what refers to that trade in the following pages is chiefly confined to those places, though they may, perhaps with justice, be extended to Liverpool, Derby, and the other towns where jewellery is fabricated.

In London the most costly articles of jewellery are devised and completely finished by the same persons; and, exclusive of the precious stones, which in some of the ornamental products are the chief costs, the greatest expenditure on them is the gold. That metal is rarely used in a pure state, though in some of the more delicate parts, such as the filigree work, it is mixed with but a very small portion of alloy. This fine gold is commonly supplied to the jewellers by the refiners, and that worked up by them consists of the fifty-eight thousand ounces 
which, according to the estimate before framed, remains, after the part appropriated to various other purposes has been deducted. It forms, however, but the minor proportion of that used by the jewellers.

The gold used by the first-rate London jewellers is commonly of sixteen carats fine, or with twothirds of its weight pure gold. As that gold which can be purchased consists for the greater part of light guineas, light sovereigns, doubloons, Portugal pieces, and other foreign coin, it may be considered as of twenty-two carats fine, or as two parts in twenty-four, or one twelfth less fine than the refiner's gold. The price of this standard gold is three pounds seventeen shillings and ten-pence halfpenny per ounce, and such gold is always a ready money article. The price of the pure gold of the refiners is four pounds seven shillings and sixpence the ounce, and is sold on credit. The difference of price is thus nine shillings and three halfpence the ounce, whilst the difference in the real quantity of pure gold is one twelfth part of four pounds seven shillings and sixpence, or seven shillings and three-pence halfpenny. The cost of refining and the loss of weight by that operation may be taken at sixpence the ounce. The difference in price, then, between the standard gold and the pure gold will appear to be one shilling and ten-pence more on the latter than the difference in real value. 
It must then be the interest of those jewellers whose capitals are sufficiently large to enable them to buy their gold with ready money to purchase standard rather than fine gold, with the exception of what is required for such delicate parts of the work as can only be executed with fine gold.

In conversing with some of the largest manufacturers of jewellery whose trade consisted chiefly in making what are called heavy articles, such as mourning and wedding rings, snuff-boxes, chains, plain bracelets, and similar ornaments, it was ascertained that they used no refined gold. Two houses especially, whose use of gold weekly exceeds one hundred ounces, asserted that they never purchased any refined gold, but bought old English light guineas and sovereigns, or foreign coin by weight, and lowered the quality to the degree of fineness most applicable to the particular objects for which they were designed. Another informant, who paid the highest amount of duty at Goldsmith's Hall, affirmed that he purchased no refiner's gold; and another, whose trade consisted in making the more delicate as well as the heavy articles, stated that, "on taking an account of the various qualities of gold used in their manufactory during the last four years, it was found that the proportion of fine gold was nearly six-tenths, and of standard gold, consisting of light guineas, ports, and doubloons, fourtenths." 
Among eighteen of the largest manufacturers of jewellery in London, the fact was ascertained, as nearly as such kind of facts can be, that their weekly consumption of standard gold amounted in the whole to one thousand ounces, whilst the fine gold they used did not amount to more than three hundred ounces. This information is certainly very imperfect, when the master manufacturers in that trade, including those on a moderate scale, are more than ten times as numerous, and whilst the smaller manufacturers who work in obscure garrets; or in other lodgings, and use perhaps not more than two or three ounces of gold monthly, are known to be many hundreds. Among this latter numerous description of workmen, some, to whom a short credit is an object, repair to the refiners for their small portions of metal ; whilst those who have a little money beforehand will prefer buying a light guinea, a napoleon, a moidore, or some other foreign piece of money, the weight of which may be best adapted to their finances and the articles on which they are employed.

In calculations of this kind an inquirer should be constantly apprehensive of exaggerated statements and reports; and that feeling has induced us rather to trust to our own collection of facts, imperfect as it may be, than to any opinions or calculations of individuals. The method here adopted has been attempted to be explained, as 
far as can be done without disclosing the names of individuals or manufacturing firms, or without communicating the extent of the dealings of each respectively. The conclusion to which we have come is that in the jewellery manufacture of England, including London, Birmingham, and the other places where gold is used, the consumption of standard gold is four times as much as the weight of that which is used in that manufacture in pure gold as sold to the jewellers by the refiners.

We would then state the actual conversion or application of gold in Great Britain to be

Fine gold used by gilders of the several

kinds, and by platers, 88,000 ounces ;

By jewellers of all

kinds, . . 58,000

146,000 at $4 l .7 s .6 d . \quad £ 638,75000$

Standard gold used

by jewellers, . . 232,000

Gold watches, viz. in London annually $13,820^{1}$, in Birmingham 600 , in all the other places about 300 ; in the whole 14,720 watches, which average two ounces each, being 29,440 ounces, which, being only of 18 carats, may be valued at $3 l .5 s$. per ounce,

$\begin{array}{llllll}3 & 17 & 10 \frac{1}{2} & 902,270 & 0 & 0\end{array}$ 
This amount, considerable as it may appear, falls very far short of the communications of opinion made by several intelligent persons connected with the various branches of the manufacture of gold-that of one gentleman, on account of his extensive practical use of gold, of his habitual accuracy, and his general knowledge, is entitled to attention. A variety of queries were proposed to him on the several branches of the gold trade with which he was conversant, among others the following, viz.- "What quantity of gold is used by the jewellers in such small portions as are not liable to the stamp duties?" The answer in writing was as follows :-

"An amount which at first sight appears incredible, certainly not less than from four hundred and fifty to four hundred and eighty thousand ounces of standard gold, or, in pounds sterling, a sum of about one million nine hundred thousand pounds sterling, but more probably two millions than less.

"It would be inconvenient to give here the process by which that result is obtained, but there are several ways by which it has been tried, and little doubt, if any, exists as to its correctness.

"There are an innumerable number of articles which, from their delicate texture, cannot be assayed and stamped; and others are made of such inferior gold as scarcely to deserve the name of gold; and yet the quantity is so large that a very 
great portion of gold is consumed in the manufacture. Let any one look at the trinkets and the personal ornaments of himself and his family, and he will see what an immense disproportion exists between the stamped and the unstamped gold. The quantity used is certainly not overstated in the first part of this answer."

It will thus appear that the result at which we have arrived is about one hundred thousand ounces less than what is estimated by this intelligent manufacturer to be annually consumed by the jewellers alone, with which branch of the application of it he is most intimately acquainted.

We come now to the consumption of silver in the several manufactures of this country. In those of gold, from the value of the metal and the high duty which is imposed upon it, a very small proportion of that which is used is liable to be charged with the duty; but on silver it would appear probable that the quantity which does pay the duty is nearly equal to that which is not chargeable with it. In articles purporting to be gold there is commonly so much of the inferior metals combined that it cannot legally be considered as gold, and the duty, which is seventeen shillings per ounce, cannot be enforced; but on silver, as the duty is but one shilling and sixpence the ounce, and what is purchased is expected to be of standard purity, almost every article heavier than five pennyweights is carried to the assay officers to be stamped and to pay the 
duty. In fact, very few gold articles, except most mourning and some wedding rings and snuff boxes, pay any duty; but spoons, forks, and other silver goods exceeding five pennyweights, are charged with the tax.

We shall class the consumption of silver in England under four several heads.

The first division is that on which the official returns give the quantity of silver with a degree of exactness that entitles it to the fullest confidence. It appears that the consumption from 1810 to 1829, both years included, amounted in London and in Scotland to twenty-three million fifty-five thousand and eighty-two ounces ${ }^{1}$; in the country places in England, supposing the whole of the duty in them to have been paid on silver, to nine hundred and eleven thousand seven hundred and forty ounces; and in Ireland to one million five hundred and thirty-nine thousand five hundred and seventeen ounces; thus showing the consumption of the united kingdom for the twenty years to have been twenty-five million five hundred and six thousand three hundred and thirty-nine ounces, or at the average annual rate of one million two hundred and seventy-five thousand three hundred and sixteen ounces.

The next division of the use of silver is into that for watches, the cases of which are stamped at 
the assay offices, to determine the fineness of the metal, although they are not subject to any duty. It is seen that the number of watches stamped in London in the same twenty years was two million fifteen thousand four hundred and sixty-one, or one hundred thousand seven hundred and seventythree annually, each being two and a quarter ounces, would give an annual use of two hundred and twenty-six thousand seven hundred and forty ounces. The average number assayed at Birmingham, but chiefly made at Coventry, was about sixty thousand, weighing two ounces each, or one hundred and twenty thousand ounces. In Edinburgh, Glasgow, York, Dublin, Newcastle, Exeter, Sheffield, and Liverpool, those of which last place are assayed at Chester, the number may be taken together at eighty thousand, of two ounces each, or at one hundred and sixty ounces, thus making together five hundred and six thousand seven hundred and forty ounces.

Another mode in which silver is used is that of making plated goods, chiefly manufactured at Birmingham and Sheffield, and in no inconsiderable degree in London. The rolling of silver in contact with the inferior metals is performed by extensive and powerful flatting mills, at each of these three places, but the largest portion as regards extent of surface is executed at Birmingham. The lowest kind of these rolled sheets produced by the Birmingham manufacturers does not contain more 
than between three and four pennyweights of silver to each pound of the inferior metal on which it is plated. Much of this lower plate is sent from Birmingham to Sheffield, and there manufactured into goods, which by its inferior quality when sold, as it frequently is, as Sheffield plate, injures the reputation of the productions of the latter town, and is a subject of complaint with the respectable manufacturers there. .

The Sheffield plate generally contains more than five pennyweights of silver to the pound of copper or other metal, and much of it is plated on both sides; besides which the small beading which surrounds the edges of the plated goods is formed of silver alone, which, though from its weight not chargeable with the duty, yet in the whole manufacture consumes a large portion of silver. The plated substances rolled by the flatting mills in London have commonly more silver applied to the surface. Much of it is used by the platers to form ornaments for coaches and for coach harness. As these ornaments suffer by friction from the frequent cleaning they require, it is necessary to have a much thicker coating of silver than is required for some other purposes. As far as can be ascertained by inquiries of the platers, of the owners of flatting mills, and of the manufacturers of plated goods, we are disposed to estimate the silver used for that particular purpose in Birmingham and Sheffield, including with it that used at Wal- 
sall and its neighbourhood, chiefly for the saddlers' ironmongers, at about seven hundred and fifty thousand ounces annually. That which is for rolling in London, though of much better quality, being far less in quantity, may be safely estimated at one hundred and fifty thousand ounces.

There is another application of silver to which only conjecture can be applied. Many articles are fabricated of that metal below the weight which is amenable to the assay and the duty. Silver thimbles are annually made by hundreds of thousands, all below the accountable weight. Silver chains, either for eye-glasses or for watches, or for any part of the dress, are formed of links, each of which as a single object is below the taxable weight. Pencil cases, necks of smelling bottles, locks to pocket books, to instrument cases, to portfolios, and small portions to the handles of penknives and razors, and other personal and domestic ornaments, when added together must form a large annual amount of silver consumed, but not liable to the stamp tax. The gold-beaters use some large portions of that metal for making leaf silver for gilding. According to the best account we have been able to collect, silver in leaf can scarcely be made thinner than two and a half times the substance of leaf gold; as eight pennyweights of gold will make a thousand books, whilst it requires one ounce of silver to make that number. The use of leaf silver is certainly much less extensive 
than that of leaf gold, but considering the greater weight of each leaf of the same size, perhaps the consumption of one metal in this particular way may be nearly equal to the other. There is another application of silver by an inferior, but numerous class of artisans, denominated washing with silver, but it has been found difficult to obtain any clue to this branch of the trade by which even a conjecture could be formed of its extent.

Taking the opinion of experienced dealers, and considering the observations here stated, we should not be disposed to estimate the quantity of silver annually used in the several ways noticed in the preceding paragraph at less than five hundred thousand ounces.

Our estimate then of the annual quantity of silver applied in the British kingdoms to other purposes than that of coin appears thus:

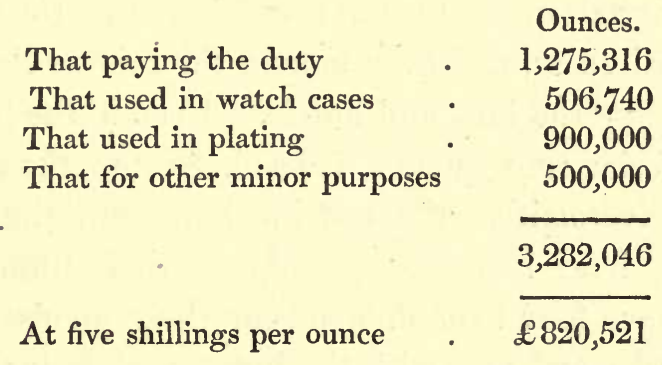

If to this be added the quantity of gold as before detailed at one million six hundred and thirty-six thousand seven hundred pounds, we may consider the two metals as demanding two million four 
hundred and fifty-seven thousand two hundred and twenty-one pounds annually.

The view here taken of the consumption of the precious metals in England receives some corroboration from the best accounts that can be collected from the other parts of Europe. The general peace which prevailed in the greater part of the twenty years here under consideration seems to have had the gradual effects of extending indulgence in articles of ornament and luxury of every kind. This has been so marked that no traveller who has visited the Netherlands, France, Italy, or Germany, at intervals, with a few years between, could have failed to remark the progress, from one date to another, of the greater application of gold and silver to purposes of personal ornaments, and to the higher class of domestic utensils. This has been strikingly obvious in most of the capitals of the several countries, in all the commercial cities, and even anong the middle classes, including the inns and hotels. Even in the towns of inferior consequence, it has been remarked that the silversmiths, the watchmakers, and the jewellers, have increased greatly in their numbers, and have found the demand for their goods keep at least equal pace with the increase of their population.

In France, the portion of gold and silver converted into articles of luxury approaches the nearest to that of England. A person who con- 
templated Paris only, and examined into the state of its various manufactories, might be led to conclude, that the consumption of silver and gold in France was at least equal to that of England. But the chief, almost the exclusive, fabrication of jewellery, watches, clocks, and plate, is concentrated in the capital. Before the revolution there were large establishments for the fabrication of those articles at Lyons, Bordeaux, Marseilles, Strasburg, and some other places. At that time, the number of workmen employed in those branches in Paris and in Lyons alone amounted to seventy thousand; and the portion of the gold and silver used by them was estimated by Necker, in 1789, at about ten million livres annually ${ }^{1}$. But most of those establishments were reduced to ruin by the early political events of the revolution, from the want of internal consumption, from the difficulty of exportation to foreign countries, especially to the great fairs of Frankfort, Leipsic, and other parts of Germany, and from their commerce with the colonies being almost annihilated.

When France exchanged anarchy for a military despotism, security was in some measure restored to property, at least, in the capital; and the plunder of foreign countries, with the taste for

1 See Statistique Générale et Particuliere de la France et de ses Colonies, par P. E. Herbin, vol. ii. p. 180. 
expenditure, introduced by the imperial court and followed by the fortunate generals, restored to Paris a considerable portion of the trade which had previously existed in it, but which had been shared with the places before mentioned.

On the return of the ancient family under whom, and under whom alone, a degree of liberty was enjoyed, and when private property was in security, the manufactures of the several branches of the precious metals partook in a large degree of the general prosperity, and of the universal progress which French industry exhibited.

As early as 1819, within five years of the restoration, according to Chaptal, who had been minister under the republic and the empire, and whose evidence may therefore be viewed as that of an unwilling witness, the number of watches made in France had risen from two hundred thousand in the year 1789 , to upwards of three hundred thousand ${ }^{1}$. According to the statement of this author, the number of gold and silver watches is now equal. The metal in the watches he values at fifty-seven francs for the gold, and six francs for the silver, making the whole amount of the two precious metals appropriated to this branch to be nine million four hundred and fifty thousand francs. Besides these, there were manufactured five thousand pendulums or cabinet

${ }^{1}$ Chaptal de l'Industrie Françoise, vol. ii. p. 162. 
clocks, partly of gold, partly of silver gilt, and partly gilded on inferior metal. Chaptal remarks, that the price of watches has so fallen, and the progress of luxury and the easier circumstancès of the country have so increased, as to extend the use of watches, and the consequent fabrication of them.

It appears by this account that the weight of gold and silver respectively, in the watches made in France, is not more than half the average weight of those made in England. It is rare to see double cases to French watches; whereas in England it is nearly general with those of silver, and very extensively the case with those of gold. Besides this, the English watches with a single case are much more substantially framed than those which are manufactured in France.

Of late years many of the internal parts of the French watches have. been manufactured in the departments, chiefly in the Doubs, the Jura, and the l'Ain. They are sent in an unfinished state to Paris, where the movements are polished and adjusted, and the whole workmanship finally completed.

The labour employed in making the larger articles by the gold and silversmiths in France is stated by Chaptal to be no more than an eighth part of the cost of the precious metal; whilst on the jewellery, the gilding, and the embroidery, " the fabrication of which in Paris is immense, 
the cost of the gold is not more than one-fifth of the price of the finished goods ${ }^{1}$." He adds, "All the statements I have been enabled to obtain, either from my official situation, or from the manufacturers, induces me to conclude that the gold and silversmiths in France employ annually of the two metals to the amount of sixteen millions of francs, and the jewellery appropriates annually to the amount of four millions; of this about three-fifths is used in Paris alone."

According to these representations it is seen, that the watchmakers, goldsmiths, and jewellers together, must apply gold and silver in their several fabrics to the amount of twenty-nine million four hundred and fifty thousand francs, or one million two hundred thousand pounds sterling.

These views of the consumption of gold and silver in France were taken by the ex-minister in the year 1819, when internal security had been scarcely established, and when the foreign trade had assumed no fixed and regular form. Since that year, from all accounts, the trade in each of the branches here noticed had been vastly extended, and a proportionate quantity of the precious metals must have been consumed. The increase had gone on regularly up to the events of July 1830 , when a sudden suspension of this as well as

1 Chaptal, vol. ii. p. 164. 
of almost every other branch of industry occurred; whether the necessary or the accidental accompaniment of those events it would be foreign to the purpose of this inquiry to investigate. $\mathrm{Up}$ to that time, in the last ten of the twenty years under our review, the consumption of gold and silver must have far exceeded that of the first ten ; but, wishing not to exaggerate, we may fairly take the authority of Chaptal as satisfactory evidence, that the annual average did not amount to less than one million two hundred thousand pounds sterling.

As a considerable quantity of gold and silver was known to be consumed in Switzerland in the fabrication of watches, a friendship with a native of that country, a gentleman of great scientific attainments and great accuracy in all statements, gave a fair opportunity of requesting some information on that subject. On his return home from England he favoured the author with the intelligent account contained in the Appendix, No. 11.

Although the use of gold and silver in so small a country as Switzerland can have but little influence on the mass of those substances which the consumption of the whole of Europe demands, yet every statement marked with accuracy assists the estimation which it is necessary to make in those countries, where few facts can be collected, and those only of a general or loose character. 
By the statement of this gentleman it appears that the annual quantity of the two precious metals used in the trade of Geneva and the whole of Switzerland may be taken at the value of about three hundred and fifty thousand pounds sterling, supposing the estimate to refer to gold and silver of the fineness of our standard. There is good reason to believe that this is the case, because it has been asserted by some persons well acquainted with the fact, that the greater portion of the gold is obtained by melting English sovereigns. This is said to be the most advantageous for the manufacturers, because ours is almost the only gold coin on which no charge is made for seniorage.

It would appear extraordinary, not to say suspicious, that a country of such contracted population, and generally so poor as Switzerland, should use so large a proportion of the precious metals; but it is to be recollected that the watchmakers and jewellers of Geneva are competitors, at the fairs of Leipsic, Frankfort on the Maine, Brunswick, and Frankfort on the Oder, with those dealers in the same articles, who attend there from Paris, London, and Birmingham. The number of watches made in Neuchatel is to be accounted for by the relation of that canton with the kingdom of Prussia, in consequence of which, their fabrics are favoured and diffused through its several provinces.

Though watches, jewellery, and plate to a large 
amount are sold at the fairs before noticed, and from thence dispersed through the several divisions of the east and south-east of Europe, yet in each of those divisions there are manufactories for such goods, and some upon a respectable scale. In Bavaria, the silver manufactured in Augsburg is of large amount. In Munich, the capital, there are sixteen goldsmiths and seventeen silversmiths, besides jewellers and watchmakers. Nuremburg has been long celebrated for its gilding; and the gold-beaters there prepare much leaf gold, the quality of which is considered to be superior to any other. In Austria, though the Emperor Joseph the Second induced many French and Swiss watchmakers to establish themselves in Vienna, foreign watches are sold cheaper and more extensively than those of their own manufacture; but in gold and silver plate, the workmen of Vienna combine solidity with elegance, and their articles are more abundantly spread within the empire than any of French or other foreign fabrication. The jewellers of $\mathrm{Vi}$ enna maintain the opinion that their work is superior to any other in Europe. From the general state of ease in which the great body of the inhabitants of those fertile dominions live, from the number of enormously rich nobles, and from the general taste for whatever is ornamental, the application of gold and silver to purposes of utility and of decoration must be very con- 
siderable in the whole extent of the German and Hungarian dominions of the house of Austria, though much of what is so used may not be of domestic fabrication. The countries adjoining to Austria, Poland and Turkey, are, in general, too poor to indulge much in such expensive luxuries as gold and silver; and though in Warsaw, Cracow, and most cities of Turkey, there are jewellers, silversmiths, and watchmakers, their trade is greater in sale of the goods from the German fairs, than from similar articles of their own fabrication. In the Russian empire, though the nobility are disposed to any expenditure which may tend to show and magnificence, yet they bear but a small proportion to the whole population, and many of their estates are encumbered with debts and settlements to an extent which has compelled them to practise unwilling parsimony; and the few who are enabled to indulge in luxuries are more disposed to expend their money on foreign than on domestic plate and jewellery. The chief consumption of the precious metals in the Russian Empire is in the ecclesiastical decorations of their churches, in the sacred utensils dedicated to their church service, but especially on the dresses of the clergy, which are profusely ornamented with gold.

In the Prussian dominions generally, and the same observations will apply to the greater part of the north of Germany, the nobility for the most 
part are far from being in such affluent circumstances as to allow of any great expenditure in articles of luxury. Whoever has been admitted to their hospitable but homely residences, whether in the city or at their country castles, must have remarked the small number and the light weight of the silver spoons, forks, or other articles of plate at their tables, and the paucity of many of those household or personal ornaments and decorations which are to be seen in the dwellings of the middle classes of society in England. There are, indeed, in Berlin several respectable manufacturers of silver goods and jewellery, and some watchmakers; there are others at Dresden, Leipsic, Breslau, Munster, Elberfeld, Aix la Chapelle, and Cologne, and in each of the other cities small workmen; but we are disposed to estimate the consumption of the north of Germany, exclusive of that of Hamburg, Frankfort, and other trading cities, to be less, in proportion to the population, than in Austria, Bavaria, Wirtemburg, Baden, and the southern divisions of that country. In the Hanse towns a great quantity of plate is manufactured, and great display made of every article of luxury which can ornament the persons or the dwellings of the prosperous merchants and others. These, however, bear but a small proportion to the individuals of the countries surrounding them, from the supply of whose wants, and from the 
dispersing of whose productions, they extract their wealth.

The Scandinavian kingdoms, Denmark, Sweden, and Norway, are too poor and too homely to need or to use much of either silver or gold, but what they do use is chiefly fabricated in their respective capitals, or some little is supplied from England or France direct, or through the cities of Lubec and Hamburg.

In the kingdom of the Netherlands, though from recent events no longer distinguished by that name, the use of gold and silver during the period here adverted to was perhaps greater, in proportion to the population, than in any other part of Europe. 'In the northern part of that kingdom especially, the personal ornaments of gold and silver descended to a lower class, chiefly of females, than elsewhere. Large plates of those metals fitted to the shape of the upper part of the head were a remarkable part of dress in the provinces of Overyssel, Utrecht, and Dreuthe; and necklaces, finger rings, and earrings, were to be seen in great profusion and of unusual size and weight. The richer inhabitants were proportionably supplied with the personal and domestic ornaments appropriate to their respective ranks in society. Although, from the habitual economy of the nation, there was perhaps less positive waste than in other countries, and perhaps much fewer 
changes of fashion, yet there was sufficient of both to afford good occupation to numerous goldsmiths, watchmakers, and jewellers, in Amsterdam, Rotterdam, Haerlem, and Utrecht. In the Belgian Netherlands, too, since its junction with Holland, there was a general appearance of ease among the inhabitants, and a most manifest rapid increase of general prosperity under which the use of gold and silver utensils and decorations had been extensively diffused. It is as needless to speak of the misery produced by the reverse that has taken place in the condition of those states, as it is to speculate on what will be their future lot.

In the southern kingdoms of Spain and Portugal there has recently been but a small portion of the precious metals in any other form than that of coin. Much of the silver and gold which the several religious establishments in those countries possessed, and it was probably the largest portion, had been seized during the calamities which the invasion and the civil commotions had inflicted on them. How far the subsequent intervals of tranquillity had restored a portion of what had been confiscated, it is difficult to ascertain. In the several states of the Italian peninsula there is so much poverty among the great mass of the population, that we cannot estimate the use of the precious metals at a high rate. It is true there is a tendency to mag- 
nificence among the higher classes, but they in general have not the means of indulging their taste, except for the fine arts, in which the Italians seem to excel other nations as much as they fall short of them in what may properly be distinguished as manufactures. 'The gold chains of Venice have been long celebrated; and the occupation of the jewellers and goldsmiths of Milan, Turin, Florence, and Rome, produce ornamental objects, some few of which may rival the productions of similar workmen in Paris, London, and Vienna.

This slight survey of the several countries of Europe, with a view to the estimation of their use of the precious metals, is a very imperfect mode of making such calculation. In the absence, however, of other-guides, it is the only one that can be followed. We have seen in England, France, and Switzerland, where from the few data that have been collected, a conclusion has been arrived at, which, though implicit reliance cannot be placed on it, is at least as near an approximation to truth as the nature of the subject will admit of.

In those countries which contain nearly onefourth part of the inhabitants of Europe, we have deemed it fair to estimate the application of gold and silver to other purposes than that of coin at about four million pounds sterling annually for the last twenty years. These are not only the richest parts of Europe, and on that account 
capable of absorbing a larger portion of those metals, but they are also the great workshops in which are fabricated many of those luxurious ornaments and utensils which are furnished to the gratifications of the richer inhabitants of other countries, of countries where the few ornaments of the numerous less rich individuals are supplied by small internal manufacturers. If it be taken into consideration that the small portions of gold and silver which the inferior classes make use of must, from their vastly greater numbers, exceed that used by the rich, it will not be deemed an unfair assumption to calculate, that the hundred and sixty millions of persons in the rest of Europe annually consume two-fifths as much as the fifty or sixty millions who inhabit England, France, and Switzerland. At this rate we shall consider the whole application of the precious metals to ornamental and luxurious purposes to be as follows:-

Great Britain

France

$£ 2,457,221$

Switzerland

Estimated amount for the whole of the rest of Europe being two-fifths

$1,605,490$

thus making $£ 5,612,711$

To this must be added the consumption of the United States of North America, of the newly created states in Spanish and Portuguese America, 
and the colonies still left to Europeans in the western world. The jewellery and plate in those countries were commonly supplied from Europe, and France and England had the largest share of the trade. Of late years, in the United States, there has been a considerable progress made in even the more delicate kinds of manufacture. Since the enactment of the new tariff, which imposed a heavy tax on the importation of jewellery, the manufacture of it has much increased. During the inquiry among the jewellers in London and Birmingham, it was ascertained that many of the workmen in the several branches had been induced, by offers of high wages, with security for the continuance of them, to emigrate to New York, Philadelphia, and Boston. From the great number of families in that country, who are in easy circumstances, and who have a taste for the comforts and conveniences of life, we should estimate the demand for gold and silver at a higher rate, according to the free population, than that assumed as the consumption of Europe; but on the other hand it is to be considered that during a part of the period in question the greater portion of the demand was satisfied from the workshops of the several European states. Under these circumstances we may venture to estimate the quantity of the precious metals used in the United States at about one-twentieth of that consumed in Europe. What is consumed in Canada, Nova Scotia, and the Bri- 
tish West Indies, is probably drawn from England, that of the French colonies from France, and a large portion of that of Brazil and of the Spanish states from the different European countries that trade with them.

We cannot then make any material error by adding to the consumption of gold and silver onetwentieth part for that of America, or two hundred and eighty thousand six hundred and thirty pounds, thus making the whole amount to be five million eight hundred and ninety-three thousand two hundred and forty pounds annually.

A portion of the gold and silver here referred to is undoubtedly supplied from old and broken ornaments, from plate become unfashionable, from the burning of gold and silver lace and pictureframes, and from the sweepings of the shops of the refiners, the jewellers, the goldsmiths, gilders, and watch-case-makers.

According to the information collected from the most considerable refiners, who are commonly the purchasers of broken pieces of gold and silver, of burnt lace and picture-frames, and of foreign gold and silver coins, the quantity of old metal used in their trade is very small when compared with that which is in ingots made from coin either of Spanish, Portuguese, East Indian, or European fabrication, all of which are easily distinguishable by those in the trade. We have been assured by one very accurate person who has superintended the purchases 
of gold and silver in one of the first houses in the trade during more than thirty years, that not onehundredth part of what passes through their scales consisted of gold and silver that had before been manufactured. Similar assertions have been made by all others who have been questioned on the particular topic. We cannot, therefore, deem these meltings of old gold and silver goods to have contributed more than a fortieth part to the precious metals that have been applied to useful or ornamental purposes during the last twenty years. In making, then, such a deduction on that account, we venture to estimate the whole quantity of the precious metals taken from the general stock of them, and destined to purposes of ornamental and useful gratification, to amount annually to the sum of five million eight hundred and ninety-three thousand two hundred and forty-one pounds.

In the former parts of this inquiry, in all the recent divisions of the subject, a large and rather doubtful allowance has been made for that portion of the precious metals which passed to the several parts of Asia by the channels which Humboldt has traced. A great change has been effected in the commerce of the East within a few late years, owing to circumstances which it is not within the design of this inquiry to do more than notice, as' far as they are connected with the subject of the demand for the precious metals. That demand appears to have lessened within the last twenty 
years, and though large quantities have been transported there in some years, other quantities have been again returned to Europe, not, indeed, of the same species of metal, nor in equal quantities. Silver has been conveyed to Asia, and gold has been exported from thence.

The account in the Appendix, No. 14, shows the value of the imports and exports of gold and silver into the dominions of the East India company and into China both by the company and the Americans. As far as it goes, being drawn from the official sources at the India House, its accuracy may be implicitly relied upon; but there are some omissions which must be supplied from calculation, or rather from conjecture. In the account is not included the treasure which was carried by the Americans to any part of Asia except China. It is well known that in some of the years their trade to the English settlements, to the islands in the eastern Archipelago, and to other parts of India, was extensive. After the peace of 1815 some of the other nations of Europe, the French, Dutch, Danes, and Swedes, formed commercial expeditions to India and China; and though we have no specific returns, it may be safely assumed, from their supplying few goods which those countries needed, that they must have carried the precious metals with which to purchase their cargoes. 
Theaccount in the Appendix is made in current rupees, which, though occasionally varying in value, may be taken in the whole term as worth two shillings sterling each. The excess of the imports of gold and silver into India and China by the Company and the Americans in the term amounted to twenty-eight million nine hundred and twenty-eight thousand seven hundred and eleven pounds. In the year 1820-21 the treasure carried by the Americans to China is not inserted, and as their trade was as great in that as in the years immediately before and after, we assume that it amounted to one million one hundred and seventy-one thousand two hundred and eightynine pounds sterling, thus making the imports of treasure thirty millions, or one million five hundred thousand pounds annually during the twenty years.

An exciting effect must have been produced on the continental states of Europe by the return of peace after a long period, in which they had been precluded from any direct intercourse with India and China. They had been long indulging in complaints at their exclusion from that intercourse, their imaginations had formed high expectations of its benefits, and they were eager to commence operations to secure some of those benefits. Neither their soil nor their industry furnished equivalents for the productions of Asia, 
and they must of necessity have transmitted much of the precious metals to make their purchases of Asiatic commodities.

Under a review of all the circumstances, it may be a fair assumption to calculate that the portion of the precious metals exported to India and China by the Cape of Good Hope, which is not included in the account in the Appendix, No. 14, amounted to one-third of what is shown by that account, or about five hundred thousand pounds sterling annually during the twenty years. This will make the whole supply furnished to Asia in that direction amount to forty millions, or at the average rate of two millions yearly. This is about half the sum which Humboldt had estimated for the supplies of the same countries, when he wrote his work on Mexico, now almost thirty years ago.

Humboldt calculated that silver to nearly the amount of four million dollars passed annually from Europe to China, through the Russian provinces on the Caspian Sea, and by the way of Kiachta and Tobolsk in Siberia. It is likely that so industrious an author would make due examination before he published such a statement; but though it may have been correct then, yet thirty years have made a great alteration, and the balance of trade is become so much in favour of Europe, as will be seen in the Appendix, No. 15, that instead of Russia having any necessity to 
convey silver to the eastward, she now receives it from that part of the globe. Thus it is seen, " that in the year 1829, there were received at Petropaulousk from China two thousand four hundred and sixty ounces of silver, and in $\mathbf{1 8 3 0}$ three thousand five hundred and seventy-eight ounces. At Semipalatinsk there were received eighty-three thousand seven hundred ounces in 1829, and in 18.30 eighty-nine thousand six hundred and forty ounces." We see, also, that " the Boukhares and the Taschkenes had brought to Irbit, in the last year, ninety-four thousand five hundred ounces ${ }^{1}$."

It is seen by the translations in the Appendix, No. 15, that the importations and exportations on the extreme eastern frontier of Russia nearly balanced each other, so that there could be little necessity for the transmission of the precious metals, but that little has been in favour of Russia. It is, however, different with that branch of the trade which passes through Teflis, where the imports of the last two years have exceeded the exports. This may have caused the transmission of some gold or silver. The amount of this appears to be but small, and if not quite equalled by what must have flowed in a contrary direction by way of Siberia, cannot be very far short of it.

1 See Appendix, No. 15. 
The trade with the Levant, by which thirty years ago, according to Humboldt, gold and silver to the amount of four million dollars were annually transferred from Europe to Asia, has been so changed that it is a matter of doubt on which side the balance of payments is to be considered. The value of the silk, of the opium, and of the other drugs, which are furnished by Asia, as far as the trade of Constantinople and of Smyrna extends, is more than equalled by the value of the goods sent to those markets from Europe. This has especially been the case since the vast extension of the various kinds of English cotton goods has in some measure supplanted the use of Indian articles of that description in the Turkish dominions.

We therefore see no necessity for considering the whole trade of Asia, taken collectively, to have absorbed more of the stock of the precious metals which Europe had collected from the mines of America, and from those within her own limits, than to the amount of two millions sterling annually, within the twenty years we have been reviewing.

We have estimated the stock of the coin in existence at the end of the year 1809 to have been three hundred and eighty million pounds; and the additions made to it between that period and the end of the year 1829, at the rate of five million one hundred and eighty-six thousand eight hundred pounds annually, would make it one hun- 
dred and three million seven hundred and thirtysix thousand pounds.

From the $380,000,000$ of coin left in 1809 , we deduct for loss by abrasion at the rate of one part in four hundred and twenty in each year, which in the twenty years would amount to $£ 18,095,220$, thus leaving in 1829

$£ 361,904,780$ to which may be added the supply from the

mines

$103,736,000$

thus showing

$£ 465,640,780$

from which must be de-

ducted that converted

into utensils and orna-

ments . . $\quad £ 5,612,611$

and that transferred to

Asia . . $2,000,000$

$£ 7,612,611$ annually.

Or in the twenty years

$152,252,220$

This would show the estimated amount at the end of 1829 to be . $\quad . \quad$. $\quad £ 313,388,560$ Or less than at the end of $1809 \quad$. $66,611,440$ Or a diminution of nearly one-sixth part in the twenty years.

During the period we have been considering, and indeed for many years before, the comparative value of gold to silver had scarcely experienced any alteration. According to the view here taken, the amount of gold applied to purposes of luxury had far exceeded that of silver, perhaps in the proportion of four to one ; but, on the other hand, the treasure transferred to India and China had consisted chiefly of silver, and much more gold 
had been brought to Europe from those countries than had been conveyed to them. It has before, in the twenty-fifth chapter of this inquiry, been attempted to be shown that the durability of gold in coin is in the proportion of four to one greater than that of silver. It has, too, been shown that the recently increased produce of the mines of Russia has consisted chiefly of gold. These circumstances, on which our limits do not admit of enlargement, might be shown to be sufficient to account for the equable rate of value which has been preserved between the two metals during a long period. 


\section{CHAPTER XXVII.}

On the gold and silver of Africa and Asia.

Attention in this inquiry has been hitherto directed almost exclusively during the few last centuries to the gold and silver of Europe and America. These two quarters of the world have been so closely connected with each other since the discovery of the latter, and the intercourse has been so incessant, that as far as relates to our particular subject they may very aptly be considered in a common view. The case is different both with Africa and Asia. 'The first of those quarters is in too low a state of civilization to hold much other intercourse than that which arises from the sale of human beings; which, as we have seen, was the first step towards commerce in the earlier ages of the world. Asia is far more advanced in civilization, and the different countries that compose it have abundant intercourse of a commercial nature with each other; an intercourse which, excepting in the case of China, is much greater than that which it maintains with Europe, America, and Africa together.

Africa. The gold that has reached Europe from Africa has consisted of small grains, stated to have been 
collected from the streams, and carried about in quills as an article of traffic. In Morocco there are reports that gold and silver mines were formerly worked by the Portuguese in the province. of Susa, near to Mesa, and similar reports have been circulated of the province of Bambouk, near Senegal ; but in both cases the operation of obtaining it is said to have required such application of human labour that the employment yielded no profit, and has been long discontinued.

There is no way in which an accurate estimate can be formed of the gold produced in Africa, and the only clue to guide an inquirer are the accounts kept by the late African company, which registered only that brought to England by ships of war. Such ships probably brought the largest portion, both on account of their greater security and lower rate of insurance, and because most of the merchant vessels trading to Africa in their way home first made a passage to the West Indies to procure freight of colonial produce for England.

According to accounts furnished from the records of that company, the whole quantity so imported, from the year 1808 to 1818 , both included, amounted to eighty-one thousand nine hundred and five ounces. Of this, in the seven years of war, from 1808 to 1814 , there were fiftyone thousand five hundred and sixty-nine ounces valued at two hundred and five thousand three 
hundred and forty-four pounds, and in the following four years of peace, thirty thousand five hundred and sixty-nine ounces valued at one hundred and twenty-five thousand three hundred and eighty pounds. As the Dutch and French, after the return of peace, carried on some trade with their settlements on the western coast of Africa, that may account for our annual importations having been somewhat less in the four years of peace than in the preceding seven years of war.

This communication, imperfect as it is, furnishes a strong presumption that the produce of gold from the African washings, the only source from whence that metal is derived, has been commonly much exaggerated. It may also serve to account for the fact, that though some larger payments are made with gold dust, yet those of lesser amount are made in Spanish dollars, (which the lamentable extension of the slave trade has introduced more copiously than at any former period), and the fractional parts in those shells called cowries, which were the former current money of the whole of Africa.

It is well known that in the trade on the coast of Africa neither gold nor silver are made use of as measures of value; but that an ideal standard has been adopted, originating at the period when the Europeans first resorted to that coast. This standard, called a bar, was at first used because the chief commodity in request was bar iron. All 
others were measured by it. Thus a slave, a piece of cloth, or an India baft, was reckoned worth a given number of bars; and even iron itself was, and still is, measured by these imaginary bars. As gold is thus rendered a mere commodity and of less value than it would represent if it performed also the function of money, it will generally and profitably find its way to other countries, where, from being both a commodity and a measure of all others, it acquires a greater worth when exchanged for other objects.

We are therefore disposed to estimate at a very low rate the whole produce of gold from Africa, and as no silver is known. to be extracted from that part of the world, in our estimate of the production and consumption of the world at large we have not thought it necessary to take notice of either the western or eastern shores of that quarter of the world.

The eastern coast of Africa, where the Por- Eastern tuguese still retain some settlements for carrying on the slave trade, may be passed over with a slight notice. According to some of the authors of the sixteenth century, Melinda, Sofala, Mozambique, and other spots on that side of Africa, afforded large portions of gold, but their accountsmust be received with great hesitation. The latest traveller, Mr. Salt, who visited those places in 1809, represents their present supply of gold as very insignificant, and has removed much 
of the delusion which had been spread respecting the ancient produce of that metal. After remarking that the only way by which gold is now procured is by washing the sands of the rivers, he says, " in this manner a considerable quantity is still annually accumulated, though it seems to be rapidly decreasing, for in 1593 the governor of Mozambique, George Menzes, collected for himself and the viceroy of India one hundred thousand crusades, and I do not believe that one third of this amount is now altogether annually produced ${ }^{1}$."

Asia. In taking a review of the produce of gold and silver from Asia, the field is so extensive and the information to be collected so imperfect, that no one, however industrious in his researches, can hope to do more than arrive at some foundation on which to ground an estimate?

Turkey. In Asiatic Turkey few mines are now or have recently been worked. The only district in which silver is procured is that of Urla, in the province

1 See Salt's Voyage to Abyssinia, page 68. The crusades here mentioned were probably the thirty-second part of an ounce of gold, and.equal to about two shillings and sixpence sterling.

2 In making extracts from the various authorities on the subject of Asiatic mining, which were made without any view to publication, the references to the authority were unfortunately omitted, and many of them cannot now be given; but it is believed that the greater part, especially what respects the islands, was taken from the works of Crawford. 
of Erserum. The amount is not known. Every three months a caravan is despatched to Constantinople, consisting of about fifty horses, with the bars of silver. As horses cannot travel in those countries with a greater weight than about one hundred and sixty pounds, that number could not convey more than eight or ten thousand pounds, which, repeated four times, would amount to from one hundred to one hundred and twenty thousand pounds sterling in value. The workmen employed in these mines are, or were, chiefly Greeks ${ }^{1}$. Some silver is found in the lead mines of Argena, but probably to a small extent. No gold is now known to be found in those countries at present subject to Turkey, which, in the remote ages of antiquity, are recorded to have yielded that metal most abundantly.

In Arabia no mines of the precious metals are Arabia and known to exist, and from the great scarcity of Persia. fuel, if any were found, it would probably be unprofitable to work them. In Persia, though in ancient times silver was said to have been produced, none of the precious metals have for many years been sought for, though, from the testimony of an enlightened native of that country, we have recently been assured that it is found in the lead mines combined with that metal, in such quantities as would well repay the capital destined to that 
purpose, if any such could be found and so applied. In Atganistan or Cabul, gold is said to be found in some of the streams that flow from the mountains of Hindoo Cosh, and some silver in the country of the Caffres, but nothing is known as to the quantity of either ${ }^{1}$.

Ava. In Ava, or the Birman Empire, mining seems to be an important source of the national wealth, but no data respecting the quantity of the precious metals thence furnished are attainable. There are said to be mines of silver in the eastern range of mountains towards the Chinese frontier, and, according to report, the rivers, especially the Choe Lien Kioup, or the river of golden sand, yield gold dust.

Assam. Although Assam has been added to the British dominions in India, the junction is too recent to have yet afforded much information respecting the operations in gold washing. The number of persons engaged in that pursuit was said to have amounted to about twelve thousand, and to have produced annually thirty thousand ounces of gold. A mine, called Pakerguri, at the junction of the Bramahaputra river with the Dontriri, is said to be worked for a short time in every year, during which one thousand men are employed, who are paid for their labour in land.

Tibet. Tibet is rich in minerals. Gold is found in

${ }^{1}$ Hamilton's East India Gazetteer, vol. i. p. 10. 
many parts in uncommon purity. The mines are the exclusive property of the government, which permits one of them to be worked by contract to such an extent as shall yield a net amount of about five thousand ounces; and the whole produce is, perhaps, scarcely to be estimated at more than double that amount.

In Cochin China both gold and silver have Cochin been extracted from the sand of the rivers, but, China. according to Bissachere, the working of mines was prohibited under the penalty of death. St. Croix asserts that the gold is of the purest kind that is ever found, but that the quantity yielded is very small.

It does not appear by any accounts that have Nepaul. been collected, that any of the precious metals have been procured in the country of the Nepaulese, or in any part of Tartary, though in very remote ages a large portion of gold, according to history, was extracted from the latter country.

The extensive territories of the East India company afforded little of either gold or silver; none is found within the governments of the three great presidencies. Some gold is procured on the Malabar coast, in Coimbatore, and in the whole tract of country to the west and south-west of the Neelghery mountains. According to the evidence of Mr. Baber before the East India committee of the House of Commons, the auriferous district 
extends over two thousand square miles. It is, however, but slightly worked, and that wholly by slaves belonging to the proprietors of the soil. The individuals who own the land are jealous of the interference of strangers, and are themselves extremely poor; and thus, whatever amount of metallic treasure may exist in the soil, very little of it is brought into circulation ${ }^{1}$. Malay pen- The Malay peninsula, from having been called
insula.

by the ancients Chersonesus aurea, may be presumed to have formerly yielded much gold; but if it produces any at the present time, little or none of it makes its appearance in the trading world, but must be used by the natives as personal ornaments.

China. The notices we have respecting the produce of gold and silver in China are very few, and those by no means definite. It is in general known that in the mountains on the eastern frontier there are mines of silver. In the evidence of Mr. Crawford before the East India committee, it is stated that the province of Sechuen yielded gold, that of Houansi silver, and those of Kiansi, Gunnan, and Koneicheou both these metals ${ }^{2}$. Of the extent to which mining operations are carried, there are no data whatever.

1 See evidence of East India committee, ordered to be printed, April 2, 1830.

${ }^{2}$ Parliamentary Paper, ordered to be printed, March 25, 1830. 
By a recent account, which appears worthy of credit, "the whole revenue of China amounts to eighty-four million ounces of silver. Of this, about thirty-three millions are paid in metal, and about fifty-one millions in grain and other commodities, consumed for the most part by the local administration of the several provinces; a portion only, to the amount of six million ounces, is annually remitted to Pekin ${ }^{1}$."

No money, either of gold or silver, is coined in China. The money in use there is the dollars of Spain or of her late colonies, which, either whole or divided into halves or quarters, are very general on the sea-coast, or sheets of silver rolled thin so as to be easily divided into the portion required for payment. The coined as well as the rolled silver passes by weight, and every trader carries with him scales for weighing, and a touchstone to test the degree of purity of the metal. The only money current in China of native fabrication is a small brass coin, known by the name of the cash, which, though one hundred and fifty of them are only worth one shilling sterling, are well adapted to the use of a country where money is dear, or, what is the same, where all other commodities are cheap, in order to facilitate the exchanges of one description of common articles with others.

In the contraband trade carried on in the out-

1 Bulletin des Sciences, No. 5; May, 1829. 
ports of China by some Europeans, which consists chiefly in supplying the prohibited drug, opium, it is represented that a large portion of a peculiar kind of silver is delivered in payment-it is distinguished by the name of Syce silver, and has been supposed to be exclusively the product of the native mines. A better knowledge has, however, taught us that it is indifferently either Chinese or American, or any other silver which has undergone the process of refining, and made so pure as to contain only two parts of alloy to ninety-eight parts of silver. It has been said that large portions of this silver are smuggled out; but the term large, when applied by an individual illicit trader, may have a very different meaning from what it bears in the language of one who is treating of the whole export of an empire of such extent, and containing so many millions of inhabitants as are to be found in China. We are induced to make this remark from observing that in the year 1828, when the export of silver from China to Calcutta was two million two hundred and forty-four thousand three hundred and twenty dollars, the Syce silver was only nineteen thousand two hundred and ten, and all the rest was either in Spanish dollars, or in ingots of. South American silver ${ }^{1}$. It is known that gold

${ }^{1}$ See the examination of W. S. Davidson, esq., March 3, 1830, and of Robert Rickards, esq., March 22, before the Committee of the House of Commons. 
in China is never used to perform the function of money, but is bought and sold exactly like pearls, diamonds, or other valuable commodities, and exclusively applied like them to purposes of luxurious gratification.

The islands in the Indian Ocean yield some Indian isquantities of gold. Ceylon is said to have once afforded it, but at present none is extracted; nor are there any authentic accounts of that metal being found in Java.

Sumatra yields gold, both from the washing of Sumatra. the sand of the rivers, and from small mines in the mountains of Monangkabo. The several districts of the island are said to produce annually about thirteen thousand ounces of gold of nineteen carats fine. A small part of this metal is destined to increase the general stock of the world, as the chief application of it is to ornamental domestic purposes, and especially to gilding.

Borneo has been long celebrated for its abund- Borneo. ance of gold. It is chiefly found in alluvial deposits, whence it is extracted, both by natives and Chinese, but chrefly by the latter, who conduct their operations in a district between Samboss and Pontiana, called, from its chief town, Montradack. The whole tract is alluvial, being intersected by numerous rivers of considerable size, flowing from the mountainous interior. The Chinese population in this di- 
vision is estimated to be about thirty-six thousand, of which about one fourth part are employed in procuring gold, and the remainder in various branches of trade and agriculture. They are almost independent of the native chiefs, except that they pay an annual tax or rent of four thousand Spanish dollars to the Rajah of Samboss, in whose territory the mines are. 'These mines are longitudinal excavations, following the course of the mineral strata, and not exceeding sixteen feet in depth. The auriferous earth which is taken out during about thirty or forty days is washed, and it is said that in that space of time two hundred labourers will obtain from two hundred and fifty to five hundred ounces of gold, according as the particular spot excavated is more or less rich. The whole of the gold from this district has been estimated at eighty-eight or eighty-nine thousand ounces annually, and that of the whole island at about one hundred and twenty thousand.

Celebes.

In Celebes the gold is all found in the beds of the rivers in the form of a coarse sand. The inhabitants, though good seamen, are deficient in industry and skill, or at least direct them negligently when seeking for the precious metals. The whole amount of gold afforded is said not to exceed ten thousand ounces, and that so mixed with more impure substances as not to contain more than eighteen carats to the ounce. 
In the island of Timor, gold was formerly Timor. yielded both in grains and lumps, but the inhabitants are said to have an aversion to search for it, or even to touch it, and at one period assassinated a party of Dutchmen who had been sent into the interior to collect it. It is now found in copper ore, but the whole quantity does not exceed one thousand ounces ${ }^{1}$.

The Philippine islands are stated to yield annually about fifteen thousand ounces of gold ${ }^{2}$, which is chiefly found in combination with copper.

According to the accounts of those who visited Japan. Japan at an early period, that kingdom must have abounded in gold. Marco Polo relates that "they have gold in great abundance, but as it is not allowed to be exported, few merchants visit the country. The entire roof of the palace is covered with a plating of gold in the same manner as our churches are with lead. The ceilings of the halls are of the same precious metal. Many of the apartments have small tables of pure gold considerably thick, and the windows have also golden ornaments." (P. 569.) P. Amiot, whose narrative is of a later date, says, "Le Palais du Roi se fait remarquer par la manière singulière dont il est construit. Il a neuf étages, et presente de tous côtés un exterieur brillant de l'or le plus fiñ."

1 Description de Timor, par Van Hogendorp, dans les Annales des Voyages, t. vi. p. 280.

${ }^{2}$ Hassel, vol, xv. p. 820.

voI.. II. 
Kaempfer says, "Gold, the richest of all metals, is dug up in several provinces of the Japan empire. The Emperor claims the supreme jurisdiction over all the mines in his dominions, and demands twothirds of all that is procured; but of late, as I was informed, the veins not only run scarcer, but they yield not nearly the same quantity of gold they did formerly ${ }^{1}$."

As from all accounts these mines have of late become less productive, it may have arisen in part from exhaustion, and in part from the large share which the Emperor demands, which probably leaves too little to the miners to pay the expense. The whole quantity which Japan contributes to the general commerce of mankind is probably small, especially if the taste still prevails of applying large portions of it to the decoration of the imperial palaces, and to articles of domestic furniture. Though it might have appeared negligent to have omitted all notice of Japan, it cannot be thought, especially with our imperfect knowledge of the country, to have any important bearing on the subject of this inquiry.

On a review of the whole product of Asia, we should hardly estimate its annual amount, making an allowance for Ava, China, and Japan, at more than three hundred and eighty thousand ounces of gold, and two hundred and sixty thousand ounces of silver. If the former be valued at 1 History of Japan, vol. i. p. 107. 
three pounds five shillings, which, from its low degree of purity, must be the correct price of such gold, and the latter at five shillings, the value will thus appear:

380,000 ounces of gold at $3 l .5 s$.

260,000 ounces of silver at 5 s.

Silver in Turkey

Whole produce of Asia
$\mathfrak{E} 1,235,000$

65,000

100,000

$£ 1,400,000$ sterling.

From want of correct data, we find it necessary to supply their place with conjectures, and however remote those conjectures may be from accuracy, or however near they may approach to it, we entertain no doubt of the relative proportion of the two metals to each other being very near the truth, and that the value of the gold yielded by Asia is from ten to twelve times as much as that of the silver. From the earliest ages the exchange of silver for gold was going on between the western and the eastern world. Gold has been rarely used in Asia as money, either coined or uncoined. It was needed like precious stones to ornament the persons, the palaces, or the thrones of the princes. Its value was too great to be wanted in the usual commerce of the country, and in large transactions silver would be quite sufficient; whilst for those of smaller amount, brass coin or cowries were better adapted. Where gold did not perform the function of money, it would be of less value when ex- 
changed with other commodities than in countries where it was wanted to perform that office, and wherever it was most wanted it would naturally flow.

It is seen by the Appendix, No. 14, that within the twenty years from 1810 to 1829 , the treasure transmitted to Europe from India and China amounted to $£ 7,814,388$ sterling, and this was almost exclusively gold. It approaches so nearly to the whole amount which is here estimated to be annually supplied, that it becomes natural to consider in what manner the quantity left behind could satisfy the wants of the inhabitants. The quantity of coined gold is almost exclusively confined to the territories of the East India company. There both gold and silver are coined, but in proportions very different from what is practised in Europe. Thus at the mint at Madras, the value of the silver to the gold that is coined is as fifteen to one; of the rate at Calcutta we have not the exact proportion, but know generally that the former very far exceeds the latter.

The extension of the dominion of the East India company has lessened the number and diminished the splendour of the native independent princes. They were the persons who used or retained the greater portion of the gold. Before ourpower was extended, the several princes were either engaged in hostility or preparing for it. To them hoards of treasure were necessary, and though gold was not the 
usual current money, it could easily be exchanged for it, and its compendious nature, which was favourable to concealment, or facilitated its removal from one fortress to another, must have made it one of the best preparatives for their defensive or marauding operations. Gold was of use to them as an object of luxury, for the ornaments of their persons and their palaces, and the change that has taken place by curtailing their power has deprived many of the means of their most luxurious gratifications.

The security which has been given to the property of individuals, and the power of suppressing warlike operations between the native princes, which have both been the consequence of the British power, have rendered it unnecessary to form such large deposits of the precious metals as were known to be hoarded in former times by the several courts in India. That treasure which used to be inactive in the depositories of princes has been dispersed among their subjects, and thus without any increased production from the mines, and with a diminished importation from other countries, the inhabitants of India have from the greater diffusion of that which was formerly stationary, a sufficiency of metallic money to prevent any great decline in the prices of the various commodities they exchange for silver.

From the state of society in Asia, a much smaller quantity of the precious metals is necessary than 
in Europe, and in the parts of America settled by the English. In China and India, and in the other countries of the east, by far the greater portion of the inhabitants are employed solely on the cultivation of the land, and subsist chiefly on the productions they themselves raise. They have little to sell and little to buy, and consequently require the use of a very small portion of metallic or other money. Mr. Barrow, speaking of China, says, "In the province of Kiang-nan, each grows his own cotton; his wife and children spin it into thread, and it is woven into a web in his own house, sometimes by his own family, but more frequently by others hired for the purpose. A few bamboos constitute the whole machinery required for the operation. Money he has none; but his produce he can easily barter for any little articles of necessity or luxury. The only coin in circulation is the Tahen, a piece of some inferior metal mixed with a small portion of copper, of the value of a thousandth part of an ounce of silver. With this small piece of money the little and constantly demanded necessaries of life are purchased, such as could not conveniently be obtained by barter. Silver is rarely lent out to interest except between mercantile men in the large cities. The legal interest is twelve per cent.; but it is commonly extended to eighteen, sometimes even to thirty-six ${ }^{1}$."

1 Barrow's China, p. 562, 2nd edition. 
As China is supposed to contain one half the inhabitants of Asia, though in the territories longest ruled by the East India company the wealth of the inhabitants may be somewhat greater, yet as in many and extensive portions of that quarter of the world the same advance has not been made, and the condition of the people is much lower, we may consider the Chinese empire as a fair average of the whole of Asia. It will be readily seen that in such countries, notwithstanding some large operations of commerce may be carried on in a few of the trading cities, or at the large fairs, the demand for the precious metals must be very much less than is required by such communities as people the whole of Europe, and that part of America in which the English have founded establishments.

The money which circulates in Asia is chiefly of silver. This, as we have before shown, is much more susceptible of loss by wear than a currency consisting of gold. On that account the yearly quantity required to replace that which is consumed must be greater in proportion to the whole mass in circulation than is needed in Europe, where a large part of the money consists of the more durable metal gold. On the other hand, it deserves to be considered, that in the east, especially in India, more care is taken by every individual to preserve the money from friction than is practised in Europe. This may arise from the greater value of the pieces of money when compared with other commodities; 
but it has escaped the notice of no observing traveller in India that the natives, who have any rupees or other coin, instead of carrying them in a purse together, wrap up each piece singly in a cloth to prevent loss by rubbing. A less loss must have been suffered from friction also, owing to the general practice adopted by princes and others in times of insecurity of hoarding treasure. In their vaults it would suffer nothing; and in an experiment which we have seen recorded, some silver money which had been hoarded in the treasury of a native prince had lost in weight only at the rate of one per cent. in thirty years, whilst a parcel of other rupees of the coinage of 1759 and 1760 , which had been in general circulation, had in twenty-three years been worn so thin as to be no longer passable, except by weight, and at a consequent great loss.

As far as can be known by any examination within our power, it does not appear that any great changes have taken place in Asia, in the prices of articles which form the principal means of subsistence. There may have been variations caused by the greater or less productiveness of seasons, or by the improvement or deterioration in the modes of cultivation, or in the administration of the several governments ; but there have been no such changes as were universally experienced in Europe on the introduction of the produce of the mines of America, or of such as have been since occasioned 
in the United States of America by the emission of paper dollars-in France by the circulation of assignats-in Russia by the excess of paper roubles -in Austria by her issuing a superabundance of paper florins-or as was felt in England by first deviating from, and then returning to, a currency in the precious metals. We are then justified in concluding that the supply of the precious metals to India, China, and the rest of Asia, has been nearly that which was required to maintain an equable proportion between them and the mass of other commodities.

Whilst the mines of Asia have not increased their products, the importations of treasure have lessened, and yet no sensible decline in general prices has been experienced. The dispersion of the hoards which had been heaped up during the times of the insecurity of property has probably been found sufficient to render prices steady.

As the population of Asia may be taken at about double that of Europe and America, and as we have seen that the quantity of the precious metals consumed in the two latter divisions of the globe is to that obtained by Asia in the proportion of five to two, we may conclude that the use of them is ten times as great among the Europeans and Americans taken by the individual as among the Asiatics; but as the prevailing metal in Asia is silver, and a great part in Europe is gold, and as silver wears much faster than gold, we must conclude 
that the annual supply required to keep up the stock is proportionably greater for Asia than for Europe.

If the annual consumption, or rather application, of gold and silver in Asia be compared with that in Europe and America, taken according to the estimated number of individuals in the respective divisions of the globe, the former will be seen to be much less than the latter. If Asia contains five hundred and forty millions of inhabitants, and consumes yearly gold and silver to the amount of three millions four hundred thousand pounds sterling, it will amount to no more than one penny halfpenny per head. If Europe and America contain together two hundred and seventy millions of people, and consume yearly in gold and silver to the amount of nine millions sterling, it will amount to eight-pence for each individual. Viewing the advanced state of society in Europe, and in that part of America peopled by the descendants of the British islands, and comparing it with the state of Asia, we are disposed to consider the rate here noted as not an improper one to be applied to the relative general material wealth of the two divisions of the world. It is not, however, applicable to the proportions of metallic wealth. That of Asia, as it consists in a much greater degree of silver than it does of gold, to keep up the same stock, as that metal consumes faster, must require a greater proportion of annual supply. 
If we were to consider the coined and uncoined gold and silver in Europe and America to be represented by a thousand millions sterling, and we were to apply to it this scale, we should estimate that of Asia as little short of two hundred millions, which would be about fifty millions more than would be found when due allowance is made for the greater wear of silver, and than we are disposed to think, on considering the state of the eastern part of the world, is actually existing there. 


\section{CHAPTER XXVIII.}

On the proportion which that gold and silver which is coined bears to that existing in other forms.

WE have seen that the consumption of gold and silver, and the application of those substances to other purposes than the fabrication of coin, has, in the last twenty years, exceeded that supply of them which the mines have afforded. The greater part of those metals are converted into coin almost immediately on their being extracted from the mines. This is the case with nearly all that is collected in what was Spanish America, with the gold of Brasil, and with that obtained from the Russian mines. It must then have been from the stock of coin either recently or antecedently formed, that the gold and silver that have been consumed or appropriated to purposes of ornament must have been drawn. It may be safely inferred that the quantity of coin actually in circulation at the end of the term of twenty years had been diminished. If the view we have taken be correct, that diminution must have amounted to one-sixth of the whole circulating coin of Europe and America.

How far the portion of the precious metals thus withdrawn from coin and applied to ornamental 
purposes may have increased the stock of the latter, or have increased it at all, is a matter of great doubt. It must depend on the quantity of the latter which is actually in existence, and on the degree of loss to which that quantity is liable. Many persons have indulged in conjectures on both those topics. Some have estimated the value of the gold and silver in the form of utensils and ornaments to be three, and others four, times as much as that of the coin. They appear, however, to have taken only a partial and local view of the subject, and to have come to their conclusions from observations made in EngIand, where, undoubtedly, the whole weight of gold and silver in other shapes is far greater than that in coin.

An analysis of the classes of society in this country may do something to assist conjecture. There probably are in England ten thousand families, consisting of about one hundred and fifty thousand individuals, including children and domestics, who are in possession of articles of gold and silver whose value by weight, when divested of the additions made by the tax, by the workmanship, and by the profits of the manufacturer and the retailer, may together amount to five hundred pounds for each family; or may be worth, as mere bullion, five million pounds sterling, although it may have cost to the possessors much more than double that sum. We 
may allow for such families, in gold and silver coin, fifty pounds, and considering that the heads of such families generally keep more bank notes than money, and discharge most demands on them by orders on a banker, and that the children and domestics have seldom more than a few shillings, this estimate will be judged sufficiently high. With this class then the value of their manufactured gold and silver may be ten times as much as that of their coin of those metals.

A number of families of inferior wealth may be classed together. This class, comprehending such as would average an annual income of one thousand pounds, may be in number about one hundred and fifty thousand, and include one million five hundred thousand individuals. If these, taken together, possess as much of plate, and of gold and silver in jewellery, as have cost one hundred pounds for each family, the value of it in weight will be greater in proportion to the cost, because it will consist chiefly in silver spoons and forks, and in gold and silver watch-cases. The workmanship of these is much less, and the profit of the manufacturer and retailer is also less than that of the highly ornamented and elaborately worked plate of the superior classes. With persons in such circumstances the amount of coined gold and silver will commonly be found to be less than that possessed by those of higher expenditure. 
If we estimate their coin at twenty pounds for each family, it will then be exceeded by the value of their plate, reduced to weight and disposed of as bullion, in the proportion of three and a half to one.

At every step that we descend, in the classes of society, it will appear that the coined money and the gold and silver utensils and ornaments in the possession of families gradually approach to each other in their intrinsic value, till they come to the class of the very lowest day labourers, whose money, small as it is, usually exceeds the silver or gold they can retain, although some of those who subsist by their labour alone, may have some small article they prize, such as a wedding ring or silver spoon, and which are commonly the last that necessity compels them to part with.

'There is one description of persons whose wealth may not be great, but whose stock of plate must be much larger even by weight than their coined money. These are the keepers of taverns, hotels, coffeehouses, inns, and down to the smallest publichouses in the ten thousand villages of England. To their excess of gold and silver above their coin may be added that which is accumulated by the several corporate bodies within the kingdom. These include that of the corporation of London, that of the several rich guilds or companies in the city, some of whose stock of plate is large, that of the inns of court, of the several colleges of $\mathrm{Ox}$ ford, Cambridge, Eton, and Winchester, and of the 
hundreds of corporations in the several cities and towns of the kingdom. Besides all these stores of articles of furniture chiefly of silver, there are in the twelve thousand parish churches of England, and in the thousands of protestant dissenting, to say nothing of the few catholic, chapels, a greater or less store of plate for the public service of our modest and simple forms of devotion, which, varying as they do in value from one to one hundred pounds in each, must amount in the whole to a large sum.

The largest accumulations of gold and silver are, however, those in the shops of the numerous gold and silversmiths in the several cities and towns of this kingdom, and in the workshops of the various manufacturers who supply goods to them, and to the merchants who export their wares to other countries. There is good reason to believe that no one class of traders in this country keep so large a stock of wares by them, in proportion to their actual sales, as those who deal in gold and silver goods; but especially in the higher kinds of jewellery in which the most gold is employed. The perpetual changes of fashion in articles of mere ornament are cherished by the constant exercise of the faculties of tasteful invention, and these render a succession of new objects indispensable to the traders, though thereby the value of the remainder of their goods becomes gradually lessened, till they are worth no more than what the gold, which composes a part of them, will fetch as bullion. 
The effect of this state of the trade is to keep a large portion of gold in a constant state of inactivity. We have seen the annual supply of gold demanded by our jewellers estimated at $£ 1,636,700$, and we are induced to believe after much inquiry and consideration, that the stock of that metal in the process of manufacturing, with that in the shops of the various dealers in jewellery, amounts to full four year's' annual demand, or according to the view taken in the 26th chapter, to $£ 6,546,800$.

If we assume the stock of silver in the hands of the manufacturers and dealers to be in the same proportion to the annual demand as that of gold, it will amount to $£ 3,280,000$, and the value of the two metals thus in a state of transition will appear to be $£ 9,926,000$.

We have hitherto considered only the quantity of coined gold and silver in the possession of individuals arranged according to supposititious classes. We must, therefore, now notice the accumulation of coin in the hands of that great corporation the bank of England. The stock of gold and silver in the vaults of the bank cannot be accurately ascertained, but sufficient notices of the state of their treasure at particular past periods have come before the public, to ground assumptions that cannot generally be very far from the truth. We estimate then that in London, in the branch banks, and in the hands of the London and VOL. II. 
country private bankers, the stock of gold and silver is one third of the whole metallic currency of the kingdom. On that supposition, the amount of both the precious metals in the hands of the manufacturers and dealers will be about equal to the reserve stock in the hands of the bank and the bankers. By comparing the different classes of society and their possessions in plate and jewellery in the gradations before pointed out, we arrive at the conclusion, that the actual value of all the gold and silver in articles of dress and furniture does not exceed the value of the coin of both metals in more than the proportion of two to one. In other words, taking the amount of the coined money at thirty millions, we should calculate the remainder of the two metals at sixty millions.

It has appeared the more necessary to extend our remarks on this subject, because the view here taken differs from what has been commonly presented. We are disposed to think that those who have estimated the gold and silver in ornaments and utensils at four times as great as that in coin, have been induced to do so by estimating plate and jewellery at the prices they cost to the owners, and not as is done here, according to their value when brought to the crucible of the refiner.

In France, the proportion between the coined money and the plate and jewellery is very different from what exists in England. The currency consists almost exclusively of metallic 
money, and therefore naturally exceeds that in England, where, from the state of credit and confidence in the bank and in private bankers, so great a proportion of coin can be dispensed with. In France, great pains have been taken to ascertain the amount of the coined money, which forms nine-tenths of the currency. The estimates vary for different years, and according to various inquirers, from two thousand million to two thousand five hundred million francs, or from eighty to one hundred million pounds sterling; or to state it more explicitly, the average quantity of coined money to each person in France is at a rate between two pounds fourteen shillings and three pounds two shillings per head.

The plate in use in France is commonly much lighter than that used in England. The jewellery that is worn is more ornamented. Neither one nor the other extends to such numerous bodies of the inferior classes; and we should conclude, as far as the observations of a traveller can allow a judgment to be formed, that the value of the coin in France, supposing it to be as great as the authors of the inquiries affirm, cannot be less than that of the other precious metals if the latter be sold by weight.

In every other country of Europe, except Russia, Sweden, and Portugal, the metallic money very much exceeds the paper, and generally in a proportion equal to that of France. 
The plate and jewellery are very lightly distributed, both in quantity and value, and we are disposed to estimate it not higher, as mere bullion, than the value of the coined gold and silver. In the United States of America, in the British continental colonies of that division of the world, and in the West India islands, we should suppose the proportion between the precious metals in money and that in ornaments and furniture to be nearly the same as in England; and considering the quantity of paper money which has inundated some of the new states of Spanish and Portuguese South America, the relative quantities of metallic money may be nearly the same as in England and North America.

Taking this extensive view, it can scarcely be calculated that at the present time the actual value of the precious metals in personal ornaments and in domestic utensils in Europe and America, supposing them to be brought to the crucible, exceeds by more than one-fourth that of the coined metals, or amounts to more than four hundred millions.

These portions of uncoined metals may become a resource in time of need to supply the deficiency in the coin, occasioned by the defalcation in the mining countries. In England, a tax of thirty per cent. on the fabrication, which practically applies to silver extensively, and to gold in a minute degree, operates to prevent the uncoined 
precious metals from being converted into coin. In the other parts of the world no such tax exists. In times of great agitation and insecurity, especially during internal commotions or invasions, gold and silver articles are rapidly converted into money; whilst, during periods of tranquillity and prosperity, money is converted into plate and jewellery. In the latter case confidence gives currency to various substitutes for coined money, and its use may be greatly abbreviated; but in the former case nothing can be used as a substitute, since the credit of public or private institutions of a banking nature, from whence such substitutes can alone originate, can never enter into an equal competition with metallic money. 


\section{CHAPTER XXIX.}

On the prospect of future supplies of the precious metals.

IT has been seen in the preceding chapter that the prospect of increasing coined money by converting utensils and ormaments into it, depends on the state of tranquillity or of turbulence of the several countries : in the first state, as substitutes can be used for coin, it becomes less necessary; and in the second case, as such substitutes are unmaintainable, the coin will be likely to receive additions from those various articles in which the precious metals have been employed. There may be action and reaction by which the quantity of coin may be diminished or increased, whilst in the whole portion of the precious metals in existence there may be no general increase, or there may be even a considerable decrease.

The only general increase that can be contemplated must be from an augmentation of the product of the mines, and it will not, therefore, be irrelevant to our purpose to consider the probability of any large additions being made in future to the quantities at present afforded from these sources.

We have seen, during the whole course of this inquiry, that mines of the precious metals have 
only been worked at the expense of great toil and suffering of the people employed in them. In the earlier ages of the world, the extension of slavery, and of the most oppressive kind, was the natural consequence of pursuing this description of labour. In more modern times, since the discovery of America, the working of the mines could only be effected by the forced labour of the native inhabitants, and their numbers were rapidly thinned by the severe cruelties and privations to which they were exposed by their new masters. In the washings for gold, whether in Africa or Asia, we have seen that the condition of those so occupied is that of almost the lowest of human beings. If of late years Mexico has been an exception to this general representation, if the labourers have been better treated and better maintained, it has arisen from local and fortuitous circumstances, from the minerals being found in larger beds, and from the application of larger capitals to their extraction and refining. In these circumstances, the loss has been rather that of the wealth of the adventurers than of the lives and sweat and strength of the labourers. In spite of a very few instances of most unusual success, but a success which has enticed to their ruin many other capitalists, the profit of mining, even in Mexico and under the most favourable circumstances, has been far less in proportion to the capital devoted to it than that derived from agri- 
culture or from the ill-managed manufactories which supply the greater part of the wants of the inhabitants of that country. If, however, capital could be beneficially employed, it would take a long period before that which twenty years ago existed in Spanish America could be again collected in the several countries where the mines are situated. The commotions which have unceasingly prevailed since they renounced their connexion with Spain have had the effect of expelling whatever capital was moveable. Silver and gold were the chief produce, and from their compendious nature could, either by law or against law, be easily carried away. We know that from Peru, in seven years, more than double as much silver was sent to Europe by British ships of war alone as all the mines afforded. The author was assured by Iturbide that during the space of little more than one year, when he filled the office of emperor in Mexico, there was exported from that country to Europe, to the United States, to Cuba, and the other West India Islands, in coined money and bullion to the amount of more than one hundred and twenty million dollars. Ever since that period, each ship of war and packet that has arrived has brought large sums to our merchants on account of persons who have removed to Spain or the south-west of France, or other countries where bills on London could be negotiated, and the property be thus easily and safely conveyed to its real owners. 
Much of the capital that existed in Spanish America has been removed to the island of Cuba. Although the loss attendant on the abstraction was enormous, yet, having been invested in agriculture, it has increased the productions of that island, and notwithstanding the low prices of sugar and coffee, has left the capitalists such a profit and given them such a sense of security as would be sufficient to prevent its return to the distracted countries from which it had escaped.

Estimates have been framed of the amount of capital abstracted from Spanish America, in consequence of its commotions, which carry it to an enormous extent. Without adopting any of these, we may safely maintain that it has been replaced in a very trifling degree by the operations of the mining associations, formed chiefly in England, and on a smaller scale in other parts of Europe and North America. The amount of these aids to mining, which cannot exceed four or five millions sterling, (a great part of which was improvidently squandered before their operations commenced), can have no perceptible influence on the future production of the precious metals, even if the parties who conduct them should acquire sufficient practical knowledge to work the mines with profitshould retain sufficient perseverance to continue a uniform course-and sufficient confidence with the public to obtain fresh supplies of money. These European efforts, however, will manifestly appear 
very insignificant if it be considered that the whole capital of all the companies, supposing them to remain undiminished when their actual operations commenced, would certainly not amount to a fiftieth, perhaps not to a hundredth, part of what has been lost to America, or transmitted to Europe.

It is evident from all the accounts which have reached Europe from Columbia, Peru, Chili, and Buenos Ayres, that a great scarcity of labourers is there experienced. The large proportion of the population in these thinly peopled countries which has been compelled to become soldiers may account for this, but the fact is so strongly stated in every report from thence as to leave no doubt of its accuracy. Though the inhuman trade in slaves has continued to convey negroes from Africa to Cuba, none have lately been carried to the continent. Those who were in a state of slavery on the plantations in Columbia have been liberated, but being thus freed were almost universally pressed into the military service. The white inhabitants are too idle or too proud to labour, as long as they can subsist on the productions of those more fruitful soils, where a few days' labour will raise food for a year's support-where little clothing and less fuel are required, and where a shed serves the purpose of a dwelling. In such circumstances few will work with assiduity, and none without higher inducement than the hope of obtaining luxuries 
with which they are unacquainted, except by report.

Under all the circumstances of Spanish America, considering the small profit that mining as a whole yields, with the want of capital and the scarcity of labourers, there seems no more reason to conclude that any material increase can take place in the extraction of the precious metals than there is to suppose that the agitations and commotions which have long prevailed will speedily terminate, or such a state of society be attained as will afford security and protection to persons and to property.

In Brasil the gold is chiefly obtained by the labour of slaves brought for that purpose from the shores of Africa. How long the more civilized parts of the world may ineffectually strive for the abolition of that inhuman traffic it is difficult to foresee. The continuance of the present state of society and the present form of government in that country is equally difficult to anticipate. From all accounts an explosion is not unlikely to take place, which may divide that country into as many distinct communities as are to be seen in the Spanish parts of the new world. Bahia and San Paulo have no natural connexion with each other, and there is still less between Pernambuco and Minas Geraes. The whole empire is a most incongruous mass, and more likely to dissolve into some anarchical forms than to settle into such a state of security as will induce any great increase of its metallic productions. 
The mines which Russia is now working are under circumstances materially different from those of America. Our details of the workings are too imperfect to enable us to judge how far the benefit derived from them is likely to induce any great extension of their operations. The government of Russia and numerous individuals have an almost unlimited command of labour. The Cerfs who are destined to perform it are accustomed to subsist on the coarsest kinds of food, and to be supplied with other necessaries in a much more parsimonious manner than the workmen under other European governments. They may thus be enabled to yield a greater profit to their masters by the extraction of the precious metals than they could by employment in agriculture, in situations far removed from any market for agricultural produce. The easy transfer of the metals may alone make the search for them a more beneficial application of labour than the cultivation of hemp, flax, or rye, which are too heavy to defray the expense of a long land carriage, or even a conveyance by inland river navigation.

On a review of the several countries which yield gold and silver, no very sanguine hopes can or will be indulged that a great or material increase in their production is likely to take place in the course of a few years. 


\section{CHAPTER XXX.}

On the amount of paper money.- On the decline of prices.Conclusion.

IT has been calculated in the twenty-sixth chapter that between the end of the years 1809 and 1829 the current coin in Europe and America had been diminished from three hundred and eighty to three hundred and twenty millions, or in the proportion of one-sixth part.

During the whole time the currency of both countries consisted in part of various descriptions of paper money, which acted in aid of the metallic money in the interchange of commodities. This paper money was in different periods and in different countries at various degrees of depreciation, but in every case it retained some value, according to which gold and silver might have been purchased with it. We may therefore appropriately examine what proportion the paper money that circulated bore to the coined metallic money. It will be desirable, also, in the course of the examination, to inquire if the value of the paper money, taking for that value the power of purchasing gold and silver with it, was 
greater or less at the end than at the beginning of the period.

Russia differs from all the other divisions of our part of the world in not having returned to payments in metallic money. When its paper money was first issued, and the quantity small, the rouble was worth about three shillings and fourpence sterling, or of the same value as the silver coin of that name. The increased quantity gradually depreciated the metallic value of the paper till one silver rouble was worth four paper roubles. It had nearly attained this low value in 1810, when the paper roubles amounted to five hundred and seventy-seven millions. It was nearly of the same, but somewhat greater, value in 1830, though the amount had increased to six hundred and thirty-nine millions.

Taking the paper rouble at one twenty-fifth part of a pound sterling, the value of the whole mass of paper money in the Russian empire was in 1810 twenty-three millions, and in 1830 twentyfive millions and a quarter. As there had been an increase in the value of the rouble when measured by the precious metals, we may assume that all the paper money of Russia possessed nearly the same power of purchasing gold or silver in the year 1830 as it had in 1810.

In Austria the paper money known by the name of Wiener Whärung had increased till it amounted nominally to one thousand and sixty millions of 
florins, and had at one period depreciated to such an extent that a silver florin could purchase ten or twelve paper florins. That great depreciation continued but a short time, and after the peace with France in 1810, and the subsequent marriage of Buonaparte with a daughter of the Emperor, a silver florin continued to be worth five paper florins. If it be taken at that rate in 1810 , and the silver florin be valued at two shillings sterling, the value of the paper money circulating in Austria in 1810 would be nearly twenty-one millions if used to purchase gold and silver. A return to specie payments was effected in Austria about six years ago, by an arrangement which could not have been adopted in a country where credit is essential to prosperity. The old bills were exchanged for new bills of two-fifths their nominal value, which new bills were payable on demand in silver money. The loss of three-fifths of the value of whatever paper money was in circulation fell on the individuals who held it; but as it was thus equally distributed, and as the new currency was of greater power in the purchase of all commodities than the old, the arrangement was attended with less inconvenience and dissatisfaction than could have been anticipated.

It is not possible to state with moderate accuracy what may be the amount of paper money in circulation in Austria, now that it is all exchangeable on demand, for specie; but, from opinions collected 
in Vienna at the time the above-mentioned operation was carried into effect, from what is known of the large negotiations at Frankfort to obtain supplies of the precious metals - from the abundance of silver and gold coin to be seen in every part of the empire-from the preference given to it in all smaller transactions-it may be inferred that the paper money now circulating at par does not exceed one half the whole currency, or does not amount to more than one hundred million florins, or ten millions sterling.

Prussia had no paper money in circulation in 1810, for its Tresor Scheine were of the nature of our exchequer bills; but of late its bank has risen in credit. 'Though its bills are received as cash in the payment of all taxes and public contributions, the circulation is not extensive, and supposed not to exceed twelve million Thalers, or two millions sterling.

In Holland, where in 1810 there was none but metallic currency, a bank was established in 1814, with a capital of four hundred thousand pounds sterling, which was doubled in 1819; but its circulating notes are not supposed to exceed one million sterling.

In the smaller states of Germany, in Italy, except as regards that part of it which is under the dominion of Austria, in Spain, and in Switzerland, the currency has been invariably metallic.

In Denmark, Norway, and Sweden, a paper 
currency existed in 1810 , and still circulates; but the whole amount, as well as the variations in those countries, has been so small that they affect in a very trifling degree the view here taken. The same is the case with Portugal, where, in 1810, paper cruzados to the amount of about two millions circulated with a degree of depreciation varying from twenty-five to thirty-one per cent. of their. nominal value.

We come now to consider the amount of the paper money in France at the two periods when we have viewed that of the other countries. After the banishment of the assignats, the mandats, and the other paper which had inundated France during the revolution; in 1803, the bank of Paris was established. It became involved in difficulties in $\mathbf{1 8 0 5}$, which were removed in 1806 , when a new system for its management was introduced, and a prolongation of its charter granted. In 1810, the degree of confidence it had obtained enabled it to circulate its notes to the amount of somewhat more than two millions sterling. Notwithstanding the early events of 1814 , it had increased its circulation up to July, 1830, when it is reported to have amounted to about nine millions.

If we look at the paper money which circulated in the British islands between the years 1810 and 1830 , though we shall see much variation in its nominal amount, we shall find that its whole value, VOL. II. 
as applicable to the purchase of gold, varied but little during the course of the term.

Although we have accurate knowledge of the amount of bank of England notes in circulation, yet we must depend on estimation as far as regards the notes of private bankers in England, of the corporate and joint-stock companies of Scotland, and of the paper circulation of Ireland. We shall therefore assume that the bank of England notes were equal in amount to the notes of all the other descriptions which circulated in the united kingdom. In the year 1810, the bank of England notes were about twenty-four millions, and the other paper monies being equal, the whole may be taken at forty-eight millions. The price of gold at that time was four pounds ten shillings the ounce. The whole paper money would then have purchased ten million six hundred and sixty-six thousand six hundred and sixty-six ounces of gold. In the year 1814, the bank notes amounted to thirty millions, and that of the other kinds being supposed to be equal, the whole would be sixty millions. The price of gold was five pounds ten shillings, and the paper money would have purchased ten million nine hundred and nine thousand and ninety ounces of gold. In the year 1829, the average circulation of the bank was nineteen million nine hundred and forty-eight thousand pounds, or twenty millions; and, taking 
the other circulating paper at the same amount, the forty millions would have purchased ten million one hundred and sixty-nine thousand two hundred. ounces of gold at seventy-seven shillings and tenpence halfpenny per ounce, the price of the day.

In the United States of America the paper notes of the numerous banks of that country were all payable on demand in specie, in the year 1810. During the war with England, which was terminated before extensive hostilities had commenced, almost all the banks of America suspended their payments in metallic money. They have now, however, returned to payment in specie, and though their establishments have regained full credit, the whole circulation cannot much exceed that of 1810. From very accurate accounts, as communicated in a publication of a distinguished statesman of that country, Mr. Albert Gallatin, it appears that the paper circulation of the United States amounted at the end of 1829 to sixty-two million and a half of dollars, or in sterling money to somewhat more than thirteen millions.

From this review it is seen, that there has been no such alteration of the paper money in the twenty years we have been considering as could affect the value of commodities when measured by the precious metals. The paper money has fluctuated in its nominal value, but the whole quantity of it has been able to exchange for nearly the same weight of gold or silver, whatever those 
fluctuations may have been. Thus our bank and other bills in 1810 would buy a little more than ten million ounces of gold when they amounted to forty-eight millions nominally; they would purchase nearly the same weight in 1814, when they had reached sixty millions; and almost as much when, in 1829, they had sunk to forty millions; and the same effect may be traced in the other countries where paper money was issued.

The paper money which thus acted the part of an auxiliary to the metallic money amounted in metallic value to about one hundred and twenty millions during the whole period; but the whole of it cannot be viewed as coming in aid of the coined money. A reserve of coin must have been retained in deposit as a resource to meet unforeseen demands, or as a preparation for that which was looked forward to, with different degrees of intensity at different periods, namely, a return to cash payments. It may perhaps be allowable to assume that coin of the value of one-third of the paper money was withheld from circulation, and that only two-thirds or eighty millions of paper money were available to the currency for the general purpose of the interchange of commodities. We should thus have had a circulating medium in 1810 of four hundred and sixty millions, and in 1830 of four hundred millions.

If the prices of commodities were regulated solely by the quantity of the circulating medium, 
as the latter in the twenty years had declined at the rate of thirteen per cent., we might calculate that the fall on the former would be at the same ratio. If, as we know to be the fact, the mass of commodities had been greatly increased in the period, whilst the circulating medium had diminished, we should find an additional decline in the prices of commodities. But that decline would be liable to counteraction from several causes which might give additional power to the circulating medium, and enable a less portion of it to perform the same office as in other circumstances would require a larger portion.

In 1810, from the state of the whole of Europe being engaged in war, both the treasuries of the several states and the military chests of the various armies must have caused a large quantity of the existing money to have been in a state of inactivity. The difficulty of conveying money from place to place was great, and the internal negotiation of bills of exchange in most parts of the continent was suspended. Each man who had money kept it by him, instead of lodging it in the hands of banks or bankers, because none of them enjoyed security or possessed credit. In 1830 the case was altered. The conveyance of money was easy, secure, and especially rapid. If gold was more valuable in one place than in others, a few hours could convey it by steam vessels to the spot where it was wanted. Banks were established every 
where, which furnished inland bills to the parts of the same country, and foreign bills to other countries, which in many cases made the removal of specie unnecessary. The exchequers of states could rely on their credit to supply the place of money till it could be collected from the regular sources, and as no armies were on foot, there was no money kept in a state of inactivity in the military chests.

From these altered circumstances, whose influence it is difficult to calculate, the depression of prices, which would be the natural result of a diminution of money, and an increase of exchangeable goods, has been either prevented or lessened.

If it should be thought that the increase of the mass of material wealth in Europe and America has kept pace with what we know to have been the increase in the population of those divisions; it may be stated at about thirty-two per cent. in the twenty years, which, added to thirteen per cent. diminished in the mass of money, would cause a natural decline in prices at the rate of forty-five per cent.

This rate of decline would be retarded by the increased power given to money from the several causes which have been alluded to. It is difficult to determine, in such a complex system of exchanges of material wealth as is established in all highly civilised countries, how far a declining quantity of money is counteracted by the addi- 
tional power given to it. It is much more difficult to calculate the additional power than it is to estimate the decline in quantity.

It was intended to have been shown from the prices of a numerous list of articles in the year 1810 , and of the same in 1830 , what had been the degree of decline on the metallic value of commodities; but it was found impossible to frame any list in which the alteration of prices had not evidently been affected by other causes than the diminished quantity of the circulating medium. Thus, the article of corn, which is of the greatest amount, has been subject to such restrictions that it is impossible to determine what its price would have been in any country at any time, if a perfectly free trade in it had been allowed. We cannot calculate the influence of those restrictions more than we can the effect of the calamitous harvest of 1816 , or of the return to general peace in 1815 . Other commodities, as iron, may have had their relative value to gold and silver disturbed by improvements in mechanical means of dispensing with human or other animal labour. Some articles, as lead, may have had their relations affected by the opening of more productive mines. Monopolies, such as exist in some branches of the trade in coal, and as during the war operated on alum, may tend to deviations from the natural price of the articles. Speculations also may have a great temporary effect, as has 
been seen in the prices of cotton, of wool, and of tobacco within a few late years.

As it is not possible to frame a satisfactory catalogue of commodities that can be viewed as a criterion by which to try the value of gold and silver, we may venture to have recourse to classes of society in the different countries.

The cultivators of the soil are the most numerous part of the community. Their products are the least complicated in their origin, and the most simple in their distribution, and therefore are likely to be first affected by any increase in the value of the precious metals. They would be the first to experience the difficulty of obtaining the usual weight of gold and silver, if those metals became more rare, for the usual measure of corn, of meat, of cotton, of wool, of sugar, or other agricultural products. In this country, where the cultivators are a class of capitalists distinct from the proprietors, their capitals have generally been diminishing, whilst the decline of the mines has been proceeding, and the application of their produce to other purposes than that of coin has been increasing. It certainly does not follow from these two courses having been in simultaneous progression that one is the cause of the other. The same has been the condition of the cultivators of the soil in every other country; as far as it is accurately known. In every part of the continent of Europe the same complaints are 
heard, however various may be the tenures by which land is held. Such complaints are not bounded by the limits of Europe. The cultivators in North America assert that the prices of their productions yield them no profit, especially those of corn, cotton, tobacco, and rice. The same is the case in the West India Islands, and according to the common reports, in South America, and in India. There must be some general cause producing such extensive effects, which are thus felt alike where taxation is high or low, under despotic and free governments; and whether the land is cultivated by slaves, by serfs, by hired labourers, or by proprietors.

It would lead into a field far too extensive to speculate on what would be the effect in another twenty or forty years, if the same difference should continue between the production and the consumption of the precious metals, as appears to have been in operation during the past twenty years. It may, however, be observed that the world is very little really richer or poorer from the portion of metallic wealth that may be distributed over its surface; that the whole mass of material wealth is neither diminished nor increased by any change in the relative weight of gold and silver to the usual measures of other commodities. The only benefit to the world in general from the increase of those metals is, that it acts as a stimulus to industry by that gradual rise of money 
prices which it exhibits to the view. The only evil from the diminution of these metals is the discouragement it may present to industry by the apparent loss, or lessened profit, when the result of labour is reckoned in gold and silver and not in other commodities. It matters little to him who raises a bushel of wheat whether it is exchanged for a pennyweight or for an ounce of silver, provided it will procure for him the same quantity of cloth, shoes, liquors, furniture, or other necessaries which may be desirable to him. The relations of the different classes of society to each other, but still more those of different individuals to each other, will be changed, but the change will be made very slowly, and be scarcely perceptible in one or two years, and even at the end of a generation only noticed by those who look back with the means of comparing the range of prices at different periods.

In the twentieth chapter of this inquiry a view has been taken of the effect produced by an advance of the prices of commodities, in general, at the rate of five to one in the course of a century. The reflecting reader will easily perceive that an operation of an opposite kind may take place, which may no more derange the general economy of states, and no more disturb the relations of classes of society to each other, than was experienced between 1490 and 1590 . 
A P P E N D I X. 
Minute, 16th

Experiment made on a given number of each denomination of gold and loss by wear in

The officers of the Mint being desirous of ascertaining the wear on the experiment was made on a given number

\begin{tabular}{|c|c|c|c|c|c|c|c|c|c|c|c|}
\hline \multicolumn{2}{|c|}{ Denomination and date of Coin. } & \multirow{2}{*}{ 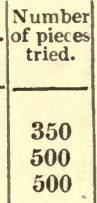 } & \multicolumn{4}{|c|}{ Computed weight. } & \multirow{2}{*}{\begin{tabular}{|l|l}
$\begin{array}{c}\text { Reduction for } \\
\text { pix report. }\end{array}$ \\
grs. \\
3.68 \\
$\mathbf{1 . 6 2 4}$ \\
$1 \cdot 931$
\end{tabular}} & \multicolumn{4}{|c|}{ Reduced weight. } \\
\hline Sovereigns & & & $\begin{array}{r}\text { lbs } \\
7 \\
10 \\
10\end{array}$ & $\begin{array}{r}\text { oz. } \\
\mathbf{8} \\
8 \\
8 \\
\end{array}$ & $\mid \begin{array}{r}\text { dwts. } \\
17 \\
8 \\
8\end{array}$ & $\begin{array}{r}\text { grs. } \\
18 \\
5 \\
5\end{array}$ & & $\begin{array}{r}\text { Ibs. } \\
7 \\
10 \\
10\end{array}$ & $\begin{array}{r}\text { oz. } \\
5 \\
8 \\
8\end{array}$ & $\begin{array}{r}\text { dwts. } \\
16 \\
7 \\
7\end{array}$ & 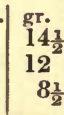 \\
\hline Half-sovereigns & $\left\{\begin{array}{l}1817 \\
1820\end{array}\right.$ & $\begin{array}{l}300 \\
230\end{array}$ & $\begin{array}{l}3 \\
2\end{array}$ & $\begin{array}{l}2 \\
5\end{array}$ & $\begin{array}{l}10 \\
10\end{array}$ & $\begin{array}{l}11 \\
16 \frac{1}{2} \\
10\end{array}$ & $\begin{array}{r}\left.\begin{array}{r}1.568 \\
=1.5 \\
\times .6 \\
-.6 \\
=.9 \\
=1.9 \\
\times 1.5 \\
=1.5\end{array}\right\} \text { pix. } \\
\text {. }\end{array}$ & $\begin{array}{l}3 \\
2\end{array}$ & $\begin{array}{l}2 \\
5\end{array}$ & $\begin{array}{l}10 \\
10\end{array}$ & $\begin{array}{r}6 \\
14\end{array}$ \\
\hline Half-crowns & & $\begin{array}{l}300 \\
300 \\
300\end{array}$ & $\begin{array}{l}11 \\
11 \\
11\end{array}$ & 4 & $\begin{array}{l}7 \\
7\end{array}$ & $\begin{array}{l}6 \frac{1}{2} \\
6 \frac{1}{2}\end{array}$ & $\begin{array}{l}3 \cdot 39 \\
3 \cdot 21 \\
5\end{array}$ & $\begin{array}{l}11 \\
11\end{array}$ & $\begin{array}{l}4 \\
4 \\
4\end{array}$ & $\begin{array}{l}5 \\
5 \\
2\end{array}$ & $\begin{array}{l}18 \\
22\end{array}$ \\
\hline Shillings & & $\begin{array}{l}300 \\
300 \\
300\end{array}$ & 4. & 6 & $\begin{array}{l}10 \\
10 \\
10\end{array}$ & 21 & $\begin{array}{l}3 \cdot 39 \\
3 \cdot 21 \\
5\end{array}$ & 4 & $\begin{array}{l}6 \\
6 \\
6\end{array}$ & $\begin{array}{r}10 \\
9\end{array}$ & 23 \\
\hline Sixpences & $\left\{\begin{array}{l}1816 \\
1817 \\
1820 \\
1821 \\
1824 \\
1825\end{array}\right\}$ & $\begin{array}{l}300 \\
300 \\
300\end{array}$ & $\begin{array}{l}2 \\
2\end{array}$ & 3 & 5 & 10 & $\begin{array}{l}3 \cdot 39 \\
3 \cdot 21 \\
5\end{array}$ & 2 & 3 & $\begin{array}{l}5 \\
4\end{array}$ & 23 \\
\hline
\end{tabular}


1, A.

December, 1826.

silver moneys coined since 1816, with a view to ascertain the amount of the said coins.

gold and silver coins in circulation since the year 1816, the following of pieces of each denomination of coin.

\begin{tabular}{|c|c|c|c|c|c|c|c|c|c|c|c|}
\hline \multicolumn{4}{|c|}{ Weight before washing. } & \multirow{2}{*}{\begin{tabular}{|r}
$\begin{array}{r}\text { Dirt } \\
\text { ontht } \\
\text { coin. }\end{array}$ \\
grs. \\
7 \\
15 \\
8
\end{tabular}} & \multicolumn{4}{|c|}{ Weight after washing. } & \multirow{2}{*}{$\begin{array}{c}\text { Loss of } \\
\text { weight. } \\
\text { grs. } \\
97 \cdot 5 \\
121 \\
40.5\end{array}$} & Equal per $100 l$. & $\begin{array}{c}\text { Charge of coinage } \\
\text { per } 100 l \text {. }\end{array}$ \\
\hline $\begin{array}{r}\text { lbs. } \\
7 \\
10 \\
10\end{array}$ & $\begin{array}{r}\text { oz. } \\
5 \\
8 \\
8\end{array}$ & $\begin{array}{r}\text { dwts. } \\
12 \\
3 \\
6\end{array}$ & $\begin{array}{r}\text { grs. } \\
20 \\
2 \\
\ldots\end{array}$ & & $\begin{array}{r}\text { lbs. } \\
7 \\
10 \\
10\end{array}$ & $\begin{array}{r}\text { oz. } \\
5 \\
8 \\
8\end{array}$ & $\begin{array}{r}\text { dwts. } \\
12 \\
2 \\
5\end{array}$ & $\begin{array}{l}\text { grs. } \\
13 \\
11 \\
16\end{array}$ & & $\begin{array}{rr}l . & 8 . \\
4 & 6.232 \\
3 & 11 \cdot 112 \\
1 & 3 \cdot 769\end{array}$ & $\begin{cases}8 . & d . \\
14 & 3 \cdot 749\end{cases}$ \\
\hline $\begin{array}{l}3 \\
\mathbf{2}\end{array}$ & $\begin{array}{l}2 \\
5\end{array}$ & $\begin{array}{l}8 \\
9\end{array}$ & $\begin{array}{l}8 \\
8\end{array}$ & $\begin{array}{l}6 \\
8\end{array}$ & $\begin{array}{l}3 \\
2\end{array}$ & $\begin{array}{l}\mathbf{2} \\
\mathbf{5}\end{array}$ & $\begin{array}{l}8 \\
9\end{array}$ & $\begin{array}{l}2 \\
\ldots\end{array}$ & $\begin{array}{l}52 \\
\mathbf{3 8}\end{array}$ & $\begin{array}{ll}5 & 7 \cdot 476 \\
5 & 4 \cdot 328\end{array}$ & \\
\hline 3 & 2 & 9 & 16 & 7 & 3 & 2 & 9 & 9 & 26 & 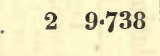 & \\
\hline 11 & 2 & 19 & 12 & 22 & 11 & 2 & 18 & 14 & 650 & $1910 \cdot 332$ & \\
\hline 11 & 3 & 6 & 2 & 29 & 11 & 3 & 4 & 21 & 501 & $15 \quad 3 \cdot 700$ & $44 \quad 9 \cdot 87$ \\
\hline 11 & 4 & 1 & 22 & 22 & 11 & 4 & 1 & .. & 46 & $14 \cdot 865$ & \\
\hline 4 & 5 & 5 & 18 & 14 & 4 & 5 & 5 & 4 & 602 & $\begin{array}{lll}2 & 5 & 11.832\end{array}$ & $\because$ \\
\hline 4 & 5 & 13 & 16 & 22 & 4 & 5 & 12 & 18 & 421 & $\begin{array}{lll}1 & 12 & 1.915\end{array}$ & $\begin{array}{rr}56 & 9.818\end{array}$ \\
\hline 4 & 6 & 7 & 20 & 13 & 4 & 6 & 7 & 7 & 64 & $410 \cdot 656$ & \\
\hline 2 & 2 & 5 & - & 10 & 2 & 2 & 4 & 14 & 493 & $\begin{array}{lll}3 & 15 & 3 \cdot 832\end{array}$ & \\
\hline 2 & 2 & 12 & 12 & 9 & 2 & 2 & 12 & 3 & 312 & $\begin{array}{lll}2 & 7 & 8\end{array}$ & $\begin{array}{ll}65 & 7 \cdot 878\end{array}$ \\
\hline 2 & 3 & 3 & 12 & 12 & 2 & 3 & 3 & .. & 47 & $72 \cdot 165$ & \\
\hline
\end{tabular}

(Signed)

JOHN BARTON, Comptroller. 


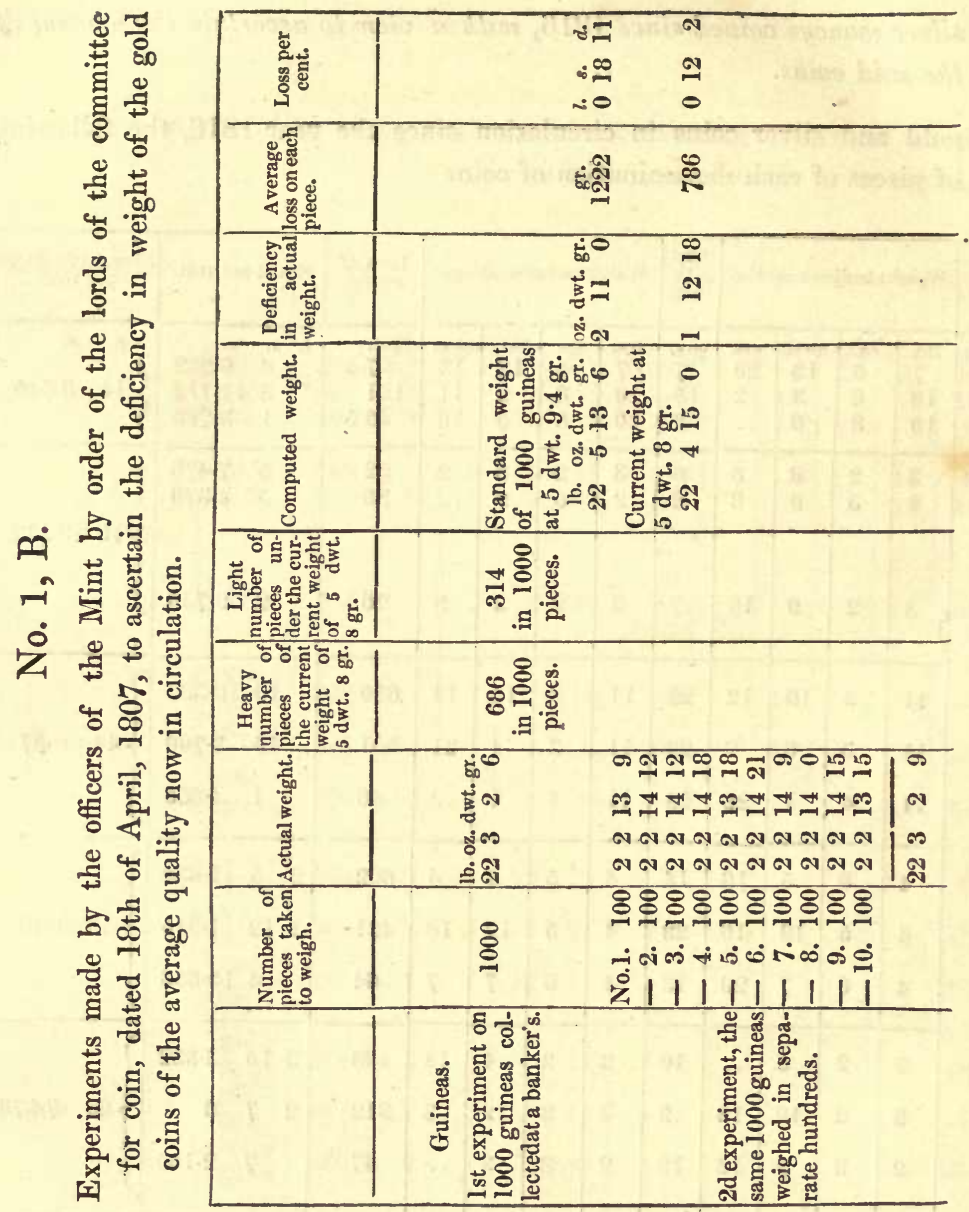




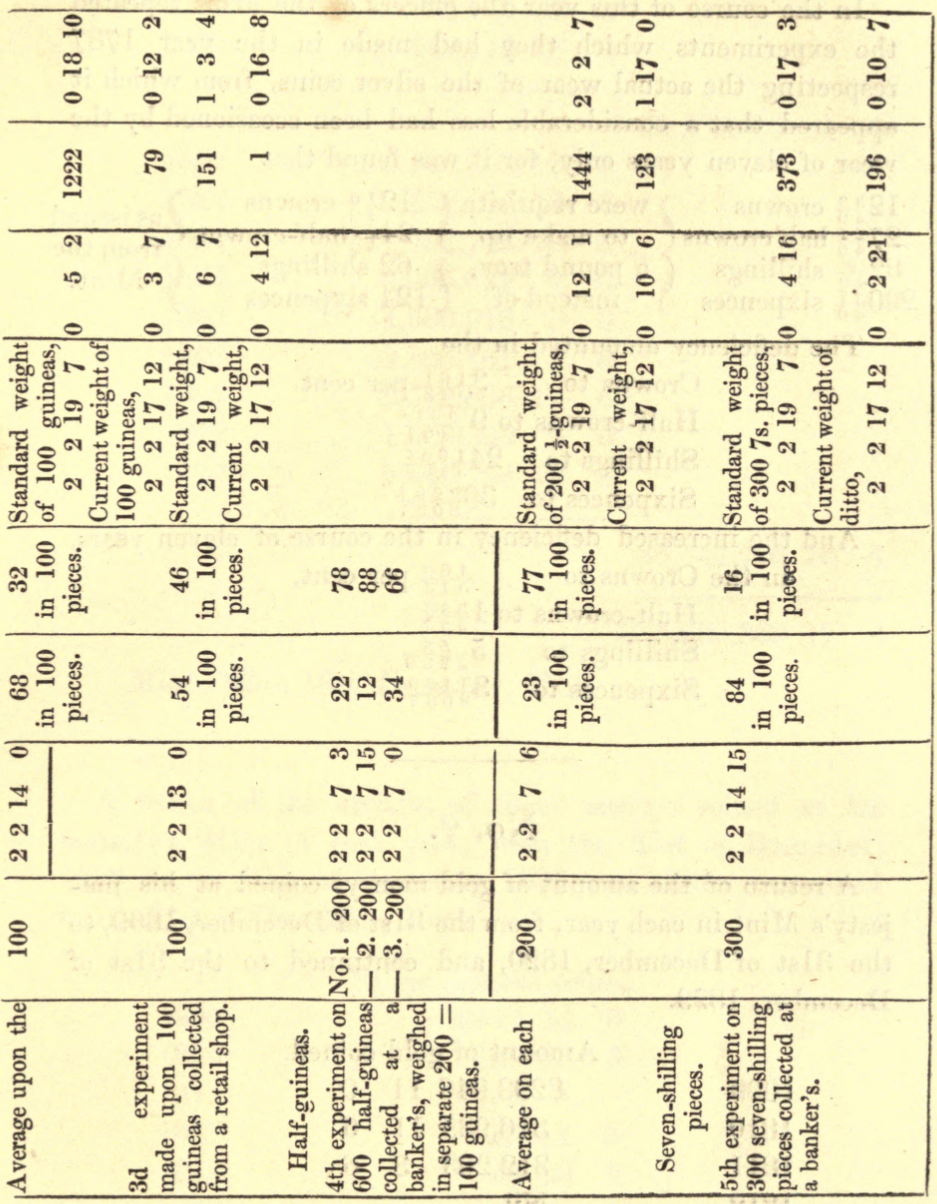




\section{No. 1, C.}

1798.

In the course of this year the officers of the Mint repeated the experiments which they had made in the year 1787 respecting the actual wear of the silver coins, from which it appeared that a considerable loss had been occasioned by the wear of eleven years only, for it was found that

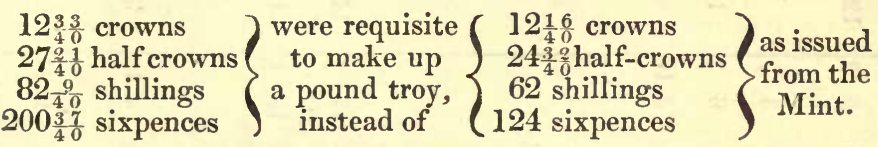

The deficiency amounted in the

Crowns to $\quad 3 \frac{16}{513}$ per cent.

Half-crowns to $9_{\text {T191 }}^{991}$

Shillings to $24 \frac{1964}{3} \frac{64}{80}$

Sixpences to $38 \frac{2}{8037}$

And the increased deficiency in the course of eleven years, in the Crowns to $\frac{100}{513}$ per cent.

Half-crowns to $1 \frac{3}{3} \frac{3}{6} \frac{3}{7}$

Shillings to $5 \frac{55}{3289}$

Sixpences to $3 \frac{11}{80} \frac{89}{37}$

\section{No. 2.}

A return of the amount of gold moneys coined at his majesty's Mint in each year, from the 31st of December, 1809, to the 31st of December, 1820, and continued to the 31st of December, 1829.

Amount of gold coined.

1809

1810

1811

1812

1813

1814

1815

1816
$£ 298,94611 \quad 0$

$\begin{array}{llll}316,935 & 11 & 6\end{array}$

$\begin{array}{lll}312,263 & 3 & 6\end{array}$

Nil.

$\begin{array}{lll}519,722 & 3 \quad 6\end{array}$

Nil.

Nil.

Nil. 


\begin{tabular}{lrrrr} 
& \multicolumn{4}{c}{ Amount of gold coined } \\
1817 & $4,275,337$ & 10 & 0 \\
1818 & $2,862,373$ & 10 & 0 \\
1819 & 3,574 & 10 & 8 \\
1820 & 949,516 & 10 & 0 \\
& & & & \\
& & & \\
1821 & $9,520,758$ & 13 & 10 \\
1822 & $5,356,787$ & 12 & 6 \\
1823 & 759,748 & 10 & 0 \\
1824 & $4,065,075$ & 0 & 0 \\
1825 & $4,580,919$ & 0 & 0 \\
1826 & $5,896,461$ & 7 & 6 \\
1827 & $2,512,636$ & 17 & 6 \\
1828 & $1,008,559$ & 2 & 6 \\
1829 & $2,446,754$ & 12 & 6
\end{tabular}

$36,147,700 \quad 16 \quad 4$

$\mathfrak{\& 4 5 , 6 8 6 , 3 6 9 \quad 1 7 \quad 4}$

Mint-Office, 18th December, 1830.

A return of the amount of silver moneys coined at his majesty's Mint in each year, from the 31st of December, 1809 , to the 31 st of December, 1820, and thence continued to the 31st of December, 1829.

Silver moneys coined.

1809 $\$ 11414 \quad 0$

1810

1811

$120 \quad 18 \quad 0$

Nil.

1812

$\begin{array}{lll}52 & 14 & 0\end{array}$

1813

$\begin{array}{lll}89 & 18 & 0\end{array}$

1814

1815

$\begin{array}{lll}161 & 4 & 0\end{array}$

1816

Nil.

$\mathfrak{L 9 , 5 3 8 , 6 6 9 \quad 1 \quad 0}$

1817

1818

$\begin{array}{rrr}52 & 14 & 0 \\ 89 & 18 & 0 \\ 161 & 4 & 0 \\ \text { Nil. } & & \\ 1,805,241 & 0 & 0 \\ 2,436,297 & 12 & 0 \\ 576,279 & 0 & 0\end{array}$

VOL. II.

C C 
Silver moneys coined.

\begin{tabular}{lrrr}
1819 & $1,267,272$ & 12 & 0 \\
1820 & 847,717 & 4 & 0 \\
\cline { 2 - 4 } 1821 & 433,686 & 0 & 0 \\
1822 & 31,430 & 7 & 1 \\
1823 & 285,271 & 16 & 0 \\
1824 & 282,070 & 16 & 0 \\
1825 & 417,535 & 16 & 0 \\
1826 & 608,605 & 16 & 0 \\
1827 & 33,019 & 16 & 0 \\
1828 & 16,288 & 3 & 0 \\
1829 & 108,259 & 16 & 0
\end{tabular}

$£ 6,933,346 \quad 16 \quad 0$

\begin{tabular}{llll}
$2,216,168$ & 6 & 1 \\
\hline $\mathscr{2} 9,149,515$ & 2 & 1
\end{tabular}

Mint-Office, 18th December, 1830. 


\section{No. 3, A.}

An account of the several denominations of silver moneys coined since the commencement of the silver coinage in 1816, to the 31st December, 1829.

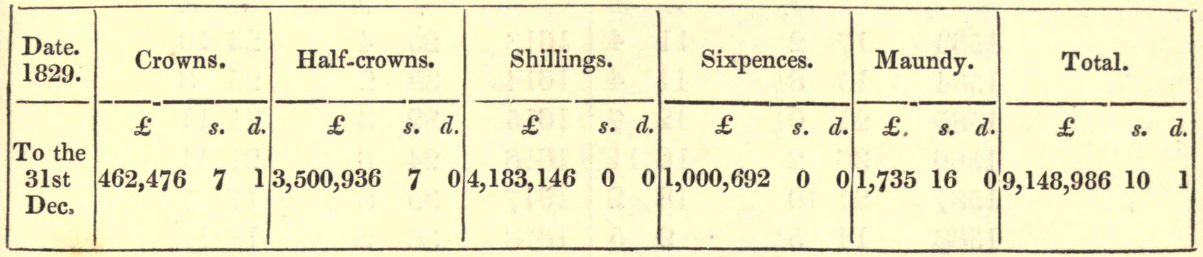

Mint-Office, 29th January, 1830.

\section{No. 3, B.}

An account of the several denominations of gold moneys coined since the commencement of the new gold coinage in 1817, to the 31st December, 1829.

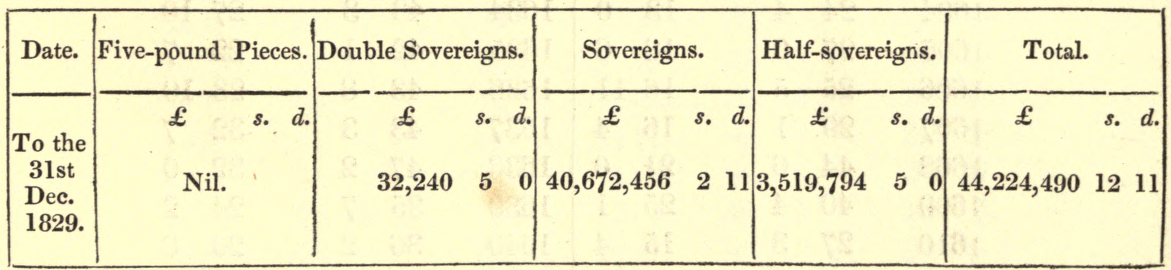

Mint-Office, 29th January, 1830. 
No. 4.

An account of the prices of wheat and malt per quarter at Oxford in each year, from 1583 to 1829 , by the Winchester bushel of eight gallons, being formed from an average of the highest and lowest prices of each year, taken at Ladyday and Michaelmas.

\begin{tabular}{|c|c|c|c|c|c|c|c|c|c|}
\hline Year. & & eat. & $\mathrm{Ma}$ & & Year. & Wh & & & alt. \\
\hline & $s$. & $d$. & & $d$. & & & $d$. & & \\
\hline 1583 & 17 & 2 & 11 & 4 & 1613 & 25 & 4 & 231 & 10 \\
\hline 1584 & 15 & $8 \frac{1}{2}$ & 11 & 4 & 1614 & 39 & 2 & 25 & 8 \\
\hline 1585 & 21 & $0 \frac{1}{2}$ & 12 & 7 & 1615 & 32 & 3 & 211 & 11 \\
\hline 1586 & 36 & 2 & 161 & 11 & 1616 & 24 & 8 & $\begin{array}{lll}21 & 1\end{array}$ & 11 \\
\hline 1587 & 27 & & 18 & 2 & 1617 & 39 & 8 & 17 & 7 \\
\hline 1588 & 14 & $5 \frac{1}{2}$ & 9 & 5 & 1618 & 38 & 2 & 181 & \\
\hline 1589 & 19 & 7 & 12 & 5 & 1619 & 30 & 10 & 17 & 7 \\
\hline 1590 & 23 & 1 & 16 & 4 & 1620 & 26 & 4 & 15 & 8 \\
\hline 1591 & 20 & 2 & 17 & 6 & 1621 & 25 & 9 & 13 & 1 \\
\hline 1592 & 16 & 7 & 11 & 4 & 1622 & 47 & 1 & 21 & 7 \\
\hline 1593 & 18 & $4 \frac{1}{2}$ & 11 & 3 & 1623 & 45 & 8 & 26 & 0 \\
\hline 1594 & 32 & 0 & 16 & 4 & 1624 & 38 & 6 & 19 & 9 \\
\hline 1595 & 38 & 6 & 22 & 7 & 1625 & 41 & 2 & 18 & 6 \\
\hline 1596 & 46 & 3 & 24 & 5 & 1626 & 39 & 5 & 24 & 9 \\
\hline 1597 & 56 & 10 & 35 & 2 & 1627 & 30 & 6 & 17 & 7 \\
\hline 1598 & 37 & & 50 & 2 & 1628 & 25 & 5 & 13 & 2 \\
\hline 1599 & 23 & 8 & 14 & 5 & 1629 & 34 & 8 & 141 & 11 \\
\hline 1600 & 29 & 0 & 161 & 1 & 1630 & 45 & 7 & 28 & 5 \\
\hline 1601 & 26 & 8 & 19 & 5 & 1631 & 52 & 2 & 31 & 4 \\
\hline 1602 & 24 & 3 & 14 & 5 & 1632 & 37 & 4 & 21 & 4 \\
\hline 1603 & 26 & 8 & 12 & 7 & 1633 & 43 & 10 & 24 & 9 \\
\hline 1604 & 24 & 4 & 13 & 0 & 1634 & 43 & 3 & 271 & 10 \\
\hline 1605 & 27 & 0 & 18 & 6 & 1635 & 42 & 1 & 22 & 7 \\
\hline 1606 & 25 & 5 & 161 & 11 & 1636 & 43 & 8 & 231 & 10 \\
\hline 1607 & 29 & 1 & 16 & 4 & 1637 & 43 & 3 & 32 & 7 \\
\hline 1608 & 44 & 6 & 21 & 0 & 1638 & 47 & 2 & 32 & 0 \\
\hline 1609 & 40 & 4 & 25 & 1 & 1639 & 35 & 7 & 24 & 2 \\
\hline 1610 & 27 & 3 & 15 & 4 & 1640 & 36 & 2 & 20 & 8 \\
\hline 1611 & 30 & 3 & 161 & & 1641 & 40 & 9 & 21 & 4 \\
\hline 1612 & 24 & 0 & 22 & 7 & 1642 & 32 & 9 & 23 & 2 \\
\hline
\end{tabular}




\begin{tabular}{|c|c|c|c|c|c|c|c|c|c|c|}
\hline Year. & Wh & eat. & & Mal & & Year. & Wh & eat. & & alt. \\
\hline & s. & $d$. & & & d. & & s. & d. & s. & $d$. \\
\hline 1643 & 40 & 9 & & 181 & 10 & 1680 & 35 & 3 & 18 & 10 \\
\hline 1644 & 33 & 2 & v & 181 & 10 & 1681 & 39 & 1 & 21 & 2 \\
\hline 1645 & 38 & 6 & & 22 & 7 & 1682 & 35 & 3 & 24 & 6 \\
\hline 1646 & 45 & 7 & & 25 & 0 & 1683 & 35 & 3 & 25 & 9 \\
\hline 1647 & 58 & 1 & & 31 & 5 & 1684 & 36 & 8 & 23 & 8 \\
\hline 1648 & 59 & 3 & & 38 & 3 & 1685 & 43 & 8 & 25 & 1 \\
\hline 1649 & 62 & 6 & & 32 & 0 & 1686 & 26 & 8 & 20 & 8 \\
\hline 1650 & 54 & 6 & & 31 & 8 & 1687 & 27 & 7 & 22 & 7 \\
\hline 1651 & 49 & 5 & & 22 & 7 & 1688 & 23 & 2 & 18 & 10 \\
\hline 1652 & 36 & 10 & & & 7 & 1689 & 28 & 2 & 17 & 3 \\
\hline 1653 & 26 & 1 & & 21 & 4 & 1690 & 27 & 6 & 15 & 4 \\
\hline 1654 & 19 & 10 & & 15 & 7 & 1691 & 29 & 11 & 14 & 5 \\
\hline 1655 & 27 & 10 & & 161 & 11 & 1692 & 39 & 7 & 19 & 5 \\
\hline 1656 & 35 & 7 & & 20 & 2 & 1693 & 56 & 3 & 27 & 10 \\
\hline 1657 & 38 & 5 & & 23 & 0 & 1694 & 50 & 11 & 28 & l \\
\hline 1658 & 51 & 1 & & 25 & 8 & 1695 & 43 & 10 & 21 & 11 \\
\hline 1659 & 53 & 1 & & 31 & 4 & 1696 & 47 & 1 & 25 & 8 \\
\hline 1660 & 46 & 6 & & & 2 & 1697 & 53 & 10 & 24 & 8 \\
\hline 1661 & 55 & 1 & & 23 & 2 & 1698 & 58 & 1 & 28 & 10 \\
\hline 1662 & 62 & 1 & & 33 & 3 & 1699 & 56 & 3 & 34 & 8 \\
\hline 1663 & 43 & 3 & & 24 & 6 & 1700 & 34 & 9 & 25 & 4 \\
\hline 1664 & 40 & 11 & & 23 & 6 & 1701 & 27 & 5 & 22 & 7 \\
\hline 1665 & 38 & 3 & & 20 & 8 & 1702 & 24 & 6 & 19 & 0 \\
\hline 1666 & 27 & 6 & & 181 & 10 & 1703 & 28 & 5 & 17 & 5 \\
\hline 1667 & 29 & 7 & & 18 & 2 & 1704 & 35 & 6 & 22 & 7 \\
\hline 1668 & 18 & 3 & & 20 & 8 & 1705 & 26 & 1 & 17 & 10 \\
\hline 1669 & 39 & 0 & & 22 & 7 & 1706 & 22 & 6 & 18 & 10 \\
\hline 1670 & 34 & 11 & & 20 & 8 & 1707 & 23 & 1 & 20 & 5 \\
\hline 1671 & 34 & 1 & & 20 & 1 & 1708 & 32 & 10 & 24 & 5 \\
\hline 1672 & 29 & 4 & & 19 & 5 & 1709 & 61 & 8 & 29 & 5 \\
\hline 1673 & 43 & 10 & & & 9 & 1710 & 61 & 10 & 32 & 0 \\
\hline 1674 & 61 & 4 & & 16 & 4 & 1711 & 45 & 7 & 28 & 3 \\
\hline 1675 & 45 & 1 & & 26 & 7 & 1712 & 38 & 6 & 24 & 6 \\
\hline 1676 & 29 & 0 & & 19 & 9 & 1713 & 40 & 7 & 19 & 7 \\
\hline 1677 & 25 & 3 & & 221 & 11 & 1714 & 43 & 10 & 24 & 0 \\
\hline 1678 & 47 & 2 & & 231 & 10 & 1715 & 35 & 10 & 25 & 1 \\
\hline 1679 & 44 & 9 & & 22 & 7 & 1716 & 42 & 4 & 21 & 4 \\
\hline
\end{tabular}


Year. Wheat.

$\begin{array}{lll}1717 & 37 & 4\end{array}$

$\begin{array}{lll}1718 & 31 & 1\end{array}$

$1719 \quad 30 \quad 10$

$1720 \quad 28 \quad 5$

$1721 \quad 297$

$\begin{array}{lll}1722 & 29 & 1\end{array}$

$\begin{array}{lll}1723 & 28 & 5\end{array}$

$\begin{array}{lll}1724 & 30 & 2\end{array}$

$\begin{array}{lll}1725 & 37 & 5\end{array}$

$\begin{array}{lll}1726 & 42 & 2\end{array}$

$\begin{array}{lll}1727 & 36 & 2\end{array}$

$\begin{array}{lll}1728 & 50 & 0\end{array}$

$\begin{array}{lll}1729 & 46 & 1\end{array}$

$\begin{array}{lll}1730 & 31 & 5\end{array}$

$\begin{array}{lll}1731 & 24 & 0\end{array}$

$\begin{array}{lll}1732 & 22 & 2\end{array}$

$\begin{array}{lll}1733 & 23 & 4\end{array}$

$\begin{array}{lll}1734 & 30 & 2\end{array}$

$\begin{array}{lll}1735 & 35 & 6\end{array}$

$\begin{array}{lll}1736 & 37 & 4\end{array}$

$\begin{array}{lll}1737 & 35 & 8\end{array}$

$1738 \quad 27 \quad 10$

$\begin{array}{lll}1739 & 31 & 8\end{array}$

$\begin{array}{lll}1740 & 47 & 10\end{array}$

$\begin{array}{lll}1741 & 43 & 3\end{array}$

$\begin{array}{lll}1742 & 28 & 5\end{array}$

$1743 \quad 21 \quad 1$

$1744 \quad 217$

$1745 \quad 2111$

$\begin{array}{lll}1746 & 30 & 6\end{array}$

$1747 \quad 30 \quad 6$

$1748 \quad 29 \quad 2$

$1749 \quad 29 \quad 5$

$\begin{array}{lll}1750 & 28 & 8\end{array}$

$1751 \quad 3210$

$\begin{array}{lll}1752 & 35 & 7\end{array}$

$\begin{array}{lll}1753 & 37 & 9\end{array}$

199
Malt.

Year.

s. $d$.

205

193

$\begin{array}{ll}20 & 6\end{array}$

2611

236

$18 \quad 10$

245

230

$24 \quad 6$

2411

$30 \quad 1$

301

319

$\begin{array}{ll}20 & 1\end{array}$

199

1810

1810

1810

1810

227

$\begin{array}{ll}22 & 7\end{array}$

209

246

246

246

217

1611

1611

151

151

1810

208

199

199

\begin{tabular}{ll|l}
21 & 7 & 1789
\end{tabular}

\begin{tabular}{ll|l}
22 & 7 & 1790
\end{tabular}
Wheat.

s. d.

$1754 \quad 32 \quad 4$

2911

$\begin{array}{ll}38 & 2\end{array}$

605

$47 \quad 1$

$\begin{array}{ll}35 & 8\end{array}$

$\begin{array}{ll}26 & 2\end{array}$

245

2911

$\begin{array}{ll}33 & 1\end{array}$

$40 \quad 0$

$46 \quad 3$

4011

635

571

$44 \quad 5$

$49 \quad 9$

$\begin{array}{ll}49 & 8\end{array}$

$\begin{array}{lll}56 & 11\end{array}$

574

$62 \quad 2$

$57 \quad 8$

374

497

499

$\begin{array}{ll}34 & 8\end{array}$

374

534

$56 \quad 0$

$\begin{array}{ll}58 & 8\end{array}$

596

$48 \quad 5$

$41 \quad 10$

$49 \quad 9$

495

537

5710
Malt.

s. $d$.

218

208

209

$\begin{array}{ll}30 & 1\end{array}$

$\begin{array}{ll}28 & 2\end{array}$

217

1910

1611

208

$\begin{array}{ll}29 & 1\end{array}$

264

$26 \quad 4$

$27 \quad 3$

292

$27 \quad 2$

231

246

$30 \quad 1$

310

$\begin{array}{ll}34 & 8\end{array}$

3311

3311

264

246

264

246

227

227

282

359

$\begin{array}{lll}38 & 10\end{array}$

320

300

$30 \quad 1$

$28 \quad 3$

$28 \quad 3$

300 
APPENDIX.

Year. Wheat.

Malt. Year. Wheat. Malt.

$179151 \quad 6$

s. d.

s. $d . \quad$ s. $d$.

$1792 \quad 53 \quad 4$

320

1828

823

560

3410

1829

820

540

$1793 \quad 49 \quad 9$

$\begin{array}{ll}38 & 7\end{array}$

The prices of malt in-

$1794 \quad 49 \quad 5$

360

cludes the duty, which has

$\begin{array}{lll}1795 & 77 \quad 5\end{array}$

$40 \quad 5$

frequently varied, thus

415

1697

per bushel

06

3710

1760

additional

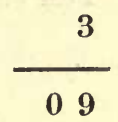

$1799 \quad 8811$

359

$\begin{array}{lll}1800 \quad 65 & 6\end{array}$

377

$65 \quad 11$

$1801 \quad 83 \quad 10$

$\begin{array}{lll}1802 & 69 & 3\end{array}$

$74 \quad 4$

$\begin{array}{ll}43 & 4\end{array}$

$\begin{array}{lll}1803 & 57 & 9\end{array}$

$\begin{array}{ll}31 & 8\end{array}$

$\begin{array}{lll}1804 & 92 & 0\end{array}$

335

$\begin{array}{lll}1805 & 106 & 0\end{array}$

$55 \quad 9$

$1806 \quad 84 \quad 5$

$1807 \quad 8511$

478

$\begin{array}{lll}50 & 10\end{array}$

$\begin{array}{lll}1808 \quad 90 & 6\end{array}$

$50 \quad 10$

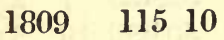

$\begin{array}{lll}1810 \quad 116 & 2\end{array}$

634

$\begin{array}{ll}65 & 3\end{array}$

$1811 \quad 112 \quad 0$

519

$\begin{array}{lll}1812 & 137 & 9\end{array}$

$\begin{array}{lll}1813 \quad 121 & 0\end{array}$

$1814 \quad 90 \quad 6$

729

$77 \quad 4$

$1815 \quad 75 \quad 0$

$\begin{array}{lll}1816 \quad 83 & 6\end{array}$

$\begin{array}{lll}1817 & 124 & 0\end{array}$

$\begin{array}{lll}1818 \quad 100 & 0\end{array}$

534

$\begin{array}{ll}42 & 8\end{array}$

454

734

754

$\begin{array}{lll}1819 & 85 & 0\end{array}$

$\begin{array}{lll}1820 & 73 & 0\end{array}$

$1821 \quad 78 \quad 0$

$\begin{array}{lll}1822 & 60 & 0\end{array}$

1823610

$1824 \quad 70 \quad 0$

$\begin{array}{ll}68 & 2\end{array}$

520

1792 the last $3 d$ re-

\begin{tabular}{cc} 
pealed & 03 \\
\cline { 2 - 3 } 1802 additional duty & $13 \frac{3}{4}$
\end{tabular}

$13 \frac{3}{4}$

177915 per cent. on three-pence

$17806 d$, and 5 per cent.

thereon, making the

wholeadditional duty 03

460

$48 \cdot 0$

480

540

$\begin{array}{lll}1825 & 72 & 0\end{array}$

600

$\begin{array}{lll}1826 & 63 & 6\end{array}$

560

$16 \frac{3}{4}$

1802 additional duty $10 \frac{1}{4}$

24

1803 war duty 20

-

44

1816 war duty ceased 20

$1827 \quad 610$

550

or two shillings and sevenpence per imperial bushel. 


\section{No. 5.}

Gross produce of the duty on gold and silver plate in Great Britain, from 1st August, 1784, to 5th January, 1800.

Year ended 1st Aug. 1785

1786

1787

1788

1789

1790

1791

1792

1793

1794

1795

1796 )

1797

1798

1799

1st August 1799

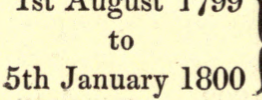

$\begin{array}{lll}\mathfrak{E} & s . & d .\end{array}$

$5,300 \quad 5 \quad 1$

$\begin{array}{llll}22,824 & 14 & 10 \frac{1}{2}\end{array}$

$\begin{array}{lll}25,617 & 3 & 9 \frac{3}{4}\end{array}$

$28,397 \quad 12 \quad 9$

$\begin{array}{lll}25,545 & 8 & 3_{4}^{3}\end{array}$

$26,681 \quad 11 \quad 5 \frac{1}{4}$

$\begin{array}{lll}29,085 & 8 & 4 \frac{3}{4}\end{array}$

$31,376 \quad 15 \quad 5$

$34,049 \quad 18 \quad 10 \frac{3}{4}$

Cannot be given.

$\begin{array}{lll}32,423 & 7 & 2 \frac{1}{2}\end{array}$

40,052 $18 \quad 5 \frac{1}{4}$

$\begin{array}{lll}4,079 & 15 \quad 2\end{array}$

$27,659 \quad 6 \quad 8 \frac{3}{4}$ 


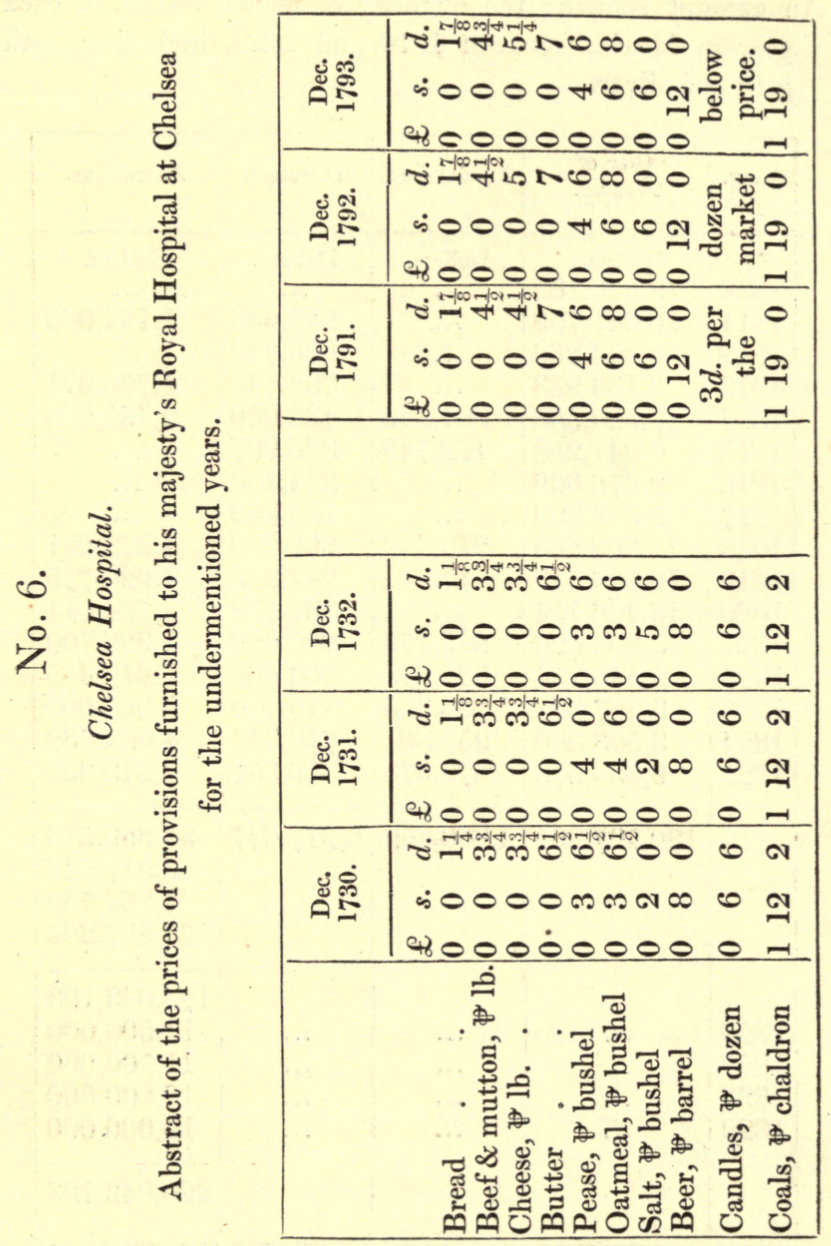


No. 7.

An account showing the quantity of money coined in each year in Mexico between 1810 and 1829, including both gold and silver.

\begin{tabular}{|c|c|c|c|c|}
\hline Year. & $\begin{array}{l}\text { City of } \\
\text { Mexico. }\end{array}$ & Guadalajara. & Durango. & Zaccatecas. \\
\hline 1810 & $\begin{array}{l}\text { Dollars. } \\
19,046,188\end{array}$ & $\begin{array}{c}\text { Dollars. } \\
\ldots .\end{array}$ & Dollars. & Dollars. \\
\hline 1811 & $10,041,796$ & $\ldots$ & 247,436 & $1,154,902$ \\
\hline 1812 & $4,409,266$ & $\ldots$ & 808,792 & \\
\hline 1813 & $6,133,983$ & & 784,240 & $4,776,971$ \\
\hline 1814 & $7,520,550$ & 901,949 & 438,050 & $2,455,000$ \\
\hline 1815 & $6,941,263$ & 192,749 & 336,987 & $\ldots$ \\
\hline 1816 & $9,276,009$ & .. & 314,193 & ... \\
\hline 1817 & $8,849,893$ & & 139,800 & \\
\hline 1818 & $11,386,288$ & 219,449 & 260,830 & $4,273,281$ \\
\hline 1819 & $12,030,515$ & $\ldots$ & 244,298 & $1,026,775$ \\
\hline 1820 & $10,406,154$ & $\ldots$ & 136,793 & 764,011 \\
\hline 1821 & $5,903,526$ & 255,174 & 209,229 & $1,326,700$ \\
\hline 1822 & $5,543,254$ & 931,645 & 608,666 & $3,610,455$ \\
\hline 1823 & $3,567,821$ & 734,355 & 818,430 & $3,965,000$ \\
\hline 1824 & $3,503,880$ & 957,365 & 753,345 & $4,093,062$ \\
\hline \multirow[t]{2}{*}{1825} & $6,036,878$ & 676,073 & 816,558 & $3,213,356$ \\
\hline & \multirow[t]{7}{*}{$130,597,264$} & \multirow[t]{2}{*}{$4,868,759$} & \multirow[t]{2}{*}{$6,917,647$} & $\begin{array}{r}30,659,513 \\
6,917,647 \\
4,868,759 \\
130,597,264\end{array}$ \\
\hline & & & & $173,043,183$ \\
\hline 1826 & & $\cdots$ & ... & $11,500,000$ \\
\hline 1827 & & ... & $\ldots$ & $11,500,000$ \\
\hline 1828 & & ... & $\cdots$ & $12,000,000$ \\
\hline \multirow[t]{2}{*}{1829} & & $\cdots$ & $\cdots$ & $12,000,000$ \\
\hline & & & & $220,043,183$ \\
\hline
\end{tabular}




\section{No. 8.}

\section{Quintos of Brazil.}

Product of the tax Quinto or the fifth of the gold from Minas Geras in Brazil, for each year, from 1752 to 1795, in periods of six years.

\begin{tabular}{|c|c|c|c|c|c|}
\hline Years. & Arobas. & Marcs. & Ounces. & Ottavas. & Grains. \\
\hline $\begin{array}{c}1752 \\
\text { to }\end{array}$ & & & & & \\
\hline $\begin{array}{l}1757 \\
1758\end{array}$ & 059 & $\cdots$ & 1 & $\ldots$ & 32 \\
\hline $\begin{array}{c}\text { to } \\
1765\end{array}$ & 611 & 58 & 5 & 4 & ${ }^{2} 14$ \\
\hline $\begin{array}{c}1766 \\
\text { to }\end{array}$ & 512 & 22 & 7 & 6 & 1 \\
\hline $\begin{array}{l}1771 \\
1772\end{array}$ & & & & & \\
\hline $\begin{array}{c}\text { to } \\
1777\end{array}$ & 448 & 12 & 1 & 3 & 62 \\
\hline $\begin{array}{c}1778 \\
\text { to }\end{array}$ & 396 & 4 & 6 & 7 & 57 \\
\hline $\begin{array}{l}1783 \\
1784\end{array}$ & & & & & \\
\hline $\begin{array}{c}\text { to } \\
1789\end{array}$ & 274 & 52 & $\ldots$ & 3 & 7 \\
\hline 1790 & & & & & \\
\hline $\begin{array}{c}\text { to } \\
1795\end{array}$ & 268 & 47 & 4 & 6 & 55 \\
\hline
\end{tabular}

In the Portuguese numeration, 72 grains make 1 ottava, 8 ottavas 1 ounce, 8 ounces 1 marc, and 64 marks 1 aroba. The Portuguese grain is to the English grain as 83 to 108 . The Portuguese aroba is $39 \frac{2}{5} \frac{0}{7} \frac{5}{6}$, or nearly $39 \frac{1}{2}$ pounds troy, and the value of it in sterling money is $£ 182117 \mathrm{~s} .4 \mathrm{~d}$.

See Appendix, No.22, to the report of the Bullion Committee of 1810. 


\section{No. 9.}

\section{Lavras in Minas Geras.}

An account showing the number of lavras (washings), miners, and labourers in the province of Minas Geras; and also the product of gold in that province on the average of the two years 1812 and 1813.

\begin{tabular}{|c|c|c|c|c|c|c|}
\hline Districts. & 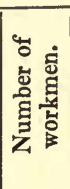 & 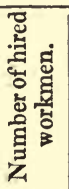 & 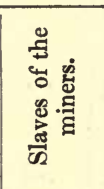 & 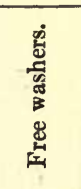 & 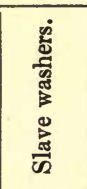 & 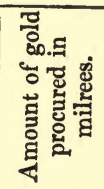 \\
\hline Villa Rica & 67 & 23 & 3,457 & 479 & 315 & 40,722 \\
\hline Santa Mariana & 126 & 44 & 1,886 & 600 & 591 & 50,056 \\
\hline St. Joas del Rei . & 31 & 27 & 362 & & 3 & 6,272 \\
\hline St. Joze . & 34 & 7 & 307 & 46 & 8 & 5,760 \\
\hline Barbacena & 12 & 11 & 77 & 122 & 154 & 4,343 \\
\hline Sahará . & 55 & 25 & 757 & 457 & 143 & 35,355 \\
\hline Villa Nova da Rai- & & & & & & \\
\hline & 95 & 33 & 1,813 & 801 & 385 & 86,986 \\
\hline Peracatu : . & 17 & 7 & 141 & 139 & 60 & 7,866 \\
\hline Villa do Principe & 15 & 23 & 317 & 120 & 393 & 8,394 \\
\hline Serro do Frio & 74 & 81 & 288 & 159 & 42 & 12,741 \\
\hline Campanha da Prina & 50 & 5 & 788 & 3 & 22 & 23,693 \\
\hline Minas Novas . & 8 & 2 & 60 & 20 & 22 & 986 \\
\hline \multirow[t]{2}{*}{ Pilangui · } & 47 & 47 & 350 & 345 & 10 & 26,910 \\
\hline & 631 & 335 & 10,603 & 3,291 & 2,148 & 310,084 \\
\hline
\end{tabular}

The value of the millrees; which was formerly between six and seven shillings, has gradually declined since the introduction of a paper currency in Brazil, till at present it can only be estimated at about two-thirds; but as the effect of the paper system had only begun to show itself in 1813, the millrees may be valued then at five shillings. 


\section{No. 10 . \\ Russian Gold and Silver.}

The produce of gold in Russia seems to have taken its first great step in the path of improvement in the year 1823 ; since which the increase appears to have been regular.

One official account states the amount of silver and gold to have been as follows:-

\begin{tabular}{lrr}
$\quad$ Years. & $\begin{array}{r}\text { Gold. } \\
\text { poods. }\end{array}$ & \multicolumn{1}{c}{$\begin{array}{c}\text { Silver. } \\
\text { poods. }\end{array}$} \\
1704 to 1810 & 1,726 & 61,859 \\
1811 to 1822 & 2,910 & 12,104 \\
1823 & 243 & 996 \\
1824 & 207 & 3,001 \\
1825 to 1828 & 1,037 & 11,904
\end{tabular}

According to another account from the department of finance, inserted in the Journal de Commerce of 4-16 April, 1831, the quantity of gold and platina produced from the Ural mountains has been,

\begin{tabular}{|c|c|c|c|c|}
\hline \multirow{3}{*}{$\begin{array}{l}\text { Year. } \\
1821\end{array}$} & \multicolumn{2}{|c|}{ Gold. } & \multicolumn{2}{|c|}{ Platina. } \\
\hline & pood & lbs. & & lbs. \\
\hline & 27 & 3 & & \\
\hline 1822 & 28 & 29 & & \\
\hline 1823 & 105 & 38 & & \\
\hline 1824 & 206 & 31 & 1 & 35 \\
\hline 1825 & 237 & 22 & 11 & 20 \\
\hline 1826 & 231 & 39 & 13 & 20 \\
\hline 1827 & 282 & 0 & 25 & 30 \\
\hline 1828 & 291 & 3 & 93 & 33 \\
\hline 1829 & 287 & 30 & 78 & 31 \\
\hline 1830 & 355 & 0 & 105 & 1 \\
\hline
\end{tabular}

The following statement is taken from the journals of the mines, commencing lst July, 1825, and ending at the middle of the year 1829, showing the proportion between the gold extracted by individuals, and that by the government :- 
Private persons.

poods. lbs. zolot.

1825 First six months Second six months

1826 First six months Second six months

1827 First six months

Second six months

$\begin{array}{lll}88 & 18 & 66\end{array}$

$\begin{array}{lll}83 & 8 & 66\end{array}$

$\begin{array}{lll}82 & 33 & 80\end{array}$

$\begin{array}{lll}78 & 29 & 10\end{array}$

$\begin{array}{lll}92 & 24 & 73\end{array}$

$\begin{array}{lll}99 & 25 & 72\end{array}$

$\begin{array}{lllll}1828 & \text { First six months } & 111 & 10 & 67\end{array}$

Second six months $92 \quad 5 \quad 47$

1829 First six months $\quad 95 \quad 34 \quad 46$
Government.

poods. lbs. zolot.

$\begin{array}{lll}35 & 21 & 46\end{array}$

$\begin{array}{lll}25 & 4 & 3\end{array}$

$\begin{array}{lll}37 & 14 & 6\end{array}$

$\begin{array}{lll}32 & 27 & 19\end{array}$

$\begin{array}{lll}48 & 3 & 34\end{array}$

$\begin{array}{lll}41 & 26 & 18\end{array}$

$\begin{array}{lll}45 & 16 & 8\end{array}$

$\begin{array}{lll}42 & 10 & 53\end{array}$

$\begin{array}{lll}46 & 8 & 0\end{array}$

The following statement from the Journal de Commerce shows the contrast between the products of 1829 and 1830 :-

1829.

poods. lbs.

Gold from the mines of the crown $108 \quad 9$

Gold from the mines of individuals $187 \quad 21$
1830. poods. lbs. $150 \quad 22$ $204 \quad 17$

The Russian pood is divided into forty pounds, and the pound into ninety-six zolotnicks. The Russian pood is equal to thirty-six pounds avoirdupois, or forty-five pounds troy.

\author{
No. 11. \\ Extract of a Letter from M. de C-.
}

Geneva, 14th Nov. 1830.

MY DEAR SIR,

Since my return to Switzerland, I have not forgotten the questions you put to me about the quantity of gold and silver used in our manufactures. I have tried to collect some positive information on the subject, and my answer has been delayed merely because I met with more considerable difficulties than I had expected. These arise partly from differences in the regulations respecting the stamp, in the three cantons 
(Geneva, Neufchatel, and Berne), where precious metals are worked, and partly from the manner in which these regulations are enforced. Government's stamp or mark, where it is required, is not considered as a taxation, but as a security for purchasers ; and in our town, for instance, it is not a compulsory measure, but every watchmaker or goldsmith is allowed to sell his work stamped or not as he likes. A very large number of watches or goldsmith's ware, which are smuggled into France, England, or other countries, are not marked. Official returns of these stamps are therefore of no use, and lead only to errors.

However, being particularly desirous of collecting some facts that may be acceptable to you, I consulted at Geneva a gentleman who is known to have paid, for many years, considerable attention to our commerce and manufactures; and at Neufchatel, another gentleman, a merchant, whom I know to be a very sensible and well-informed man. They have made some calculations for me which I consider as near the truth, particularly as I see how well they agree with the numbers given in Picot's Statistique de la Suisse, $2 d$ edit. 1830. The following are the accounts given to me :-

\section{1.-Consumption of Gold.}

Gold watches and jewellery are made chiefly at Geneva. From official returns, we know the total number of workshops and workmen. We know also from private inquiries the quantity of gold required every day for three of the largest manufactories, and combining these two documents, we suppose that the yearly consumption of gold at Geneva Ounces ' is about

A very small number of gold watches are manufactured at Neufchatel, but it cannot exceed .

75,000

Total consumption in Switzerland, not below 1,000 This is for the years 1829 and 1830 .

One ounce $=30_{\top} \mathbf{g 9}$ French metric system. 


\section{2.-Consumption of Silver.}

Silver watches are manufactured chiefly in the mountains of Neufchatel, and in a neighbouring part of the canton of Berne, called Val St. Junier. They export now every year 130,000 watches, the mean weight of the silver case being 18 deniers ${ }^{1}$; the total consumption of silver is

Ounces.

The consumption at Geneva is said by Picot to be 97,500 In the last few years a great many silver plates and 40,000 forks, which were formerly exported from Geneva, have been made at Berne. No mark is established by government in that town, and we have no means whatever of ascertaining the extent of this new trade; I suppose they melt as much silver as in Geneva, and perhaps much more, say

Total consumption not under

177,500

I believe that the first account (respecting gold) is more precise than this, because there must be in other towns, as Basle, Zurich, and Lausanne, some few goldsmiths, who make common works (forks, spoons, \&c. \&c.) for the consumption of those towns and not for exportation. I suspect the total consumption is not far from 200,000 ounces.

I will add some few observations which may perhaps be of use to you.

During the 16th century large manufactures of gold galloons and laces existed at Geneva, but this branch was gradually transferred to Lyons. At the same time watchmakers began to work at Geneva. The tirst was established in 1587, and the first regulations for that trade were made in 1600 . Since this period, the consumption of gold has increased until the year $\mathrm{J789}$; it then decreased rapidly in consequence of the French revolution, and of our forced union to France. It was gradually decaying, till our watchmakers began to make small watches for ladies. This gave an impulse to their trade, which, however, does not yield the same profit as in 1789 . The jeweller's trade has increased since that time; taking

124 deniers in one ounce. 
all together, the consumption of gold must be now not far from what it was in 1789, because if the number of watches and jewels is now inferior to what it was, they are also not so heavy as they were formerly.

At Neufchatel they only began to make watches at the end of the 17 th century. In the year 1780 they exported 40,000 watches, while they export now 130,000 , and have more chance of a regular increase than we at Geneva.

Our gold is supplied partly by ingots, and partly by coins of different countries. Silver is more generally taken from coin, I believe. Hardly any money is coined in Switzerland, where foreign monies circulate widely. We have only a very considerable quantity of low coin (inferior to the shilling) composed of mixed copper and silver. Comparing the population with that of England, I suppose we have about three times more of this little coin than in England. You are aware, I suppose, that a large quantity of Swiss watches and jewellery is smuggled into France, and they are there stamped and sold as French products, so that you can give no credit to the French official returns of the watches manufactured at Besançon or Paris.

$$
\text { No. } 12, \text { A. }
$$

Silver Watches at Birmingham.

Silver watch-cases assayed and marked at the Birmingham Assay Office (not charged with duty) from 26th March, 1798, to 14th April, 1831.

$\begin{array}{rrrr}\text { From 25th March, 1798, } & \text { to July, } & 1798 & 2,549 \\ \text { June, } 1798 & 1799 & 10,305 \\ 1799 & 1800 & 11,094 \\ 1800 & 1801 & 13,617 \\ 1801 & 1802 & 16,363 \\ 1802 & 1803 & 20,617 \\ 1803 & 1804 & 23,254 \\ 1804 & 1805 & 30,199 \\ 1805 & 1806 & 41,408 \\ 1806 & 1807 & 42,128\end{array}$




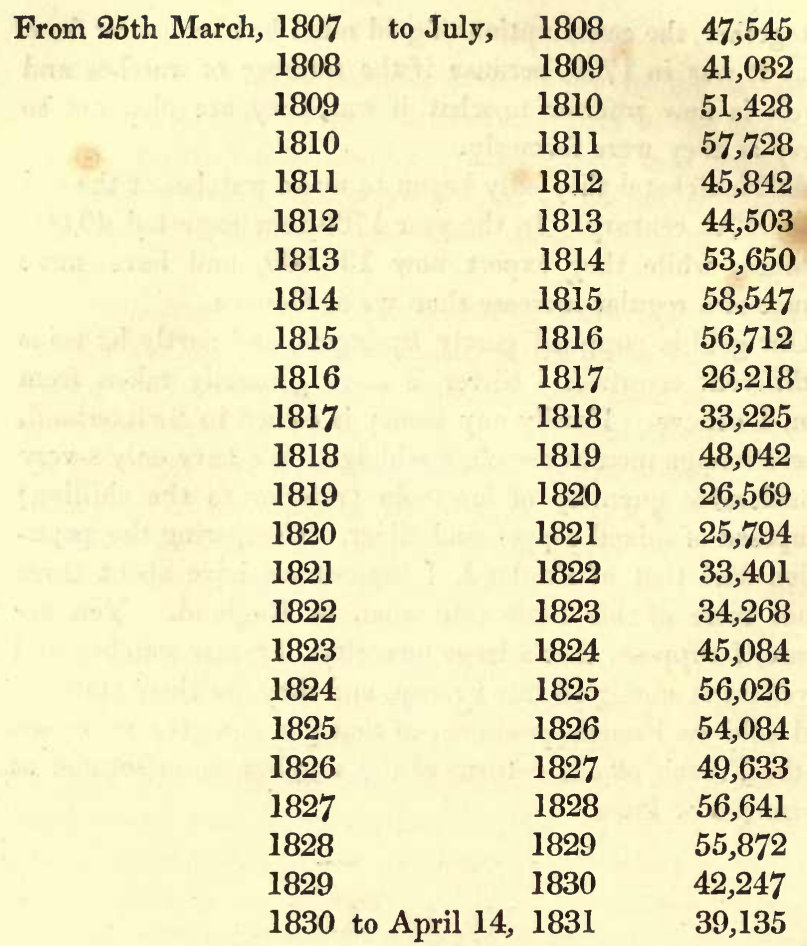

\section{No. $12, \mathrm{~B}$.}

Gold Watches at Birmingham.

Gold watch-cases assayed and marked at the Birmingham Assay Office (not charged with duty) up to the 14th April, 1831.

\begin{tabular}{|c|c|c|}
\hline From June, 1824 & to July, & 1825 \\
\hline 1825 & & 1826 \\
\hline 1826 & & 1827 \\
\hline 1827 & & 1828 \\
\hline 1828 & & 1829 \\
\hline 1829 & & 1830 \\
\hline 1830 & April 15, & 1831 \\
\hline
\end{tabular}




\section{No. 13.}

An account of the number of ounces of gold plate and of silver plate for which duty was paid in each year from 5 th January, 1799, to 5th January, 1830, and also an account showing the number of ounces for which the drawback was allowed in each of those years.

\begin{tabular}{|c|c|c|c|c|c|c|c|}
\hline \multirow{3}{*}{$\begin{array}{c}\text { Years ended } \\
\boldsymbol{5} \text { th } \mathbf{J} \text { an. }\end{array}$} & \multirow{2}{*}{\multicolumn{2}{|c|}{ Duty paid on. }} & \multirow{2}{*}{\multicolumn{2}{|c|}{ Drawbacks on. }} & \multicolumn{3}{|c|}{ Not distinguished. } \\
\hline & & & & & \multicolumn{2}{|c|}{ England. } & \multirow{2}{*}{ Ireland. } \\
\hline & $\begin{array}{l}\text { Gold } \\
\text { Plate. }\end{array}$ & $\begin{array}{l}\text { Silver } \\
\text { Plate. }\end{array}$ & $\begin{array}{l}\text { Gold } \\
\text { Plate. }\end{array}$ & $\begin{array}{l}\text { Silver } \\
\text { Plate. }\end{array}$ & $\begin{array}{c}\text { Duty on } \\
\text { Gold \& Silver. }\end{array}$ & $\begin{array}{l}\text { Drawbacks on } \\
\text { Gold \& Silver. }\end{array}$ & \\
\hline $\begin{array}{l}\quad 1800 \\
\text { Town ..... } \\
\text { Country ... } \\
\text { Scotland... } \\
\text { Ireland.... }\end{array}$ & 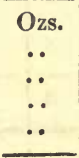 & $\begin{array}{c}\text { Ozs. } \\
\ldots \\
\cdots \\
\cdots \\
\cdots\end{array}$ & $\begin{array}{l}\text { Ozs. } \\
\ldots \\
\ldots \\
\ldots \\
\ldots\end{array}$ & $\left.\begin{array}{c}\text { Ozs. } \\
\ldots \\
\ldots \\
\cdots \\
\cdots\end{array}\right\}$ & $\begin{array}{ccc}£ . & 8 . & d . \\
23550 & 6 & 0 \\
610 & 16 & 8 \\
\cdots & \end{array}$ & $\begin{array}{ccc}£ . & \text { s. } & d . \\
3102 & 4 & 10 \\
6 & 1 & 11 \\
\ldots & \end{array}$ & $\begin{array}{l}\text { Ozs. } \\
- \\
-\end{array}$ \\
\hline & $\cdots$ & $\cdots$ & .. & .. & $24161 \quad 2 \quad 8$ & $\begin{array}{lll}1308 & 6 & 9\end{array}$ & - \\
\hline $\begin{array}{l}\text { Town....... } \\
\text { Country... } \\
\text { Scotland... } \\
\text { Ireland.... }\end{array}$ & $\begin{array}{c}5221 \\
\cdots \\
30\end{array}$ & $\begin{array}{c}864942 \\
\ldots \\
38024 \\
\ldots\end{array}$ & $\begin{array}{l}77 \\
\ldots \\
\cdots \\
\cdots\end{array}$ & $\begin{array}{c}142220 \\
\ldots \\
485 \\
.\end{array}$ & $\begin{array}{cc}4780 & 19 \\
\cdots & 3 \frac{1}{4} \\
\cdots & \end{array}$ & $\begin{array}{c}23 \ddot{14} 9 \\
\cdots\end{array}$ & $\bar{z}$ \\
\hline & 5251 & 902966 & 77 & 142705 & $\begin{array}{llll}4780 & 19 & 3 & \frac{1}{4}\end{array}$ & $\begin{array}{lll}23 & 14 & 9\end{array}$ & - \\
\hline $\begin{array}{l}\text { T812. } \\
\text { Town..... } \\
\text { Country.... } \\
\text { Scotland. . } \\
\text { Ireland.... }\end{array}$ & $\begin{array}{c}4605 \\
\dddot{14} \\
\ldots \\
\end{array}$ & $\begin{array}{c}888456 \\
3 \ddot{4} 66 \\
\ldots\end{array}$ & $\begin{array}{l}19 \\
\ldots \\
\cdots \\
\cdots\end{array}$ & $\begin{array}{c}113917 \\
\ldots \\
406 \\
\ldots \\
\end{array}$ & 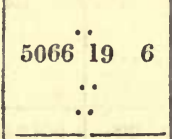 & $\begin{array}{c}57^{\circ} 0 \\
\cdots \\
\cdots\end{array}$ & $\bar{z}$ \\
\hline & 4619 & 925882 & 19 & 114323 & $\begin{array}{lll}5066 & 19 & 6\end{array}$ & $\begin{array}{lll}57 & 0 & 6\end{array}$ & - \\
\hline $\begin{array}{c}1803 . \\
\text { Town ...... } \\
\text { Country ... } \\
\text { Scotland ... } \\
\text { Ireland ... . }\end{array}$ & $\begin{array}{c}5118 \\
\ldots \\
\cdots \\
\end{array}$ & $\begin{array}{c}941028 \\
\ldots \\
45353 \\
\ldots \\
\end{array}$ & $\begin{array}{l}66 \\
\cdots \\
\cdots \\
\cdots \\
\end{array}$ & $\begin{array}{c}126783 \\
\cdots 95 \\
\ldots \\
\end{array}$ & $\begin{array}{cc}5437^{\circ} & 9 \\
\cdots & 8 \\
\cdots & \\
\end{array}$ & $\begin{array}{c}75 \ddot{11} 2 \\
\cdots \\
\cdots\end{array}$ & I \\
\hline & 5137 & 986381 & 66 & 126878 & $\begin{array}{lll}5437 & 9 & 8\end{array}$ & $\begin{array}{lll}75 & 11 & 2\end{array}$ & - \\
\hline $\begin{array}{l}1804 . \\
\text { Town ...... } \\
\text { Country ... } \\
\text { Scotland ... } \\
\text { Ireland ... . }\end{array}$ & $\begin{array}{c}5420 \\
\cdots \\
25 \\
\cdots\end{array}$ & $\begin{array}{c}999919 \\
\ldots \\
48950 \\
\ldots\end{array}$ & $\begin{array}{l}10 \\
\ldots \\
.\end{array}$ & $\begin{array}{c}99295 \\
\ldots \\
\therefore \\
. .\end{array}$ & $\begin{array}{c}6371 \ddot{13} 7 \\
\cdots \\
\cdots\end{array}$ & $\begin{array}{cc}162^{\cdots} & 4 \\
\cdots & \\
\cdots & \end{array}$ & z \\
\hline & 5445 & 1048869 & 10 & 99295 & $\begin{array}{lll}6371 & 13 \quad 7\end{array}$ & $\begin{array}{lll}162 & 4 & 0\end{array}$ & - \\
\hline
\end{tabular}




\begin{tabular}{|c|c|c|c|c|c|c|c|}
\hline \multirow{3}{*}{$\begin{array}{l}\text { Years ended } \\
5 \text { th Jan. }\end{array}$} & \multirow{2}{*}{\multicolumn{2}{|c|}{ Duty paid on. }} & \multirow{2}{*}{\multicolumn{2}{|c|}{ Drawbacks on. }} & \multicolumn{3}{|c|}{ Not distinguished. } \\
\hline & & & & & \multicolumn{2}{|c|}{ England. } & \multirow{2}{*}{$\frac{\text { Ireland. }}{\text { Duty. }}$} \\
\hline & $\begin{array}{l}\text { Gold } \\
\text { Plate. }\end{array}$ & $\begin{array}{l}\text { Silver } \\
\text { Plate. }\end{array}$ & $\begin{array}{l}\text { Gold } \\
\text { Plate. }\end{array}$ & $\begin{array}{l}\text { Silver } \\
\text { Plate. }\end{array}$ & $\begin{array}{c}\text { Duty on } \\
\text { Gold \& Silver. }\end{array}$ & $\begin{array}{l}\text { Drawbacks on } \\
\text { Gold \& Silver. }\end{array}$ & \\
\hline $\begin{array}{c}1805 . \\
\text { Town ...... }\end{array}$ & $\begin{array}{l}\text { Ozs. } \\
\mathbf{4 8 3 4}\end{array}$ & $\begin{array}{l}\text { Ozs. } \\
856010\end{array}$ & $\begin{array}{r}\text { Ozs. } \\
21\end{array}$ & $\begin{array}{l}\text { Ozs. } \\
114829\end{array}$ & $\begin{array}{lll}£ . & \text { s. } & d . \\
& . . & \end{array}$ & $\begin{array}{ccc}E . \quad \text { s. } & d . \\
\ldots & \end{array}$ & Ozs. \\
\hline $\begin{array}{l}\text { Country .... } \\
\text { Scotland... }\end{array}$ & $\ddot{2}_{0}$ & $\ddot{0}$ & . & . & $\begin{array}{lll}4469 & 10 & 0 \frac{1}{4}\end{array}$ & $\begin{array}{lll}49 & 0 & 3\end{array}$ & - \\
\hline Ireland ..... & 20 & 46778 & $\ddot{0}$ & 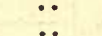 & 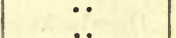 & $\ldots$ & - \\
\hline & & & & & & & \\
\hline & 4854 & 902788 & 21 & 114829 & $\begin{array}{llll}4469 & 10 & 0 \frac{1}{4}\end{array}$ & $\begin{array}{lll}49 & 0 & 3\end{array}$ & - \\
\hline $\begin{array}{l}1806 . \\
\text { Town..... } \\
\text { Country ... } \\
\text { Scotland... } \\
\text { Ireland.... }\end{array}$ & $\begin{array}{c}5382 \\
\cdots \\
26 \\
\cdots\end{array}$ & $\begin{array}{c}1005056 \\
\ddot{51637} \\
\ldots\end{array}$ & $\begin{array}{l}9 \\
\cdots \\
\cdots \\
\cdots\end{array}$ & $\begin{array}{c}122082 \\
\ldots \\
\ldots \\
\ldots\end{array}$ & $\begin{array}{cc}667415 & 8 \\
\cdots & \end{array}$ & $\begin{array}{c}40^{\circ} 9 \\
\cdots \\
\cdots\end{array}$ & E \\
\hline 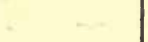 & 5408 & 1056693 & 9 & 122082 & $6674 \quad 15 \quad 8$ & $\begin{array}{lll}40 & 9 & 9\end{array}$ & - \\
\hline $\begin{array}{l}\text { 1807. } \\
\text { Town ..... } \\
\text { Country ... } \\
\text { Scotland ... } \\
\text { Ireland.... }\end{array}$ & $\begin{array}{c}5349 \\
\ldots \\
23 \\
\ldots \\
\end{array}$ & \begin{tabular}{c}
1026317 \\
\hdashline \\
58208 \\
$\ldots$ \\
\end{tabular} & $\begin{array}{l}43 \\
\cdots \\
\cdots \\
\cdots\end{array}$ & $\begin{array}{c}120613 \\
\ldots \\
995 \\
\end{array}$ & $\begin{array}{ccc}7205 & 14 & 1 \frac{1}{4} \\
\cdots & \\
\end{array}$ & $\begin{array}{ccc}39 & 2 & 9 \\
\cdots & \\
\cdots & \\
\end{array}$ & $\bar{z}$ \\
\hline & 5372 & 1084525 & 43 & 121608 & $\begin{array}{lll}7205 & 14 & 1 \frac{1}{4}\end{array}$ & $\begin{array}{lll}39 & 2 & 9\end{array}$ & 一 \\
\hline $\begin{array}{c}1808 . \\
\text { Town ...... } \\
\text { Country .... } \\
\text { Scotland ... } \\
\text { Ireland from } \\
\text { Aug. 11, } \\
1807 . . .\end{array}$ & $\begin{array}{c}6018 \\
\ddot{38}\end{array}$ & $\begin{array}{c}1083643 \\
\dot{58106} \\
\ldots\end{array}$ & $\begin{array}{l}20 \\
\cdots \\
\cdots \\
\cdots\end{array}$ & $\begin{array}{c}131507 \\
\ldots \\
343 \\
\ldots\end{array}$ & $\begin{array}{ccc}7228 & 19 & 1 \frac{1}{4} \\
\cdots & \end{array}$ & $\begin{array}{c}20^{\cdots} 5 \\
\ldots \\
\cdots\end{array}$ & $\begin{array}{l}- \\
- \\
43274\end{array}$ \\
\hline & 6056 & 1141749 & 20 & 131850 & $\begin{array}{lll}7228 & 19 & 14\end{array}$ & $\begin{array}{lll}20 & 5 & 6 \frac{1}{2}\end{array}$ & 43274 \\
\hline $\begin{array}{l}\text { 1809. } \\
\text { Town ...... } \\
\text { Country ... } \\
\text { Scotland ... } \\
\text { Ireland .... }\end{array}$ & $\begin{array}{c}6150 \\
39 \\
\cdots\end{array}$ & $\begin{array}{c}1101562 \\
\ddot{5} 7850 \\
\cdots\end{array}$ & $\begin{array}{l}18 \\
\cdots \\
\cdots \\
\cdots\end{array}$ & $\begin{array}{c}90335 \\
\ddot{181} \\
\cdots\end{array}$ & 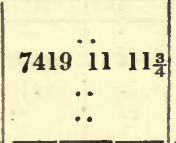 & $\begin{array}{c}1217 \\
\cdots\end{array}$ & $\frac{\bar{Z}}{136522}$ \\
\hline & 6189 & 1159412 & 18 & 90516 & $\begin{array}{llll}7419 & 11 & 11 & 1 \frac{8}{4}\end{array}$ & 12176 & 136522 \\
\hline $\begin{array}{l}1810 . \\
\text { Town ..... } \\
\text { Country ... } \\
\text { Scotland ... } \\
\text { Ireland.... }\end{array}$ & $\begin{array}{c}6345 \\
\cdots \\
\cdots\end{array}$ & $\begin{array}{c}1181996 \\
\ldots \\
60212 \\
\ldots\end{array}$ & $\begin{array}{l}53 \\
\cdots \\
\cdots \\
\cdots\end{array}$ & $\begin{array}{l}70763 \\
\cdots \\
353 \\
\cdots\end{array}$ & $\begin{array}{ccc}8573 & 6 & 4_{4}^{1} \\
\cdots & \\
\cdots & \end{array}$ & $\begin{array}{c}12{ }^{\cdots} 6 \\
\cdots\end{array}$ & $\frac{\bar{Z}}{147205}$ \\
\hline & 6382 & 1242208 & 53 & 71116 & $8573 \quad 6 \quad 4 \frac{1}{4}$ & $\begin{array}{lll}12 & 2 & 6\end{array}$ & 147205 \\
\hline
\end{tabular}




\begin{tabular}{|c|c|c|c|c|c|c|c|}
\hline & \multirow{2}{*}{\multicolumn{2}{|c|}{ Duty paid on. }} & \multirow{2}{*}{\multicolumn{2}{|c|}{ Drawbacks on. }} & \multicolumn{3}{|c|}{ Not distinguished. } \\
\hline \multirow{2}{*}{$\begin{array}{l}\text { Years ended } \\
5 \text { th Jan. }\end{array}$} & & & & & \multicolumn{2}{|c|}{ England. } & \multirow{2}{*}{$\frac{\text { Ireland. }}{\text { Duty. }}$} \\
\hline & $\begin{array}{l}\text { Gold } \\
\text { Plate. }\end{array}$ & $\begin{array}{l}\text { Silver } \\
\text { Plate. }\end{array}$ & $\begin{array}{l}\text { Gold } \\
\text { Plate. }\end{array}$ & $\begin{array}{l}\text { Silver } \\
\text { Plate. }\end{array}$ & $\begin{array}{c}\text { Duty on } \\
\text { Gold \& Silver. }\end{array}$ & $\begin{array}{l}\text { Drawbacks on } \\
\text { Gold \& Silver. }\end{array}$ & \\
\hline $\begin{array}{l}1811 . \\
\text { Town ..... } \\
\text { Country ... } \\
\text { Scotland ... } \\
\text { Ireland .... }\end{array}$ & $\begin{array}{c}\text { Ozs. } \\
7403 \\
\cdots \\
32 \\
\cdots\end{array}$ & $\begin{array}{c}\text { Ozs. } \\
1268636 \\
\ldots \\
72388 \\
\ldots\end{array}$ & $\begin{array}{l}\text { Ozs. } \\
102 \\
\ldots \\
\ldots \\
\cdots\end{array}$ & $\begin{array}{l}\text { Ozs. } \\
84232 \\
\ddot{2664} \\
\ldots\end{array}$ & $\begin{array}{ccc}£ . & \text { s. } & d . \\
& \ldots & \\
9893 & 5 & 7 \\
\ldots & & \\
\ldots & & \end{array}$ & 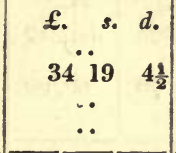 & $\frac{\text { Ozs. }}{\overline{-}}$ \\
\hline & 7435 & 1341024 & 102 & 86896 & $\begin{array}{lll}9893 & 5 & 7\end{array}$ & $\begin{array}{lll}34 & 19 & 4 \frac{1}{2}\end{array}$ & 113372 \\
\hline $\begin{array}{l}1812 . \\
\text { Town ..... } \\
\text { Country ... } \\
\text { Scotland ... } \\
\text { Ireland.... }\end{array}$ & $\begin{array}{c}6162 \\
\ldots \\
50\end{array}$ & $\begin{array}{c}1094783 \\
\ldots \\
59955 \\
\ldots\end{array}$ & $\begin{array}{l}34 \\
\ddot{.} \\
\ddot{*}\end{array}$ & \begin{tabular}{c}
91944 \\
\hdashline \\
301 \\
$\ldots$
\end{tabular} & $\begin{array}{ccc}8423 & 13 & 6 s \\
\cdots & \end{array}$ & $\begin{array}{l}\cdots \\
\cdots \\
\cdots\end{array}$ & $\bar{z}$ \\
\hline & 6212 & 1154738 & 34 & 92245 & $\begin{array}{lll}8423 & 13 & 6 \frac{3}{4}\end{array}$ & .. & 93314 \\
\hline $\begin{array}{l}1813 . \\
\text { Town ...... } \\
\text { Country ... } \\
\text { Scotland ... } \\
\text { Ireland .... }\end{array}$ & $\begin{array}{c}5850 \\
\dddot{41} \\
\cdots\end{array}$ & $\begin{array}{c}932553 \\
\ldots \\
57670 \\
\ldots\end{array}$ & $\begin{array}{l}34 \\
\cdots \\
\cdots \\
\cdots\end{array}$ & $\begin{array}{c}49809 \\
\cdots \\
525 \\
\cdots\end{array}$ & $\begin{array}{ccc}7740 & 3 & 4 \frac{1}{2} \\
\cdots & \end{array}$ & $\begin{array}{c}{ }^{\circ} 7 \\
\cdots \\
\cdots\end{array}$ & $\bar{Z}$ \\
\hline & 5891 & 990223 & 34 & 50334 & $\begin{array}{lll}7740 & 3 & 4 \frac{1}{2}\end{array}$ & 776 & 115902 \\
\hline $\begin{array}{l}1814 . \\
\text { Town ...... } \\
\text { Country ... } \\
\text { Scotland ... } \\
\text { Ireland .... }\end{array}$ & $\begin{array}{c}6068 \\
\cdots \\
47 \\
. \\
\end{array}$ & $\begin{array}{c}863487 \\
\ddot{54210} \\
\ldots\end{array}$ & $\begin{array}{l}19 \\
\cdots \\
\cdots\end{array}$ & $\begin{array}{c}51877 \\
\cdots \\
357 \\
\cdots\end{array}$ & $\begin{array}{c}7375 \text { il } \\
\cdots \\
\cdots\end{array}$ & $\begin{array}{c}23 \ddot{10} 0 \\
\therefore\end{array}$ & $\overline{\bar{I}}$ \\
\hline & 6115 & 917697 & 19 & 52234 & $\begin{array}{lll}7375 & 11 & 3 \frac{1}{2}\end{array}$ & $2310 \quad 0$ & 127700 \\
\hline $\begin{array}{l}1815 . \\
\text { Town..... } \\
\text { Country ... } \\
\text { Scotland ... } \\
\text { Ireland .... }\end{array}$ & $\begin{array}{c}6731 \\
\ddot{48} \\
\cdots\end{array}$ & $\begin{array}{c}912310 \\
\ddot{61935} \\
\cdots \\
\end{array}$ & $\begin{array}{l}29 \\
\cdots \\
\cdots\end{array}$ & $\begin{array}{c}55581 \\
\cdots \\
367 \\
\ldots\end{array}$ & $\begin{array}{ccc}8544 & 10 & 5 \frac{1}{2} \\
\cdots & \end{array}$ & $\begin{array}{ccc}28 & 2 & 6 \\
\cdots & \end{array}$ & $\bar{z}$ \\
\hline & 6779 & 974245 & 29 & 55948 & $8544 \quad 10 \quad 5 \frac{1}{2}$ & $\begin{array}{lll}28 & 2 & 6\end{array}$ & 113240 \\
\hline $\begin{array}{l}\quad 1816 . \\
\text { Town ..... } \\
\text { Country ... } \\
\text { Scotland ... } \\
\text { Ireland . . . }\end{array}$ & $\begin{array}{c}7425 \\
\cdots \\
67 \\
\cdots \\
\end{array}$ & $\begin{array}{c}991010 \\
\ldots \\
63648 \\
. .\end{array}$ & $\begin{array}{l}495 \\
\cdots \\
\cdots \\
\cdots\end{array}$ & $\begin{array}{c}107016 \\
\dddot{1158} \\
\ldots\end{array}$ & $\begin{array}{ccc}9643 & 7 & 6_{\frac{\pi}{2}} \\
\cdots & & \end{array}$ & $\begin{array}{l}\ddot{ } \\
\ddot{*} \\
\cdots\end{array}$ & $\overline{\bar{z}}$ \\
\hline & 7492 & 1054658 & 495 & 108174 & $9643 \quad 7 \quad 6 \frac{x}{2}$ & - & 90650 \\
\hline
\end{tabular}




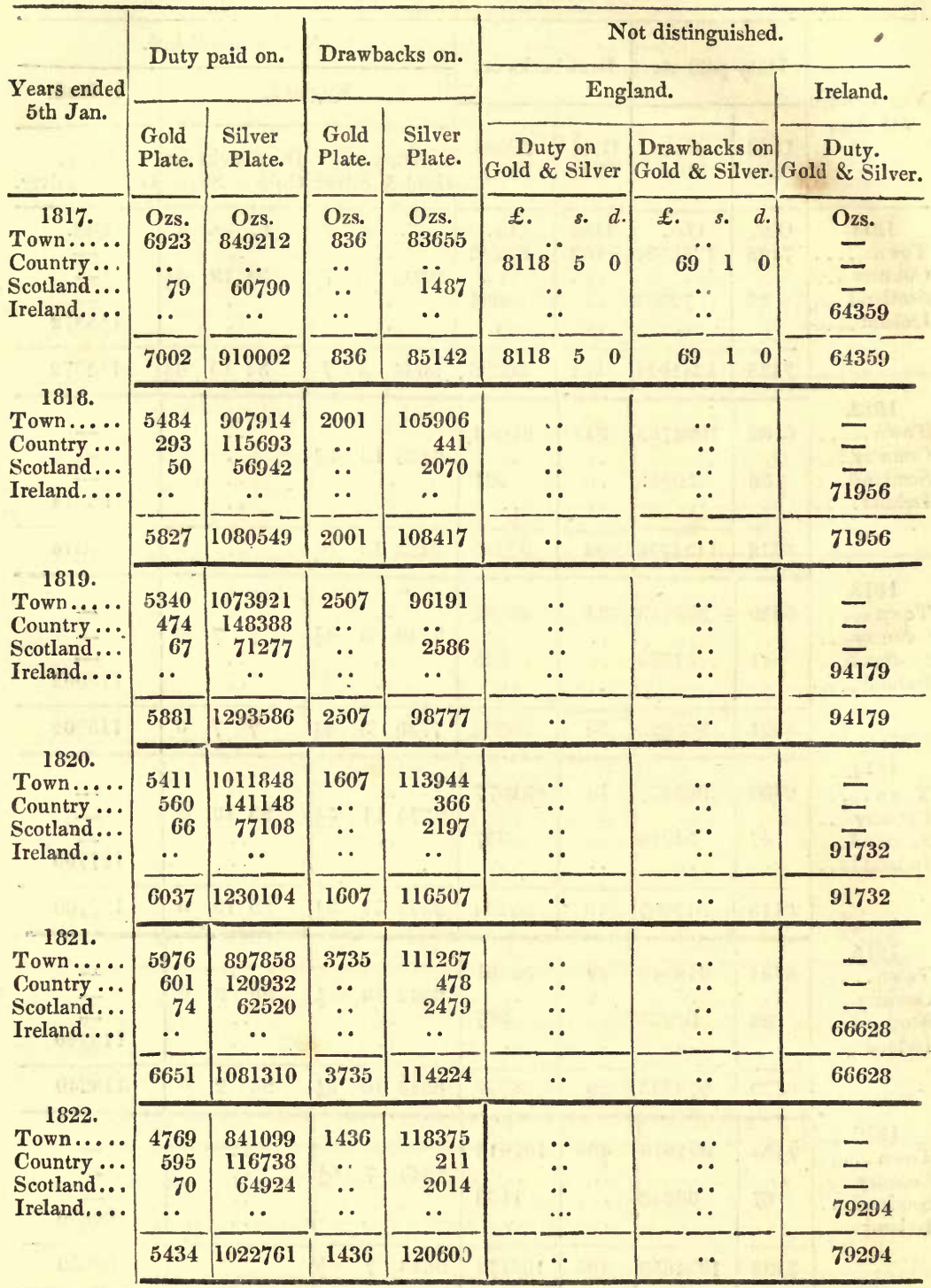




\begin{tabular}{|c|c|c|c|c|c|c|c|}
\hline \multirow{3}{*}{$\begin{array}{l}\text { Years ended } \\
5 \text { th Jan. }\end{array}$} & \multirow{2}{*}{\multicolumn{2}{|c|}{ Duty paid on. }} & \multirow{2}{*}{\multicolumn{2}{|c|}{ Drawbacks on. }} & \multicolumn{3}{|c|}{ Not distinguished. } \\
\hline & & & & & \multicolumn{2}{|c|}{ England. } & \multirow{2}{*}{$\frac{\text { Ireland. }}{\text { Duty. }}$} \\
\hline & $\begin{array}{l}\text { Gold } \\
\text { Plate. }\end{array}$ & $\begin{array}{l}\text { Silver } \\
\text { Plate. }\end{array}$ & $\begin{array}{l}\text { Gold } \\
\text { Plate. }\end{array}$ & $\begin{array}{l}\text { Silver } \\
\text { Plate. }\end{array}$ & $\begin{array}{c}\text { Duty on } \\
\text { Gold \& Silver. }\end{array}$ & \begin{tabular}{|l|} 
Drawbacks on \\
Gold \& Silver.
\end{tabular} & \\
\hline $\begin{array}{l}1823 . \\
\text { Town...... } \\
\text { Country ... } \\
\text { Scotland... } \\
\text { Ireland.... }\end{array}$ & $\begin{array}{c}\text { Ozs. } \\
6287 \\
651 \\
59 \\
\cdots\end{array}$ & $\begin{array}{c}\text { Ozs. } \\
854040 \\
113426 \\
60256 \\
\ldots\end{array}$ & $\begin{array}{c}\text { Ozs. } \\
1370 \\
\ldots \\
\ldots \\
\cdots\end{array}$ & $\begin{array}{c}\text { Ozs. } \\
63054 \\
1000 \\
729 \\
\cdots\end{array}$ & $\begin{array}{ccc}\text { E. } & & \text { s. } \\
\ldots & d . \\
\ldots & & \\
\ldots & & \\
\ldots & & \end{array}$ & $\begin{array}{cccc}\text { f. } & & s_{0} & d . \\
& \ldots & \\
& \ldots & \\
& \ldots & & \\
& & \end{array}$ & $\begin{array}{c}\text { Ozs. } \\
\overline{-} \\
\overline{84780}\end{array}$ \\
\hline & 6997 & 1027722 & 1370 & 64783 & $\cdots$ & $\cdots$ & 84780 \\
\hline $\begin{array}{l}\text { 1824. } \\
\text { Town...... } \\
\text { Country ... } \\
\text { Scotland... } \\
\text { Ireland.... }\end{array}$ & $\begin{array}{r}5871 \\
578 \\
67 \\
\cdots \\
\end{array}$ & $\begin{array}{c}895301 \\
115559 \\
62384 \\
\ldots\end{array}$ & $\begin{array}{l}20 \\
\cdots \\
\cdots \\
\ddot{*}\end{array}$ & $\begin{array}{c}93840 \\
1988 \\
1188 \\
. .\end{array}$ & $\begin{array}{l}\cdots \\
\cdots \\
\cdots\end{array}$ & 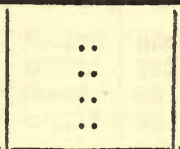 & $\bar{z}$ \\
\hline & 6516 & 1073244 & 20 & 97016 & .. & .. & 86568 \\
\hline $\begin{array}{l}\text { 1825. } \\
\text { Town...... } \\
\text { Country ... } \\
\text { Scotland... } \\
\text { Ireland.... }\end{array}$ & $\begin{array}{c}6865 \\
717 \\
80 \\
\cdots \\
\end{array}$ & \begin{tabular}{|}
1036669 \\
143335 \\
78654 \\
$\cdots$
\end{tabular} & $\begin{array}{l}38 \\
\ldots \\
\ldots \\
\cdots\end{array}$ & $\begin{array}{r}69360 \\
126 \\
996 \\
\cdots \quad\end{array}$ & $\begin{array}{l}\ddot{ } \\
\ddot{*} \\
\ddot{ }\end{array}$ & $\begin{array}{l}\ddot{ } \\
\ddot{0} \\
\ddot{ }\end{array}$ & $\bar{z}$ \\
\hline & 7662 & 1258658 & 38 & 70482 & - & .. & 99138 \\
\hline \begin{tabular}{l}
\multicolumn{1}{c}{1826.} \\
Town...... \\
Country ... \\
Scotland.... \\
Ireland, Y \\
from 5th \\
July,1825
\end{tabular} & $\begin{array}{r}7385 \\
930 \\
61 \\
110\end{array}$ & $\begin{array}{r}1240358 \\
177612 \\
48480 \\
\\
118804\end{array}$ & $\begin{array}{l}81 \\
\cdots \\
\cdots \\
\cdots\end{array}$ & $\begin{array}{r}108337 \\
1400 \\
2280 \\
\ldots\end{array}$ & $\begin{array}{l}\cdots \\
\cdots \\
\cdots\end{array}$ & $\begin{array}{l}\ddot{0} \\
\ddot{*} \\
\cdots\end{array}$ & E \\
\hline & 8486 & 1585254 & 81 & 112017 & $\cdots$ & .. & - \\
\hline $\begin{array}{c}1827 . \\
\text { Town..... } \\
\text { Country ... } \\
\text { Scotland... } \\
\text { Ireland.... }\end{array}$ & $\begin{array}{r}5890 \\
910 \\
92 \\
216\end{array}$ & $\begin{array}{r}934441 \\
135581 \\
74973 \\
102885\end{array}$ & $\begin{array}{l}\ddot{0} \\
\ddot{0} \\
\ddot{0}\end{array}$ & $\begin{array}{c}68352 \\
1840 \\
1301 \\
\cdots\end{array}$ & $\begin{array}{l}\ddot{ } \\
\ddot{0}\end{array}$ & 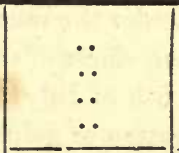 & $=$ \\
\hline & 7108 & 1247880 & -. & 71493 & . & $\cdots$ & - \\
\hline $\begin{array}{l}\text { 1828. } \\
\text { Town...... } \\
\text { Country ... } \\
\text { Scotland ... } \\
\text { Ireland.... }\end{array}$ & $\begin{array}{r}6162 \\
903 \\
47 \\
154 \\
\end{array}$ & $\begin{array}{r}920397 \\
124872 \\
58788 \\
103830\end{array}$ & $\begin{array}{l}10 \\
\cdots \\
\cdots \\
\cdots\end{array}$ & $\begin{array}{r}57809 \\
868 \\
2233 \\
. . \\
\end{array}$ & $\begin{array}{l}\ddot{0} \\
\ddot{0}\end{array}$ & $\begin{array}{l}\ddot{0} \\
\ddot{*} \\
\ddot{ }\end{array}$ & $=$ \\
\hline & 7266 & 1207887 & 10 & 60910 & $\cdots$ & . & - \\
\hline
\end{tabular}




\begin{tabular}{|c|c|c|c|c|c|c|c|}
\hline \multirow{3}{*}{$\begin{array}{l}\text { Years ended } \\
5 \text { th Jan. }\end{array}$} & \multirow{2}{*}{\multicolumn{2}{|c|}{ Duty paid on. }} & \multirow{2}{*}{\multicolumn{2}{|c|}{ Drawbacks on. }} & \multicolumn{3}{|c|}{ Not distinguished. } \\
\hline & & & & & Engl & land. & Ireland. \\
\hline & $\begin{array}{l}\text { Gold } \\
\text { Plate. }\end{array}$ & $\begin{array}{l}\text { Silver } \\
\text { Plate. }\end{array}$ & $\begin{array}{l}\text { Gold } \\
\text { Plate. }\end{array}$ & $\begin{array}{l}\text { Silver } \\
\text { Plate. }\end{array}$ & $\begin{array}{c}\text { Duty on } \\
\text { Gold \& Silver }\end{array}$ & $\begin{array}{l}\text { Drawbacks on } \\
\text { Gold \& Silver. }\end{array}$ & $\begin{array}{l}\text { Duty. } \\
\text { Gold \& Silver. }\end{array}$ \\
\hline $\begin{array}{l}1829 . \\
\text { Town ...... } \\
\text { Country ... } \\
\text { Scotland... } \\
\text { Ireland.... }\end{array}$ & $\begin{array}{r}\text { Ozs. } \\
5902 \\
1060 \\
61 \\
83 \\
\end{array}$ & \begin{tabular}{|c} 
Ozs. \\
1039265 \\
138220 \\
62352 \\
121495
\end{tabular} & $\begin{array}{c}\text { Ozs. } \\
\mathbf{2} \\
\cdots \\
\cdots \\
\cdots\end{array}$ & $\begin{array}{l}\text { Ozs. } \\
84360 \\
\text { ï97 } \\
\cdots\end{array}$ & $\begin{array}{ccc}\text { E. } & & \text { s. } \\
\ldots & \\
\ldots & \\
\ldots & \\
\ldots & \end{array}$ & 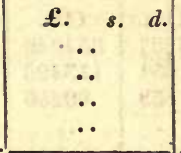 & $\frac{\text { Ozs. }}{-}$ \\
\hline Ireland.... & 7106 & 1361332 & 2 & 86157 & .. & .. & - \\
\hline $\begin{array}{l}1830 . \\
\text { Town ..... } \\
\text { Country... } \\
\text { Scotland... } \\
\text { Ireland.... }\end{array}$ & $\begin{array}{r}5458 \\
827 \\
68 \\
88\end{array}$ & $\begin{array}{r}965364 \\
132900 \\
59498 \\
113560\end{array}$ & $\begin{array}{l}12 \\
\cdots \\
\cdots \\
\cdots\end{array}$ & $\begin{array}{r}105817 \\
845 \\
3245 \\
\ldots\end{array}$ & $\begin{array}{l}\ddot{ } \\
\cdots \\
\cdots \\
\end{array}$ & $\begin{array}{l}\therefore \\
\therefore \\
\therefore\end{array}$ & - \\
\hline Ireland.... & 6441 & 1271322 & 12 & 109907 & . & .. & - \\
\hline
\end{tabular}

Note.-The number of ounces of gold plate and of silver plate on which duty was paid in Great Britain for the year ending the 5th of January, 1800, cannot be given, no distinction of gold and silver plate having been made in the office books; neither has there been any distinction made of the duties on gold and silver plate for the country till the year ending the 5th of January, 1818 , the country assay offices not having rendered in their accounts of the total quantity of gold and silver assayed separately. The product of the duty on plate has, therefore, in these instances been given.

With respect to Ireland, the Comptroller of Accounts there has attached the following notes to his account:-

" The duties on plate from the 5 th of January, 1799, to the 11th of August, 1807, were under the management of the Commissioners of Excise, and were collected by an officer of that branch of the revenue. From the 11 th of August, 1807 , to the 5th of July, 1825, the duties on plate were collected by an officer of the corporation of goldsmiths, from whose books the account for that period is prepared ; but the number of ounces of gold and silver can only be separately set forth from the 5th of July, 1825, at which time the duties were transferred to the management of the Commissioners of Stamps.

" No drawbacks are allowed by law on plate wrought in Ireland."

Accompt. and Compt.-General's Office,

Stamps,

S. R. BARKER, Pro. A. and C. G.

9th September, 1830. 


\section{No. 14.}

Imports and Exports of Treasure-India and China.

An account showing the amount of bullion imported into Bengal, Madras, and Bombay, from the United Kingdom, Foreign Europe, and North and South America, including the amount imported into China on account of the East India company, and the Americans; together with the amount exported from Bengal, Madras, and Bombay, to the United Kingdom, \&c., in the following years.

\begin{tabular}{|c|c|c|c|c|}
\hline & $\begin{array}{c}\text { Amount bullion } \\
\text { imported } \\
\text { into lndia and } \\
\text { China. }\end{array}$ & $\begin{array}{c}\text { A mount bullion } \\
\text { exported } \\
\text { from India and } \\
\text { China. }\end{array}$ & $\begin{array}{c}\text { Excess } \\
\text { Imports. }\end{array}$ & $\begin{array}{c}\text { Excess } \\
\text { Exports. }\end{array}$ \\
\hline $1810-11$ & $\begin{array}{l}\text { Rupees. } \\
50.60844\end{array}$ & Rupees. & $\begin{array}{l}\text { Rupees. } \\
30060344\end{array}$ & Rupees. \\
\hline $1811-12$ & $88,65,264$ & $98,44,701$ & & $9,79,437$ \\
\hline $1812-13$ & $40,01,242$ & $67,44,278$ & & $27,43,036$ \\
\hline $1813-14$ & $2,99,696$ & 9739,481 & & $94,39,785$ \\
\hline $1814-15$ & $79,36,422$ & $32,62,204$ & $46,74,218$ & \\
\hline $1815-16$ & $2,37,52,240$ & 14,613 & $2,37,37,627$ & \\
\hline $1816-17$ & $3,09,85,676$ & 29,163 & $3,09,56,513$ & \\
\hline $1817-18$ & $3,52,37,628$ & & $3 ; 52,37,628$ & \\
\hline $1818-19$ & $6,42,52,998$ & 6,630 & $6,42,46,368$ & \\
\hline $1819-20$ & $3,82,42,386$ & 11,250 & $3,82,31,136$ & \\
\hline $1820-21$ & $* 1,09,91,011$ & 81,806 & $1,09,09,205$ & \\
\hline $1821-22$ & $2,43,38,439$ & $3,42,722$ & $2,39,95,717$ & \\
\hline $1822-23$ & $2,36,91,308$ & $1,63,35,186$ & $73,56,122$ & \\
\hline $1823-24$ & $1,43,53,136$ & $\quad 17,98,022$ & $1,25,55,114$ & \\
\hline $1824-25$ & $1,96,51,591$ & $1,09,14,675$ & $87,36,916$ & \\
\hline $1825-26$ & $1,78,34,794$ & 94,048 & $1,77,40,746$ & \\
\hline $1826-27$ & $72,19,988$ & $11,15,802$ & $61,04,186$ & \\
\hline $1827-28$ & $98,24,719$ & $19,92,884$ & $78,31,835$ & \\
\hline \multirow[t]{2}{*}{ 1828-29 } & $38,91,618$ & $96,62,218$ & & $57,70,600$ \\
\hline & & & & \\
\hline
\end{tabular}

* The American imports into China are not included in this sum, the value of the American trade for this year not being stated in the accounts received from China. 


\section{No. 15.}

\section{Russian Trade with Asiatic Nations.}

Extract translated from the Journal du Commerce of St. Petersburgh of the 10th of April, 1831.

Operations of the commerce which passed through the custom-houses of the circle of Astrachan during the year 1820. - The position of Astrachan, near the Caspian Sea and not far from the mouth of the Volga, the greatest river in Russia, which forms a communication between the two capitals, as well as with the most fertile provinces of the empire and with the fair of Nijny-Novgord, has made it for a long time the central point of the commerce with the neighbouring nations of Asia.

Persia, Khiva, and Bucharia supply us with raw materials which are absolutely necessary for the fabrication of the goods which find a ready sale in those countries. In the course of the last year the operations through the custom-houses of the circle of Astrachan were less extensive than in 1829, on account of the prevalence of cholera morbus, which had ravaged the countries where that commerce is most considerable, and opposed obstacles as well to the importation as to the exportation, at that time of the year when both are usually the most brisk.

Exportations.

The custom-house at Astrachan at Bakou at Kizlar
1830.

\begin{tabular}{rr}
$3,560,639$ & $4,422,340$ \\
386,527 & $1,028,660$ \\
793,599 & $\mathbf{7 5 6 , 9 4 4}$ \\
\hline $4,740,765$ & $6,207,944$
\end{tabular}

roubles $4,740,765 \quad 6,207,944$

Importations.

The custom-house at Astrachan

at Bakou

at Kizlar

The barrier at Kouba

at Derbent

\begin{tabular}{rr}
$2,804,368$ & $3,337,790$ \\
$1,997,113$ & $2,184,668$ \\
10,611 & 8,635 \\
1,618 & 25,960 \\
1,584 & 26,856 \\
\hline $4,815,294$ & $5,583,909$
\end{tabular}

roubles $4,815,294$ 
Operations of the commerce which passed through the custom-houses of the circle of Siberia in 1830. - The trade on the Siberian frontier fills an important space in the whole field of our exterior commercial relations, and its progress is deserving of attention on account of its great influence on our domestic industry. Notwithstanding the small number of Russian merchants that are engaged in it, and the thinness of the population near the frontier, with the vicinity of the Thirghises who separate us from the states of Asia and prevent a rapid developement, there has been annually, on the whole, an increase. Our woollen goods, our cottons, our silks, and our wrought metals of different kinds, find advantageous sales on that side. The skins of the cattle which the Asiatics supply to us are converted into leather, and returned again with a profit. In exchange for our various commodities we receive Chinese silver, cattle, furs, which are sent into China, cotton, wool, camel's hair, down of rabbits, as well as some articles of cotton and silk of Asiatic fabrication. The operations at the custom-houses have been as follow:-

\begin{tabular}{|c|c|c|}
\hline \multirow{2}{*}{ Importations. } & 1829. & 1830. \\
\hline & Roubles. & $\begin{array}{l}\text { Roubles. } \\
1,453,624\end{array}$ \\
\hline \multirow{2}{*}{$\begin{array}{r}\text { Custom-house at Petropaulousk } \\
\text { at Semipalatinsk }\end{array}$} & 430,344 & 343,901 \\
\hline & $1,402,900$ & $1,807,525$ \\
\hline \multirow{4}{*}{$\begin{array}{r}\text { Exportations. } \\
\text { Custom-house at Petropaulousk } \\
\text { at Semipalatinsk }\end{array}$} & & \\
\hline & 967,822 & $1,150,254$ \\
\hline & 570,803 & 505,233 \\
\hline & $1,537,625$ & $1,655,487$ \\
\hline
\end{tabular}

Besides this there was imported at Petropaulousk, in 1829, 4 poods $25 \frac{1}{2}$ pounds of China silver; and in 1830, 6 poods 29 pounds; and at Semipalatinsk, 155 poods in 1829, and 166 poods in 1830 .

"Moscow, March 31, 1831.

"The fair of Irbit ${ }^{1}$ this year is said by the traders who have returned from thence to have been more beneficial than

1 Irbit is a town on the river of the same name, in the Russian governinent 
in former years, and that goods in general have been sold on better terms than was expected. Some articles, such as tea, white cottons, cloth of all kinds, printed calicoes of Moscow, nankeens, furs, and silks of a medium quality, have been disposed of readily, and at profitable prices.

"The Boukarians and the Taschkenes brought to Irbit about 175 poods of silver in ingots, of which about 100 poods have been received in payment by the traders of Moscow. It is asserted that so many goods have never been brought to this fair."-Gaz. du Commerce.

Commerce of Teflis.- " In the course of the year 1830, the amount of the transactions on which duties have been paid at the custom-house of this place was, importation, 6,794,648 roubles ; and exportation, $1,659,852$. In the preceding year the importations had amounted to 5,133,990 roubles, and the exportations to 2,525,659 roubles."-Journal du Commerce.

of Perm, on the frontiers of Siberia, where a fair is held in January (the season for travelling on the ice), which is frequented, not only by the Russians and Siberians, but by Tartars, Armenians, and others. It is in north latitude $57^{\circ} 35^{\prime}$, longitude $62^{\circ} 50^{\prime}$ east. 
No. $16, A$.

An account showing the number of silver and gold watch-cases assayed at Goldsmith's Hall, London.

\begin{tabular}{rrr} 
Year. & \multicolumn{1}{c}{ Silver. } & Gold. \\
1810 & 152,587 & 17,257 \\
1811 & 130,246 & 12,579 \\
1812 & 124,088 & 12,921 \\
1813 & 113,177 & 13,974 \\
1814 & 133,776 & 13,943 \\
1815 & 121,725 & 12,544 \\
1816 & 91,346 & 10,766 \\
1817 & 79,123 & 14,457 \\
1818 & 117,994 & 18,317 \\
1819 & 88,731 & 15,161 \\
1820 & 80,144 & 12,940 \\
1821 & 77,727 & 12,102 \\
1822 & 70,869 & 12,670 \\
1823 & 69,542 & 13,210 \\
1824 & 81,112 & 14,776 \\
1825 & 102,645 & 17,769 \\
1826 & 86,197 & 10,611 \\
1827 & 82,207 & 13,196 \\
1828 & 88,741 & 14,779 \\
1829 & 83,484 & 13,706
\end{tabular}


No. $16, \mathrm{~B}$.

Gold and silver watches assayed in Dublin.

$\begin{array}{ccc}\text { Year. } & \text { Silver. } & \text { Gold. } \\ 1810 & 355 & 101 \\ 1811 & 414 & 128 \\ 1812 & 380 & 114 \\ 1813 & 361 & 108 \\ 1814 & 333 & 91 \\ 1815 & 342 & 73 \\ 1816 & 304 & 92 \\ 1817 & 322 & 95 \\ 1818 & 290 & 78 \\ 1819 & 231 & 53 \\ 1820 & 280 & 64 \\ 1821 & 225 & 63 \\ 1822 & 211 & 57 \\ 1823 & 301 & 79 \\ 1824 & 203 & 42 \\ 1825 & 247 & 39 \\ 1826 & 251 & 53 \\ 1827 & 217 & 59 \\ 1828 & 75 & 25 \\ 1829 & 60 & 20\end{array}$




\section{No. 16 , C.}

An account showing the weight of watch-cases assayed at Chester, from 1814 to 1829 , inclusive.

$\begin{array}{ccc}\text { Year. } & \begin{array}{c}\text { Silver. } \\ \text { ozs. }\end{array} & \begin{array}{c}\text { Gold. } \\ \text { ozs. }\end{array} \\ 1814 & 1741 \frac{1}{2} & 2858 \\ 1815 & 2477 & 3028 \\ 1816 & 2048 & 2476 \\ 1817 & 2183 & 2215 \\ 1818 & 3060 & 2705 \\ 1819 & 2036 & 3173 \\ 1820 & 1588 & 3278 \\ 1821 & 1921 & 3573 \\ 1822 & 2271 & 4923 \\ 1823 & 2619 & 5925 \\ 1824 & 2196 & 5985 \\ 1825 & 3029 & 6974 \\ 1826 & 1744 & 5568 \\ 1827 & 1820 & 6447 \\ 1828 & 1890 & 7476 \\ 1829 & 1520 & 6139\end{array}$

The account at Chester was not kept with regularity before the year 1814. At Sheffield the whole number of silver watches assayed did not in the ten years exceed one hundred and ten, and none of gold were assayed. At Exeter only seven silver watches were assayed; none at York or Newcastle; and at Glasgow and Edinburgh no accounts are kept. 
By the same Author,

\section{T R A C T S \\ oN}

\section{SUBJECTS CONNECTED WITH THE CORN TRADE AND CORN LAWS.}

One vol. octavo.

LONDON :

PRINTED BY THOMAS DAVISON, WHITEFRIAR. 



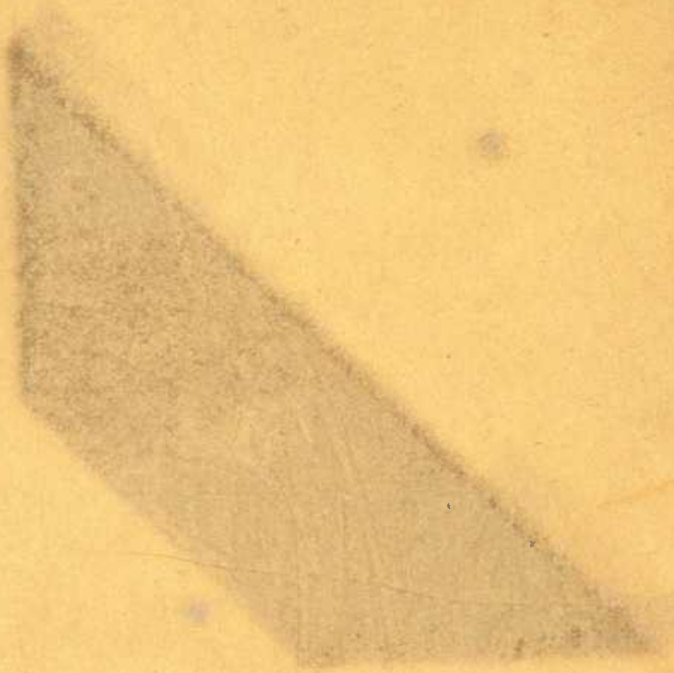




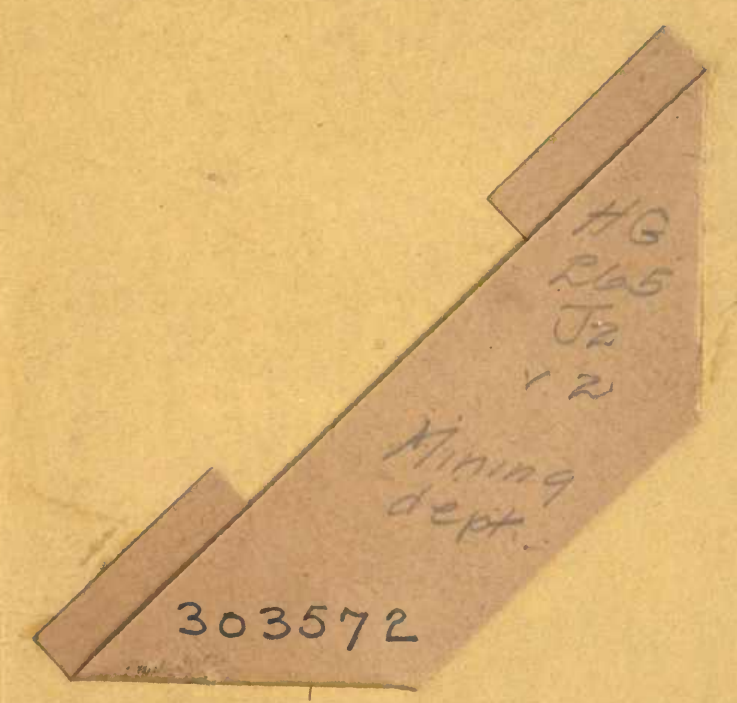




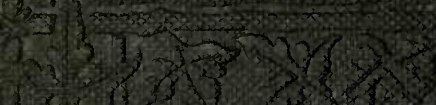

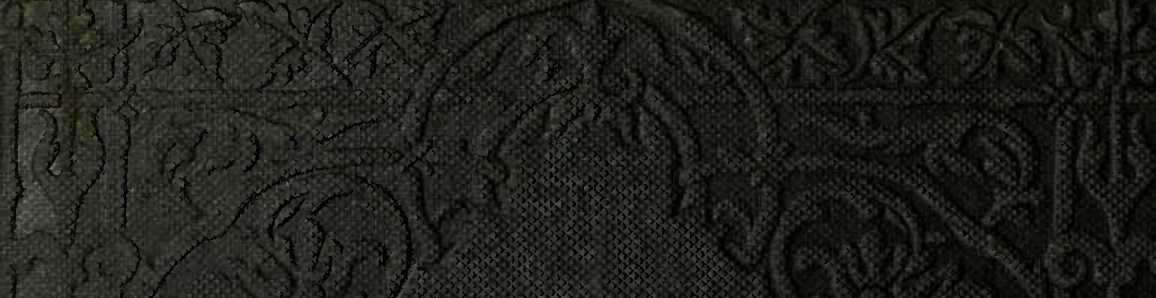

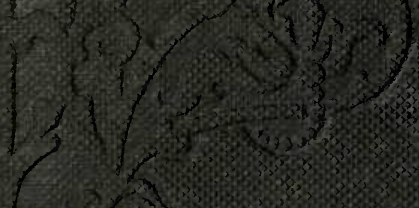

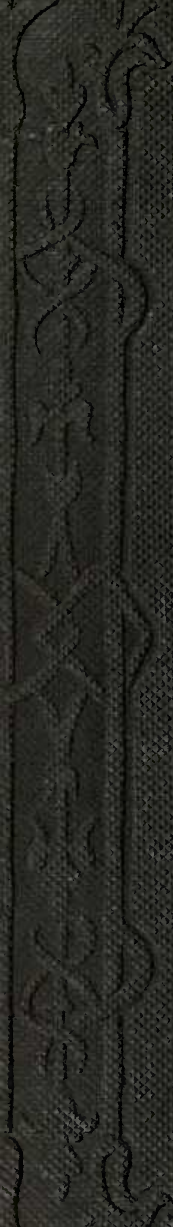

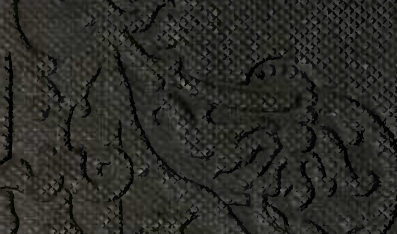

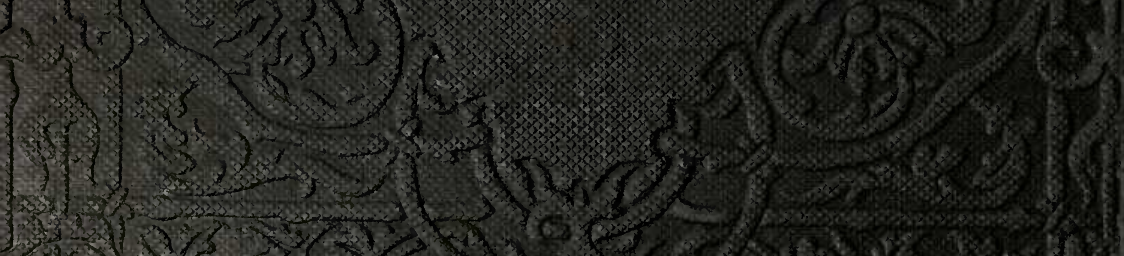

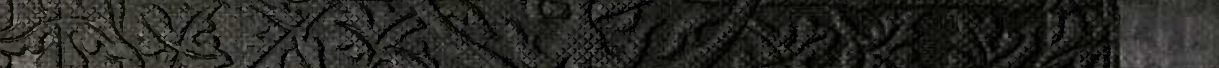

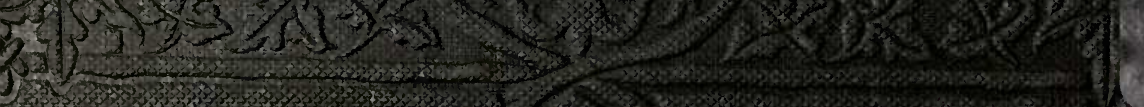

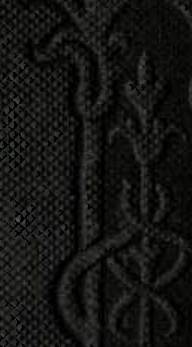

$z^{2} z^{2}+1$

9)

(8)

$5+3$

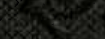

산

7

18

S9

(5)

$\sin 4 x-5$ 